CENTRO UNIVERSITÁRIO FEI

DENISE BORSOS BAIÃO

AVALIAÇÃO COMPORTAMENTAL DE PRÉ-MISTURAS FARMACÊUTICAS E SUAS POSSÍVEIS INFLUÊNCIAS NO PROCESSO PRODUTIVO

São Bernardo do Campo 

DENISE BORSOS BAIÃO

\section{AVALIAÇÃO COMPORTAMENTAL DE PRÉ-MISTURAS FARMACÊUTICAS E SUAS POSSÍVEIS INFLUÊNCIAS NO PROCESSO PRODUTIVO}

Dissertação apresentado ao Centro Universitário FEI, como parte dos requisitos necessários para obtenção do título de Mestre em Engenharia Química. Orientado pelo Prof. Dr. Rodrigo Condotta.

São Bernardo do Campo 
Borsos Baião, Denise.

Avaliação comportamental de pré-misturas farmacêuticas e suas possíveis influências no processo produtivo / Denise Borsos Baião. São Bernardo do Campo, 2018.

158 p. : il

Dissertação - Centro Universitário FEI.

Orientador: Prof. Dr. Rodrigo Condotta.

1. Produção de Medicamentos. 2. Scale up. 3. Efavirenz. 4. Facilitador de Fluxo. 5. Efeito Capping. I. Condotta, Rodrigo, orient. II Titulo.

Elaborada pelo sistema de geração automática de ficha catalográfica da FEI com os dados formecidos pelo(a) autor(a). 
Título do Trabalho: Avaliação comportamental de pré-misturas farmacêuticas e suas possiveis influências no processo produtivo.

Área de Concentração: Engenharia Química

Orientador: Prof. Dr. Rodrigo Condotta

Data da realização da defesa: 29/08/2018

\section{ORIGINAL ASSINADA}

Avaliação da Banca Examinadora:

São Bernardo do Campo,

MEMBROS DA BANCA EXAMINADORA

Prof. Dr. Rodrigo Condotta

Prof. Dr. Luis Fernando Novazzi

Prof. Dr. Newton Andréo Filho
Ass.:

Ass.:

Ass.:

A Banca Julgadora acima-assinada atribuiu ao aluno o seguinte resultado:

APROVADO $\square$

REPROVADO $\square$

\section{YERSÃO FINAL DA DISSERTACÃO}

APROVO A VERSÃO FINAL DA DISSERTAÇ̄̃O EM QUE FORAM INCLUIDDS AS RECOMENDACOOEES DA BANCA EXAMINADORA
Aprovaçäo do Coordenador do Programa de Pós-graduaçăo

Prof. Dr. Ricardo Belchior Torres 

Aos meus pais, ao meu noivo e ao meu irmão.

Dedico este trabalho. 



\section{AGRADECIMENTOS}

A realização desse objetivo só foi possível graças ao apoio de familiares e amigos que tornam a vida mais leve. Meu "muitíssimo obrigada"!

À minha mãe afável, exemplo de coragem e doação, pela compreensão e conselhos.

Ao meu pai, pelo incentivo aos estudos e dedicação à família.

Ao meu noivo Frederico, exemplo de disciplina, pela paciência, ajuda e amável convivência.

Ao meu irmão e amigo Felipe, pela confiança durante o desenvolvimento do trabalho.

Ao Prof. Dr. Rodrigo Condotta pelos ensinamentos, orientação, suporte e discussões que contribuíram para o meu aprendizado.

À todos os professores que me acompanharam durante minha formação, pela disponibilidade e por toda a ajuda.

Aos Técnicos e Funcionários dos laboratórios do CLQ e CLM, sempre dispostos a me ajudar.

Ao Centro Universitário FEI, pelo ambiente criativo e amigável, e pela oportunidade de realizar este trabalho. Muito obrigada!

À CAPES pela bolsa concedida ${ }^{1}$.

À empresa Farmanguinhos/ Fiocruz pela parceria por meio do fornecimento das amostras analisadas.

Aos meus sogros, Antônia e Francisco, pela amizade e pelo carinho.

Aos meus avós, pelo exemplo de carácter e bondade.

À todos que participaram direta e indiretamente no desenvolvimento deste trabalho.

E acima de tudo, à Deus por colocar pessoas tão especiais em minha vida e por me permitir alcançar mais essa conquista.

\footnotetext{
${ }^{1}$ O presente trabalho foi realizado com apoio da Coordenação de Aperfeiçoamento de Pessoal de Nível Superior - Brasil (CAPES) - Código de Financiamento 001.
} 

"It ain't what you don't know that gets you into trouble. It's what you know for sure that just ain't so."

Mark Twain. 



\section{RESUMO}

Materiais particulados de granulometria reduzida possuem propriedades específicas que dizem respeito à natureza das partículas, às características do meio e às condições impostas pelos equipamentos e que diferem do comportamento desses mesmos materiais de granulometria superior. Com isso, os sólidos à granel podem sofrer alterações em suas características durante o processamento e adquirir um comportamento imprevisível e incerto. A ausência de registro e acervo das principais causas e soluções para os problemas da indústria farmacêutica afeta negativamente o desenvolvimento e a produção de medicamentos, principalmente ao longo da etapa de scale up e após a compressão, comprometendo os aspectos físicos do produto final. No intuito de oferecer e registrar dados pertinentes de caracterizações quantitativas de insumos básicos comumente presentes nas formulações farmacêuticas, minimizar limitações de processo, resultar em melhorias no controle de qualidade, menos tempo de inatividade em operações unitárias e auxiliar o profissional desse segmento industrial, esse trabalho aferiu o comportamento e determinou propriedades estáticas e dinâmicas de pré-misturas da indústria farmacêutica, utilizadas principalmente na obtenção da função de fluxo desses materiais particulados. Na primeira etapa estudou-se o efeito do acréscimo do estearato de magnésio e do dióxido de silício em pré-misturas formuladas a partir de microcelulose 101 (MCC 101), microcelulose 102 (MCC 102), lactose monohidratada (LM) e lactose spray-dried (LSD). Dentre as amostras puras, foi constatado um comportamento menos coesivo para a LSD. Nas análises das pré-misturas, o dióxido de silício demonstrou ser o melhor facilitador de fluxo por diminuir a compressibilidade e a coesão e melhorar a permeabilidade e a aeração, o que pode resultar em uma melhor fluidização e menor tendência ao efeito capping. A segunda etapa teve por objetivo analisar as propriedades de fluxo de amostras formuladas com suspensões de Efavirenz e excipientes como lactose, dióxido de silício $\left(\mathrm{SIO}_{2}\right)$, croscamelose sódica (CMNa) e manitol. Verificou-se que para cada condição de análise há uma pré-mistura mais adequada, com destaque para a MCOLEFV 0614 por ser a mais indicada para transportes por pás e roscas e a MCOLEFV 0715 por apresentar a melhor permeabilidade, ou seja, por apresentar menor propensão em ter ar aprisionado entre suas partículas durante a etapa de compressão que possa expandir causando o efeito capping no produto final após o alívio da tensão aplicada.

Palavras Chaves: Produção de Medicamentos. Limitação de Processo. Scale up. Efavirenz. Fluidez. Facilitador de Fluxo. Efeito Capping. 



\begin{abstract}
Materials composed by small particles have specific properties which are related to the nature of the particles, the characteristics of the fluid present in the interstitial space between particles and to conditions imposed by equipments. This properties also differs from the behavior of higher particles size materials. Thus, bulk solids may undergo changes in their characteristics during processing resulting in unpredictable and uncertain behavior. The absence of data registration of the main causes and possible solutions for the pharmaceutical industry problems adversely affect development and production of drugs. These issues are often observed on scale up and compression process of tablets manufacture, which may also compromise the physical aspects of the final product. In order to provide considerable data from alternative quantitative methods of characterization, this work has investigated the behavior of premixtures used in the pharmaceutical industry. It is supposed that fully characterized mixtures could contribute to explain the causes of process limitation and improve quality control, and to assist the professional of this industrial segment. Tests were carried out in order to determine static and dynamic properties, mainly the flow function. In the first stage of this final paper, the addition of the magnesium stearate lubricant and silicon dioxide glidant was evaluated in premixtures formulated from the diluents micro cellulose 101 (MCC 101), microcellulose 102 (MCC 102), lactose monohydrate (LM) and lactose spray - dried (LSD). It was found a less cohesive behavior for LSD among the pure samples. In the premixtures analyzis, silicon dioxide proved to be the best facilitator flow by reducing compressibility and cohesion and improving permeability and aeration. This can result in better fluidization and less tendency to capping effect. The second step was to analyze the flow properties of samples formulated with suspensions of Efavirenz and excipients such as lactose, silicon dioxide (SIO2), croscamelosis sodium (CMNa) and mannitol. It has been found that for each analysis condition there is an ideal premixture. MCOLEFV 0614 is the ideal premix to be moved by blades and threads, and MCOLEFV 0715 is the best permeability sample because of its lower propensity to have trapped air between its particles during the compression stage. That can expand causing the capping effect on the final product after the relief of the applied voltage.
\end{abstract}

Keywords: Production of Drugs. Process Limitation. Scale up. Efavirenz. Fluidity. Flow Facilitator. Capping Effect. 



\section{LISTA DE ILUSTRAÇÕES}

Figura 1 - Principais forças atuando sobre as partículas de material não consolidado. ...........27

Figura 2- Representação do travamento mecânico entre duas partículas................................ 28

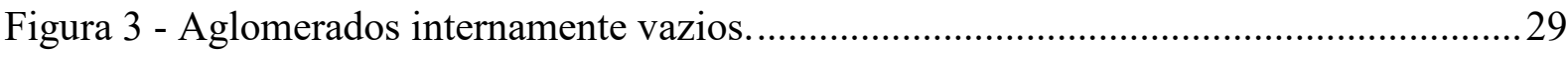

Figura 4 - Adição de uma nova partícula em um meio que já possui outras partículas. .......... 30

Figura 5 - Formação do leito de partículas de pequena granulometria. ....................................30

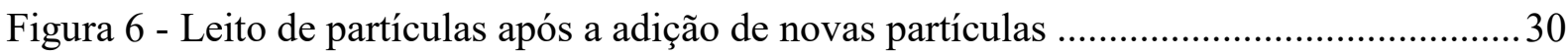

Figura 7 - Leito de partículas quando a ação da gravidade atuante na partícula é capaz de

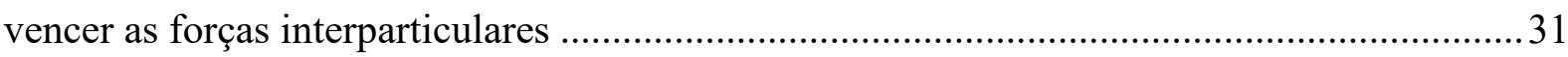

Figura 8 - Três fases do preenchimento dos poros de partículas grandes com partículas

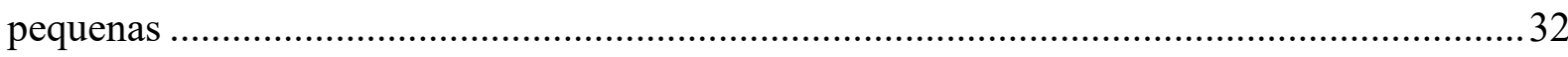

Figura 9 - Tipos de empacotamento com apenas uma partícula no interstício ........................ 33

Figura 10 - Relação entre o tamanho das partículas próximo de um .........................................33

Figura 11 - Lactose Monohidratada e Lactose Spray - Dried ................................................... 37

Figura 12 - Representação do processo produtivo................................................................ 42



Figura 14 - Fluidização de um material sensível à aeração...................................................52



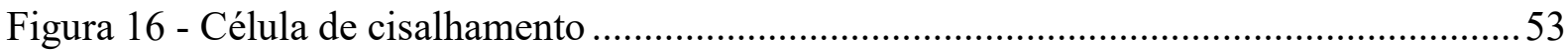

Figura 17 - Esquematização do teste de cisalhamento ............................................................55

Figura 18 - Locus de atrito e propriedades de fluxo....................................................................56

Figura 19 - Lugar geométrico de deslizamento e função de fluxo ..........................................56

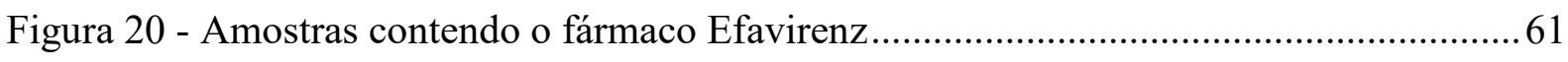

Figura 21 - Distribuição granulométrica das amostras puras precursoras das pré-misturas de

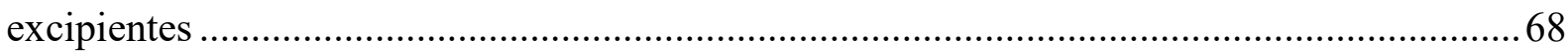

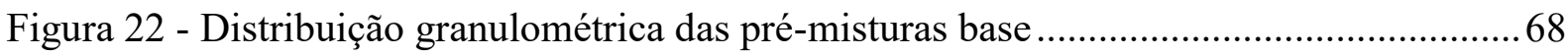

Figura 23 - Perfil de estabilidade e fluxo variável dos excipientes puros ................................ 72

Figura 24 - Perfil de estabilidade e fluxo variável dos excipientes puros e da mistura M1 com

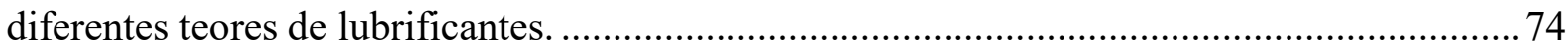

Figura 25 - Perfil de estabilidade e fluxo variável das pré-misturas $\mathrm{Mx}+1 \% \mathrm{Mag}$.................. 75

Figura 26 - Perfil de estabilidade e fluxo variável das pré-misturas $\mathrm{Mx}+\mathrm{zSiO} 2$.................... 76

Figura 27 - Adição conjunta de estearato de magnésio e de dióxido de silício.........................77 
Figura 28 - Perfil de Compressibilidade para as amostras puras precursoras das pré-misturas de excipientes

Figura 29 - Perfil de compressibilidade das amostras puras e das pré-misturas originadas a partir de M4

Figura 30- Perfil de Permeabilidade para as amostras puras precursoras das pré-misturas de excipientes

Figura 31 - Perfil de Permeabilidade da mistura M4 ....

Figura 32 - Perfil de Permeabilidade da mistura M9.

Figura 33 - Perfil de Aeração para as amostras puras precursoras das pré-misturas de excipientes

Figura 34 - Perfil de aeração das amostras puras e das pré-misturas originadas a partir de M10

Figura 35-Coesão à 3, 6, 9 e $15 \mathrm{kPa}$ para as amostras puras precursoras das pré-misturas de excipientes.

Figura 36 - Função de Fluxo das amostras puras precursoras das pré-misturas de excipientes

Figura 37 - Coesão das pré-misturas que têm como base M3 …........................................... 93

Figura 38 - Função de fluxo das pré-misturas que têm como base M3 .................................. 94

Figura 39 - Distribuição granulométrica das amostras que contêm o princípio ativo e do

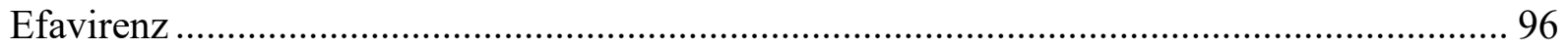

Figura 40 - Perfil de Estabilidade e Fluxo variável das amostras com Efavirenz .................. 99

Figura 41 - Teste de compressibilidade para as pré-misturas contendo Efavirenz................ 100

Figura 42 - Teste de permeabilidade para pré-misturas contendo Efavirenz.......................... 102

Figura 43 - Teste de aeração para amostras contendo Efavirenz ........................................... 104

Figura 44 - Teste de cisalhamento para amostras contendo Efavirenz ................................. 105

Figura 45 - Função de Fluxo das amostras contendo Efavirenz ........................................... 106 


\section{LISTA DE TABELAS}

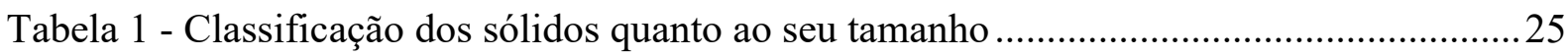

Tabela 2 - Etapas da produção de comprimidos com suas principais variáveis.......................45

Tabela 3 - Classificação da fluidez segundo o Índice de Estabilidade.....................................49

Tabela 4 - Classificação da fluidez segundo o Índice de Fluxo Variável..................................50

Tabela 5 - Classificação da compressibilidade........................................................................ 51



Tabela 7 - Classificação da razão de aeração. .......................................................................5

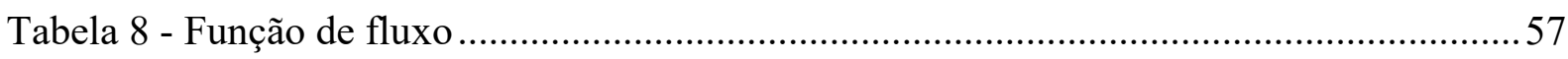

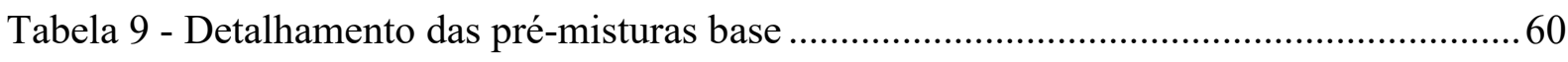

Tabela 10 - Detalhamento das amostras contendo princípio ativo......................................... 61

Tabela 11 - Área superficial das amostras puras precursoras das pré-misturas de excipientes 67

Tabela 12 - Diâmetro médio volumétrico das amostras puras e pré-misturas base 69

Tabela 13: Massa específica para as amostras puras precursoras das pré-misturas de excipientes

Tabela 14 - Massa específica para as pré-misturas de excipientes

Tabela 15 - Teste de Estabilidade e Fluxo variável para as amostras puras precursoras das pré-misturas de excipientes.

Tabela 16 - Teste de Estabilidade e Fluxo variável para pré-misturas que têm como base a mistura M1

Tabela 17 - Teste de Compressibilidade para as amostras puras precursoras das pré-misturas de excipientes

Tabela 18 - Teste de Compressibilidade para pré-misturas que têm como base M1, M3, M4 e M6.

Tabela 19 - Teste de Compressibilidade para pré-misturas que têm como base M7, M9, M10 e M12. 80

Tabela 20 - Teste de Permeabilidade para as amostras puras precursoras das pré-misturas de excipientes

Tabela 21 - Teste de Permeabilidade para pré-misturas base.

Tabela 22 - Teste de Aeração para as amostras puras precursoras das pré-misturas de excipientes 86

Tabela 23 - Energia de aeração para pré-misturas de excipientes 88

Tabela 24 - Relação de aeração para pré-misturas de excipientes 88 
Tabela 25 - Área superficial e composição das amostras com Efavirenz.

Tabela 26 - Diâmetro médio volumétrico das amostras que contêm o princípio ativo e do

Efavirenz 96

Tabela 27 - Massa específica das amostras que contêm o princípio ativo Efavirenz .............. 97

Tabela 28 - Teste de Estabilidade e Fluxo Variável .............................................................. 98

Tabela 29 - Resultados do teste de compressibilidade para pré-misturas contendo Efavirenz 100

Tabela 30 - Teste de Permeabilidade para as amostras contendo Efavirenz. 101

Tabela 31 - Resultados do teste de aeração para pré-misturas contendo Efavirenz 103 


\section{SUMÁRIO}

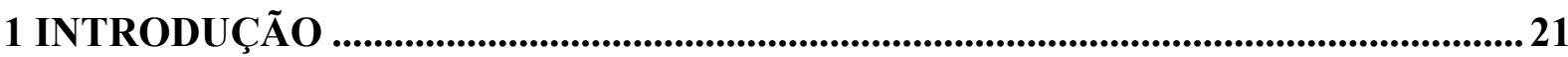

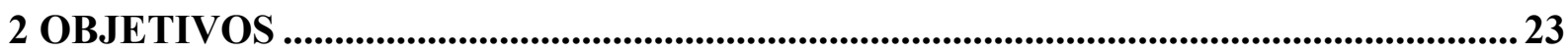

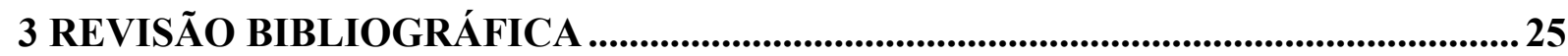

3.1 Sistemas Particulados: Uma breve apresentação de suas características .......................... 25

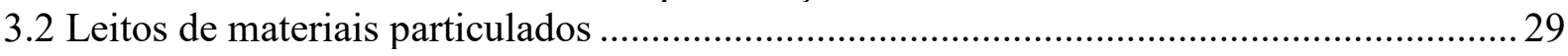

3.2.1 Leitos monodispersos constituídos de partículas de pequena granulometria .................29

3.2.2 Leitos monodispersos constituídos de partículas grandes .............................................. 31

3.2.3 Leitos dispersos constituídos de partículas de pequena granulometria e partículas grandes 32

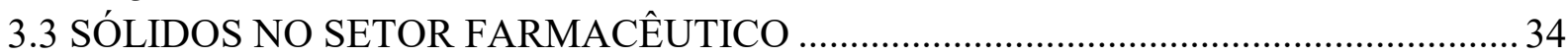

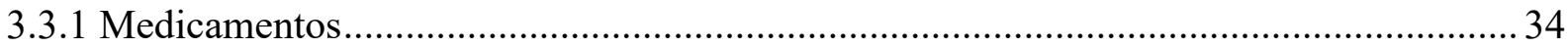

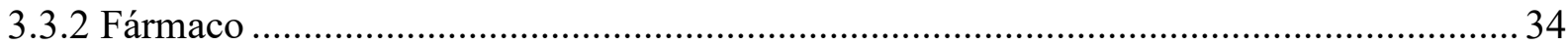

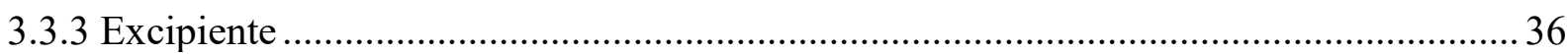

3.4 FASES DO DESENVOLVIMENTO DE PRODUTOS FARMACÊUTICOS ................... 41

3.5 ETAPAS DA PRODUÇÃO E PROBLEMAS NO PROCESSO DE FABRICAÇÃO DE



3.6 Propriedades físicas das partículas: conhecimento relacionado à Ciência e a Tecnologia dos

Pós 45

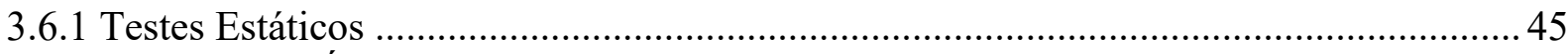

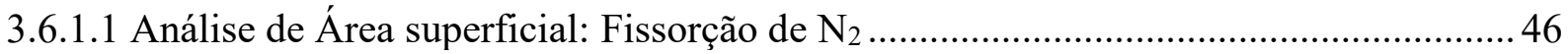



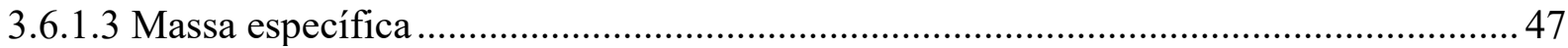

3.6.2 Testes Dinâmicos a partir do Reômetro de Pó FT-4. ...................................................... 48

3.6.2.1 Teste de Estabilidade e Fluxo Variável ....................................................................... 49



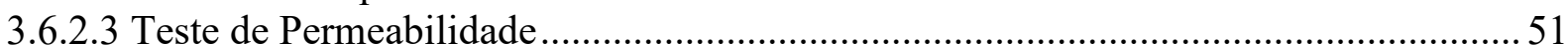

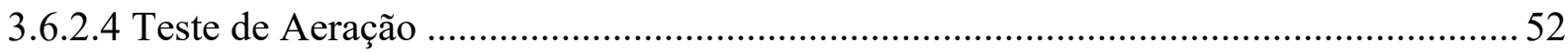



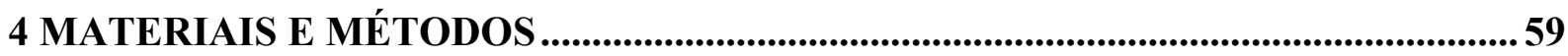



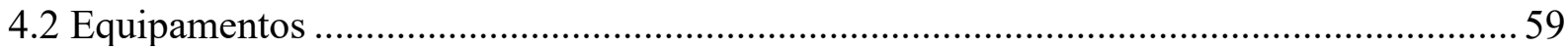

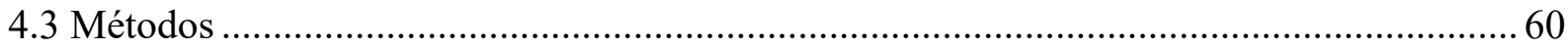

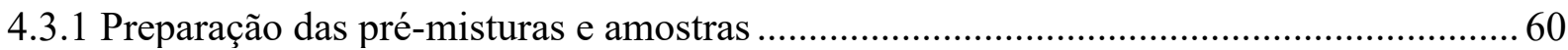



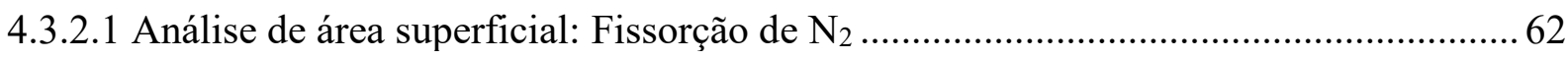

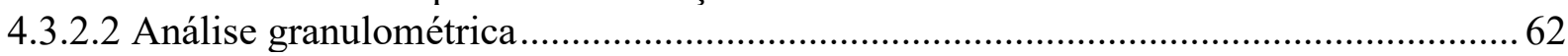

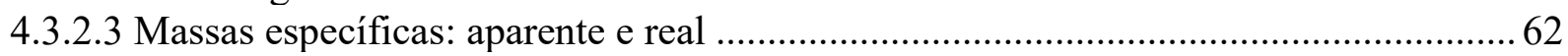

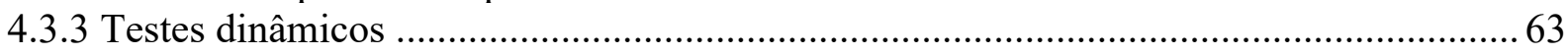

4.3.3.1 Teste de Estabilidade e Fluxo Variável ................................................................... 63



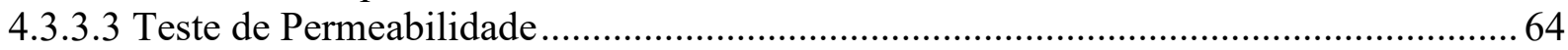

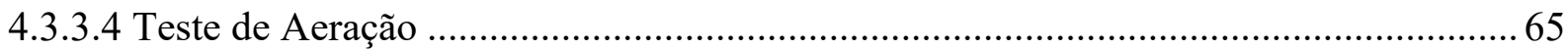

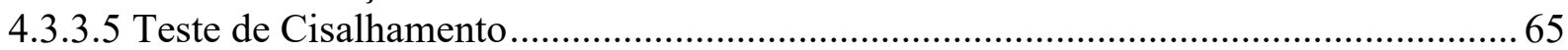

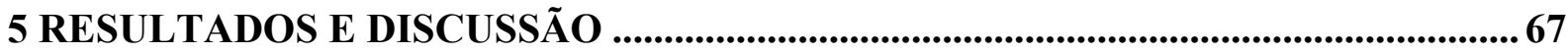


5.1 Resultados para pré-misturas de excipientes farmacêuticos. ........................................67

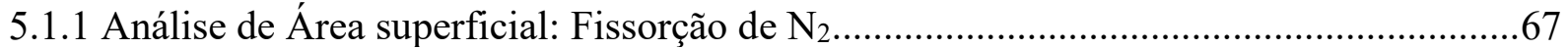

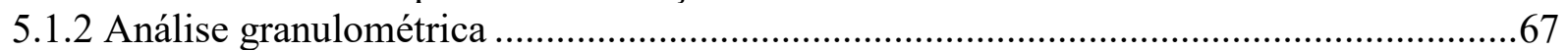

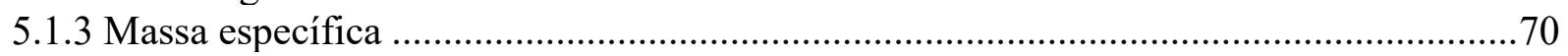

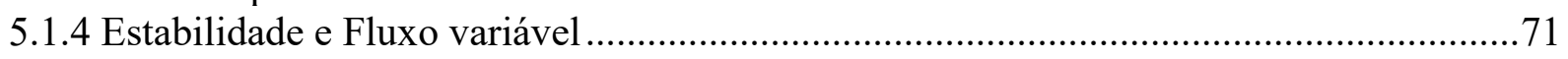

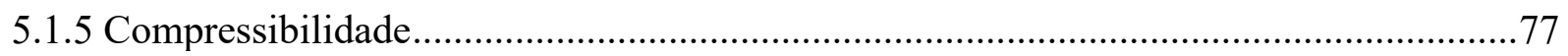

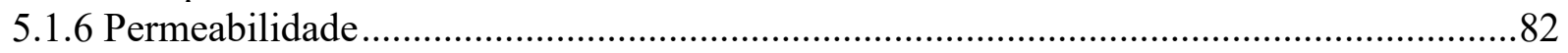

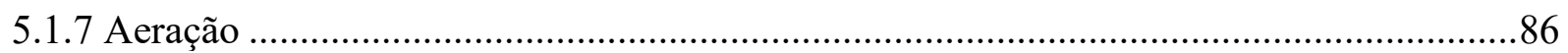

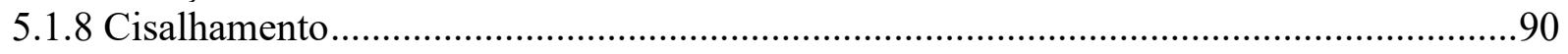

5.2 Resultados para amostras contendo o princípio ativo efavirenz ......................................95

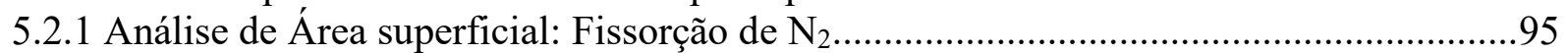

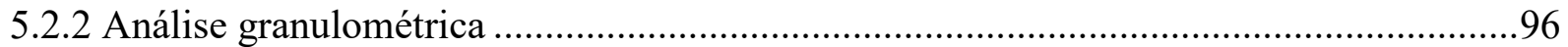



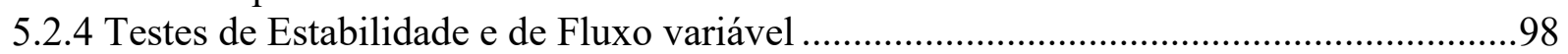

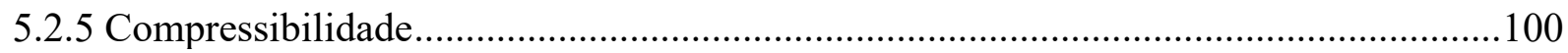

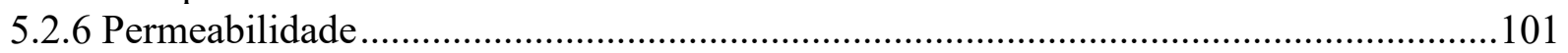

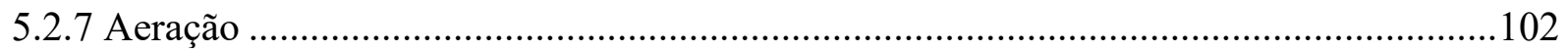

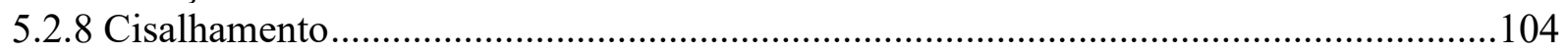



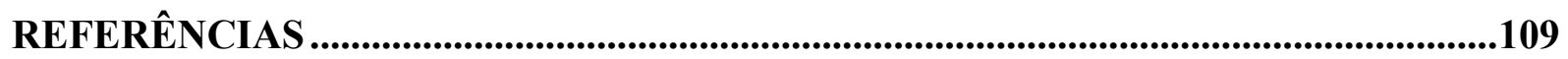

APÊNDICE A - Resultados do BET das amostras de excipientes farmacêuticos ...........117

APÊNDICE B - Resultados da massa específica aparente condicionada das pré-misturas de excipientes farmacêuticos ..........................................................................................119

APÊNDICE C - Resultados do teste de Estabilidade e Fluxo Variável realizado com as pré-misturas de excipientes farmacêuticos.

APÊNDICE D - Resultado do teste de Compressibilidade realizado com as pré-misturas de excipientes farmacêuticos

APÊNDICE E - Resultados do teste de Permeabilidade realizado com as pré-misturas de excipientes farmacêuticos. 135

APÊNDICE F - Resultados do teste de Aeração realizado com as pré-misturas de excipientes farmacêuticos

APÊNDICE G - Resultado do teste de Cisalhamento realizado com as pré-misturas de excipientes farmacêuticos, à 3,6 e $9 \mathrm{kPa}$ respectivamente

APÊNDICE H - Resultado da Área Superficial, do BFE e da Massa Específica das amostras que contêm o princípio ativo Efavirenz. 


\section{INTRODUÇÃO}

Por definição, materiais particulados podem ser pós (conjunto de partículas de origens, estruturas e composições variadas), grânulos (partículas pequenas), pastas (porção de matéria sólida aglutinada) ou lama (mistura viscosa) (SEVILLE; TUZUN; CLIFT, 1997). São materiais frequentes, seja como matérias-primas, catalisadores ou produtos em processos industriais (ROCCO, 1993).

No segmento farmacêutico, sólidos na forma de pó são partículas individuais de tamanhos e formas variadas com interstícios preenchidos por ar distribuídos aleatoriamente. Os granulados por sua vez, originam da transformação (granulação) dos sólidos na forma de pó e representam um produto intermediário utilizado na elaboração das formas farmacêuticas sólidas uma vez que apresentam propriedades tecnológicas e farmacotécnicas mais adequadas para o processamento de comprimidos ou cápsulas e para administração ao doente (COUTO et al., 2000; DIAS, 2007).

O estudo do comportamento e escoamento de materiais particulados, apesar da relevância, é limitado pela ausência de uma demarcação ou conformidade para descrever tais aspectos, pois dado o número de variáveis e fenômenos complexos envolvidos, as propriedades básicas de partículas ou as condições impostas pelos equipamentos que os processam não são suficientes para prever o comportamento do fluxo de pós em grande quantidade (CONDOTTA; MACHADO, 2014).

A abordagem tradicional desse estudo não pondera a taxa de escoamento, as interações interparticulares e as diferentes características que os sólidos particulados apresentam e que variam com os diferentes estados de movimento, graus de tensão e de cisalhamento aos quais são submetidos nas operações unitárias. É um sistema complexo que exibe transições entre os estados quase estático e dinâmico, e que de acordo com a tensão aplicada, pode comportar-se como um sólido ou como um fluido (LUMAY et al., 2012).

Como exemplo dessas variações tem-se o processo de empacotamento desses materiais que é decorrente das propriedades da matéria sólida, do tempo de armazenamento e das causas da compactação. Em contrapartida, sua fluidez, capacidade de escoamento, inicia-se quando o peso das partículas supera a força de atrito e intervém na qualidade da produção em termos de homogeneização e uniformidade de conteúdo.

Em função da diversidade em aplicações industriais e de processos, novas necessidades surgem assim como a importância do conhecimento relacionado à Ciência e a Tecnologia dos Pós. Esse estudo fenomenológico aborda as interações partícula/partícula, partícula/fluido, 
interação entre essas fases e a aplicação delas em processos, o que confere a compreensão básica da maneira como os pós se comportam e pode minimizar perdas de produção, custos elevados, má qualidade, risco para a saúde, incêndio e explosão do pó, resultando em melhorias no controle de qualidade e emissões ambientais, e menos tempo de inatividade em operações unitárias (RHODES, 2008; SMITH, 2016).

$\mathrm{Na}$ indústria farmacêutica, a falta desse conhecimento e a não documentação das principais causas e soluções dos problemas, o que poderia estabelecer uma ferramenta de prevenção, resulta em um vasto conhecimento farmacêutico tácito que é adquirido com a experiência prática e é transferido de profissional para profissional, afetando negativamente o desenvolvimento e a produção de um medicamento.

A ausência de registro e acervo das dificuldades farmacêuticas mais frequentes destacam-se às formas sólidas, principalmente ao longo da etapa de scale up e após a compressão da mistura de pós na fabricação de comprimidos. Diversos fatores estão envolvidos na apresentação desses efeitos indesejáveis como o tipo de deformação (plástica ou elástica) e a variação das propriedades de fluxo de cada componente em função das demais partículas, das condições de processo e ao volume de produção (PAULA; RIBEIRO, 2001).

Dentre os princípios ativos utilizados no tratamento da Síndrome da Imunodeficiência Adquirida (AIDS), Costa et al. (2013) alertam para os problemas físico-químicos do Efavirenz tais como baixas solubilidade aquosa e taxa de dissolução intrínseca que requerem altas doses do princípio ativo para que o medicamento atinja o efeito terapêutico desejável. Esse excedente gera uma concentração inadequada do fármaco no local de ação e está associado a alguns efeitos colaterais sentidos pelos pacientes. Outra prática comum é o fracionamento da dose gerando formulações de sabor desagradável e dificultando a adesão, consequentemente, a eficácia do tratamento. As soluções orais de Efavirenz e pós para suspensão, por sua vez, apresentam desvantagens como a utilização de solventes orgânicos e a baixa estabilidade da suspensão.

Por esses motivos, o objetivo deste trabalho é avaliar as propriedades físicas essenciais de pré-misturas de insumos farmacêuticos, definidas como pré-misturas no setor industrial, e as suas influências nas etapas da produção de comprimidos, constituindo assim, um material base de caracterização quantitativa de insumos comumente presentes nas formulações farmacêuticas cujos resultados possam auxiliar o profissional desse segmento na minimização de alguns problemas no processo de fabricação de fármacos e na otimização de certas formulações atingindo as características desejáveis. 


\section{OBJETIVOS}

O objetivo geral e os objetivos específicos são apresentados a seguir.

\subsection{OBJETIVO GERAL}

Caracterizar por técnicas quantitativas o comportamento físico-químico $\mathrm{e}$ as propriedades de fluxo de pré-misturas constituídas por alguns excipientes farmacêuticos mais utilizados na preparação de medicamentos a fim de analisar como estas características influenciam o processo produtivo.

\subsection{OBJETIVOS ESPECÍFICOS}

Como objetivos específicos do trabalho, são propostos:

a) caracterizar a variação das propriedades de fluxo de pré-misturas de excipientes farmacêuticos, sem a presença de princípio ativo, sob diferentes teores e tipos de agente lubrificante a fim de verificar as possíveis causas que tornam os agentes lubrificantes insignificantes e/ou prejudiciais à fluidez dessas pré-misturas quando adicionados em grandes quantidades;

b) avaliar as propriedades de fluxo de 5 diferentes formulações contendo princípio ativo, no intuito de justificar a escolha da mistura de melhor biodisponibilidade que será realizada por técnicas farmacêuticas pela Fiocruz/ Farmanguinhos;

c) relacionar as propriedades físicas essenciais de dois tipos de pré-misturas com as etapas da produção de comprimidos tais como a movimentação por pás, fluidização e compressão. 


\section{REVISÃO BIBLIOGRÁFICA}

O escoamento de sólidos particulados é influenciado por propriedades relacionadas à natureza do pó e às características do meio. Em se tratando de formas farmacêuticas sólidas, os excipientes e as condições de processo podem interferir em diversos parâmetros dessas misturas. A seguir são apresentados os conceitos para o estudo das propriedades de pré-misturas farmacêuticas e suas possíveis influências no processo produtivo.

\subsection{SISTEMAS PARTICULADOS: UMA BREVE APRESENTAÇÃO DE SUAS CARACTERÍSTICAS}

Material particulado é o termo utilizado para referir-se a um sistema constituído de partículas sólidas que se comportam em conjunto e apresentam variadas origens, estruturas e composições (COELHO, 2007). Geralmente, há três tipos de partículas: orgânicas inertes, orgânicas viáveis e inorgânicas inertes.

As orgânicas inertes se originam de substâncias orgânicas não reativas, proveniente de organismos vivos e contêm componentes derivados do carbono, mas que não estão necessariamente vivos. As orgânicas viáveis são capazes de viver e de se desenvolver ou germinar, enquanto que as partículas inorgânicas são substâncias não reativas e procedem de matéria que nunca teve vida, geralmente desenvolvidas por atrito (KOCHEVAR, 2006).

Quanto à forma das partículas, a geometria esférica atende às características de uma dispersão ideal devido a menor probabilidade de ruptura e deformação mecânica. Já o tamanho da partícula é o fator determinante para a distância entre elas em uma dispersão (PAPINI, 2003). A Tabela 1 apresenta a classificação dos materiais de acordo com a dimensão das partículas.

Tabela 1 - Classificação dos sólidos quanto ao seu tamanho

\begin{tabular}{c|c|c|c}
\hline \multicolumn{2}{c|}{ Wood Manson } & \multicolumn{2}{c}{ Farmacopeia Brasileira } \\
\hline Classificação & Faixa de Tamanho & Classificação & Faixa de Tamanho \\
\hline Sólido grosseiro & $5-100 \mathrm{~mm}$ & Pó grosso & $1,70 \mathrm{~mm}-355 \mu \mathrm{m}$ \\
\hline Sólido granular & $0,3-5 \mathrm{~mm}$ & Pó moderadamente grosso & $710 \mu \mathrm{m}-250 \mu \mathrm{m}$ \\
\hline Pó grosseiro & $100-300 \mu \mathrm{m}$ & Pó semifino & $355-180 \mu \mathrm{m}$ \\
\hline Pó fino & $10-100 \mu \mathrm{m}$ & Pó fino & $180 \mu \mathrm{m}$ \\
\hline Pó superfino & $1-10 \mu \mathrm{m}$ & Pó finíssimo & $125 \mu \mathrm{m}$ \\
\hline Pó ultrafino & $1 \mu \mathrm{m}$ & -- & -- \\
\hline
\end{tabular}

Fonte: Autor, adaptado de Woodcock e Mason (1987). 
Observa-se que um material é classificado segundo determinada faixa de tamanho estabelecida pela Farmacopeia Brasileira se suas partículas passam em sua totalidade pelo tamis de maior abertura nominal de malha e que passam no máximo em $40 \%$ em peso pelo tamis com menor abertura nominal de malha. Já as classificações de pó fino e pó finíssimo referem-se à materiais cujas partículas passam em sua totalidade pelo tamis com abertura nominal de malha de $180 \mu \mathrm{m}$ e $125 \mu \mathrm{m}$, respectivamente.

Em se tratando de material pulverulento, "Fluir" significa deformar-se plasticamente devido às cargas atuantes em um corpo e a magnitude da carga necessária para o fluxo é uma medida da capacidade de escoamento. Assim, fluidez é um conjunto de características físicoquímicas que confere movimento às moléculas partindo de um estado estacionário. $\mathrm{O}$ material apresenta bom comportamento de fluxo se escoar facilmente, não consolidar e fluir para fora de um silo ou tremonha devido à gravidade (SCHULZE, 2011).

Adesão e coesão são termos utilizados para classificar as interações entre as partículas sólidas e podem ser compreendidas como a atração entre dois corpos sólidos produzidas pela existência de forças atrativas intermoleculares de ação à curta distância (FELICETTI, 2008). A adesão refere-se as interações entre as partículas de materiais diferentes, sendo o resultado de forças que existem entre partículas microscópicas e uma superfície sólida em contato. A coesão por sua vez, se refere às interações entre partículas de mesma estrutura química e tamanhos semelhantes (PODCZECK, NEWTON, JAMES, 1995).

O estudo dessas interações é de suma importância quando as forças gravitacionais sobre as partículas são insignificantes frente às forças atrativas entre as partículas. Isso ocorre quando as dimensões das partículas são muito pequenas (diâmetros na ordem de micrômetros), pois as forças gravitacionais são proporcionais ao cubo do tamanho da partícula e diminuem mais rapidamente com o decréscimo no tamanho das partículas em comparação com as forças internas (ZENG, MARTIN, MARRIOTT, 2003). Nesse caso, as forças atrativas entre as partículas são fortes o suficiente para restringir o movimento molecular e forçar as partículas a ocuparem posições específicas em um arranjo tridimensional (BROWN, LEMAY, BURSTEN, 2008).

Considerando as interações das partículas, as forças que atuam sobre elas podem ser classificadas como forças internas e forças externas. As forças internas são forças microscópicas que tendem a restringir a liberdade de movimento independente das partículas e se manifestam macroscopicamente por um efeito de coesão que o pó exibe (COELHO, 2007). As forças internas ou intermoleculares são: íon-dipolo, dipolo-dipolo, Van Der Waals, capilares, ligações de Hidrogênio e pontes sólidas. 
As forças externas são forças que não são orientadas ao acaso e tendem a causar movimento às zonas do pó. São exemplos a gravidade, o impacto da pá de um agitador ou qualquer força externa ao sistema que cause o aumento da pressão em um material pulverulento e force as moléculas a se aproximarem, o que intensifica as forças intermoleculares e pode resultar na deformação plástica das partículas (COELHO, 2007).

As principais forças atuantes sobre as partículas em uma massa de pó não consolidada, são ilustradas na Figura 1, sendo coh as forças coesivas que existem entre as partícula e $m g$ a força peso de cada partícula.

Figura 1 - Principais forças atuando sobre as partículas de material não consolidado.

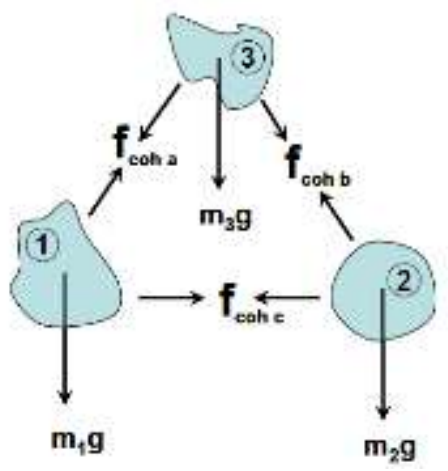

FONTE: Freeman Technology, 2008.

Alguns produtos sólidos continuam a ganhar força se forem armazenados em repouso sobre compressão em um intervalo de tempo mais longo. Esse efeito é chamado de tempo de consolidação ou aglomeração (SCHULZE, 2011). O material pode ainda ser classificado como coesivo ou solto de acordo com o tipo de fluxo. Se o escoamento dá-se em "avalanches" e o pó parece despedaçar e não escoar, o material é dito coesivo, enquanto que no caso dos materiais soltos o escoamento é suave e progressivo. Essa diferença de comportamento está relacionada com o tamanho e rugosidade das partículas, com a massa específica e outras características próprias da natureza do material.

Outro aspecto importante é a massa específica do material que constitui as partículas, pois afeta igualmente a massa e por isso o peso das partículas (COELHO, 2007). Duas massas específicas são utilizadas para caracterizar um material sólido: a massa específica real que considera apenas o volume das partículas sólidas e a massa específica aparente (bulk) que considera todo o volume de material, independente da presença ou ausência de poros.

As superfícies das partículas possuem asperezas na forma de colinas e vales e quando elas se juntam, pode ocorrer o bloqueio das partículas e aumentar a interações entre elas, 
conforme ilustrado na Figura 2. Além disso, o contato entre as partículas irá ocorrer em poucos pontos podendo constituir uma pequena fração do total da área aparente das partículas.

A carga nesses pontos é diretamente proporcional à força aplicada, e as forças serão concentradas sobre uma pequena área da superfície fazendo com que a pressão nesses pontos seja extremamente alta. A pressão local imposta pode fazer com que o material comece a fluir, resultando no aumento da área de contato e permitindo uma maior distribuição da carga até que a pressão imposta não seja suficiente para fazer com que o sólido ceda.

Assim, as partículas com superfícies rugosas apresentam maior tendência à interligarem-se mecanicamente do que as partículas com superfícies mais lisas. No caso de aderir partículas menores às partículas ásperas maiores, as partículas menores podem ser aprisionadas nas asperezas das partículas grandes e essa interação será mais significativa do que às interações intermoleculares e eletrostáticas (ZENG, MARTIN, MARRIOTT, 2003).

Figura 2- Representação do travamento mecânico entre duas partículas.

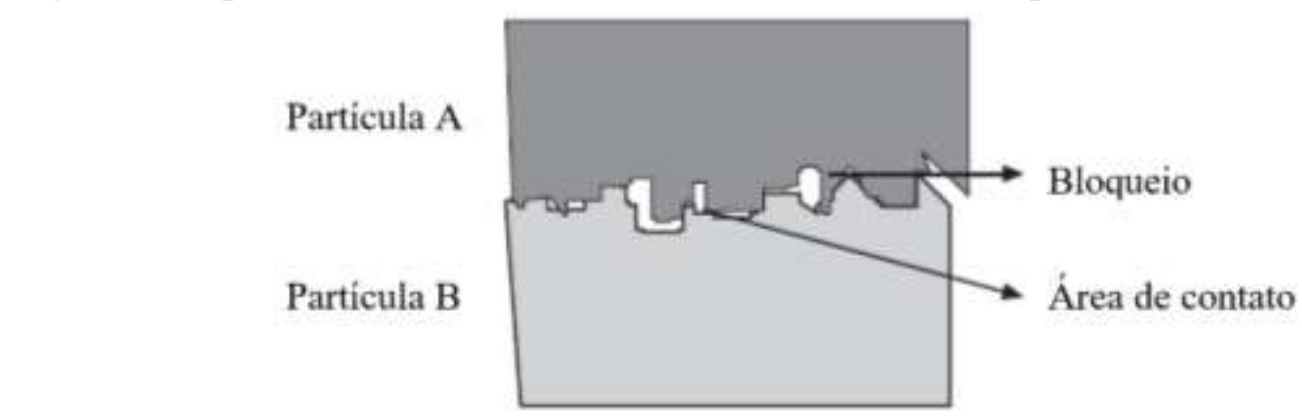

Fonte: Autor adaptado de ZENG, MARTIN, MARRIOTT, 2003.

As propriedades físico-químicas citadas anteriormente além da distribuição de tamanho de partícula, fluidez, compressibilidade, dentre outras, afetam o processo de mistura de materiais granulares, pois quando as partículas contituintes possuem propriedades físico-químicas diferentes a mistura possui comportamento de mistura não ideal uma vez que ocorre a distribuição dos diversos componentes segundo suas propriedades. Esse processo é conhecido como segregação e as diferenças de tamanho de partícula dos componentes é um dos fatores mais influentes (LABASTIE, 1995).

Labastie (1995) apresenta trabalhos de outros autores sobre o fenômeno de segregação medido em sua obra: Considerações sobre pré-misturas de pós farmacêuticos. Nesse artigo, o autor demonstra que a velocidade de segregação em segrenômetros de cisalhamento segue uma cinética linear de acordo com a diferença de tamanho dos componentes, especificamente a partir de diferenças de tamanho não maiores que 3\%, sendo que a diminuição do teor em finos tende a diminuir a velocidade de segregação. No caso de partículas de densidades muito diferentes, a 
segregação aumenta se as partículas mais finas são também as mais densas. Em pré-misturas nas quais ocorrem fenômenos de aderência entre as partículas, as diferenças de tamanho granulométrico não favorecem a segregação uma vez que a aderência a neutraliza em parte. $\mathrm{O}$ autor exemplifica a presença de estearato de magnésio em pré-misturas farmacêuticas que diminui a aderência entre as partículas, consequentemente, favorece a segregação.

\subsection{LEITOS DE MATERIAIS PARTICULADOS}

A seguir são descritos alguns fenômenos interparticulares presentes em diferentes leitos de partículas. Para isso, supõe-se que os leitos são pré-misturas perfeitas de partículas secas.

\subsubsection{Leitos monodispersos constituídos de partículas de pequena granulometria}

As partículas cujas granulometrias são inferiores a $100 \mu \mathrm{m}$ constituem um leito onde pode haver a formação de aglomerados, os quais possuem um espaço interno preenchido por ar, ou seja, as partículas interagem entre si de tal modo em que a resultante das forças atuantes nessas partículas não é vencida pela força peso (P). Essas forças atuantes, por sua vez, são criadas pelo contato entre as partículas que é induzido pelas forças interparticulares (I). A Figura 3 ilustra esse comportamento.

Figura 3 - Aglomerados internamente vazios.
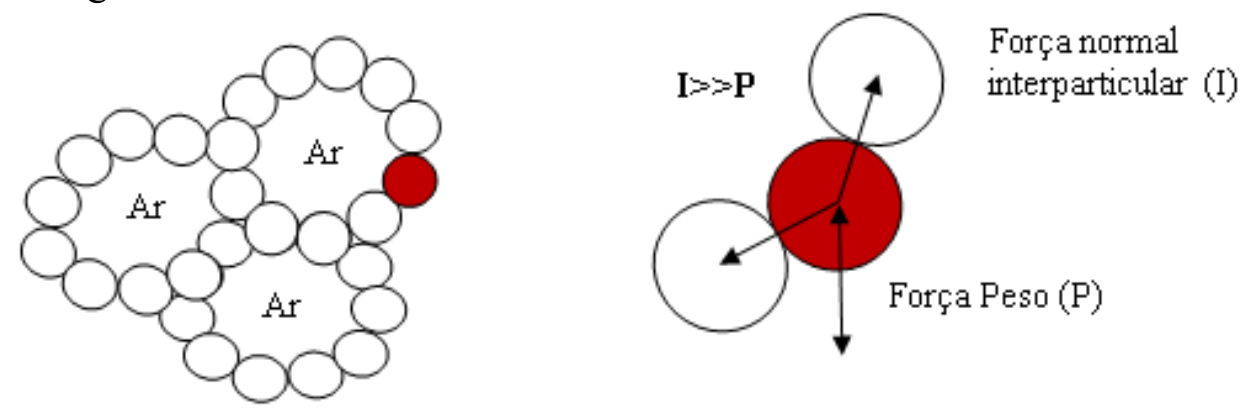

Fonte: Autor, 2018.

Nesse caso, as partículas são leves e a ação da gravidade atuante em uma única partícula não é capaz de vencer as forças interpartículas, desse modo, uma partícula ao ser inserida a um leito de partículas de mesma dimensão, ela aleatoriamente se une a outra partícula antes de completar seu percurso delineado pela ação da gravidade, conforme o ilustrado na Figura 4. 
Figura 4 - Adição de uma nova partícula em um meio que já possui outras partículas.

Trajetória delineada

pela ação da força

interparticular

Trajetória delineada pela

ação da força da gravidade

Fonte: Autor, 2018.

Esse fenômeno também ilustrado na Figura 5, ocorre não apenas durante a adição de novas partículas, mas também após o leito sofrer alguma alteração em seu estado estacionário. Ele é intensificado com o decréscimo do tamanho das partículas, com isso o volume vazio dos interstícios é inverso ao tamanho das partículas.

Figura 5 - Formação do leito de partículas de pequena granulometria.

Fonte: Autor, 2018.

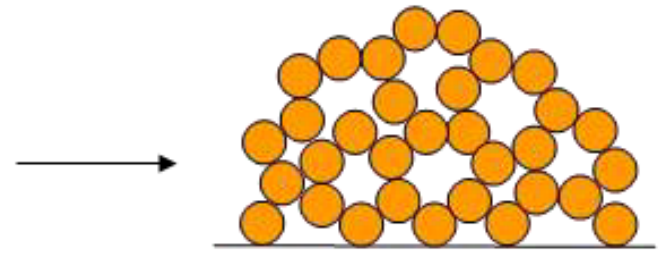

Observa-se que a adição de novas partículas em um leito dificilmente será realizada de maneira individual, mas sim em quantidades de partículas que serão adicionadas na forma de aglomerados caso o processo de adição dessas partículas também não seja capaz de vencer as forças interparticulares.

Esses aglomerados podem vencer as interações interpartículas que se formarão com sua adição ou realocar-se de modo a construir novas interações interpartículas. Vale ressaltar que qualquer agente externo mesmo que mínimo, pode alterar a configuração do leito, caso esse agente seja capaz de vencer alguma interação interpartícula. A Figura 6 ilustra essa característica.

Figura 6 - Leito de partículas após a adição de novas partículas

Fonte: Autor, 2018.

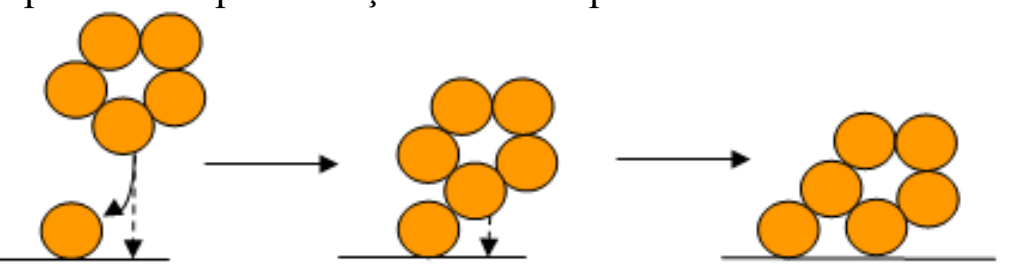


Em se tratando de sólidos de pequena dimensão, é necessário o somatório da força exercida por esse agente em várias partículas para que a força entre as partículas seja vencida. Desse modo, a fluidização do leito não é contínua e conforme as forças interparticulares são vencidas, novas forças interparticulares são formadas e a movimentação desse leito tem um aspecto de quebra e ou avalanche (RHODES, 2008).

\subsubsection{Leitos monodispersos constituídos de partículas grandes}

A posição de uma partícula, cuja granulometria é superior a $100 \mu \mathrm{m}$, em um leito de partículas de mesma ou semelhante dimensão também é aleatória, porém mais organizada que a das pequenas partículas, de modo que a resultante das forças atuantes nessa partícula é vencida pela força normal criada pelo contato induzido pela força gravitacional.

Para cada material, há uma granulometria limite a partir da qual as partículas possuem o peso necessário para desfazer as interações interparticulares. Ou seja, essas partículas densas possuem peso suficiente para que a ação da gravidade seja mais significativa do que as interações interparticulares no delineamento do trajeto do seu movimento. Entretanto, não é suficiente para superar o atrito e os intertravamentos partícula - partícula.

Esse fenômeno é estável para partículas de tamanho superior à dimensão limite e ocorre não apenas durante a adição de novas partículas, mas também após o leito sofrer alguma alteração em seu estado estacionário. A Figura 7 ilustra o leito dessas partículas.

Figura 7 - Leito de partículas quando a ação da gravidade atuante na partícula é capaz de vencer as forças interparticulares

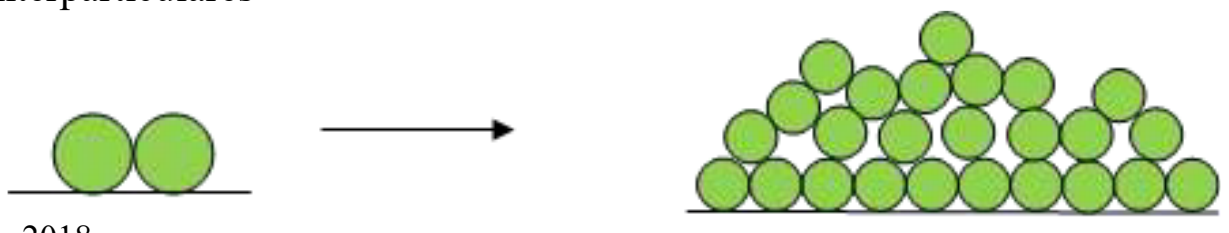

Fonte: Autor, 2018.

A porosidade do leito não é devido à formação de aglomerados, mas sim pelo travamento mecânico entre as partículas que, apesar de serem representadas pela forma esférica, possuem deformações em sua superfície (deformações causadas pelo desgaste, pela porosidade da própria partícula, afastamento da forma da partícula de uma esfera, dentre outros).

Como as forças interparticulares são insignificantes quando comparadas à força peso e são vencidas pela própria partícula, apenas a força peso deve ser vencida para que ocorra a fluidização do material. Essa movimentação do leito é contínua e semelhante à de um líquido, 
pois após atingir a inércia, o travamento mecânico passa a não ser mais pronunciado além de não haver a formação de novas forças interparticulares (RHODES, 2008).

\subsubsection{Leitos dispersos constituídos de partículas de pequena granulometria e partículas grandes}

A posição de uma partícula de pequena dimensão ocorre de modo a preencher os espaços vazios entre as partículas maiores num leito ideal e compacto. Esse preenchimento também é aleatório e pode ser subdividido em três fases. Dependendo da fase, os efeitos das interações interparticulares podem ou não ser pronunciáveis e com isso, a resultante das forças atuantes em uma partícula é anulada ou não pela força peso.

A justificativa para que o preenchimento ocorra em três fases é que, para cada mistura de materiais de diferentes granulometrias, há uma quantidade limite de partículas menores a situarem os espaços vazios entre as partículas maiores, Fase 1, e de acordo com a fração mássica dessas partículas, os espaços vazios podem saturar.

Caso isso ocorra, as partículas menores passarão a preencher a superfície das partículas maiores, Fase 2. O afastamento das partículas grandes entre si diminui o atrito e consequentemente, o efeito do travamento mecânico. Logo, a movimentação do leito é facilitada e as partículas menores são denominadas facilitadores de fluxo. Uma observação importante é que dependendo da magnitude das interações a Fase 1 pode não ocorrer e as partículas podem alojarem-se na superfície das partículas grandes mesmo em quantidades inferiores à quantidade limite de saturação dos poros entre as partículas grandes.

Do mesmo modo que há uma quantidade limite de partículas a preencherem os poros entre as partículas maiores, há uma quantidade limite de pequenas partículas a preencherem a superfície das partículas maiores, Fase 3. Neste caso de saturação, as partículas menores têm contato umas com as outras formando aglomerados com espaços internos vazios. A Figura 8 ilustra as fases do preenchimento dos poros de partículas grandes com partículas pequenas.

Figura 8 - Fases do preenchimento dos poros de partículas grandes com partículas pequenas

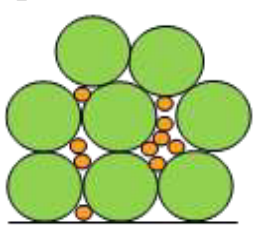

Fase 1

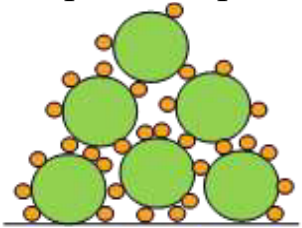

Fase 2

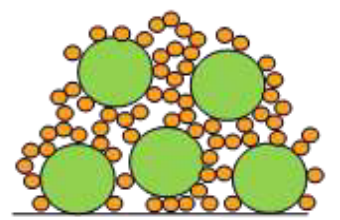

Fase 3

Fonte: Autor, 2018. 
Os leitos representados na Figura 8 são constituídos de partículas pequenas e grandes cuja divisão do tamanho da partícula menor pelo tamanho da partícula maior é muito menor do que 1 (partícula grande é muito maior do que a partícula pequena) e a Fase 1 representada constitui o empacotamento denso em relação às Fases 2 e 3.

Nas fases 1, 2 e 3, o contato entre as partículas grandes entre si é menor e há a presença de mais de uma partícula pequena nos interstícios das maiores. A relação entre o tamanho das partículas pequenas e o tamanho das partículas grandes define o número de partículas grandes em contato entre si para alojar uma partícula pequena em seus interstícios.

A Figura 9 representa o empacotamento denso, no qual a relação entre o tamanho da partícula menor e o tamanho da partícula maior é ainda menor do que 1, porém nesse tipo de empacotamento as partículas menores são alojadas nos interstícios formados pelo contato entre uma quantidade maior de partículas grandes.

Figura 9 - Tipos de empacotamento com apenas uma partícula no interstício

Fonte: Autor, 2018.


Em se tratando de leitos dispersos a relação entre o tamanho das partículas de um leito disperso pode aproximar-se de 1 de duas maneiras: pré-misturas entre partículas de pequena dimensão (partícula grande não é muito maior do que a partícula pequena) e pré-misturas entre partículas de grande dimensão (partícula pequena não é muito menor do que a partícula grande).

Figura 10 - Relação entre o tamanho das partículas próximo de um

Fonte: Autor, 2018.

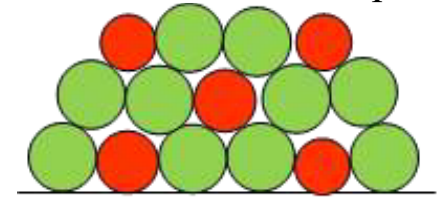

Empacotamento denso

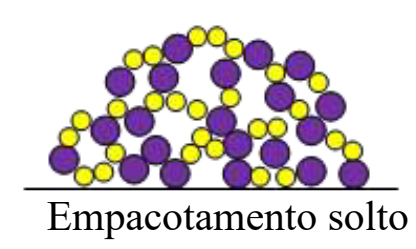

Empacotamento solto

As partículas grandes se acomodam de modo a constituírem um empacotamento denso ou solto, sendo que quanto mais próximo à relação for de um, mais denso é o empacotamento. Enquanto que as partículas menores se alocam de modo a formarem aglomerados internamente 
vazios de modo que quanto menor o tamanho das partículas e mais próximo a razão entre o tamanho delas, maior será o volume vazio dos interstícios formados.

A grande variedade de posicionamentos das partículas num leito disperso requer detalhamento das propriedades físicas essenciais de modo a compreender o empacotamento dessas partículas e interpretar adequadamente os resultados dos testes dinâmicos (RHODES, 2008).

\subsection{SÓLIDOS NO SETOR FARMACÊUTICO}

Esse item apresenta uma breve abordagem sobre as características e classificação dos sólidos no setor farmacêutico.

\subsubsection{Medicamentos}

Medicamentos são preparações químicas que geralmente contêm um ou mais fármacos administrados com a intenção de prevenir, curar doenças ou aliviar seus sintomas. Podem conter em sua composição outras substâncias como excipientes, conservantes e solventes a fim de garantir o desempenho do fármaco e otimizar a obtenção do efeito terapêutico (RANG et al.,2012, p. 1). Devem obedecer um rigoroso controle técnico para atender às especificações definidas pela Anvisa (Agência Nacional de Vigilância Sanitária), pois um medicamento só pode ser comercializado se contiver o aval da ANVISA, e para isso, deve ter sido fabricado com base nas Boas Práticas Farmacêuticas, controlado e acordo com a Farmacopeia e seguir todos os procedimentos de validação, fabricação e ter o devido controle de qualidade (HIPOLABOR FARMACÊUTICA, 2014; LEITE, 2014 e FARMACOPEIA BRASILEIRA, 2010).

\subsubsection{Fármaco}

Fármaco ou princípio ativo, é uma substância química de estrutura conhecida que produz um efeito biológico quando administrado a um organismo vivo. Para ser classificado como tal, deve apresentar propriedades farmacológicas com finalidade medicamentosa de diagnóstico, alívio, ou tratamento, ou ser empregada para modificar ou explorar sistemas fisiológicos ou estados patológicos em benefício do doente. Sua origem pode ser via sintética, 
ou obtida a partir de plantas ou animais, ou um produto de engenharia genética (RANG et al.,2012, p. 1).

\subsubsection{Efavirenz}

O efavirenz é um princípio ativo farmacêutico utilizado no tratamento da Síndrome da Imunodeficiência Adquirida (AIDS) e faz parte da classe de medicamentos inibidores não nucleosídeos de tratamento reverso. Ele é um inibidor seletivo não competitivo da transcriptase reversa do vírus da imunodeficiência humana tipo 1 (HIV-1). A transcriptase reversa do HIV tipo 2 e as DNA polimerases a, $\beta, \gamma$ e $\delta$ de células humanas, por sua vez, não são inibidas por concentrações do Efavirenz muito acima daquelas atingidas clinicamente.

A transcriptase reversa, DNA-polimerase ou RNA-dependente é uma enzima fornecida pelo HIV que produz moléculas de DNA a partir do RNA (processo de transcrição). O HIV, após atacar e penetrar em uma célula de defesa (linfócito), utiliza essa enzima para transformar o RNA viral em DNA viral que é transportado ao núcleo celular onde a enzima integrase catalisa a incorporação do DNA viral ao material genético da célula infectada.

A partir do DNA viral, ocorre a transcrição do RNA e a tradução das proteínas virais que são produzidas na forma de precursores de poliproteínas (longas unidades compostas de enzimas virais e proteínas estruturais). As poliproteínas e o RNA viral são remanejados para a superfície celular a fim de serem incorporados aos novos vírus que surgem na membrana celular e formarem a camada externa viral. Os novos vírus infectarão outras células até que todo o sistema imunológico seja contagiado (SOUZA, 2003).

Como forma de tratamento, o Efavirenz é administrado para inibir a síntese de DNA mediada pela transcriptase reversa sem interferir na ligação dos nucleosídeos (unidades monoméricas constituintes do DNA e RNA), ou seja, esse medicamento não mata o HIV, mas impede o enfraquecimento do sistema imunológico. Para isso, liga-se de modo não competitivo e reversível a transcriptase reversa, alterando sua função (RODRIGUES, 1999).

Como efeitos colaterais pode causar nos pacientes erupção cutânea, náuseas, fadiga, convulsão, prurido (percepção incômoda na pele), dor de estômago, visão turva e sintomas neurológicos (cefaleia, tonteira, distúrbios da marcha, tremor, perda da habilidade motora fina, insônia, sonolência, padrão anormal dos sonhos, alteração do comportamento, amnésia, diminuição da capacidade de concentração, lentidão no processamento mental).

No caso de superdosagem (ingestão adulta acima de $600 \mathrm{mg}$ por dia) foi relatado o aumento de sintomas neurológicos como contrações musculares involuntárias. O tratamento 
da superdose consiste em medidas gerais de suporte, podendo-se administrar carvão ativado para ajudar a remover o medicamento não absorvido. Contudo não há antídoto específico e uma vez que o fármaco se liga fortemente às proteínas plasmáticas, a diálise é ineficaz na remoção por completo do medicamento no sangue (FARMANGUINHOS, 2018).

\subsubsection{Excipiente}

Excipientes ou adjuvantes são substâncias, diferente do fármaco, incluídas na formulação farmacêutica com a intenção de possibilitar a preparação do medicamento no intuito de proteger, fornecer ou melhorar a estabilidade e a disponibilidade biológica do fármaco e aceitabilidade do paciente; propiciar a identificação do produto; melhorar ou promover qualquer outro atributo relacionado a segurança e a efetividade do produto durante a estocagem e/ou o uso.

Essas substâncias podem representar a maior parte da forma farmacêutica (relação em volume) quando comparados com a concentração do fármaco e podem apresentar estruturas moleculares simples, com diferentes funcionalidades ou, até mesmo, moléculas poliméricas complexas de elevado peso molecular.

Pode-se salientar que um excipiente ideal para a formulação de comprimidos é aquele que seja toxicologicamente inativo; não reaja quimicamente com fármaco; compatível com outros ingredientes da formulação; incolor e insípido; apresente boa fluidez e alta capacidade de sofrer compressão (sólido); possa ser obtido a partir de diversas fontes, com custos adequados; seja fácil de ser armazenado; apresente características reprodutíveis lote-a-lote e tenha desempenho consistente com a forma farmacêutica a qual se destina.

Devido à grande variedade de substâncias que podem ser empregadas como excipiente, essas podem ser divididas em classes quanto a sua função. Isso se deve ao fato de que na fabricação de formas farmacêuticas sólidas, as funcionalidades dos excipientes podem interferir em diversos parâmetros das misturas, como compressibilidade, fluidez, lubrificação, friabilidade, uniformidade, tempo de desintegração, estabilidade do ativo, revestimento, dissolução e biodisponibilidade (DELAMAN, 2013). Alguns dos principais tipos de excipientes são: 


\subsubsection{Diluentes}

Diluentes são produtos adicionados às formulações farmacêuticas com o intuito de ajustar o volume do comprimido final de modo que esse apresente dimensões e densidade bruta adequados, e propiciar compressão e propriedades de fluxo necessárias à produção. Podem ser de diferentes naturezas (solúvel, insolúvel ou mista) desde que sejam quimicamente inativos, não higroscópicos, tenham boas propriedades biofarmacêuticas e gosto aceitável.

Um dos diluentes mais utilizados em comprimidos é a lactose por apresentar as características mencionados anteriormente, ter rápida solubilidade em água (21,6 g a cada $100 \mathrm{~mL}$ ) e sabor adocicado. Como desvantagem tem-se incapacidade que algumas pessoas têm de digerir lactose. É uma substância molecular orgânica de origem animal, possui massa molecular de $342 \mathrm{~g} / \mathrm{mol}$, nas condições normais de atmosfera encontra-se na forma sólida, é um carboidrato classificado como dissacarídeo (originada a partir da interação entre uma molécula de glicose e uma de galactose) e possui grupos funcionais das funções orgânicas de álcool e éter (MERK, 2014).

Para fins farmacêuticos pode ser utilizada na forma de alfa-lactose monohidratada (LM) que por ter um aspecto mais áspero com partículas ponteagudas em volta de seu grão, possui baixa fluidez e é empregada exclusivamente em processos de granulação via úmida ou na forma seca por aspersão ou spray-dried (LSD) que foi desenvolvida para aplicação específica em processos de compressão direta com características melhoradas de compactabilidade, e escoamento, ou seja, possui um formato mais esférico, rígido e liso. A Figura 11 ilustra a microscopia eletrônica dessas substâncias.

Figura 11 - Lactose Monohidratada e Lactose Spray - Dried
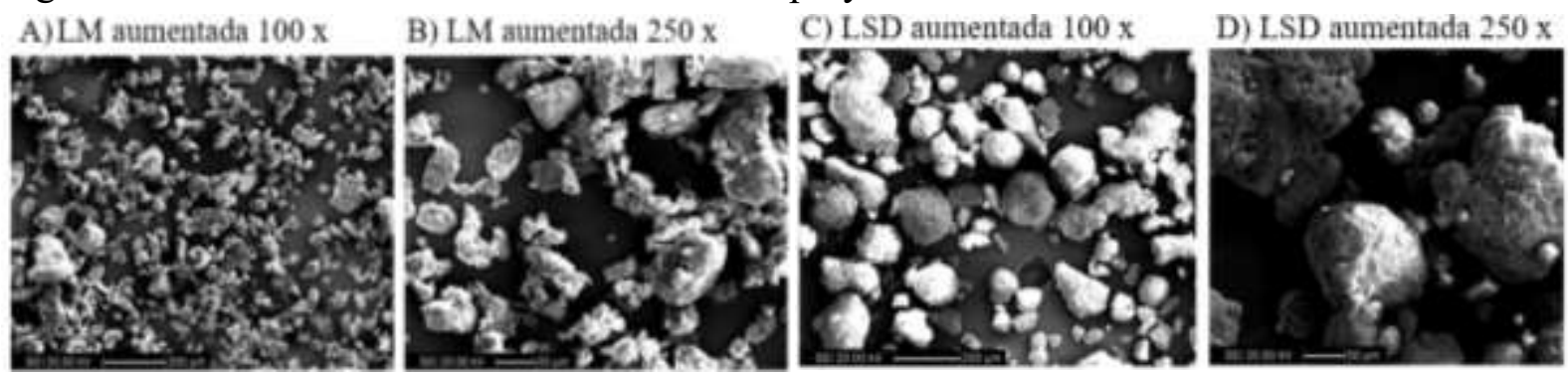

Fonte: Autor, adaptado de Rocha, 2017

O Manitol é um poliálcool isomérico ao sorbitol, originado pela hidrogenação da frutose obtida pela inversão da sacarose (açúcar da cana). Nas condições normais de atmosfera apresenta-se como pó cristalino (coesivo) ou grânulos de cor branca (fluxo livre), inodoro e de 
sabor doce. Possui excelente estabilidade química, térmica e bacteriológica (prolonga o tempo de vida útil dos produtos) e é não higroscópico.

Sua massa molar é de $182,17 \mathrm{~g} / \mathrm{mol}$ e é solúvel em cerca de seis partes de água. É incompatível com infusão de xilitol, forma complexos com alguns metais ( $\mathrm{Fe}, \mathrm{Al}, \mathrm{Cu}$ ), precipita quando em contato com soluções de cloreto de sódio e potássio $(\mathrm{NaCl}$ e $\mathrm{KCl})$ de concentração superior a $20 \%$ e reduz a biodisponibilidade oral da cimetidina (FERREIRA, 2006). É utilizado como agente diluente, edulcorante, veículo, agentes de tonicidade e agente osmótico (PHARMANOSTRA, 2017).

A celulose oriunda da parede celular vegetal é um polímero natural de D-glicose conectada por ligações 1-4 $\beta$ (beta) glicosídicas. A união de várias moléculas de celulose por ligação de hidrogênio forma uma estrutura denominada microfribila. As regiões dessa estrutura que são marcadas por ligações internas frágeis são amorfas, por outro lado, as regiões com grau de ligação interna tridimensional elevado possui forma cristalina, é insolúvel em água e quando isolada (após as etapas de hidrólise ácida, neutralização, purificação, secagem, moagem e peneiramento) produz a celulose microcristalina (CMC ou MCC em inglês) (TOVANI BENZAQUEN INGREDIENTES, 2017).

A MCC, celulose parcialmente despolimerizada, é um pó fino nas condições normais de atmosfera, inodoro, insípido (sem gosto), possui cerca de $70 \%$ a $80 \%$ de cristalinidade e elevada porosidade; suas características de compactação e absorção de água interferem diretamente no fluxo e na estabilidade do medicamento. Apresenta características de fluxo e compactação excelentes e superiores à celulose, podendo dispensar o uso de lubrificantes e ser utilizada para compressão direta, pois requer baixas forças de compressão para gerar uma compactação adequada, resistente e com baixa friabilidade.

Após o processo de compactação, as partículas podem sofrer deformação plástica aglomerando-se devido às ligações de hidrogênio, com isso, a compactação é resistente e menor do que a do amido, sofrendo desagregação. Além de diluente, pode ser empregada como desagregante, agente de esferonização (produção de pellets), lubrificante, absorvente e substituto à lactose, contudo seu custo é elevado em comparação com outros excipientes e é incompatível com oxidantes fortes. Possui densidade aparente de $0,45 \mathrm{~g} / \mathrm{cm}^{3}$, é estável e higroscópico.

Com o intuito de aperfeiçoar as características da celulose, ela é lavada, desintegrada e seca por de spray-dried, obtendo-se um pó deformável de partículas finas e compridas com aspecto de laminas. Dentre as Microceluloses, existem dois tipos mais comuns: a Microcelulose 101 (MCC 101) que é aplicada principalmente em granulação úmida e esferonização e a 
Microcelulose 102 (MCC 102 que possui excelente adequação em processos de compressão direta. (FERREIRA, 2006).

\subsubsection{Deslizantes}

Melhoram as propriedades de fluxo nas pré-misturas farmacêuticas de partículas sólidas por reduzirem a fricção interparticular. O deslizante dióxido de silício é um mineral obtido pela hidrólise da fase de vapor de um composto de sílica, se apresenta como um pó submicroscópico amorfo, fino, não arenoso, leve, branco, higroscópico, inodoro e insípido, de massa molar de $60,08 \mathrm{~g} / \mathrm{mol}$. É um óxido anfótero (neutraliza uma reação ácida ou básica) devendo-se atentar apenas para a sua incompatibilidade com dietilestilbestrol e tomar os devidos cuidados no manejo de sua forma em pó, pois quando inalado em grandes quantidades pode desencadear bronquite e silicose (FERREIRA, 2006).

Seu pequeno tamanho de partícula e grande área de superfície específica proporcionam características desejáveis de escoamento, uma vez que envolvem as partículas maiores dos excipientes e dos ingredientes ativos, reduzindo, assim, as forças de atração de Van Der Waals entre elas. Esse efeito melhora a uniformidade da dosagem e aumenta o rendimento do processo. Com isso, é usualmente empregado como agente deslizante $(0,1-0,5 \%)$ no processamento de comprimidos, podendo também, ser empregado como adsorvente, dessecante, agente suspensor (2,0 - 10\%), agente de viscosidade (2,0 a 10\% em supositórios contendo excipientes lipofílicos para aumentar a viscosidade e prevenir a sedimentação durante a moldagem.) e agente anticaking.

Ao absorver a umidade presente na superfície de pós higroscópicos, minimiza a formação de aglomerados e aglutinações, prevenindo a formação de pontes e caminhos preferenciais no pó. Em vista disso, é adequado para processos de mistura por cisalhamento curto e/ou baixo. O dióxido de silício também ajuda no aperfeiçoamento das propriedades do produto acabado uma vez que produtos hidrofílicos podem, em alguns casos, aumentar a dureza dos comprimidos sem aumentar a força de compactação. O que auxilia na estabilização sem aumentar o tempo de desintegração dos comprimidos densos prensados por força de compactação mais alta (EVONIK, 2017). 


\subsubsection{Desagregantes}

Os desagregantes são também conhecidos como desintegrantes, são empregados para propiciar as condições de liberação do fármaco, ou seja, facilitar a quebra da molecular do fármaco quando em solução. Tendo em vista que o tempo de desintegração (limite para que ocorra a total desagregação do medicamento) pode variar de acordo com a ação desejada e função das substâncias ativas (analgésicos devem desagregar-se mais rapidamente do que as vitaminas) e com a velocidade de absorção que se pretende (RAMOS; MORAES, 2013).

O desagregante croscarmelose sódica $(\mathrm{CMNa})$ ou carboximetilcelulose sódica com ligação cruzada é um pó branco ou acinzentado de livre dispersão, inodoro, estável, higroscópico, insolúvel em água e possui densidade aparente de 0,529 g/ $\mathrm{cm}^{3}$ (FERREIRA, 2006). A ligação cruzada das fibras torna o material hidrofílico, altamente absorvente de água com poder de dilatação total, mantendo sua integridade fibrosa. Essa grande força de dilatação pode ser atribuída a uma combinação de seu tamanho de partícula e excelente grau de substituição (DFE PHAMA, 2017).

A rápida penetração de água nos comprimidos por meio de partículas hidrofílicas e fibrosas e a subsequente força de desintegração desenvolvida tornam a croscarmelose sódica muito eficaz no processo de desintegração. É uma opção para formulações que requeiram produtos sem amido e pode ser utilizada como superdesintegrante intragranular, extragranular ou ambos (FERREIRA, 2006). Sua eficácia desintegrante pode ser levemente reduzida em formulações que contenham excipientes higroscópicos como o sorbitol e é incompatível com ácidos fortes e sais solúveis de ferro, alumínio, mercúrio e zinco (SACHET, 2013).

\subsubsection{Lubrificantes}

São substâncias capazes de otimizar os processos produtivos ao prevenir a aderência e diminuir o atrito dos pós e granulados nas superfícies metálicas das punções e matrizes, transmitir melhor a força de compressão através do pó por reduzir a fricção entre as partículas, facilitar o escoamento no alimentador e o enchimento de cápsulas (SILVA, 2013; FERREIRA, 2006).

O lubrificante mais utilizado industrialmente é o estearato de magnésio. Constituído de magnésio e ácido esteárico, é obtido dos óleos vegetal e animal, possui massa molar de 591,34 $\mathrm{g} / \mathrm{mol}$ e densidade específica $1,03 \mathrm{~g} / \mathrm{cm}^{3}$. Nas condições normais de atmosfera é um pó fino, branco, coesivo, estável, com odor característico do ácido esteárico e é praticamente insolúvel 
em água (solubididade de $0,003 \mathrm{~g} / 100 \mathrm{~mL}$ de água à $15^{\circ} \mathrm{C}$ ) (COSMO QUÍMICA, 2015; SILVA, 2013).

Por ser um lubrificante hidrofóbico, diminui a penetração de líquidos nas formulações e reduz a velocidade de dissolução. Logo, deve ser empregado na menor concentração possível $(0,25 \%)$ ou em combinação com um agente tensoativo como o lauril sulfato de sódio para favorecer a diluição pelos fluidos gastrintestinais. É incompatível com ácidos fortes, álcalis e sais de ferro, não pode ser empregado em formulações contendo ácido acetilsalicílico, algumas vitaminas e sais alcaloídicos, sua mistura com substâncias fortemente oxidantes deve ser evitada (FERREIRA, 2006).

\subsection{FASES DO DESENVOLVIMENTO DE PRODUTOS FARMACÊUTICOS}

O desenvolvimento de novos produtos ocorre em complexos científico-tecnológicos e consiste em nove fases e quatro estágios tecnológicos. Dentre as fases estão a pré-formulação (fármaco ou substância ativa nova), formulação (seleção dos adjuvantes por meio de testes de bancada), estabilidade acelerada ou stepping up (verificação da compatibilidade entre substância ativa e adjuvantes), scalling up (transferência para a escala piloto ou industrial), controle e validação do processo (confirmação que o processo realiza o esperado), estudo de estabilidade em prateleira, registro e lançamento no mercado (PAULA; RIBEIRO, 2001).

O primeiro estágio consiste na pesquisa e desenvolvimento (P\&D), resulta no patenteamento de um novo fármaco e do processo de sua obtenção e corresponde a um objetivo estratégico econômico, social e/ou político. A centralização da pesquisa ocorre por razões estratégicas, sendo elas a proximidade do centro de decisão; sigilo; necessidade de aproveitamento de economias de escala na P\&D; e infraestrutura técnica e econômica dos países desenvolvidos.

O segundo estágio consiste na produção de formulações. A produção de especialidades farmacêuticas consiste no terceiro estágio e ocorre em países com razoável capacidade de formulação de medicamentos e domínio de atividades produtivas, mesmo quando importam quase que a totalidade das matérias-primas necessárias. $\mathrm{O}$ quarto estágio, marketing e comercialização das especialidades farmacêuticas, não exige capacitação produtiva podendo ocorrer em pequenos países sem produção farmacêutica local.

O domínio dos dois primeiros estágios gera vantagens às as empresas para manter uma posição fortemente competitiva no mercado global, enquanto que a integração dos últimos com os primeiros estágios é fundamental no processo de competição (VIEIRA; OHAYON, 2006). 


\subsection{ETAPAS DA PRODUÇÃO E PROBLEMAS NO PROCESSO DE FABRICAÇÃO DE FÁRMACOS NA FORMA SÓLIDA}

Para a produção de comprimidos é feito previamente uma tamisação dos pós (peneiramento) seguida pela a etapa de mistura. Essas etapas têm por objetivo padronizar a granulometria da mistura pulverulenta e garantir uma uniformidade na sua distribuição, com isso, evitar problemas de variação de teor dos comprimidos. A etapa de granulação pode ser realizada por dois processos conforme o ilustrado na Figura 12 e tem por objetivo melhorar as propriedades de fluxo e características de compressibilidade da mistura de pós.

Na granulação via úmido, prepara-se o aglutinante e procede-se com uma umidificação dos pós. O granulado obtido é levado à estufa e o tempo e a temperatura se secagem variam de acordo com a constituição do produto. Após a secagem, calibra-se o granulado irregular por meio de um granulador, onde é forçado a passar por uma malha menor. Na granulação seca, tem-se a pré-compressão (compactação dos pós para que haja sua agregação e possibilite uma posterior granulação) e a calibração (FERRAZ, 2017). É uma alternativa à granulação úmida, quando o fármaco é solúvel em água ou não suporta umidade e a secagem pelo calor.

Figura 12 - Representação do processo produtivo

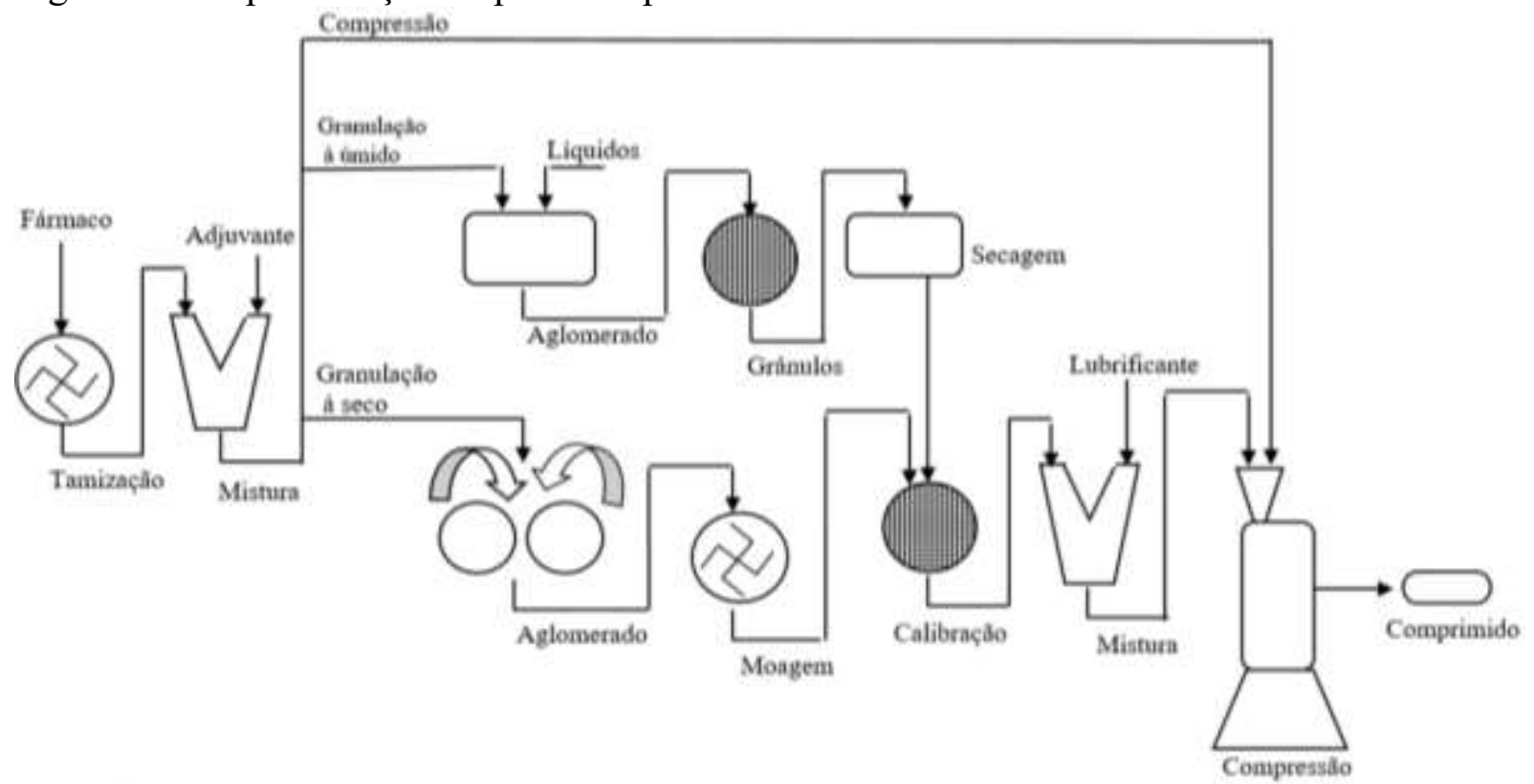

Fonte: Autor, 2018.

Após a granulação adicionam-se lubrificantes que impedem a aderência de pós nos punções da compressora e aglutinantes que aglutinam os grânulos para a formação do comprimido. Prossegue-se com a compressão que pode ser realizada sem que haja a granulação 
a seco e a úmido. Sendo um processo mais moderno, baseia-se na utilização de adjuvantes que permitem a compressão direta de uma mistura de pós (FERRAZ, 2017; LEITE, 2014).

A compressão inicia-se com a alimentação do material na câmara de compressão na qual o peso e dureza do comprimido dependem da força e do volume da câmara de compressão, sendo essa o espaço formado pela matriz e pelo punção inferior (a coesão do material e a pressão exercida influenciam essa etapa). O comprimido é ejetado pelo movimento ascendente da punção inferior e o sucesso dessa etapa é relacionado com a ausência de propriedades abrasivas.

As máquinas de compressão podem ser excêntricas que apresentam uma matriz e um par de punções e são utilizadas em escala piloto, ou máquinas rotativas que apresentam várias matrizes e jogos de punçoes e são utilizadas em larga escala. A configuração errônea dessas máquinas como existência de folgas entre a matriz e os punções, absorção de umidade durante a compressão, emprego de punções e matrizes riscados e lubrificantes insuficientes pode gerar comprimidos com irregularidades (LEITE, 2014).

Os parâmetros das operações unitárias descritas devem ser ajustados para cada tipo de formulação sólida em busca da otimização do processo e qualidade do produto final. Geralmente esse refinamento se dá em pequena escala e não é necessariamente reproduzido na planta industrial uma vez que as formulações otimizadas em escala de bancada apresentam alterações em suas propriedades físicas quando produzidas em escala industrial.

Com isso, o scale up de um processo farmacêutico (partida e operação bem procedida de uma unidade de produção industrial baseada no aumento de escala) é quase sempre problemático podendo resultar em uma série de empecilhos e gerar produtos finais de má qualidade. De modo geral, os principais problemas que ocorrem durante a fabricação de comprimidos, drágenas, comprimidos revestidos, são eles a friabilidade elevada, baixa dureza, contaminação por microrganismos patogênicos, não compressão da mistura (picking), aderência aos punções superiores e inferiores (sticking), aderência às matrizes e rachadura, laminação e quebra horizontal do comprimido (capping), sendo esse o mais indesejável.

Esses inconvenientes são responsáveis pela deformação, variação de peso e da concentração do fármaco nos comprimidos e têm como possíveis causas a umidade dos granulados; absorção de umidade na compressão; punções e matrizes riscados; folgas entre as matrizes e os punções inferiores ou deficiência de lubrificante.

No trabalho: "Problemas de scaling up no desenvolvimento de produtos farmacêuticos', os autores Paula e Ribeiro (2001) relatam que o efeito capping ainda pode ser causado caso comprimidos pequenos sejam preparados por grânulos grandes. Com isso, grânulos menores 
ou iguais a $1 \mathrm{~mm}$ devem ser utilizados em comprimidos de $11 \mathrm{~mm}$ de diâmetro e os grânulos de no máximo 1,5 mm, em comprimidos maiores de $11 \mathrm{~mm}$.

Outro obstáculo a ser vencido e estudado por Paula e Ribeiro (2001) é a quebra excessiva pelo turbilhonamento dos comprimidos durante o drageamento, para isso, utilizam-se núcleos obtidos por compressão com $80 \mathrm{~N}$ de dureza. O lote de matéria-prima e/ou adjuvante também influencia a qualidade do produto final e a utilização de materiais provenientes de um fornecedor habitual que apresente uma boa política de qualidade pode amenizar o impacto dessa vertente.

O scale down, formulação e processamento de uma mistura removendo-se um componente presente na fórmula original, é muito utilizado para verificar o componente responsável pela instabilidade e não conformidade do processo de produção. Outro recurso utilizado para minorar as perdas é a trituração e re-granulação do lote perdido que pode ser adicionado de outros adjuvantes ou ser reprocessado com os novos ajustes dos parâmetros do processo. É uma alternativa s ser realizada com cautela, pois a exposição às condições ambientais e a perda mesmo que mínima do material comprometem a dose do fármaco, o efeito terapêutico e a vida de prateleira do comprimido (PAULA; RIBEIRO, 2001).

Além das barreiras de produção a serem vencidas, a baixa biodisponibilidade do Efavirenz (EFV) tem despertado interesse industrial de modo a melhorar suas características de dissolução por meio do desenvolvimento e caracterização de sistemas. Segundo Castro (2017), o fármaco efavirenz está incluso na Classe II do Sistema de Classificação Biofarmacêutica (SCB) com baixa solubilidade e alta permeabilidade, sendo que a máxima biodisponibilidade atingida pelos medicamentos de Efavirenz disponíveis no Brasil é de 45\%.

Costa et al. (2013) alertam que esses problemas físico-químicos do Efavirenz podem dificultar a formulação uma vez que os fármacos cuja taxa de dissolução intrínseca é inferior a $0,1 \mathrm{mg} \cdot \mathrm{cm}^{-2} \cdot \mathrm{min}^{-1}$ têm a dissolução como um passo limitante para a taxa de absorção. Com isso, os efeitos colaterais sentidos por alguns pacientes podem ser atribuídos às altas doses necessárias para atingir um efeito terapêutico, a uma concentração inadequada de fármaco no local de ação e / ou à baixa biodisponibilidade do efavirenz.

A Tabela 2 relaciona etapas do processo com algumas variáveis a serem consideradas a fim de prevenir os principais problemas que ocorrem durante a fabricação de comprimidos. Observa-se que as etapas de entrada e saída estão diretamente relacionadas com as caraterísticas das partículas enquanto que as demais etapas são influenciadas indiretamente uma vez que as variáveis como tensão de cisalhamento, velocidade da rosca e de compressão e força de 
compressão dependem das propriedades do leito que são delineadas pelas iterações interparticulares.

Tabela 2 - Etapas da produção de comprimidos com suas principais variáveis

\begin{tabular}{|c|c|}
\hline $\begin{array}{l}\text { Etapa do } \\
\text { processo }\end{array}$ & Variáveis \\
\hline Entrada e saída & $\begin{array}{l}\text { Matéria prima; tamanho, forma e superfície da partícula; massa } \\
\text { específica; umidade; composição. }\end{array}$ \\
\hline Mistura & $\begin{array}{l}\text { Tipo de misturador; tensão de cisalhamento; nível de preenchimento; } \\
\text { tempo de resistência }\end{array}$ \\
\hline Granulação úmida & $\begin{array}{l}\text { Umidade; velocidade do rotor; velocidade da rosca; nível de } \\
\text { preenchimento; tempo; temperatura. }\end{array}$ \\
\hline Secagem & $\begin{array}{l}\text { Tipo de equipamento; tempo de resistência; temperatura do ar; aeração } \\
\text { (Fluidização). }\end{array}$ \\
\hline Moagem & Tipo de equipamento; tamanho da lâmina; tempo; velocidade do ar. \\
\hline Mistura & $\begin{array}{l}\text { Tipo e porcentagem mássica de lubrificante; tipo de misturador; tensão } \\
\text { de cisalhamento; nível de preenchimento; tempo de resistência. }\end{array}$ \\
\hline Compressão & $\begin{array}{l}\text { Velocidade de compressão; tipo de alimentador; tempo de } \\
\text { permanência; força de compressão; modo de controle. }\end{array}$ \\
\hline
\end{tabular}

Condotta, 2005.

\subsection{PROPRIEDADES FÍSICAS DAS PARTÍCULAS: CONHECIMENTO RELACIONADO À CIÊNCIA E A TECNOLOGIA DOS PÓS}

A caracterização física dos sólidos pode ser realizada quanto ao nível molecular, de partículas ou à granel e as propriedades relacionadas à estrutura química das partículas podem ser determinadas pela análise de um pequeno conjunto de moléculas individuais, pois representam as propriedades moleculares do material granular. As propriedades de fluidez requerem a análise de um conjunto de partículas e são influenciadas por agentes externos e pelo meio em que o material se encontra. Em vista disso, um material particulado pode ser caracterizado por testes estáticos ou dinâmicos.

\subsubsection{Testes Estáticos}

Medem as propriedades dos materiais particulados no estado de repouso. 


\subsubsection{Análise de Area superficial: Fisissorção de $\mathrm{N}_{2}$}

Este procedimento utiliza dados referentes à isoterma de adsorção e desorção de um gás não reativo (adsorvato) sobre a superfície de um material (adsorvente) e equações provenientes do processo de adsorção cuja ideia central é derivada da teoria de Langmuir, modelo de adsorção em monocamada para se estimar a área superficial das partículas sólidas (COSTENARO et al., 2010 e CALPA, 2011). Atualmente, o modelo desenvolvido por Brunauer, Emmett e Teller (BET) é o mais referenciado na literatura.

A adsorção ocorre pelo desequilíbrio de cargas das moléculas da superfície de um material que na tentativa de encontrar o equilíbrio, permitem que outras moléculas se adsorvam sobre sua superfície. Esse processo de adsorção pode ser físico (fisisorção) ou químico (quimisorção). $\mathrm{O}$ preenchimento dos microporos acontece por fisisorção, e os meso e macroporos por adsorção em monocamada (multicamada seguida de condensação).

No processo utiliza-se nitrogênio como gás adsorvato, na sua temperatura de ebulição (77 K). A uma determinada pressão mínima, os poros menores são preenchidos com o gás, que fica no seu estado líquido e os poros maiores são preenchidos (início do processo de multicamada) com o incremento da pressão (pressão relativa superior a 0,99 ) até seu preenchimento total. Quanto menor o poro, maior o potencial de adsorção.

No caso em que o poro seja suficientemente amplo, as moléculas se adsorvem em uma única camada (monocamada) e na medida que a quantidade adsorvida aumenta, o adsorvato se ordena em camadas sucessivas (multicamada) e a força que origina o processo de multicamada é a mesma que produz a condensação usualmente acompanhada de histerese. A quantidade total dos poros é determinada pela quantidade de gás adsorvido na pressão final ou pressão de saturação. Ao diminuir a pressão, o processo de desorção começa seu curso (CALPA, 2011).

\subsubsection{Análise Granulométrica}

Nessa análise são obtidos os tamanhos característicos de uma amostra de partículas (diâmetro médio superficial, volumétrico, média, mediana, dentre outros) além do tipo de distribuição das partículas, que pode ser monodisperso, bi-disperso, poli-dispersos. Estas duas informações são primordiais para a caracterização de um conjunto de partículas.

Para partículas com tamanhos entre $100 \mathrm{~nm}$ e $1 \mathrm{~mm}$, a técnica mais empregada é a análise granulométrica por difração à laser. O método desse equipamento consiste na dispersão das partículas num fluido em movimento que, ao serem detectadas por uma luz incidente, têm 
seu tamanho determinado. A luz incidente sofre uma interação com as partículas por diferentes fenômenos (difração, refração, reflexão e absorção) formando um invólucro tridimensional de luz. O princípio do método é que o ângulo de difração é inversamente proporcional ao tamanho da partícula.

Detectores estrategicamente posicionados medem a intensidade e o ângulo da luz espalhada e esse sinal é convertido por softwares matemáticos em tamanho e distribuição de tamanho de partícula. Os aparelhos mais comuns são compostos por uma unidade óptica que faz a análise propriamente dita, uma unidade de preparação de amostra que transporta a amostra até a unidade ótica e um microcomputador com software específico para o tratamento do sinal.

Alguns dispositivos realizam a análise tanto em via seca como em via úmida; outros possuem o recurso de ultrassom para a dispersão de aglomerados. O método a seco é uma análise destrutiva e consiste na injeção de ar para dispersar as partículas, já na análise a úmido a amostra pode ser recuperada ao final, porém pode ocorrer a solubilização de alguns materiais e pode não ocorrer a dispersão de materiais higrofóbicos. Consequentemente o método de análise dever ser selecionado de acordo com as características do material analisado (MALVERN, 2015).

\subsubsection{Massa específica}

Massa específica é a relação entre a massa e o volume de um corpo, apresenta uma diversidade de definições que é função do parâmetro volumétrico considerado, do tamanho, distribuição, forma, textura e forças coesivas das partículas, das variáveis externas como nível de tensão de consolidação e vibração, dentre outros fatores que controlam e afetam a relação entre o volume de partículas e o espaço vazio. Consequentemente é necessário a sua medição em um estado conhecido e controlado, o que caracteriza a massa específica de acordo com a técnica utilizada para sua obtenção (FREEMAN TECHNOLOGY, 2008).

\subsection{Massa específica aparente}

Definida como a razão entre a massa e o volume total ocupado pelo leito de um material também é conhecida como massa específica aerada ou bulk density, pois no cálculo todo o volume é considerado, independentemente dos poros (MACHADO, 2014). 


$$
\rho_{\text {aparente }}=\frac{\text { massa da amostra }}{\text { volume total }}
$$

O volume total é calculado por:

$$
\text { volume total }=\text { volume de sólido }+ \text { volume de poros }
$$

\subsection{Massa especifica real}

Massa específica real ou absoluta tem como parâmetro volumétrico o volume das partículas sólidas, desconsiderando todos os poros (ABDULLAH; GELDART, 1999). Com isso, será sempre maior do que a sua massa específica aparente e é calculada por:

$$
\rho_{\text {real }}=\frac{\text { massa da amostra }}{\text { volume real }}
$$

\subsubsection{Testes Dinâmicos a partir do Reômetro de Pó FT-4.}

Esses testes mensuram as propriedades dos materiais granulares por meio de medidas dinâmicas e de cisalhamento (método empírico) e podem ser realizados com o Reômetro de Pó, modelo FT-4 da empresa Freeman Technology. O princípio de operação do FT4 estabelece uma condição de fluxo dinâmico reprodutível que se assemelha à forma como os pós se movem durante o manuseio e o processamento. Para isso, é estabelecida uma trajetória helicoidal a ser percorrida por uma lâmina torcida através de um leito de pó. Esse caminho é determinado pela combinação das velocidades axiais e rotacionais conforme ilustrado na Figura 13.

Figura 13 - Padrão de fluxo.
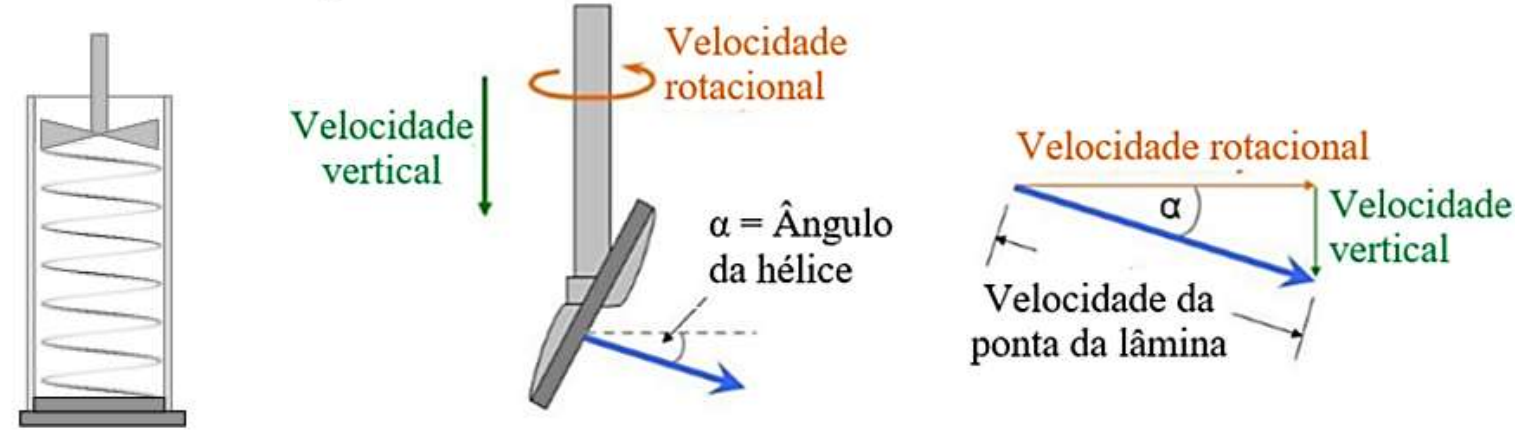

Fonte: Autor adaptado de Freeman Technology, 2008. 
As forças que causam a deformação no leito de partículas são impostas pela lâmina móvel e a energia necessária para movimentá-la é calculada por sensores de força e torque. Os dados são coletados e utilizados como base para a avaliação da capacidade de escoamento. A lâmina é fabricada de forma precisa e não altera o ângulo de torção, contudo sua rotação no sentido anti-horário causa o movimento do material e a sua rotação no sentido horário resulta no processo de condicionamento no qual ocorre a homogeneização da amostra e o alivio das tensões causadas durante os ensaios (FREEMAN TECHNOLOGY, 2008).

\subsubsection{Teste de Estabilidade e Fluxo Variável}

Ao término dos dois testes, são fornecidos parâmetros que caracterizam o material e indicam a confiabilidade da repetitividade dos testes como a massa específica aparente (CDB), energia básica de fluxo (BFE - expressa em mJ) e índice de fluxo (FRI). O teste de estabilidade garante que as propriedades obtidas no teste de fluxo variável sejam devido à variação da velocidade de rotação da lâmina que movimenta o pó, e não dos fenômenos de instabilidade da amostra.

O teste de estabilidade é constituído por uma série de sete ciclos de condicionamento à velocidade constante da lâmina. Ao fim das 7 medidas, o teste do fluxo variável é iniciado com a realização de quatro medidas à diferentes velocidades de rotação da lâmina. No teste de estabilidade, o índice de estabilidade (SI) é calculado por:

$$
S I=\frac{\text { energia total do teste } 7}{\text { energia total do teste } 1}
$$

A classificação para a fluidez de materiais pulverulentos segundo o Índice de Estabilidade é apresentada na Tabela 3.

Tabela 3 - Classificação da fluidez segundo o Índice de Estabilidade.

\begin{tabular}{c|l|l}
\hline SI & \multicolumn{1}{|c}{ Classificação } & \multicolumn{1}{c}{ Possíveis causas } \\
\hline 1 & $\begin{array}{l}\text { Material robusto; não apresenta } \\
\text { sensibilidade ao fluxo variável. }\end{array}$ & Material não coesivo. \\
\hline$>1$ & $\begin{array}{l}\text { Material instável; apresenta } \\
\text { sensibilidade ao fluxo variável. }\end{array}$ & $\begin{array}{l}\text { Desaeração, aglomeração, separação; } \\
\text { umidade, carga eletrostática, dentre } \\
\text { outros. }\end{array}$ \\
\hline$<1$ & $\begin{array}{l}\text { Material instável; apresenta } \\
\text { sensibilidade ao fluxo variável. }\end{array}$ & $\begin{array}{l}\text { Atrito, desaglomeração, aditivo de } \\
\text { fluxo; redução do coeficiente de atrito, } \\
\text { dentre outros. }\end{array}$ \\
\hline
\end{tabular}

Fonte: Autor, adaptado de Freeman Technology, 2008. 
A energia básica de fluxo (BFE), energia despendida para deslocar a lâmina torcida no $7^{\circ}$ estágio, é calculada na transição entre o teste de estabilidade e o teste de fluxo variável. O índice de fluxo variável (FRI) é definido como relação entre a energia utilizada para movimentar a lâmina no ensaio de menor velocidade de rotação (último ponto) e a energia a utilizada para movimentar a lâmina no ensaio de maior velocidade, conforme a equação 6 (FREEMAN TECHNOLOGY, 2008).

$$
F R I=\frac{\text { energia total } \text { ensaio de menor velocidade rotação }}{\text { energia } \text { total }_{\text {ensaio de maior velocidade }}}
$$

A classificação para a fluidez segundo o Índice de Fluxo Variável é apresentada na Tabela 4.

Tabela 4 - Classificação da fluidez segundo o Índice de Fluxo Variável.

\begin{tabular}{c|l|l}
\hline FRI & \multicolumn{1}{|c}{ Classificação } & \multicolumn{1}{c}{ Possíveis causas } \\
\hline$>3,0$ & $\begin{array}{l}\text { Material altamente sensível à } \\
\text { variação de fluxo. }\end{array}$ & Material muito coesivo. \\
\hline $1,5-3,0$ & $\begin{array}{l}\text { Material sensível à variação de } \\
\text { fluxo. }\end{array}$ & Material pulverulento. \\
\hline 1 & $\begin{array}{l}\text { Material pouco ou não sensível } \\
\text { à variação de fluxo. }\end{array}$ & $\begin{array}{l}\text { Pós com elevados diâmetros médios de } \\
\text { partícula ou tratamentos de superfície. }\end{array}$ \\
\hline$<1,0$ & $\begin{array}{l}\text { Material pseudoplástico ou } \\
\text { newtoniano. }\end{array}$ & $\begin{array}{l}\text { Pós com aditivos (antiaglomerantes, } \\
\text { antiumectantes, entre outros). }\end{array}$ \\
\hline
\end{tabular}

Fonte: Autor, adaptado Freeman Technology, 2008.

\subsubsection{Teste de Compressibilidade}

O teste de compressibilidade é um processo direto e gera os parâmetros de compressibilidade (CPS expresso em \%) que é a variação percentual do volume após a compressão, e a massa específica aparente (CBD expressa em $\mathrm{g} / \mathrm{mL}$ ). O princípio desse teste é sujeitar o pó à uma série de aumento de tensões normais a fim de medir a variação de volume da amostra. A classificação para a compressibilidade é descrita na Tabela 5 e o índice de compressibilidade é calculado pela Equação 8 (FREEMAN TECHNOLOGY, 2008). 
Tabela 5 - Classificação da compressibilidade.

\begin{tabular}{c|l}
\hline Compressibilidade & \multicolumn{1}{c}{ Características } \\
\hline Baixa & $\begin{array}{l}\text { Pouca mudança no volume mesmo quando o material é submetido à } \\
\text { alta tensão normal. Excesso de ar e empacotamento de partículas } \\
\text { eficiente (porosidade mínima). Partículas de maior granulometria. } \\
\text { Normalmente material coesivo ou granular. }\end{array}$ \\
\hline Média & $\begin{array}{l}\text { Sensibilidade média para compressão. Material apresenta alguma } \\
\text { propriedade coesiva (propenão à coesão). Típico da maioria dos pós. }\end{array}$ \\
\hline Alta & $\begin{array}{l}\text { Grande mudança no volume devido à presença de ar entre as } \\
\text { partículas (alta porosidade). Pode haver formação de aglomerados. } \\
\text { Material coeso com partículas de pequena dimensão. }\end{array}$ \\
\hline
\end{tabular}

Fonte: Autor, adaptado de Freeman Technology, 2008.

$$
\text { Índice de Compressibilidade }=\frac{\text { massa específica após a compressão }}{\text { massa específica parente }}
$$

\subsubsection{Teste de Permeabilidade}

Por meio de um procedimento semelhante ao do teste de compressibilidade, os parâmetros fornecidos pelo teste de permeabilidade são a queda de pressão no leito do pó (PD), a permeabilidade $(\mathrm{k})$ e a massa específica aparente $(\mathrm{CBD} \mathrm{em} \mathrm{g} / \mathrm{mL})$. A permeabilidade mede a facilidade com que um fluido, neste caso o ar, é transmitido através do material. A classificação para a permeabilidade é apresentada na Tabela 6 (FREEMAN TECHNOLOGY, 2008).

Tabela 6 - Classificação da permeabilidade.

\begin{tabular}{c|l}
\hline Permeabilidade & \multicolumn{1}{c}{ Características } \\
\hline Baixa & $\begin{array}{l}\text { Alta pressão requerida para estabelecer o fluxo de ar através do pó. } \\
\text { Número pequeno ou limitado de canais entre as partículas. Susceptível de } \\
\text { ser um material muito coesivo com partículas pequenas. }\end{array}$ \\
\hline Média & $\begin{array}{l}\text { Perda de pressão aumentada com o aumento da compressão. Os canais } \\
\text { disponíveis para a passagem do ar diminuem em tamanho e número } \\
\text { (redução da porosidade). Típica de pós com alguma coesão e/ou com uma } \\
\text { ampla distribuição de partículas. }\end{array}$ \\
\hline Alta & $\begin{array}{l}\text { Queda de pressão mínima através do leito de pó. A compressão tem pouco } \\
\text { ou nenhum efeito sobre a permeabilidade. Partículas grandes e material } \\
\text { normalmente não coesivo ou granulares. Partículas de formato irregular } \\
\text { poderia também contribuir para a permeabilidade. Pouca mudança no } \\
\text { volume mesmo quando o material é submetido `a alta tensão normal. }\end{array}$ \\
\hline
\end{tabular}

Fonte: Autor, adaptado de Freeman Technology, 2008. 


\subsubsection{Teste de Aeração}

No teste de Aeração são obtidos a razão de aeração (AR), a energia aerada (AE) e quantificadas as alterações das propriedades de fluxo à medida que ar é introduzido na base da coluna de pó. A Figura 14 mostra um pó sensível à aeração no qual o ar é capaz de passar entre cada partícula, removendo completamente o efeito de forças mecânicas de travamento e de atrito. Cada partícula é suspensa pelo fluxo de ar e o pó torna-se suspenso em leito fluidizado.

Figura 14 - Fluidização de um material sensível à aeração.
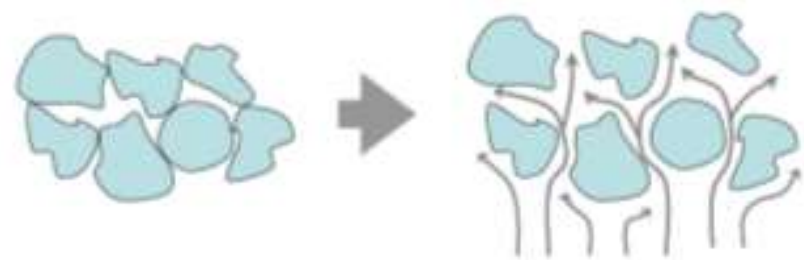

FONTE: Freeman Technology, 2008.

A Figura 15 ilustra a passagem do ar através do volume de um pó mais coeso durante um processo de aeração. As elevadas forças de coesão entre as partículas fazem com que o material forme aglomerados criando canais de ar (FREEMAN TECHNOLOGY, 2008).

Figura 15 - Fluidização de um material coesivo.
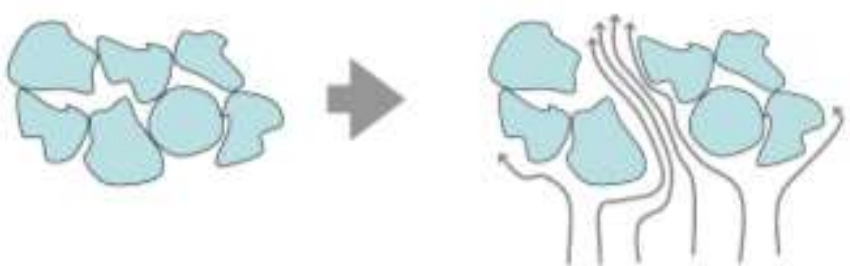

FONTE: Freeman Technology, 2008.

A energia de aeração é expressa em mili Joule (mJ) e é definida como:

Energia de Aeração = Energia para lâmina percolar o leito sob aeração

A razão de aeração de um material, calculada pela expressão 10 , é a relação entre a energia necessária para a lâmina do reômetro movimentar o leito de um material sem a introdução de ar em sua base e a energia necessária para movimentar o mesmo leito quando ele é introduzido por ar à velocidade estabelecida em um determinado teste $n$. O resultado numérico desta expressão permite classificar o material segundo a Tabela 7. 




Tabela 7 - Classificação da razão de aeração.

\begin{tabular}{c|l}
\hline Razão de Aeração & \multicolumn{1}{c}{ Características } \\
\hline 1 & $\begin{array}{l}\text { Material não é sensível à aeração. Geralmente pós muito coesos ou } \\
\text { com altos níveis de aglutinante. }\end{array}$ \\
\hline $2-20$ & Sensibilidade média à aeração. A maioria dos pós estão nesta faixa. \\
\hline$>20$ & $\begin{array}{l}\text { Material sensível ao arejamento e provavelmente torna-se em leito } \\
\text { fluidizado. Material com baixa força de coesão. }\end{array}$ \\
\hline
\end{tabular}

FONTE: Freeman Technology, 2008.

\subsubsection{Teste de Cisalhamento}

O teste de cisalhamento é a única maneira de se determinar quantitativamente a coesão de um leito de partículas, representado por unidade de tensão, associado com o somatório de todos os tipos de forças atuantes em uma partícula ou conjunto de partículas de área superficial específica. Para este conjunto de partícula se mover (fluir) é necessário que os agentes (forças) externas superem a coesão das partículas em repouso.

O teste de cisalhamento mensura a tensão tangencial de um leito de partículas (pó) consolidado a uma determinada tensão normal $(\sigma)$, obtendo-se propriedades importantes para a compreensão da facilidade com que um material inicialmente em repouso começará a fluir ou não, prevendo a formação de pontes, bloqueios e paradas nos processos industriais. A Figura 16 ilustra uma célula de cisalhamento utilizada para realização do teste em um Reômetro de pó.

Figura 16 - Célula de cisalhamento



Fonte: Autor adaptado de Freeman Technology e Schulze, 2008. 
No teste de cisalhamento ilustrado o material é inicialmente consolidado (pré-cisalhamento), posteriormente submetido à uma tensão vertical normal ( $\sigma$ ou FR) e o topo é movido a uma velocidade (v) em relação à parte inferior fixa. As partículas são movidas umas contra as outras e o atrito entre partículas resulta numa força de cisalhamento $(\tau)$ que é transferida para o topo do leito onde é medida.

No início do teste, o leito pode apresentar espaços vazios e as partículas podem mover-se mais livremente. As forças interpartículas de fricção são menos intensas e, portanto, o esforço de cisalhamento será pequeno. Com o aumento da deformação do cisalhamento, o sólido se torna cada vez mais compactado, de modo que as partículas são pressionadas umas contra as outras e as forças de fricção aumentam e o sólido é então deformado plasticamente.

$\mathrm{Na}$ medida que o experimento avança, os gráficos da massa específica aparente e do esforço de cisalhamento $(\tau)$ versus o tempo tornam-se constantes, as forças de fricção entre as partículas são totalmente mobilizadas e obtém-se a máxima força de atrito possível em relação à força normal aplicada. Assim, o fluxo ou deformação ocorre com massa específica aparente constante e é denominado fluxo de estado estacionário. É um estado bem definido e reprodutível em relação à massa específica aparente e a força de cisalhamento.

A massa específica aparente $(\rho b)$ e a tensão de cisalhamento ( $\tau$ pre) atingidas no fluxo estacionário são características da força normal aplicada em pré-curvas ( $\sigma p r e)$. Em um diagrama $\sigma, \tau$, o ponto ( $\sigma$ pre, $\tau$ pre) é chamado de ponto pré-cisalhamento e após esse ponto, o sólido é definido como consolidado crítico em relação ao estresse normal, $\sigma$. Após a consolidação pelo pré-cisalhamento, a direção do cisalhamento é invertida e o sólido é aliviado, ou seja, a tensão de cisalhamento é anulada.

A amostra consolidada fluirá quando for atingido um esforço de cisalhamento suficientemente grande para mover as partículas que se aderiram devido à consolidação anterior. O par correspondente ( $\sigma s h, \tau s h)$ é chamado de ponto de cisalhamento ou incipiente de fluxo caracterizado pelo corte de cisalhamento máximo. Em seguida, o material começará a se dilatar (diminuição da massa específica e resistência ao cisalhamento) e o esforço de cisalhamento diminuirá. A amostra é pré-cisalhada novamente sob o estresse normal, opre, depois cortado à falha, e assim sucessivamente conforme ilustrado na Figura 17. Nessas condições, a força necessária para o cisalhamento aumenta rapidamente e depois diminui, o ponto máximo dessa curva representa o início do deslizamento (SCHULZE, 2008). 
Figura 17 - Esquematização do teste de cisalhamento

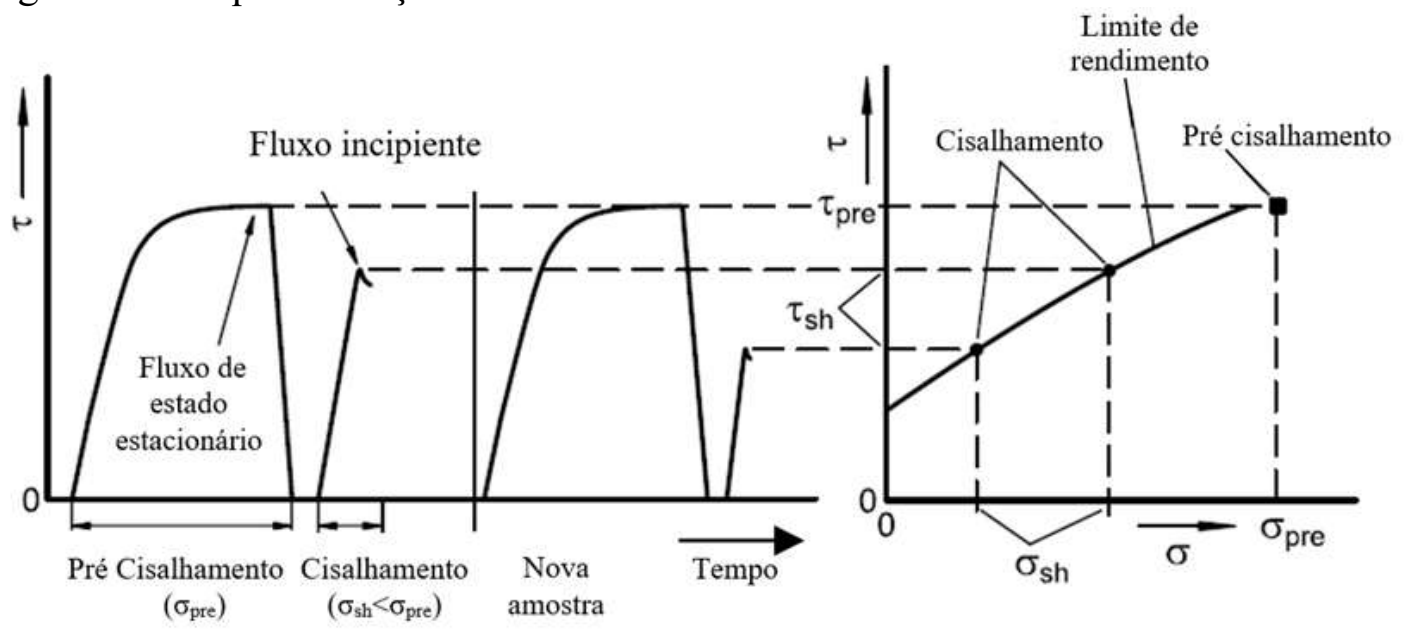

Fonte: Autor adaptado de Schulze, 2008.

O teste gera como resultado um gráfico de tensão normal versus a tensão de cisalhamento conforme o ilustrado na Figura 18. Nesse gráfico obtêm-se o Lugar Geométrico de Deslizamento (LGD ou yield locus), que representa o limite de produção de um sólido o consolidado. O locus de atrito efetivo (ELGD) é uma linha reta através da origem, tangente ao maior círculo de Mohr (fluxo de estado estacionário). Seu conhecimento permite a determinação da coesão ( $\tau c$ - valor do esforço de cisalhamento) que é obtida a partir da intersecção entre o LGD e o eixo da ordenada $(\tau)$, onde o o estresse normal é nulo $(\sigma=0)$; ângulo efetivo de fricção interna ( $\varphi$ e ou AIF) calculado a partir do arco tangente da razão de cisalhamento ao estresse normal e a relação entre a tensão de cisalhamento e a força normal e tensão não-confinada de atrito ( $f_{c}$ ou UYS) que é dada pelo limite do círculo de Mohr;

Além da massa específica aparente ( $\rho$ b ou CBD); tensão principal de consolidação $\left(\sigma_{1}\right.$ ou MPS); ângulo de fricção interna no fluxo incipiente ( $\varphi$ i); ângulo de fricção interna no fluxo estacionário ( $\varphi s f)$; ângulo de inclinação do locus de atrito linearizado ( $\varphi$ lin); tração (T ou $\sigma \mathrm{t})$ e ângulo de fricção interna no fluxo estacionário ( 
Figura 18 - Locus de atrito e propriedades de fluxo.

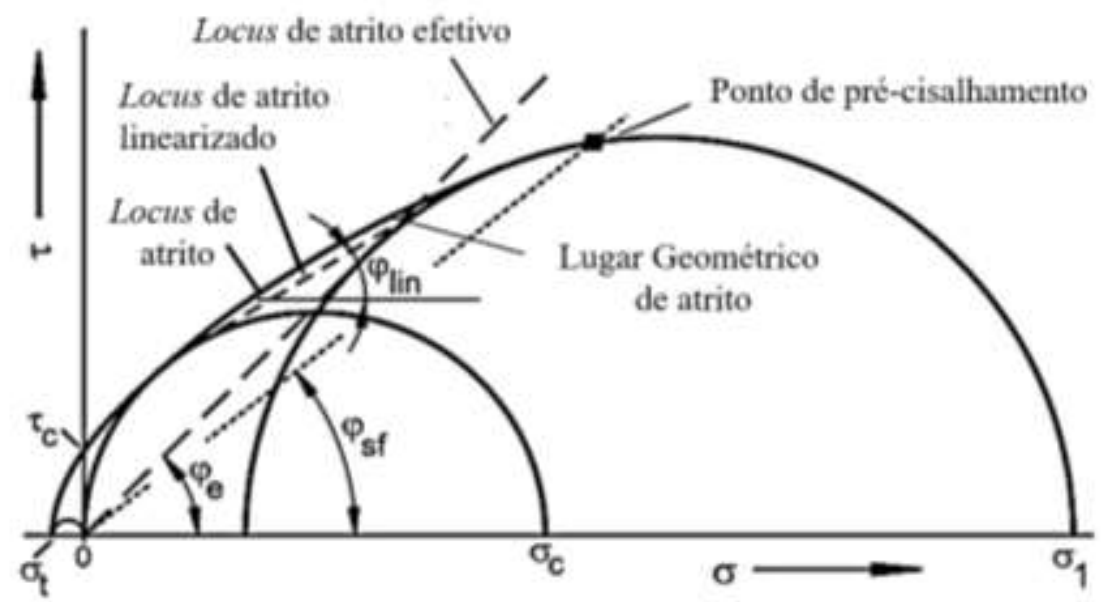

Fonte: Autor adaptado de Schulze, 2008.

Com os ensaios de cisalhamento realizados para várias tensões de pré-consolidação, têm-se várias curvas de Lugar Geométrico de Deslizamento e vários pares de pontos de tensão principal de consolidação e coesão $\left(\sigma_{1}, \sigma_{c}\right)$, podendo-se obter em um gráfico a curva da tensão inconfinada em função da tensão de consolidação $\sigma_{c}\left(\sigma_{1}\right)$, ou seja, a Função de Fluxo (FF ou $\mathrm{ff}_{\mathrm{c}}$ ) conforme o ilustrado na Figura 19 (MASCARENHAS et al., 2017).

Figura 19 - Lugar geométrico de deslizamento e função de fluxo

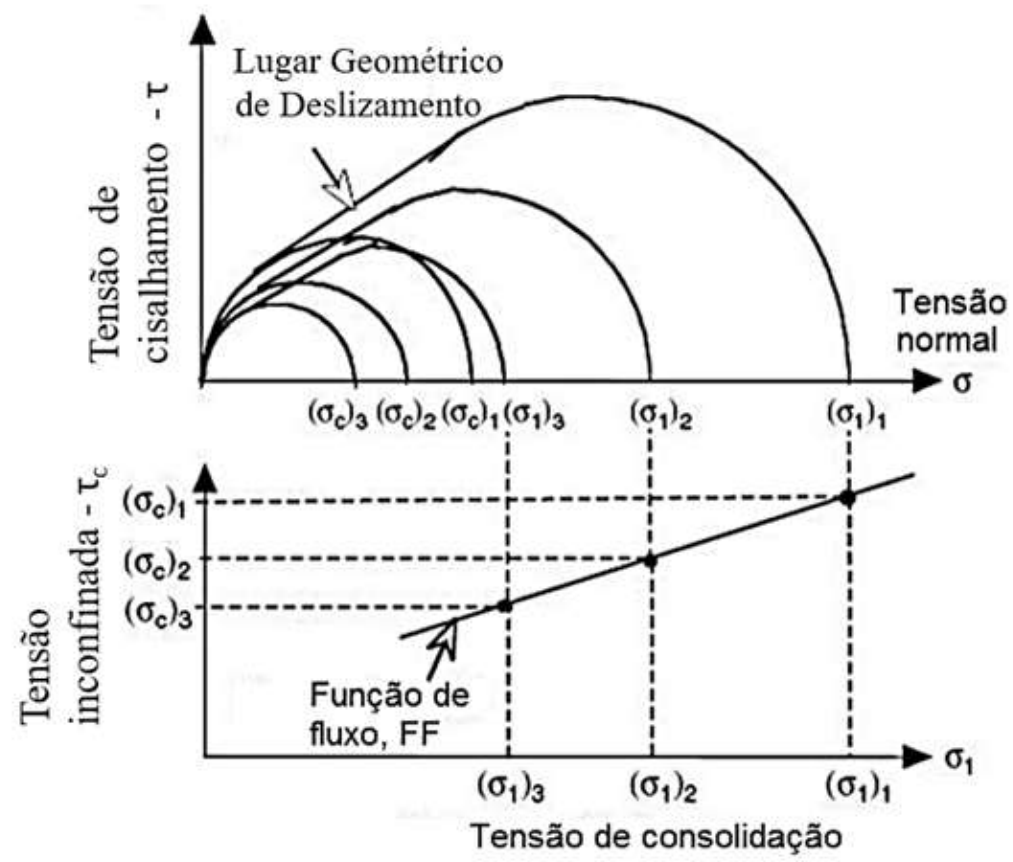

Fonte: Autor adaptado de Mascarenhas et al., 2017. 
A fluidez pode ser numericamente determinada pela função de fluxo (ffc) que é calculada conforme apresentado na Equação 20 e na Tabela 8:

$$
f f c=\frac{\sigma 1}{\sigma c}
$$

Tabela 8 - Função de fluxo

\begin{tabular}{c|c}
\hline ffc & Classificação \\
\hline$<1$ & Sem escoamento \\
\hline $1-2$ & Muito coesivo \\
\hline $2-4$ & Coesivo \\
\hline $4-10$ & Fácil escoamento \\
\hline $10<$ & Escoamento livre \\
\hline
\end{tabular}

FONTE: Autor adaptado de Schulze, 2008. 


\section{MATERIAIS E MÉTODOS}

Neste capítulo são apresentados os materiais, os equipamentos e as metodologias adotadas em cada análise.

\subsection{MATERIAIS}

Os insumos farmacêuticos analisados foram cedidos pelo Instituto de Tecnologia em Fármacos (Fiocruz/ Farmanguinhos), são eles:

- $\quad$ microcelulose 101 (MCC 101);

- $\quad$ microcelulose 102 (MCC 102);

- $\quad$ lactose monohidratada (LM);

- $\quad$ lactose spray - dried (LSD);

- $\quad$ estearato de magnésio (Mag) $\left(\mathrm{Mg}\left(\mathrm{C}_{18} \mathrm{H}_{35} \mathrm{O}_{2}\right)_{2}\right)$;

- dióxido de silício $\left(\mathrm{SiO}_{2}\right)$;

- formulações de excipientes farmacêuticos com o princípio ativo Efavirenz denominadas de amostras MCOLEFV 0414, MCOLEFV 0115, MCOLEFV 0514, MCOLEFV 0614 e MCOLEFV 0715. A composição exata dessas amostras não pode ser mencionada por questões de segredo industrial.

\subsection{EQUIPAMENTOS}

Os equipamentos utilizados pertencem aos Laboratórios de Materiais (CLM) e de Engenharia Química (CLQ) do Centro Universitário FEI utilizados são listados a seguir:

- Analisador de área de superfícial modelo Gemini VII 2390 (Micromeritics);

- Picnômetro à gás modelo AccuPyc II 1340 (Micromeritics);

- Analisador de partículas por difração à laser modelo BlueWave (MicroTrac);

- Reômetro de pó modelo FT-4 (Freeman Technology); 


\subsection{MÉTODOS}

Os métodos empregados foram selecionados para caracterizar qualitativamente e quantitativamente as amostras analisadas. Nessa sessão, é reportada a metodologia, sendo todos os experimentos realizados a pressão e temperatura ambiente (aproximadamente $1 \mathrm{~atm} \mathrm{e} 25^{\circ} \mathrm{C}$ ).

\subsubsection{Preparação das pré-misturas e amostras}

As pré-misturas de diferentes frações mássicas de MCC 101 e LM, MCC 101 e LSD, MCC 102 e LM e, MCC 102 e LSD foram nomeadas de M1, M3, M4, M6, M7, M9, M10 e M12. Na Tabela 9 é mostrado a formulação dessas oito pré-misturas base.

Tabela 9 - Detalhamento das pré-misturas base

\begin{tabular}{c|c|c|c|c}
\hline Mistura & MCC 101 (\%) & MCC 102 (\%) & LM (\%) & Lactose SD (\%) \\
\hline M1 & 40 & - & 60 & - \\
\hline M3 & 60 & - & 40 & - \\
\hline M4 & - & 40 & 60 & - \\
\hline M6 & - & 60 & 40 & - \\
\hline M7 & 40 & - & - & 60 \\
\hline M9 & 60 & - & - & 40 \\
\hline M10 & - & 40 & - & 60 \\
\hline M12 & - & 60 & - & 40 \\
\hline
\end{tabular}

Fonte: Autor adaptado de Rocha, 2017.

Após a análise das pré-misturas base, adicionou-se os excipientes estearato de magnésio (Mag) na fração mássica de $1 \%$, dióxido de silício $\left(\mathrm{SiO}_{2}\right)$ nas frações mássicas de $0,5 \%$ e $1 \%$, e estearato de magnésio com dióxido de silício nas frações mássicas de 1\% Mag com 1\% SiO2, 2\% Mag com 1\% SiO2 e 2\% Mag com 2\% SiO2 de modo que a soma da fração mássica dos constituintes da composição das pré-misturas base seja 100\%. As pré-misturas obtidas possuem fórmula geral representada pela notação $\mathbf{M x}+\mathbf{y} \% \mathbf{M a g}+\mathbf{z} \% \mathrm{SiO}_{2}$ na qual Mx representa o número da mistura base (composição básica apresentada na Tabela 9) e $y$ e $z$ as porcentagens mássicas de estearato de magnésio e dióxido de silício, respectivamente.

As pré-misturas farmacêuticas contendo princípio ativo foram formuladas a partir da variação de teores de lactose, dióxido de silício, croscamelose sódica (CMNa) e/ou manitol em uma determinada quantidade de suspensão SPEFV1 desenvolvida pela Farmanguinhos (CASTRO, 2017). A relação da formulação das pré-misturas MCOLEFV 0414, MCOLEFV 
0514, MCOLEFV 0614, MCOLEFV 0714 e MCOLEFV 0115 são apresentadas na Tabela 10 e ilustradas na Figura 20.

Tabela 10 - Detalhamento das amostras contendo princípio ativo.

\begin{tabular}{c|c|c|c|c|c|c}
\hline Numeração & Amostra & Suspensão & Lactose (g) & $\begin{array}{c}\text { Dióxido de } \\
\text { Silício (g) }\end{array}$ & $\begin{array}{c}\text { CMNa } \\
\text { (g) }\end{array}$ & $\begin{array}{c}\text { Manitol } \\
\text { (g) }\end{array}$ \\
\hline 1 & MCOLEFV 0414 & SPEFV1 & $4 \mathrm{x}$ & $\mathrm{x} / 7$ & - & - \\
\hline 2 & MCOLEFV 0514 & SPEFV1 & $2 \mathrm{x}$ & $\mathrm{x} / 14$ & $\mathrm{x} / 12$ & - \\
\hline 3 & MCOLEFV 0715 & SPEFV1 & $2 \mathrm{x}$ & $\mathrm{x} / 14$ & $\mathrm{x} / 5$ & - \\
\hline 4 & MCOLEFV 0115 & SPEFV1 & $\mathrm{x}$ & $\mathrm{x} / 14$ & $\mathrm{x} / 5$ & - \\
\hline 5 & MCOLEFV 0614 & SPEFV1 & $\mathrm{x}$ & $\mathrm{x} / 14$ & $\mathrm{x} / 5$ & $\mathrm{x}$ \\
\hline
\end{tabular}

Fonte: Autor adaptado de Castro, 2017.

Figura 20 - Amostras contendo o fármaco Efavirenz
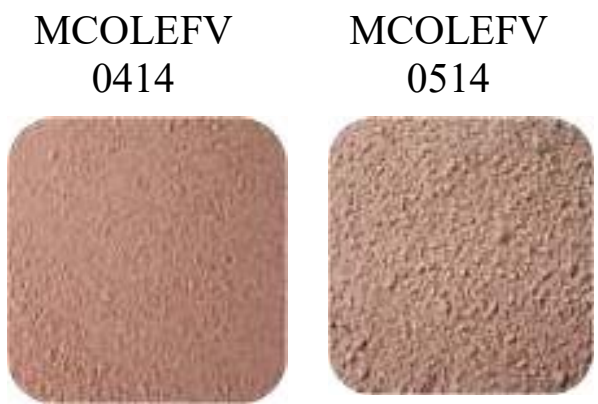

MCOLEFV

0614

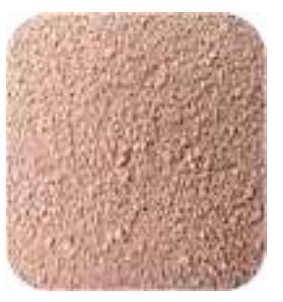

MCOLEFV

0115

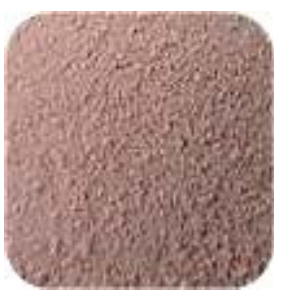

MCOLEFV

0715

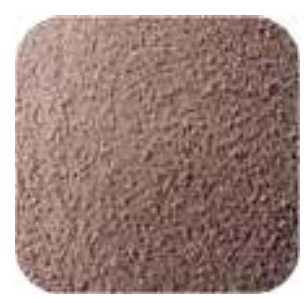

Fonte: Autor, 2018.

Dado uma determinada quantidade mássica da suspensão SPEFV1, variou-se a quantidade mássica de lactose, dióxido de silício, croscamelose sódica e manitol em função de uma massa " $x$ ". Logo a adição de croscamelose sódica pode ser avaliada comparando-se MCOLEFV 0514 com 0715, a diminuição do teor de lactose pode ser avaliada comparando-se MCOLEFV 0115 com 0715 e a substituição de uma porcentagem de lactose por manitol, comparando-se MCOLEFV 0715 com 0614.

\subsubsection{Testes estáticos}

A metodologia empregada e a preparação das amostras para cada um dos testes estáticos aplicados neste trabalho foram realizadas de acordo com o manual de cada equipamento, suscintamente explicados a seguir. 


\subsubsection{Análise de área superficial: Fissorção de $\mathrm{N}_{2}$}

A área superficial das amostras puras dos excipientes microcelulose 101, microcelulose 102, lactose monohidratada, lactose spray - dried e das pré-misturas MCOLEFV 0414, MCOLEFV 0414, MCOLEFV 0514, MCOLEFV 0614, MCOLEFV 0714 e MCOLEFV 0115 foram determinadas via isoterma de sorção de $\mathrm{N}_{2}$, segundo o método de BET (Brunauer-Emmett-Teller) com auxílio do equipamento GEMINI VII 2390, da Micromeritics. As amostras foram pesadas em tubos de vidro específicos do equipamento, secos à vácuo por $48 \mathrm{~h}$ à temperatura ambiente para eliminação da umidade e desobstrução de seus poros. Após esse período as cápsulas contendo as amostras foram acopladas no equipamento, para a obtenção das isotermas de adsorção e dessorção e obtenção da área superficial das mesmas.

\subsubsection{Análise granulométrica}

$\mathrm{O}$ analisador de tamanho de partículas por difração à laser utilizado foi o do modelo BlueWave, marca MicroTrac. Para tanto, pequenas quantidades do material foram adicionadas ao preparador de amostra e carregadas até o detector por succção (via seca) e pelo meio dispersante (via úmida). Nos métodos de via úmida evitou-se a formação de aglomerados com o uso de ultrassom e como resultado de todos os métodos empregados, o aparelho forneceu as curvas de distribuição de tamanho das partículas, expressas em volume.

A medição do diâmetro médio das partículas das pré-misturas de excipientes farmacêuticos foi realizada pelo método à seco e a análise das partículas das lactoses, das prémisturas contendo princípio ativo e do Efavirenz foi realizada pelo método via úmida, sendo etanol o meio dispersante, para se prevenir a solubilização/dissolução das partículas em água.

\subsubsection{Massas especificas: aparente e real}

A determinação da massa específica aparente condicionada (CBD - g/mL) das partículas foi realizada pelo equipamento Reômetro de Pó, modelo FT-4, da marca Freeman Technology. O cálculo dessa propriedade foi realizado automaticamente após a etapa de consolidação e split por meio do qual obteve-se o volume preciso do leito, num recipiente de calibrado, e cujo peso foi mensurado pela balança embutida no equipamento.

A massa específica real foi determinada pelo Picnômetro a gás, modelo AccuPyc II 1340, da marca Micromeritics. O princípio desse aparelho consiste em medir o volume de gás 
correspondente ao volume real das partículas (desconsiderando os poros) pela mudança de pressão observada no gás Hélio quando este se expande de uma câmara contendo a amostra

para outra câmara sem amostra. A massa da amostra é fornecida ao aparelho que realiza um total de 100 purgas a fim de remover todo o ar presente na amostra. Após 10 análises, forneceuse o valor médio da massa específica real das partículas (VASCONCELOS, 2011).

\subsubsection{Testes dinâmicos}

Os testes foram realizados pelo equipamento Reômetro de Pó, modelo FT-4, da marca Freeman Technology. A metodologia utilizada foi a descrita no manual do mesmo (FREEMAN TECHNOLOGY, 2008) e os ensaios foram realizados em duplicata, exceto o teste de cisalhamento das pré-misturas contendo o princípio ativo Efavirenz que foi realizado em triplicata (mínimo). Para as pré-misturas de excipientes farmacêuticos utilizou-se sistemas de recipientes cilíndricos de $50 \mathrm{~mm}$ de diâmetro e para as formulações farmacêuticas empregando o Efavirenz, 25 mm de diâmetro.

\subsubsection{Teste de Estabilidade e Fluxo Variável}

Para o teste de estabilidade e fluxo variável da MCC 101, MCC 102, LM, LSD e das pré-misturas de excipientes farmacêuticos foi utilizado um sistema constituído de um recipiente cilíndrico inferior com volume de $160 \mathrm{ml}$ e um recipiente superior com volume de $85 \mathrm{ml}$. O conjunto foi acoplado ao reômetro sobre uma célula de carga e tarado pelo equipamento. Com a amostra a ser analisada preencheu-se todo o reservatório inferior $(160 \mathrm{ml})$ e metade do superior $(85 \mathrm{ml})$.

Após a hélice helicoidal ser acoplada ao equipamento, o reômetro efetuou a análise, iniciando com a homogeneização da amostra. $\mathrm{O}$ excedente de amostra (conteúdo do recipiente de $85 \mathrm{ml}$ ) foi removido (split) e os exatos $160 \mathrm{ml}$ de amostra foi pesado, obtendo-se a densidade aparente da amostra. Para as formulações farmacêuticas contendo Efavirenz montou-se um sistema unindo dois recipientes com $25 \mathrm{ml}$ cada e procedimento seguiu conforme o procedimento detalhado anteriormente, porém após o split, o volume exato da mistura analisada foi de $25 \mathrm{~mL}$.

O reômetro efetuou a análise iniciando com a homogeneização da amostra e prosseguindo com o teste de estabilidade por meio da coleta de 7 medidas de energia para a lâmina percolar o leito de amostra a uma velocidade periférica constante de $10 \mathrm{~mm} / \mathrm{s}$. Ao fim 
de cada coleta, o aparelho homogeneizou a amostra e iniciou-se o teste do fluxo variável com quatro pontos. A velocidade da lâmina foi modificada para 10, 40, 70 e $100 \mathrm{~mm} / \mathrm{s}$ e os resultados deste teste geraram um gráfico da energia consumida para movimentar o material em função da velocidade de rotação da lâmina.

\subsubsection{Teste de Compressibilidade}

Para o teste de compressibilidade da MCC 101, MCC 102, LM, LSD e das pré-misturas de excipientes farmacêuticos foi utilizado um sistema constituído de dois recipientes cilíndricos com volume de $85 \mathrm{ml}$. Este conjunto foi acoplado ao reômetro sobre uma célula de carga e após a tara do sistema vazio, as pré-misturas de excipientes farmacêuticos foram adicionadas preenchendo todo o reservatório inferior e metade do superior.

A amostra foi inicialmente homogeneizada pela lâmina helicoidal. Em seguida, a lâmina foi substituída por um pistão ventilado e a amostra foi submetida a uma pré-compressão. Realizou-se o split deixando exatamente $85 \mathrm{ml}$ de amostra e o teste de compressibilidade foi iniciado submetendo as amostras às pressões de 1, 2, 4, 6, 8, 10, 12 e $15 \mathrm{kPa}$. O resultado deste teste consiste em um gráfico da pressão aplicada versus a percentagem de compressão em relação ao volume inicial de $85 \mathrm{ml}$ de amostra.

Para as formulações farmacêuticas contendo Efavirenz montou-se um sistema unindo dois recipientes cilíndricos com $25 \mathrm{ml}$ cada. O conjunto foi acoplado ao reômetro sobre uma célula de carga e procedimento seguiu conforme o procedimento detalhado anteriormente, porém após o split, o volume exato da mistura analisada foi de $25 \mathrm{~mL}$.

\subsubsection{Teste de Permeabilidade}

No teste de permeabilidade foi utilizado um sistema similar ao do teste de compressibilidade, contudo a base utilizada foi a de aeração. A calibração do volume de amostra ocorreu após a homogeneização e split da amostra, sendo que para a MCC 101, MCC 102, LM, LSD e das pré-misturas de excipientes farmacêuticos o volume foi de $85 \mathrm{~mL}$ e para as formulações farmacêuticas contendo Efavirenz, o volume foi de $25 \mathrm{~mL}$.

As amostras foram submetidas à compressão direta de 1, 2, 4, 6, 8, 10, 12 e $15 \mathrm{kPa}$, juntamente com a injeção de $2 \mathrm{~mm} / \mathrm{s}$ de ar seco na base de aeração. O resultado deste teste consistiu em um gráfico da queda de pressão através do leito de pó versus a tensão normal aplicada. 


\subsubsection{Teste de Aeração}

Para o teste de aeração foi utilizado um sistema similar ao do teste de estabilidade, porém com a injeção ar na base do recipiente. Para a construção do sistema, apenas um recipiente de $260 \mathrm{ml}$ foi utilizado para a análise da MCC 101, MCC 102, LM, LSD e das prémisturas de excipientes farmacêuticos, juntamente com a base de aeração. O sistema utilizado para as formulações farmacêuticas contendo Efavirenz foi realizado com o sistema de $35 \mathrm{~mL}$ de volume.

A base de aeração foi ligada por uma mangueira de silicone à um sistema controlador de vazão de ar comprimido. Após a tara do recipiente, adicionou-se a mesma quantidade de cada mistura utilizada no teste estabilidade de fluxo variável. O teste iniciou-se com a aeração da amostra e procedeu-se com o teste de estabilidade.

As velocidades de ar de aeração utilizadas na análise das pré-misturas de excipientes foram de $0,0,5,1,0,1,5,2,0,2,5,3,0,3,5,4,0,4,5$ e 5,0 mm/s mediante a rotação da amostra no sentido anti-horário para as velocidades de 10, 40, 70 e $100 \mathrm{~mm} / \mathrm{s}$. As velocidades de ar de aeração utilizadas nas análises das formulações farmacêuticas foram de 0,25, 0,5, 1,0, 1,5, 2,0, $2,5,3,0,3,5,4,0,4,5,5,0,5,5,6,0,6,5$ e $7,0 \mathrm{~mm} / \mathrm{s}$. O objetivo deste é verificar a redução da energia observada no teste estabilidade com a injeção de ar na amostra.

\subsubsection{Teste de Cisalhamento}

Para o teste de cisalhamento da MCC 101, MCC 102, LM, LSD e das pré-misturas de excipientes farmacêuticos foi utilizado um sistema similar ao do teste de compressibilidade e após a homogeneização da amostra, a lâmina de homogeneização foi substituída por um pistão a fim de induzir uma pré-consolidação às misturas. $\mathrm{O}$ volume da amostra analisada foi aferido pelo procedimento split e o pistão foi substituído pelo cabeçote de cisalhamento rotacional de 48 milímetros de diâmetro.

O teste iniciou-se pela aplicação de uma força normal pelo cabeçote que, posteriormente foi rotacionado induzindo uma tensão tangencial (cisalhamento) até atingir um estado estacionário. Esse procedimento foi realizado sob as tensões de consolidação de 3, 6, 9 e 15 $\mathrm{kPa}$. Para as formulações farmacêuticas contendo Efavirenz utilizou-se um sistema de recipientes de $10 \mathrm{ml}$ cada e as tensões de consolidação utilizadas foram de 3, 6 e $9 \mathrm{kPa}$.

Após atingir o regime permanente de consolidação do leito, realizou-se a determinação do local geométrico de ruptura em tensões normais inferiores à de consolidação. Para cada 
tensão de consolidação foram realizados ensaios de cisalhamento nas tensões normais de aproximadamente $35,42,5,50,57,5$ e $65 \%$ da tensão de consolidação. Desta forma foi possível obter o lugar geométrico de ruptura, os dois círculos de Morh e as tensão nomais não confinada e máxima, necessárias para a obtenção da função de fluxo e a coesão. 


\section{RESULTADOS E DISCUSSÃO}

\subsection{RESULTADOS PARA PRÉ-MISTURAS DE EXCIPIENTES FARMACÊUTICOS.}

Nesse item são apresentados os resultados das análises realizadas com as pré-misturas de excipientes farmacêuticos sem e com os agentes lubrificantes, de maneira a se estudar o efeito da adição destes às formulações farmacêuticas.

\subsubsection{Análise de Área superficial: Fissorção de $\mathrm{N}_{2}$}

A área superficial média das amostras puras precursoras das pré-misturas de excipientes farmacêuticos são apresentadas na Tabela 11 e os valores das análises individuais, no Apêndice A.

Tabela 11 - Área superficial das amostras puras precursoras das pré-misturas de excipientes

\begin{tabular}{c|c|c}
\hline Amostra & Análise & $\begin{array}{c}\text { Área superficial } \\
\left(\mathbf{m}^{2} / \mathbf{g}\right)\end{array}$ \\
\hline \multirow{2}{*}{ Lactose Monohidratada } & Média & 0,26 \\
\cline { 2 - 3 } Lactose Spray-dried & DP & 0,02 \\
\hline \multirow{2}{*}{ Microcelulose 101 } & DP & 0,11 \\
& Média & 0,00 \\
\hline \multirow{2}{*}{ Microcelulose 102} & DP & 0,72 \\
& Média & 0,01 \\
\hline
\end{tabular}

Fonte: Autor, 2018.

Constata-se que as microceluloses possuem maior área superficial do que as lactoses sendo a MCC 101 e a LM os excipientes de maior área dentre suas espécies. O processamento da lactose spray-dried reduz sua área superficial, consequentemente a adsorção de água.

\subsubsection{Análise granulométrica}

A distribuição granulométrica das amostras puras e pré-misturas são ilustradas nas Figuras 21 e 22. 
Figura 21 - Distribuição granulométrica das amostras puras precursoras das pré-misturas de excipientes

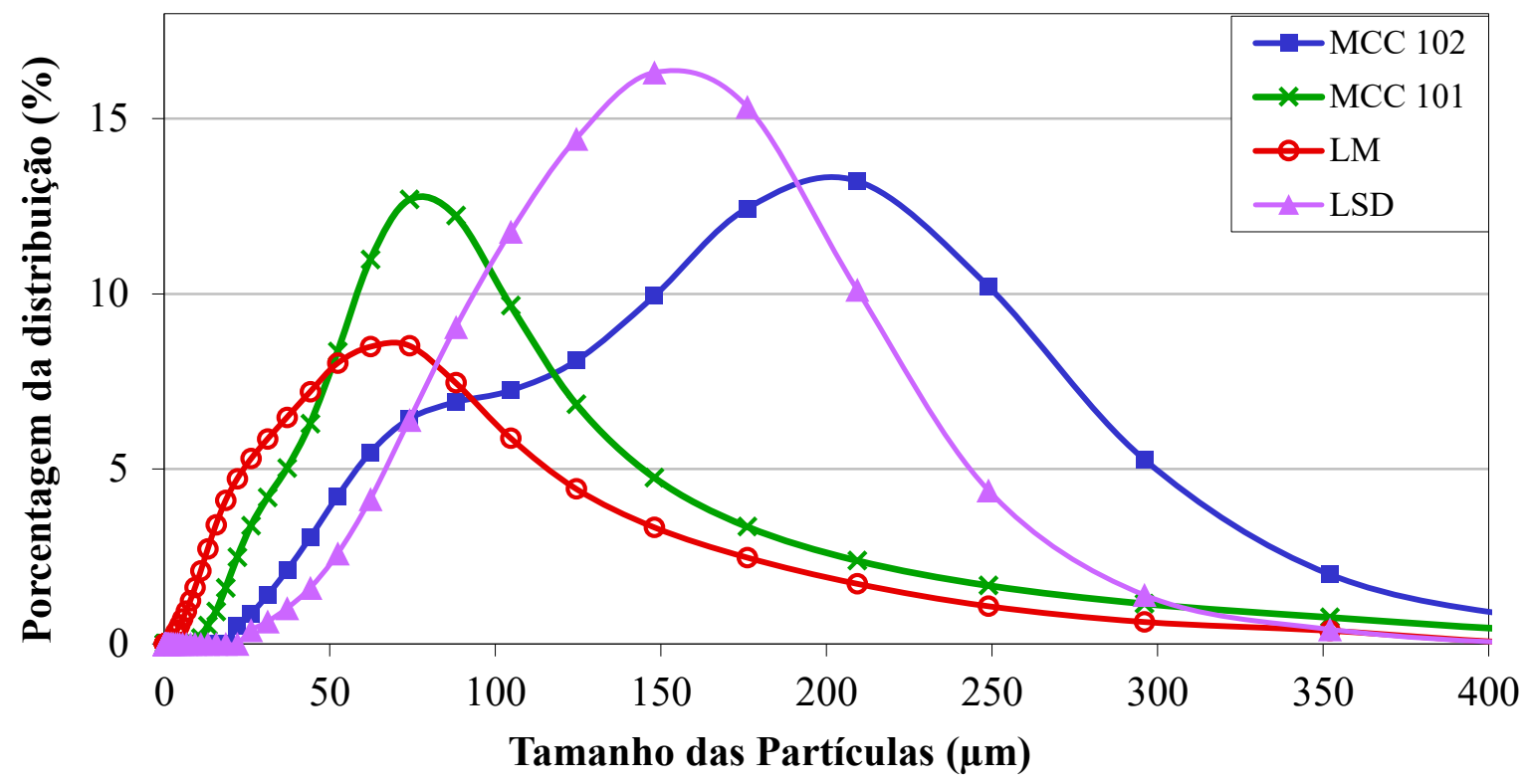

Fonte: Autor, 2018.

De acordo com a Figura 21 as amostras MCC 101 e principalmente a MCC 102 apresentam comportamento bidisperso, as demais amostras possuem comportamento monodisperso, sendo a LSD a amostra cuja faixa de distribuição granulométrica é a mais estreita. Logo a MCC 102 é a amostra cujas partículas possuem maior variação de tamanho e propensão à segregação.

Figura 22 - Distribuição granulométrica das pré-misturas base

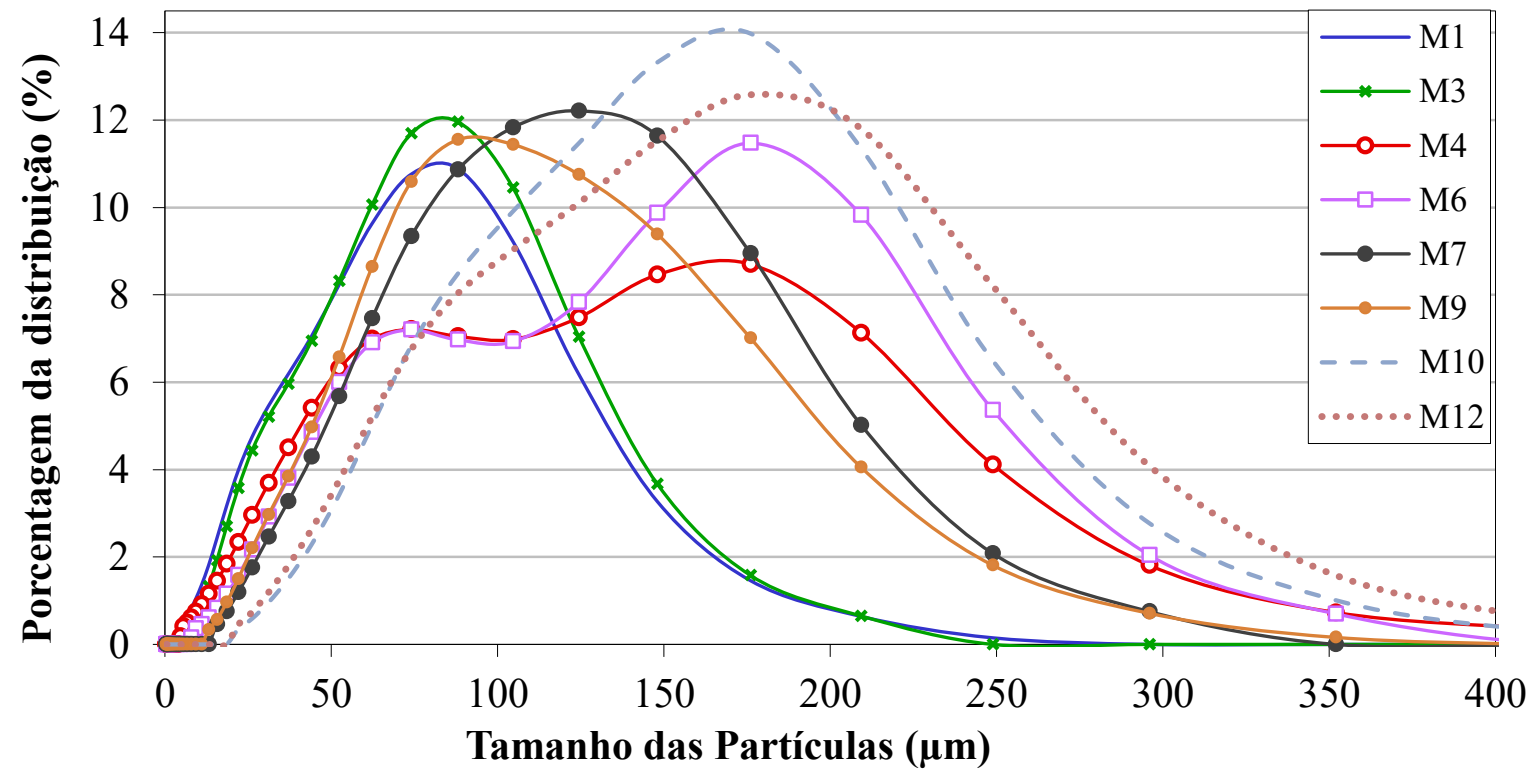

Fonte: Autor, 2018. 
Observa-se que, com exceção das pré-misturas base M7 e M9 que possuem comportamento monodispeso, as demais pré-misturas apresentam uma distribuição bastante larga, evidenciando um comportamento bidisperso para as pré-misturas M4 e M6. Os diâmetros médios volumétricos das amostras puras e das pré-misturas bases são apresentados na Tabela 12.

Tabela 12 - Diâmetro médio volumétrico das amostras puras e pré-misturas base

Fonte: Autor, 2018.

\begin{tabular}{c|c}
\hline Amostra/ Mistura & $\mathbf{d v}(\boldsymbol{\mu m})$ \\
\hline MCC 102 & 139,30 \\
\hline MCC 101 & 81,21 \\
\hline LM & 59,40 \\
\hline LSD & 125,60 \\
\hline M1 & 59,63 \\
\hline M3 & 63,28 \\
\hline M4 & 96,74 \\
\hline M6 & 109,00 \\
\hline M7 & 98,31 \\
\hline M9 & 91,40 \\
\hline M10 & 129,40 \\
\hline M12 & 133,80 \\
\hline
\end{tabular}

Segundo a Tabela 12, amostra pura de excipiente que possui o maior diâmetro é a MCC 102 e a amostra pura de menor diâmetro a LM. Essa propriedade, conforme o exposto no item 3.2, justifica a distribuição granulométrica observada anteriormente. As pré-misturas base M7 e M9 apesar de terem diâmetro menor do que as pré-misturas M10 e M12 não apresentam leitos bidispersos, com isso pré-misturas de MCC 101 e LSD demonstram ser mais homogêneas do que pré-misturas de MCC 102 e LSD. Comparando-se o comportamento de M1 e M3 (menor diâmetro) com o de M4 e M6, as pré-misturas constituídas de MCC 101 e LM são mais homogêneas do que as pré-misturas de MCC 102 e LM.

Observa-se que apesar da MCC 101 e da MCC 102 possuírem formato de lâminas finas e compridas a MCC 101 possui maior capacidade de formar uma mistura homogênea devido ao seu menor tamanho de partícula, o que desfavorece o efeito de segregação e garante a composição desejada de excipientes em uma mistura de pós após as etapas iniciais para a produção de fármacos. 


\subsubsection{Massa específica}

A massa específica real dos excipientes puros foi calculada pelo Picnômetro à gás Hélio. Já as massas específicas aparentes foram estimadas pelo Reômetro FT-4 nos testes de estabilidade e fluxo variável (EF), compressibilidade (Comp.), permeabilidade (Perm.) e cisalhamento, os quais serão apresentados posteriormente nesta seção. Entretanto, os valores das massas específicas obtidas nestes testes são apresentados na Tabela 13.

Tabela 13: Massa específica para as amostras puras precursoras das pré-misturas de excipientes

\begin{tabular}{|c|c|c|c|c|c|c|c|c|c|}
\hline \multirow{3}{*}{ Mistura } & \multirow{3}{*}{ Análise } & \multicolumn{7}{|c|}{ CDB (g/mL) } & \multirow{3}{*}{$\begin{array}{l}\rho_{\text {real }} \sim \\
(\mathrm{g} / \mathrm{mL})\end{array}$} \\
\hline & & \multirow{2}{*}{ EF } & \multirow{2}{*}{ Comp. } & \multirow{2}{*}{ Perm. } & \multicolumn{4}{|c|}{ Cisalhamento } & \\
\hline & & & & & $3 \mathrm{kPa}$ & $6 \mathrm{kPa}$ & $9 \mathrm{kPa}$ & $15 \mathrm{kPa}$ & \\
\hline \multirow{2}{*}{ MCC 102} & Média & 0,3610 & 0,3511 & 0,3564 & 0,3823 & 0,3956 & 0,3965 & 0,4678 & 1,5573 \\
\hline & DP & 0,0020 & 0,0008 & 0,0018 & 0,0007 & 0,0025 & 0,0025 & 0,0293 & 0,0041 \\
\hline \multirow{2}{*}{ MCC 101} & Média & 0,3649 & 0,3678 & 0,3677 & 0,4013 & 0,4135 & 0,4182 & 0,4287 & 1,5538 \\
\hline & DP & 0,0023 & 0,0034 & 0,0047 & 0,0005 & 0,0024 & 0,0004 & 0,0010 & 0,0055 \\
\hline \multirow{2}{*}{ LM } & Média & 0,5186 & 0,5430 & 0,5424 & 0,6392 & 0,6904 & 0,6995 & 0,7522 & 1,5399 \\
\hline & DP & 0,0052 & 0,0057 & 0,0009 & 0,0062 & 0,0007 & 0,0049 & 0,0055 & 0,0020 \\
\hline \multirow{2}{*}{ LSD } & Média & 0,6589 & 0,6558 & 0,6555 & 0,6892 & 0,6931 & 0,7276 & 0,7320 & 1,5580 \\
\hline & DP & 0,0083 & 0,0022 & 0,0044 & 0,0000 & 0,0000 & 0,0000 & 0,0023 & 0,0025 \\
\hline
\end{tabular}

Fonte: Autor, 2018.

A MCC 102 é a amostra de menor massa específica aparente e a LSD, a de maior. Observa-se um aumento dessa propriedade de acordo com o estado de consolidação do leito: quanto maior o estado de consolidação, maior a redução do volume do leito, consequentemente, maior a massa específica condicionada.

A MCC 102 apresenta maior variação da massa específica à $3 \mathrm{kPa}$ quando comparada com a massa específica à $15 \mathrm{kPa}$ prenunciando ter um leito mais poroso do que a MCC 101. A maior variação de massa específica da LM em comparação com a LSD deve-se a sua tendência coesiva em formar aglomerados internamente vazios que são desfeitos pela consolidação.

As massas específicas reais das microceluloses são iguais, o que já era esperado por serem materiais de mesma natureza química. A LSD e a LM, também constituídas de glicose, apresentam massa específica real de aproximadamente $1,6 \mathrm{~g} / \mathrm{mL}$.

A massa específica de algumas pré-misturas não pode ser calculada por não haver quantidade de amostra suficiente para realização do teste. Os resultados das pré-misturas bases 
são apresentados na Tabela 14 e no Apêndice B são apresentados os resultados de cada análise realizada para os excipientes puros e para as pré-misturas base.

Tabela 14 - Massa específica aparente para as pré-misturas de excipientes

\begin{tabular}{|c|c|c|c|c|c|c|c|c|c|}
\hline \multirow{3}{*}{$\begin{array}{c}\text { Excipiente } \\
(\%)\end{array}$} & \multirow{3}{*}{ Análise } & \multicolumn{8}{|c|}{ CDB $(\mathrm{g} / \mathrm{mL}) \mathrm{EF}$} \\
\hline & & \multicolumn{8}{|c|}{ Mistura } \\
\hline & & M1 & M3 & M4 & M6 & M7 & M9 & M10 & M12 \\
\hline \multirow{2}{*}{0} & Média & 0,4613 & 0,4344 & 0,4742 & 0,4334 & 0,4911 & 0,4443 & 0,4727 & 0,4304 \\
\hline & DP & 0,0039 & 0,0019 & 0,0011 & 0,0003 & 0,0025 & 0,0011 & 0,0003 & 0,0029 \\
\hline \multirow{2}{*}{$1 \mathrm{Mag}$} & Média & 0,4923 & 0,4513 & 0,4971 & 0,4648 & 0,5468 & 0,4837 & 0,5885 & 0,5055 \\
\hline & DP & 0,0207 & 0,0135 & 0,0206 & 0,0173 & 0,0214 & 0,0151 & 0,0118 & 0,0232 \\
\hline \multirow{2}{*}{$0,5 \mathrm{SiO} 2$} & & 0,5 & - & 19 & 224 & 0,5472 & & 0,5471 & 0,5017 \\
\hline & DP & 0,0123 & - & 0,0057 & 0,0035 & 0,0031 & 0,0012 & 0,0000 & 0,0027 \\
\hline \multirow{2}{*}{$1 \mathrm{SiO} 2$} & Média & 0,5657 & 0,5012 & - & 0,5293 & - & - & 0,5386 & 0,4952 \\
\hline & DP & 0,0080 & 0,0054 & - & 0,0041 & - & - & 0,0006 & 0,0022 \\
\hline \multirow{2}{*}{$1 \mathrm{Mag}+1 \mathrm{SiO} 2$} & Média & 0,5735 & 0,5097 & 0,5766 & 0,5065 & 0,5397 & 0,4941 & 0,5302 & 0,4785 \\
\hline & DP & 0,0070 & 0,0010 & 0,0077 & 0,0014 & 0,0026 & 0,0001 & 0,0454 & 0,0015 \\
\hline \multirow{2}{*}{$\begin{array}{l}2 \% \mathrm{Mag} \\
+1 \mathrm{SiO} 2\end{array}$} & Média & 0,5881 & 0,5256 & 0,5883 & 0,5390 & 0,5899 & 0,5379 & 0,5842 & 0,5333 \\
\hline & DP & 0,0041 & 0,0051 & 0,0148 & 0,5390 & 0,0067 & 0,0105 & 0,0143 & 0,0107 \\
\hline \multirow{2}{*}{$\begin{array}{c}2 \% \mathrm{Mag}+2 \% \\
\mathrm{SiO} 2\end{array}$} & Média & 0,5638 & 0,5062 & 0,5678 & 0,5245 & 0,5611 & 0,5127 & 0,5538 & 0,4996 \\
\hline & DP & 0,0052 & 0,0016 & 0,0080 & 0,0040 & 0,0057 & 0,0054 & 0,0105 & 0,0069 \\
\hline
\end{tabular}

Fonte: Autor, 2018.

Verifica-se na Tabela 14 que a massa específica aparente das pré-misturas base aumentam com o acréscimo de estearato de magnésio e dióxido de silício. Com isso observase que as partículas de estearato de magnésio e dióxido de silício alojam-se nos interstícios das partículas de MCC 102, MCC101, LM e LSD.

A composição de maior massa específica aparente contém $2 \%$ de estearato de magnésio e $1 \%$ de dióxido de silício em massa. Um comportamento interessante é evidenciado pelas pré-misturas base M4 e M10 que além dessa composição, apresentam maior massa específica aparente condicionada para as composições de $0,5 \%$ de dióxido de silício e $1 \%$ de estearato de magnésio, respectivamente.

\subsubsection{Estabilidade e Fluxo variável}

Os valores de energia básica de fluxo (BFE), índice de estabilidade (SI) e índice de fluxo (FRI) das amostras puras de excipientes são apresentados na Tabela 15. Os comportamentos dos excipientes puros são ilustrados na Figura 23. 
Tabela 15 - Teste de Estabilidade e Fluxo variável para as amostras puras precursoras das prémisturas de excipientes.

\begin{tabular}{c|c|c|c|c}
\hline Mistura & Análise & BFE $(\mathbf{m J})$ & SI & FRI \\
\hline \multirow{2}{*}{ MCC 102 } & Média & 1933,45 & 1,00 & 1,19 \\
& DP & 31,98 & 0,06 & 0,01 \\
\hline \multirow{2}{*}{ MCC 101 } & Média & 1293,64 & 0,98 & 1,58 \\
\cline { 2 - 5 } & DP & 28,27 & 0,02 & 0,02 \\
\hline \multirow{2}{*}{ LM } & Média & 942,07 & 1,04 & 1,61 \\
\cline { 2 - 5 } & DP & 5,30 & 0,01 & 0,02 \\
\hline \multirow{2}{*}{ LSD } & Média & 1613,13 & 1,01 & 0,99 \\
\cline { 2 - 5 } & DP & 53,67 & 0,03 & 0,01 \\
\hline
\end{tabular}

Fonte: Autor, 2018.

Figura 23 - Perfil de estabilidade e fluxo variável dos excipientes puros

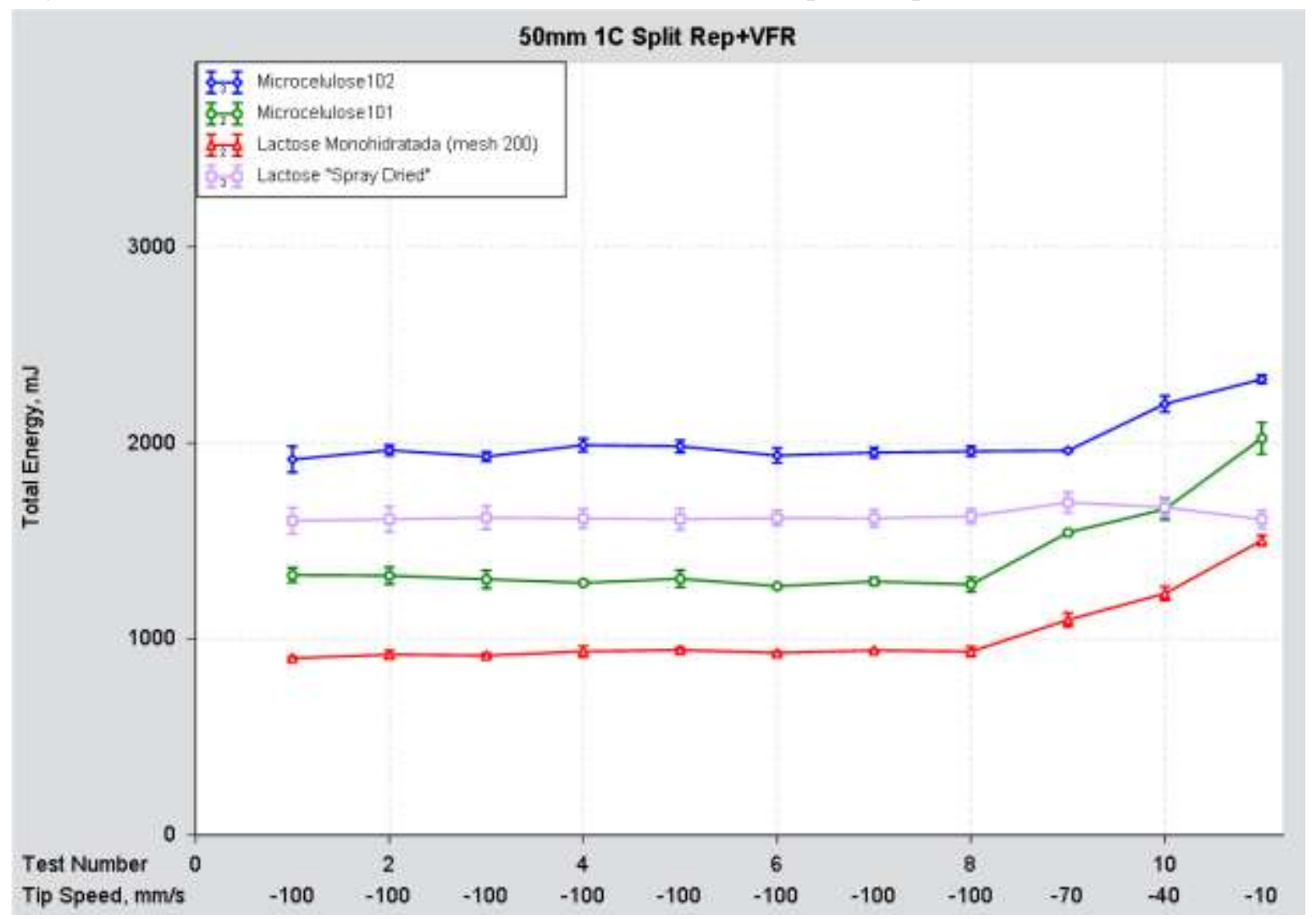

Fonte: Autor, 2018.

Com base nos resultados da Tabela 15 e na Figura 23, o perfil dos excipientes puros durante o teste de estabilidade (pontos de 1 a 7) os classifica como materiais de boa estabilidade (SI próximo de 1). Já os seus comportamentos no teste de fluxo variável (do $8^{\circ}$ ao $11^{\circ}$ ponto) 
infere à LSD um material de comportamento diferente dos demais, pois sua resistência ao escoamento não aumenta com a redução na velocidade de movimentação da lâmina

Algumas pré-misturas não foram avaliadas em todos os teores de lubrificantes pelos testes de estabilidade e fluxo variável devido à quantidade insuficiente para preencher o volume calibrado de $65 \mathrm{ml}$, devido à perda de material durante o manuseio e realização dos demais testes No intuito de ilustrar o efeito da adição de estearato de magnésio e dióxido de silício nas pré-misturas base, os valores de Energia Básica de Fluxo (BFE) e do teste de fluxo variável (VFR) da mistura base M1 são apresentados na Tabela 16 e ilustrados graficamente pela Figura 24. Os demais resultados constam no Apêndice C.

Tabela 16 - Teste de Estabilidade e Fluxo variável para pré-misturas que têm como base a mistura M1

\begin{tabular}{c|c|c|c|c}
\hline Mistura & Análise & BFE $(\mathbf{m J})$ & SI & FRI \\
\hline \multirow{2}{*}{ Mistura 1 } & Média & 1022,47 & 0,97 & 1,58 \\
\cline { 2 - 5 } & DP & 39,03 & 0,01 & 0,02 \\
\hline \multirow{2}{*}{ M1+1Mag } & Média & 448,07 & 0,81 & 1,45 \\
\cline { 2 - 5 } & DP & 3,13 & 0,12 & 0,00 \\
\hline \multirow{2}{*}{ M1+0.5 SiO2 } & Média & 1178,09 & 0,95 & 1,63 \\
\cline { 2 - 5 } & DP & 52,19 & 0,01 & 0,06 \\
\hline \multirow{2}{*}{ M1+1SiO2 } & Média & 1172,75 & 0,95 & 1,66 \\
\cline { 2 - 5 } & DP & 61,77 & 0,06 & 0,03 \\
\hline \multirow{2}{*}{ 1+1Mag+1SiO2 } & Média & 557,45 & 0,90 & 1,54 \\
\cline { 2 - 5 } & DP & 18,15 & 0,16 & 0,09 \\
\hline \multirow{2}{*}{ M1+2\% Mag+1SiO2 } & Média & 590,07 & 0,97 & 1,43 \\
\cline { 2 - 5 } & DP & 27,36 & 0,02 & 0,01 \\
\hline \multirow{2}{*}{ M1+2\% Mag+2\% } & Média & 622,15 & 0,98 & 1,53 \\
\cline { 2 - 5 } SiO2 & DP & 18,95 & 0,01 & 0,03 \\
\hline
\end{tabular}

Fonte: Autor, 2018. 
Figura 24 - Perfil de estabilidade e fluxo variável dos excipientes puros e da mistura M1 com diferentes teores de lubrificantes.

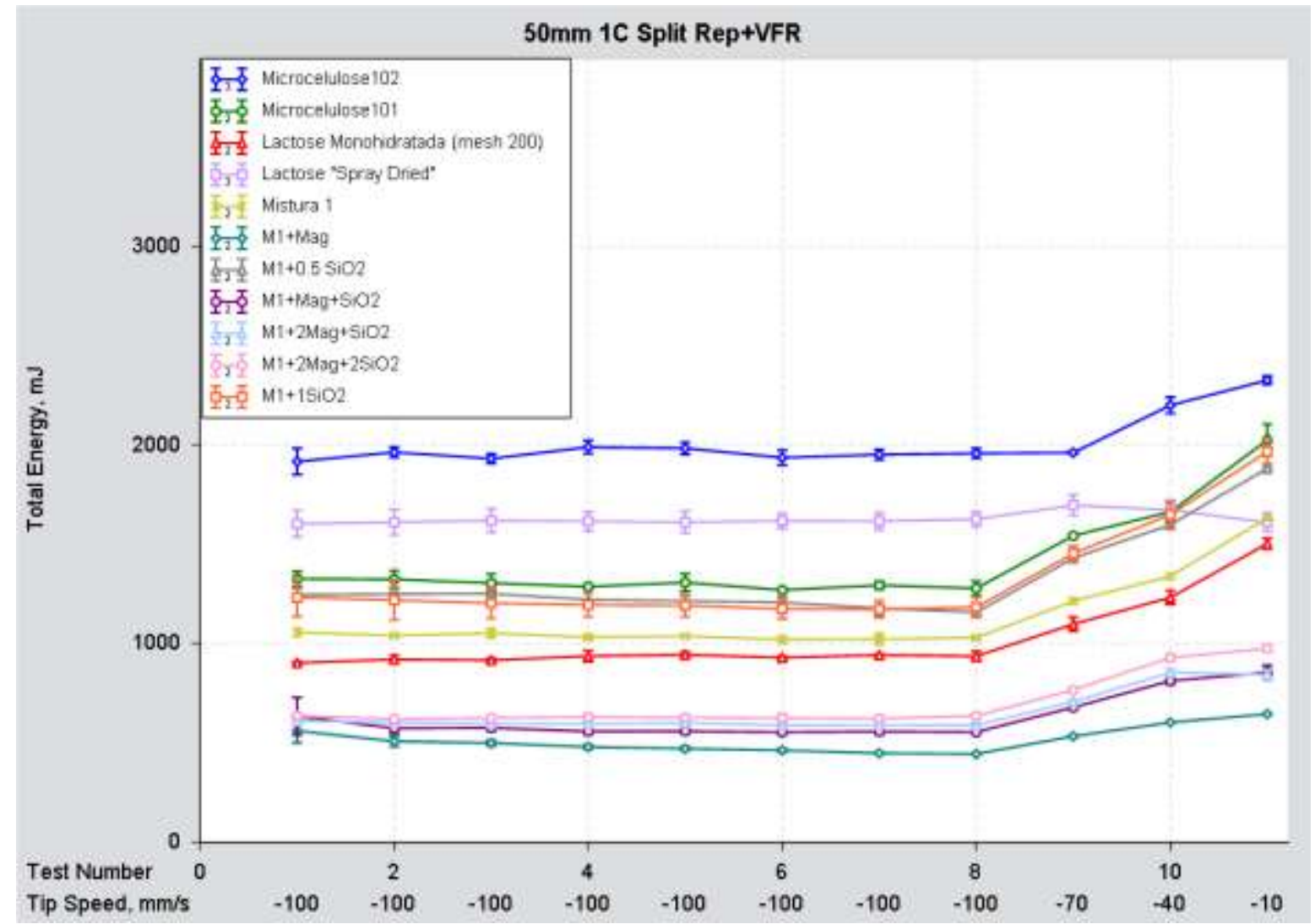

Fonte: Autor, 2018.

Observando-se os resultados para a Mistura 1 (M1) e os resultados do Apêndice C, constata-se que a adição de estearato de magnésio facilita o fluxo das pré-misturas base, pois constitui as pré-misturas com os menores BFE e SI $(\mathrm{Mx}+1 \% \mathrm{Mag})$. Já quando o dióxido de silício é adicionado na mesma quantidade (1\%), este provocou um efeito contrário, observado pela pré-mistura $\mathrm{M} 1+1 \% \mathrm{SiO}_{2}$, cujos valores de BFE e FRI aumentaram.

Para melhor compreensão dos valores de BFE obtidos por meio do primeiro teste dinâmico, assim como a importância desse parâmetro no estudo do comportamento dos sólidos particulados, o gráfico da Figura 25 ilustra o comportamento das pré-misturas de menor BFE $(\mathrm{Mx}+1 \% \mathrm{Mag})$ em relação às respectivas pré-misturas base $\mathrm{M}$. 
Figura 25 - Perfil de estabilidade e fluxo variável das pré-misturas $\mathrm{Mx}+1 \% \mathrm{Mag}$

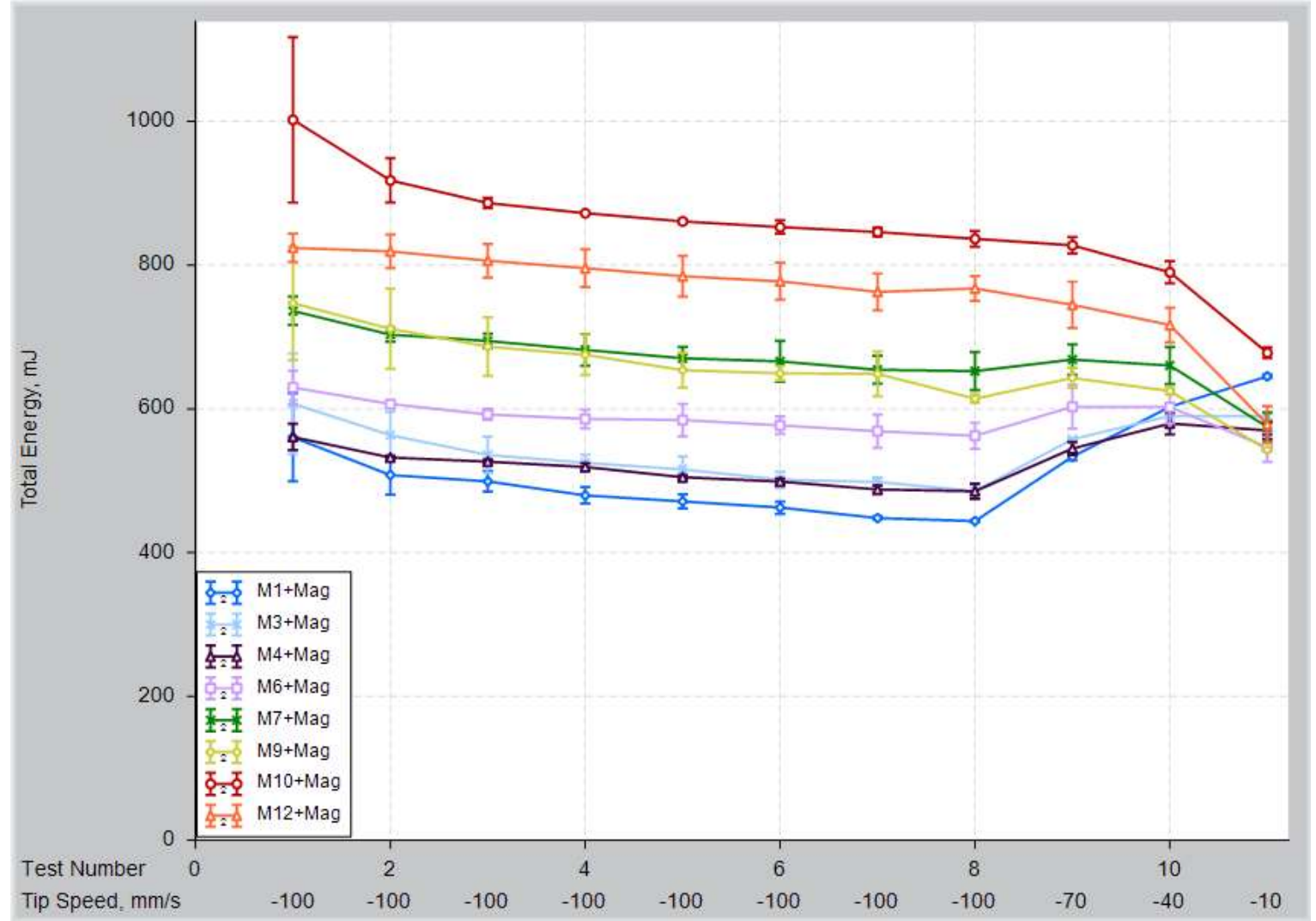

Fonte: Autor, 2018.

Os baixos valores de BFE das amostras $\mathrm{Mx}+\mathrm{y} \%$ Mag indicam que elas são menos resistentes à passagem da lâmina do Reômetro do que as demais amostras $\left(\mathrm{Mx}, \mathrm{Mx}+\mathrm{zSiO}_{2} \mathrm{e}\right.$ $\mathrm{Mx}+\mathrm{y} \% \mathrm{Mag}+\mathrm{z} \% \mathrm{SiO}_{2}$ ) ao passo que a adição de dióxido de silício torna o leito das pré-misturas mais resistente ao movimento das partículas que o constitui. Com isso, quanto menor o valor de BFE, menor energia será necessária para movimentar o leito de partículas e, consequentemente, menor será o consumo energético em um processo de movimentação (rosca, agitadores, misturadores, dentre outros) mediante a adição de estearato de magnésio em pré-misturas de lactoses monohidratada e spray-dried e microceluloses 101 e 102.

Assim, com base no gráfico da Figura 25 e nas considerações anteriores, a mistura M1+1\%Mag é destaque dentre todas as pré-misturas por ser menos resistente ao movimento físico induzido por um agente externo sob elevadas taxas de movimentação $(>100 \mathrm{~mm} / \mathrm{s})$. Porém, quando submetida a baixas taxas de movimentação $(<10 \mathrm{~mm} / \mathrm{s})$, é a mistura que apresentará maior dificuldade, juntamente com a mistura M10. Essa no entanto, será a amostra que necessitará de maior energia para ser movimentada/agitada sob qualquer velocidade. Todas as demais amostras tendem a um mesmo comportamento sob baixas taxas.

A Figura 26 apresenta o comportamento das pré-misturas contendo $0,5 \%$ em massa de dióxido de silício em relação às respectivas pré-misturas base $\mathrm{Mx}$. 
Figura 26 - Perfil de estabilidade e fluxo variável das pré-misturas $\mathrm{Mx}+\mathrm{zSiO} 2$

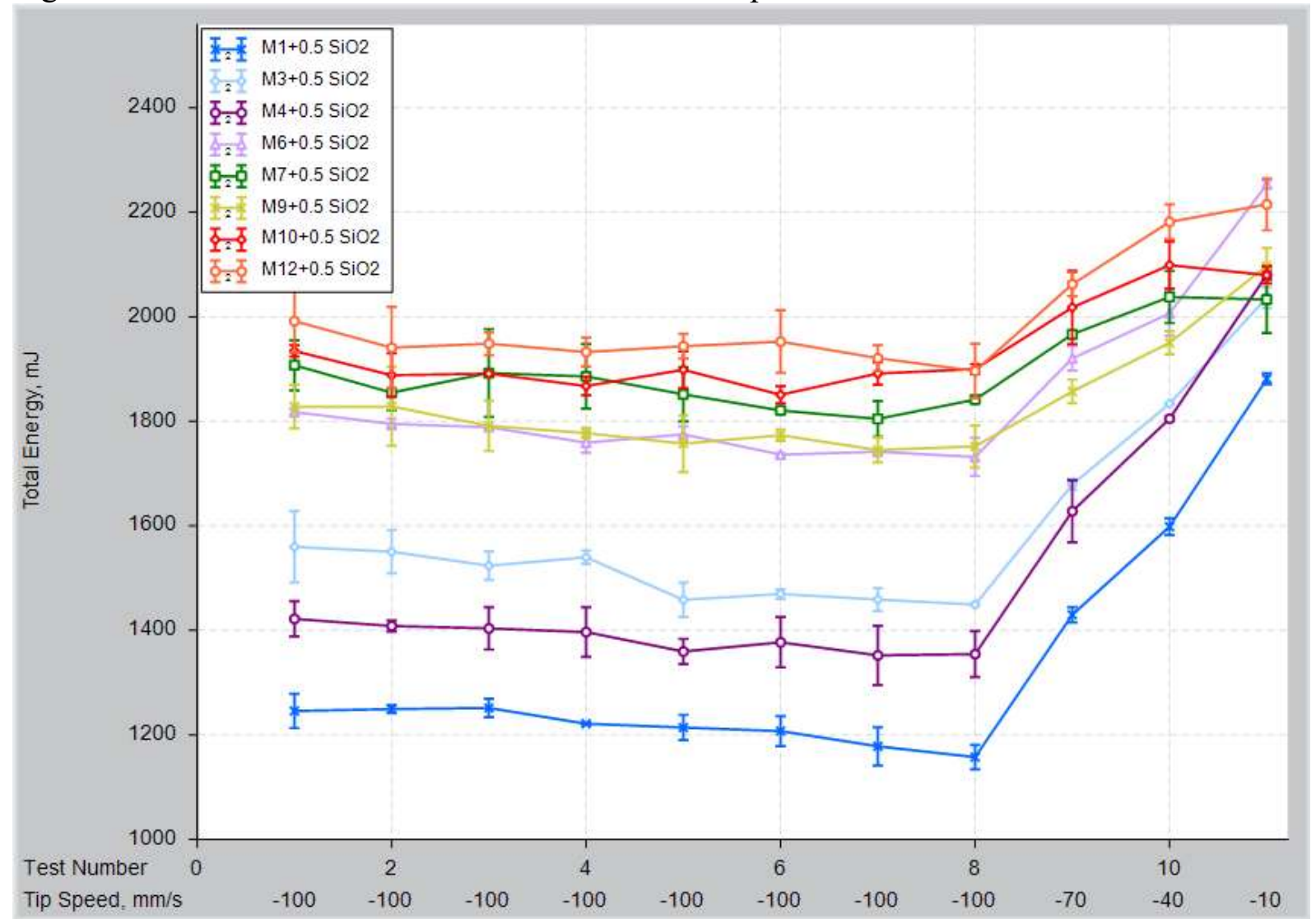

Fonte: Autor, 2018.

Analisando a Figura 26, a mistura $\mathrm{M} 1+0,5 \% \mathrm{SiO} 2$ também apresenta a menor resistência ao movimento físico induzido por um agente externo sob elevadas taxas de movimentação $(>100 \mathrm{~mm} / \mathrm{s})$ em comparação com as demais pré-misturas $\mathrm{Mx}+0,5 \% \mathrm{SiO}$. $\mathrm{E}$ apesar de não ser a mistura de maior dificuldade a baixas taxas de movimentação $(<10 \mathrm{~mm} / \mathrm{s})$, é a mistura que apresenta maior variação de energia juntamente com M4+0,5SiO2 e M3+0,5SiO2. Logo o dióxido de silício não é indicado em etapas nas quais agentes externos movimentam as pré-misturas em velocidades inferiores à $100 \mathrm{~mm} / \mathrm{s}$.

A Figura 27 apresenta o comportamento das pré-misturas de maior BFE $\left(\mathrm{Mx}+\mathrm{y} \% \mathrm{Mag}+\mathrm{z} \% \mathrm{SiO}_{2}\right)$ em relação às respectivas pré-misturas base $\mathrm{Mx}(\mathrm{M} 4, \mathrm{M} 10$ e M12). 
Figura 27 - Perfil de estabilidade e fluxo variável das pré-misturas $\mathrm{Mx}+\mathrm{y} \%+\mathrm{z} \% \mathrm{SiO}_{2}$

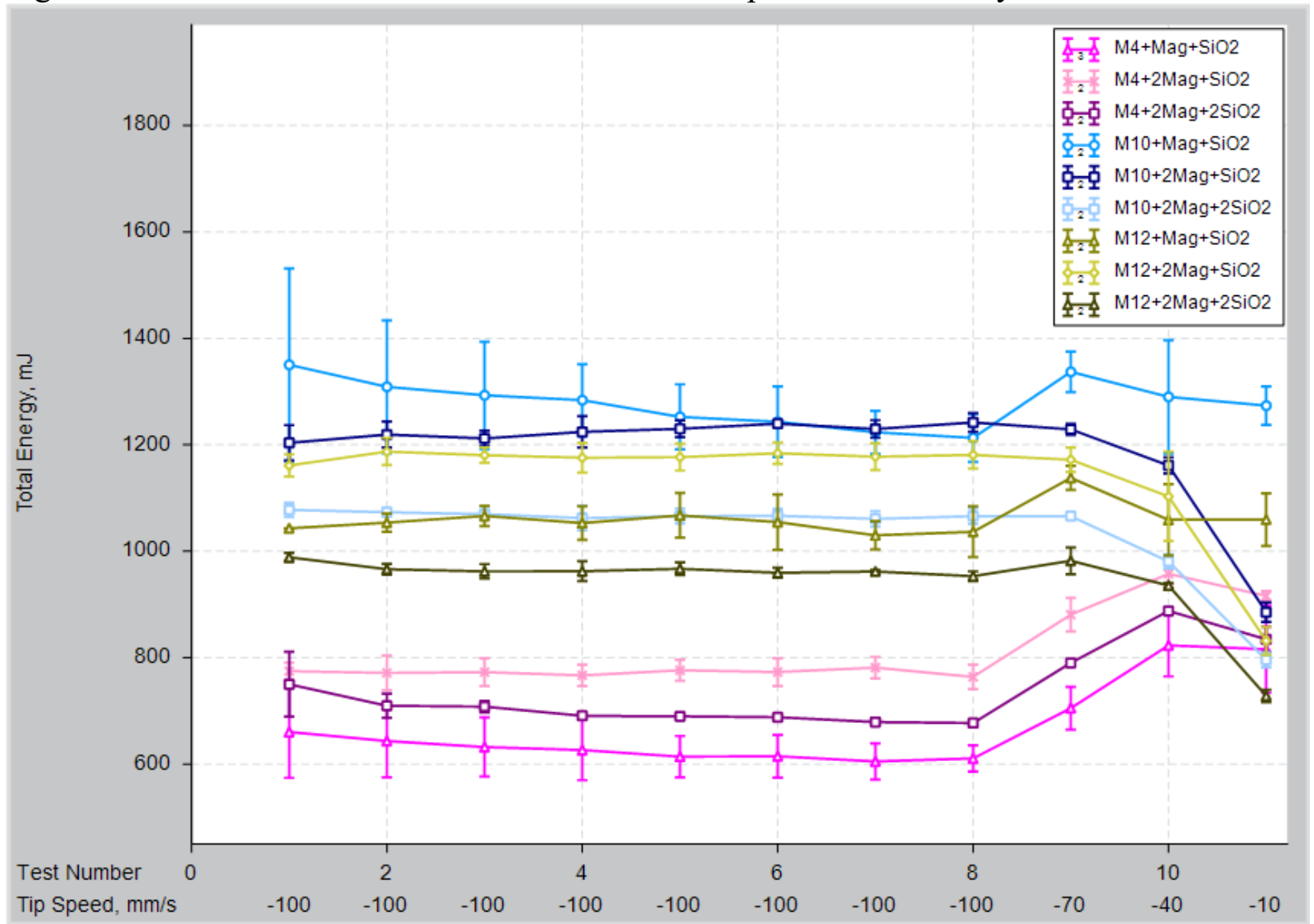

Fonte: Autor, 2018.

Conforme o ilustrado na Figura 27 a adição na proporção 2:1 de estearato de magnésio e dióxido de silício apresentou o maior BFE dentre as três proporções desses adjuvantes testadas em conjunto para todas as misturas, com exceção da mistura M1, cujo o maior BFE foi o da mistura $\mathrm{M} 1+2 \% \mathrm{Mag}+2 \% \mathrm{SiO}_{2}$. Com base nestas constatações, a adição dos dois agentes simultaneamente também não é aconselhável no que se refere à movimentação das amostras por impelidores.

Por meio do teste de estabilidade e fluxo variável verifica-se que as misturas que apresentam menor energia básica de fluxo não necessariamente fluidizam mais facilmente, mas pode indicar uma tendência coesiva das amostras que formam espaços internamente vazios. Essa suposição será confirmada com o teste de compressão e cisalhamento.

\subsubsection{Compressibilidade}

Os resultados do teste de compressibilidade para as pré-misturas puras de excipientes são apresentados na Tabela 17 e na Figura 28. 
Tabela 17 - Teste de Compressibilidade para as amostras puras precursoras das pré-misturas de excipientes

Fonte: Autor, 2018.

\begin{tabular}{c|c|c}
\hline Mistura & Análise & CPS à 15 kPa (\%) \\
\hline \multirow{2}{*}{ MCC102 } & Média & 14,09 \\
\cline { 2 - 3 } & DP & 0,33 \\
\hline \multirow{2}{*}{ MCC101 } & Média & 17,04 \\
& DP & 0,67 \\
\hline \multirow{2}{*}{ LM } & Média & 32,97 \\
& DP & 0,78 \\
\hline \multirow{2}{*}{ LSD } & Média & 7,01 \\
\cline { 2 - 3 } & DP & 0,42 \\
\hline
\end{tabular}

Figura 28 - Perfil de Compressibilidade para as amostras puras precursoras das pré-misturas de excipientes

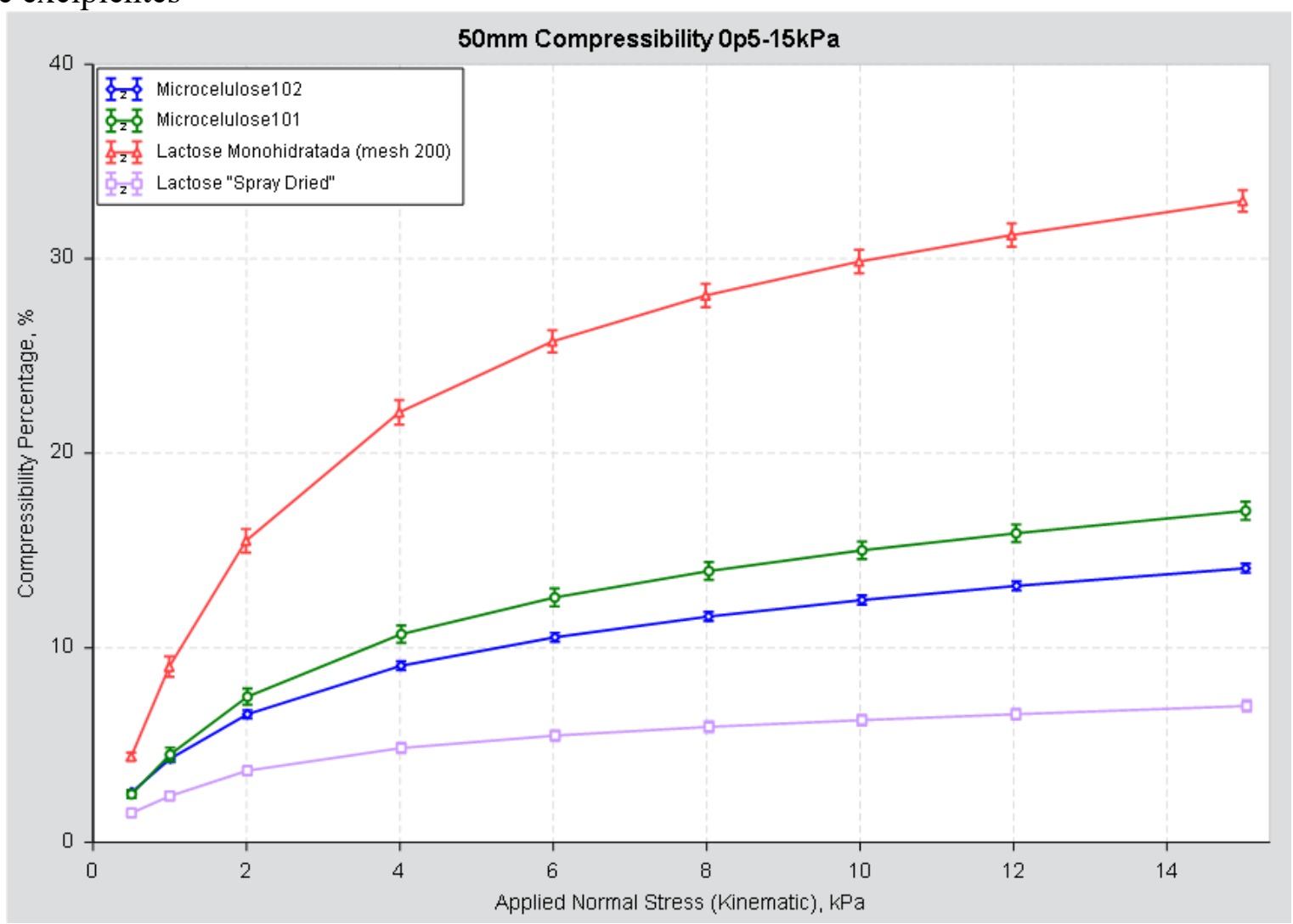

Fonte: Autor, 2018.

Observa-se que a LSD apresenta menor compressibilidade, seguida da MCC 102, MCC 101 e LM. A LSD é também a amostra de maior massa específica aparente, sendo portanto, um indicativo que suas partículas não apresentam tendência em formar aglomerados internamente vazios. Um comportamento oposto é verificado para a LM que demonstra ser a 
mais coesiva e suas partículas se acomodam de modo a formarem aglomerados internamente vazios que são desfeitos pela força de compressibilidade aplicada.

Os resultados do teste de compressibilidade para as pré-misturas base são apresentados nas Tabelas 18 e 19. Os demais resultados são apresentados no Apêndice D.

Tabela 18 - Teste de Compressibilidade para pré-misturas que têm como base M1, M3, M4 e M6

\begin{tabular}{c|c|c|c|c|c}
\hline \multirow{2}{*}{ Lubrificante } & \multirow{2}{*}{ Análise } & \multicolumn{4}{|c}{ CPS à 15 kPa (\%) } \\
\cline { 3 - 6 } & & $\mathbf{M 1}$ & M3 & M4 & M6 \\
\cline { 3 - 6 } $0 \%$ & Média & 24,24 & 19,34 & 23,49 & 19,13 \\
\cline { 2 - 6 } & DP & 1,81 & 0,96 & 2,78 & 0,11 \\
\hline \multirow{2}{*}{$1 \% \mathrm{Mag}$} & Média & 18,59 & 15,19 & 18,42 & 12,81 \\
\cline { 2 - 6 } & DP & 1,28 & 0,26 & 0,66 & 1,69 \\
\hline \multirow{2}{*}{$0.5 \% \mathrm{SiO} 2$} & Média & 8,44 & 7,41 & 7,51 & 5,97 \\
\cline { 2 - 6 } & DP & 0,11 & 0,11 & 0,34 & 0,25 \\
\hline \multirow{2}{*}{$1 \% \mathrm{SiO} 2$} & Média & 8,36 & 7,24 & 7,25 & 5,96 \\
\cline { 2 - 6 } & DP & 0,22 & 0,14 & 0,26 & 0,07 \\
\hline \multirow{2}{*}{$\% \mathrm{Mag}+1 \% \mathrm{SiO} 2$} & Média & 10,38 & 9,74 & 10,96 & 9,42 \\
\cline { 2 - 6 } & DP & 0,52 & 0,04 & 0,71 & 0,37 \\
\hline \multirow{2}{*}{$2 \% \mathrm{Mag}+1 \% \mathrm{SiO} 2$} & Média & 10,19 & 10,18 & 10,34 & 7,78 \\
\cline { 2 - 6 } & DP & 0,09 & 0,19 & 0,12 & 0,28 \\
\hline \multirow{2}{*}{ Mag $+2 \% \mathrm{SiO} 2$} & Média & 11,01 & 11,06 & 11,69 & 8,81 \\
\cline { 2 - 6 } & DP & 0,34 & 0,55 & 0,61 & 0,40 \\
\hline
\end{tabular}

Fonte: Autor, 2018.

A partir dos dados apresentados verifica-se que as pré-misturas M1 e M4 apresentam compressibilidade intermediária à compressibilidade dos excipientes que lhes originaram. A compressibilidade da mistura M3 é mais próxima da compressibilidade da MCC 101 e M6 possui compressibilidade mais próxima da MCC 102. Uma explicação para esse fenômeno em M3 e em M6 é a quebra dos aglomerados vazios da LM pelas partículas de MCC 101 (em M3) e de MCC 102 (em M6) e a formação de um leito bidisperso cujas características se aproximam do leito do adjuvante presente em maior quantidade.

Para M1, M3 e M4 o estearato de magnésio e o dióxido de silício diminuem suas compressibilidades, isto posto, o dióxido de silício é o mais eficaz nesse decréscimo, sucedido pela adição conjunta desses dois excipientes e pelo estearato de magnésio. O estearato de magnésio e o dióxido de silício também influenciam a compressibilidade de M6, contudo, a adição desses excipientes na proporção de 2:1 resulta na mistura de menor compressibilidade 
$(\mathrm{M} 6+2 \% \mathrm{Mag}+1 \% \mathrm{SiO} 2)$ entre as pré-misturas que apresentam esses dois adjuvantes em suas composições. Enquanto que para M1, M3 e M4, quanto maior a porcentagem desses adjuvantes, maior a compressibilidade da amostra.

Tabela 19 - Teste de Compressibilidade para pré-misturas que têm como base M7, M9, M10 e M12

Fonte: Autor, 2018.

\begin{tabular}{c|c|c|c|c|c}
\hline \multirow{2}{*}{ Lubrificante } & \multirow{2}{*}{ Análise } & \multicolumn{4}{|c}{ CPS à 15 kPa (\%) } \\
\cline { 3 - 6 } & & $\mathbf{M} 7$ & M9 & M10 & M12 \\
\cline { 3 - 6 } $0 \%$ & Média & 12,46 & 14,24 & 10,85 & 10,87 \\
\hline \multirow{2}{*}{$1 \% \mathrm{Mag}$} & DP & 0,57 & 0,29 & 0,12 & 0,18 \\
\hline \multirow{2}{*}{$0.5 \% \mathrm{SiO} 2$} & Média & 7,11 & 9,36 & 4,83 & 5,69 \\
\cline { 3 - 6 } & DP & 0,06 & 0,15 & 0,38 & 0,15 \\
\hline \multirow{2}{*}{$1 \% \mathrm{SiO} 2$} & Média & 4,37 & 5,32 & 3,87 & 4,25 \\
& DP & 0,44 & 0,20 & 0,15 & 0,15 \\
\hline \multirow{2}{*}{$\% \mathrm{Mag}+1 \% \mathrm{SiO} 2$} & Média & 5,04 & 5,99 & 3,66 & 4,32 \\
& DP & 0,03 & 0,00 & 0,06 & 0,20 \\
\hline \multirow{2}{*}{$2 \% \mathrm{Mag}+1 \% \mathrm{SiO} 2$} & Média & 7,25 & 8,60 & 6,33 & 6,31 \\
\hline \multirow{2}{*}{$2 \% \mathrm{Mag}+2 \% \mathrm{SiO} 2$} & Média & 0,40 & 0,64 & 0,16 & 0,02 \\
\cline { 3 - 6 } & DP & 0,42 & 0,02 & 0,01 & 0,20 \\
\hline & Média & 8,32 & 8,19 & 6,29 & 6,62 \\
\hline & DP & 0,60 & 0,41 & 0,13 & 0,31 \\
\hline
\end{tabular}

Na Tabela 19 observa-se que as pré-misturas M7 e M9 possuem compressibilidade inferiores à compressibilidade da MCC 101 e superior à da LSD. As pré-misturas M10 e M12 possuem compressibilidade intermediária à compressibilidade de seus constituintes (menor do que a da MCC 102 e maior do que a da LSD).

Para essas misturas, o estearato de magnésio e o dióxido de silício também diminuem a sua compressibilidade, e apesar do dióxido de silício ser o mais eficaz nesse decréscimo, o aumento de sua fração mássica eleva a compressibilidade quando comparada com o efeito causado pela adição de 0,5\% em massa desse mesmo excipiente em M7, M9 e M12. E assim como em M6, a adição de estearato de magnésio e dióxido de silício na proporção de 2:1 formula as pré-misturas de menor compressibilidade $(\mathrm{Mx}+2 \% \mathrm{Mag}+1 \% \mathrm{SiO} 2)$ entre as prémisturas que apresentam esses dois adjuvantes em suas composições.

Para ilustrar os comportamentos mais frequentes ocasionados pela a adição de estearato de magnésio e dióxido de silício, no gráfico da Figura 29 são apresentados o perfil de 
compressibilidade dos quatro excipientes puros e de todas as pré-misturas que têm como base a mistura M4.

Figura 29 - Perfil de compressibilidade das amostras puras e das pré-misturas originadas a partir de M4



Fonte: Autor, 2018.

No gráfico da Figura 29 é possível observar o perfil intermediário de M4 em relação à MCC 102 e à LM; o perfil das amostras que contêm estearato de magnésio e dióxido de silício; e o decréscimo da compressibilidade com a adição de dióxido de silício que atinge um patamar semelhante ao da LSD mesmo não havendo esse adjuvante na composição de M4.

Em vista que a compressibilidade está relacionada com a variação de dimensionamento que uma formulação farmacêutica pode ao ser submetida à compressão, a adição de dióxido de silício faz com que as pré-misturas de excipientes sofram menores alterações. Uma explicação para essa observação é o aprisionamento das partículas de dióxido de silício nos interstícios das partículas maiores, o que torna o meio mais resistente (aumento do BFE) e diminui a compressibilidade.

Já a adição de estearato de magnésio quando comparada com a adição de dióxido de silício, faz com que maiores forças de compressão sejam necessárias para que haja a formação 
do comprimido. Além da maior possibilidade do volume e do formato do produto final serem inferiores às dimensões especificadas. Esse fenômeno também pode prejudicar a dissolução do fármaco, uma vez que as partículas estarão mais compactadas e consequentemente, as forças interparticulares serão intensificadas.

\subsubsection{Permeabilidade}

Os resultados do teste de permeabilidade das amostras puras de excipientes são apresentados na Tabela 20 e na Figura 30.

Tabela 20 - Teste de Permeabilidade para as amostras puras precursoras das pré-misturas de excipientes

Fonte: Autor, 2018.

\begin{tabular}{c|c|c}
\hline Mistura & Análise & PD à $\mathbf{1 5} \mathbf{k P a}(\mathbf{m B a r})$ \\
\hline \multirow{2}{*}{ MCC102 } & Média & 1,13 \\
\cline { 2 - 3 } & DP & 0,05 \\
\hline \multirow{2}{*}{ MCC 101 } & Média & 2,62 \\
\cline { 2 - 3 } & DP & 0,02 \\
\hline \multirow{2}{*}{ LM } & Média & 17,50 \\
& DP & 0,50 \\
\hline \multirow{2}{*}{ LSD } & Média & 1,93 \\
& DP & 0,01 \\
\hline
\end{tabular}


Figura 30- Perfil de Permeabilidade para as amostras puras precursoras das pré-misturas de excipientes

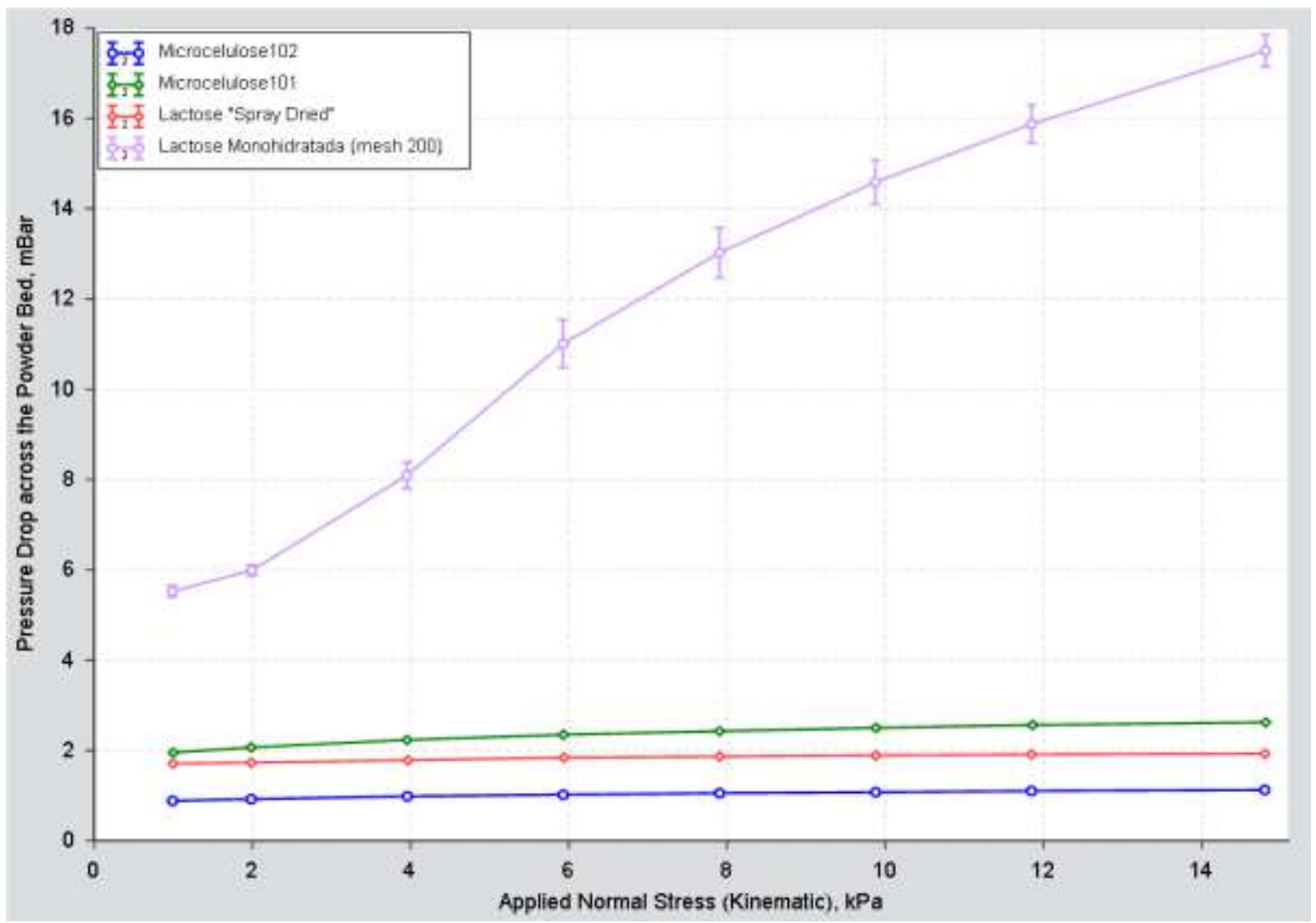

Fonte: Autor, 2018.

Verifica-se que a LM é a amostra de maior queda de pressão, seguida pela MCC 101, LSD e MCC 102. Essa estruturação revela a ordenação decrescente de pressão requerida para que o fluxo de ar seja estabelecido através do leito dessas amostras, consequentemente a LM apresenta uma tendência mais coesiva e a MCC 102, menos coesiva.

Os resultados do teste de permeabilidade para as pré-misturas base de excipientes são apresentados na Tabela 21. Os demais resultados são apresentados no Apêndice E. 
Tabela 21 - Teste de Permeabilidade para pré-misturas base

\begin{tabular}{|c|c|c|c|c|c|c|c|c|c|}
\hline \multirow{3}{*}{ Lubrificante $(\%)$} & \multirow{3}{*}{ Análise } & \multicolumn{8}{|c|}{ PD à $15 \mathrm{kPa}$ (mBar) } \\
\hline & & \multicolumn{8}{|c|}{ Mistura } \\
\hline & & M1 & M3 & M4 & M6 & M7 & M9 & M10 & M12 \\
\hline \multirow{2}{*}{$0 \%$} & Média & 8,54 & 5,45 & 6,79 & 3,75 & 2,35 & 2,47 & 1,26 & 1,27 \\
\hline & DP & 0,04 & 0,01 & 0,42 & 0,04 & 0,01 & 0,02 & 0,02 & 0,02 \\
\hline \multirow{2}{*}{1 Mag } & Média & 14,06 & 8,18 & 13,16 & 6,28 & 5,63 & 4,80 & 3,46 & 3,17 \\
\hline & DP & 0,36 & 0,03 & 0,58 & 0,03 & 0,12 & 0,13 & 0,07 & 0,02 \\
\hline \multirow{2}{*}{$0.5 \mathrm{SiO} 2$} & Média & 1,03 & 1,10 & 1,37 & 1,20 & 3,37 & 3,48 & 2,10 & 2,23 \\
\hline & DP & 0,27 & 0,11 & 0,18 & 0,09 & 0,06 & 0,19 & 0,03 & 0,01 \\
\hline \multirow{2}{*}{$1 \mathrm{SiO} 2$} & Média & 1,17 & 7,18 & 10,53 & 5,19 & 3,20 & 3,42 & 2,16 & 2,23 \\
\hline & DP & 0,24 & 0,10 & 0,09 & 0,12 & 0,02 & 0,12 & 0,05 & 0,05 \\
\hline \multirow{2}{*}{$1 \mathrm{Mag}+1 \mathrm{SiO} 2$} & Média & 15,61 & 9,93 & 14,92 & 6,76 & 4,07 & 4,50 & 2,19 & 2,19 \\
\hline & DP & 0,30 & 0,13 & 0,12 & 0,04 & 0,04 & 0,03 & 0,03 & 0,00 \\
\hline \multirow{2}{*}{$\begin{array}{c}2 \mathrm{Mag}+1 \\
\mathrm{SiO} 2\end{array}$} & Média & 1,00 & 9,68 & 1,04 & 6,55 & 4,36 & 4,57 & 2,52 & 2,34 \\
\hline & DP & 0,35 & 0,12 & 0,24 & 0,07 & 0,22 & 0,09 & 0,07 & 0,05 \\
\hline \multirow{2}{*}{$\begin{array}{c}2 \mathrm{Mag}+2 \\
\mathrm{SiO} 2\end{array}$} & Média & 0,66 & 0,86 & 15,75 & 7,22 & 4,58 & 5,39 & 2,95 & 3,01 \\
\hline & DP & 0,13 & 0,07 & 0,08 & 0,03 & 0,61 & 0,64 & 0,06 & 0,03 \\
\hline
\end{tabular}

Fonte: Autor, 2018.

Considerando a adição do estearato de magnésio (1\%Mag) e de dióxido de silício (1\% $\mathrm{SiO}_{2}$ ), verifica-se na Tabela 21 que as pré-misturas apresentaram dois tipos de comportamentos. O primeiro é ilustrado no gráfico da Figura 31, e o segundo no gráfico da Figura 32. 
Figura 31 - Perfil de Permeabilidade da mistura M4



Fonte: Autor, 2018.

Figura 32 - Perfil de Permeabilidade da mistura M9

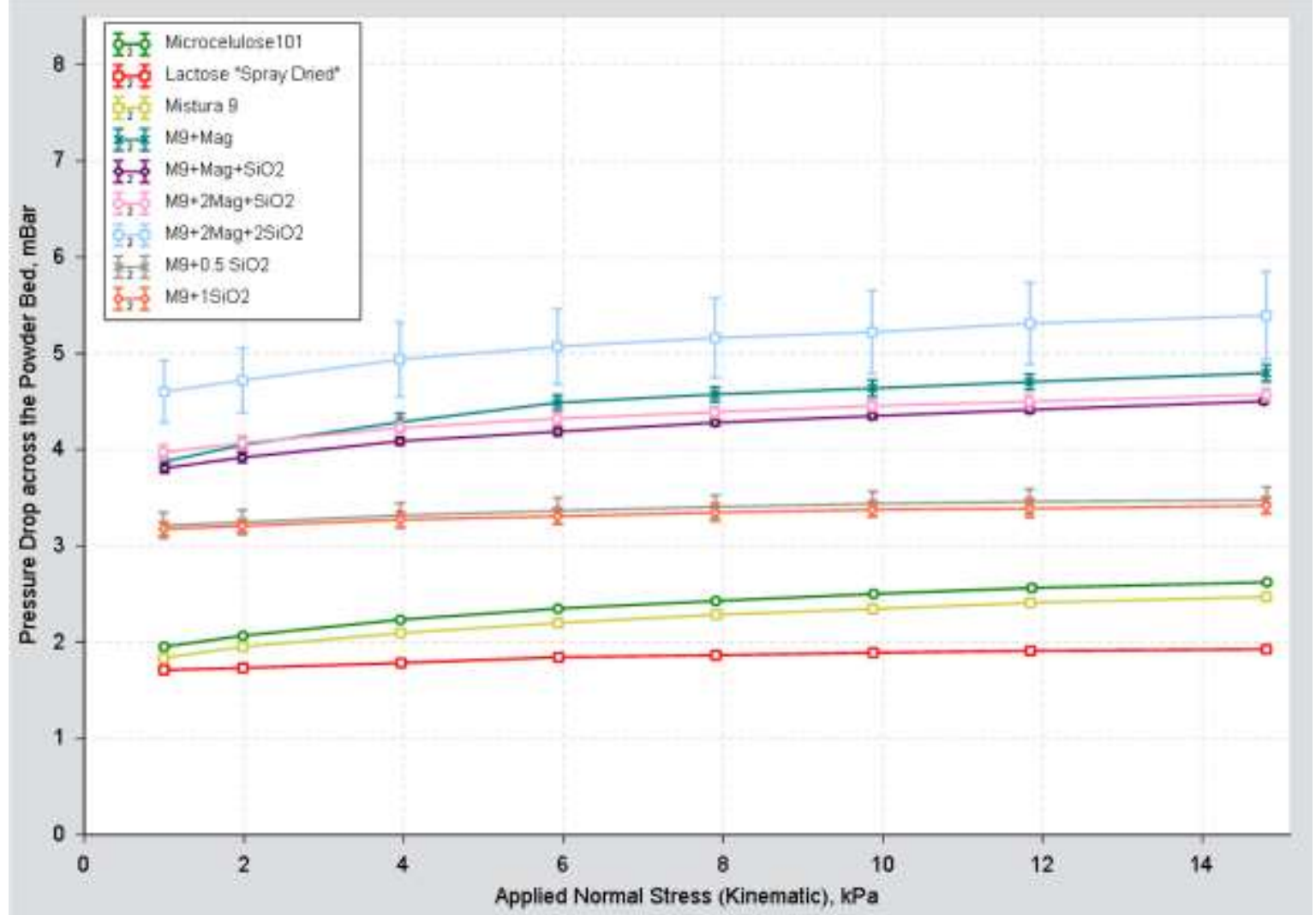

Fonte: Autor, 2018. 
No primeiro comportamento (Figura 31), para as pré-misturas que possuem queda de pressão superior à 2,4 mmBar (M1, M3, M4 e M6) os excipientes afetam sua permeabilidade, sendo o Mag o menos eficaz e o $\mathrm{SiO} 2$ na fração mássica de $0,5 \%$, o mais eficaz melhorando essa propriedade. A adição de dióxido de silício com estearato de magnésio nas proporções de 2:1 e 2:2, 2:2 e 2:1 tornam M1, M3 e M4 mais permeáveis, respectivamente. No segundo comportamento (Figura 32), as pré-misturas que possuem queda de pressão inferiores à 3,0 mmBar (M7, M9, M10 e M12), os excipientes pioram suas permeabilidades.

Uma vez que a permeabilidade está relacionada com o processo de desaeração do leito, quanto menor a perda de carga e maior a permeabilidade do leito, a desaeração do leito ocorre mais rápido e consequentemente, etapa de compressão também pode ser realizada em velocidades maiores. Ao passo que um leito de baixa permeabilidade pode ter ar aprisionado entre suas partículas durante a etapa de compressão e que pode expandir causando o efeito capping no produto final após o alívio da tensão aplicada.

Em vista do exposto, apenas o dióxido de silício quando adicionado na fração mássica de 0,5 \% nas pré-misturas base M1, M3, M4 e M6 e a adição de dióxido de silício com estearato de magnésio nas proporções de 2:1 e 2:2, 2:2 e 2:1 tornam M1, M3 e M4 menos propensas ao efeito capping.

\subsubsection{Aeração}

Os resultados do teste de aeração das amostras puras de excipientes são apresentados na Tabela 22 e Figura 33.

Tabela 22 - Teste de Aeração para as amostras puras precursoras das pré-misturas de excipientes

\begin{tabular}{c|c|c|c}
\hline Mistura & Análise & AE 3,5 (mJ) & AR 3,5 \\
\hline \multirow{2}{*}{ MCC101 } & Média & 201,17 & 6,49 \\
\cline { 2 - 4 } & DP & 7,51 & 0,17 \\
\hline \multirow{2}{*}{ MCC102 } & Média & 470,15 & 4,32 \\
\cline { 2 - 4 } & DP & 11,07 & 0,19 \\
\hline \multirow{2}{*}{ Lactose "Spray Dried" } & Média & 553,59 & 2,46 \\
\cline { 2 - 4 } & DP & 18,23 & 0,40 \\
\hline \multirow{2}{*}{ LM (mesh 200) } & Média & 204,78 & 3,97 \\
\cline { 2 - 4 } & DP & 13,05 & 0,35 \\
\hline
\end{tabular}

Fonte: Autor, $20 \overline{18 .}$ 
Figura 33 - Perfil de Aeração para as amostras puras precursoras das pré-misturas de excipientes

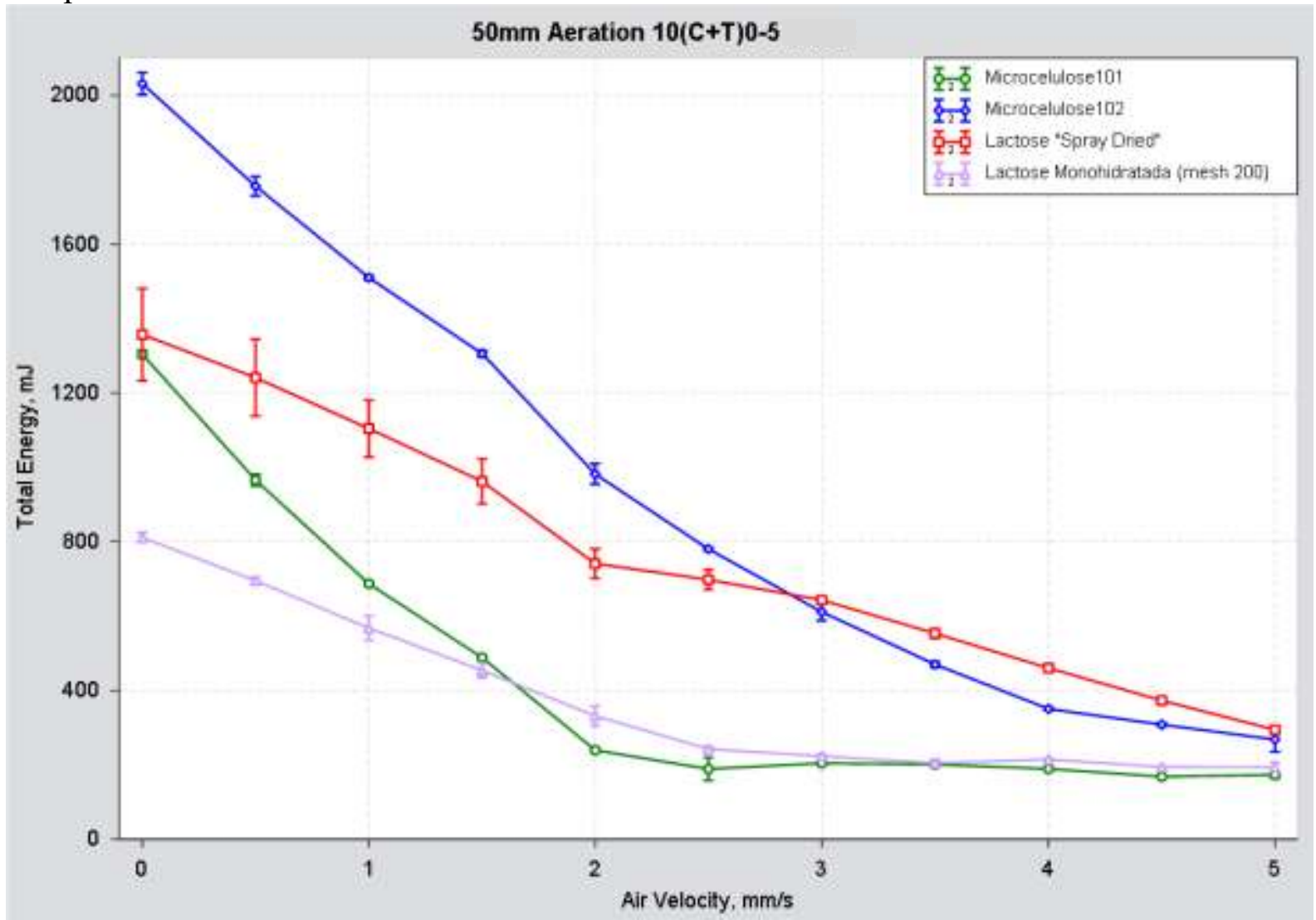

Fonte: Autor, 2018

Com base na Figura 33, as amostras não atingem o patamar de zero no estado de estabilidade e o perfil de fluidização estabelecido é do tipo agregativo no qual se fluidizam não as partículas individualmente, mas um conjunto aglomerados com poros isolados (espaços vazios). A presença de aglomerados no sistema indica a existência interação entre as partículas mesmo após o regime de fluidização ter sido estabelecido, o que requerer mais energia para movimentar a lâmina através desse sistema.

Apesar das amostras de MCC 101 e LM apresentarem esse perfil de aeração, elas atingem a estabilidade (redução nos valores de energia) para baixas velocidades do ar, o que é explicado pela maior quantidade de aglomerados que não permitem a passagem de ar através deles e que, por serem mais leves (relação massa/volume), fluidizam com menor vazão.

Os resultados do teste de aeração para as pré-misturas de excipientes são apresentados nas Tabelas 23 e 24. Os demais resultados são apresentados no Apêndice F. 
Tabela 23 - Energia de aeração para pré-misturas de excipientes

\begin{tabular}{|c|c|c|c|c|c|c|c|c|c|}
\hline \multirow{2}{*}{$\begin{array}{c}\text { Excipiente } \\
(\%)\end{array}$} & \multirow{2}{*}{ Análise } & \multicolumn{8}{|c|}{$\mathrm{AE}_{3,5}(\mathrm{~mJ})$} \\
\hline & & M1 & M3 & M4 & M6 & M7 & M9 & M10 & M12 \\
\hline & Média & 185,56 & 199,49 & 220,67 & 224,63 & 154,94 & 189,89 & 317,59 & 387,08 \\
\hline & DP & 22,01 & 4,19 & 8,62 & 24,91 & 10,64 & 15,48 & 27,00 & 30,43 \\
\hline \multirow{2}{*}{$1 \mathrm{Mag}$} & Média & 95,44 & 116,99 & 102,13 & 108,83 & 19,49 & 36,81 & 13,96 & 16,02 \\
\hline & $\mathrm{DP}$ & 18,58 & 3,00 & 6,09 & 11,94 & 4,85 & 7,98 & 2,49 & 3,32 \\
\hline \multirow{2}{*}{$0,5 \mathrm{SiO} 2$} & Média & 78,88 & 62,18 & 75,62 & 66,69 & 26,61 & 22,01 & 98,48 & 76,47 \\
\hline & DP & 34,68 & 16,11 & 14,32 & 33,47 & 0,02 & 0,98 & 3,65 & 5,82 \\
\hline \multirow{2}{*}{$1 \mathrm{SiO} 2$} & Média & 43,17 & - & 61,36 & 54,78 & 25,74 & 17,40 & 113,91 & 89,76 \\
\hline & DP & 12,20 & - & 21,04 & 4,88 & 2,91 & 2,94 & 2,32 & 4,58 \\
\hline \multirow{2}{*}{$\begin{array}{c}1 \mathrm{Mag}+1 \\
\mathrm{SiO} 2\end{array}$} & Média & 71,56 & 34,55 & 54,66 & 39,67 & 23,02 & 25,47 & 78,03 & 55,61 \\
\hline & DP & 8,58 & 6,90 & 33,05 & 3,38 & 4,41 & 3,38 & 0,95 & 1,65 \\
\hline \multirow{2}{*}{$\begin{array}{c}2 \mathrm{Mag}+1 \\
\mathrm{SiO} 2 \\
\end{array}$} & Média & 46,33 & 25,24 & 81,85 & 27,68 & 14,80 & 16,43 & 45,74 & 35,84 \\
\hline & DP & 20,43 & 7,19 & 47,95 & 5,67 & 1,02 & 0,49 & 3,94 & 4,19 \\
\hline \multirow{2}{*}{$\begin{array}{c}2 \mathrm{Mag}+2 \\
\mathrm{SiO} 2\end{array}$} & Média & 52,09 & 69,02 & 73,53 & 45,35 & 19,43 & 27,24 & 40,16 & 31,40 \\
\hline & DP & 11,80 & 13,11 & 62,38 & 0,45 & 1,68 & 0,45 & 2,04 & 0,33 \\
\hline
\end{tabular}

Fonte: Autor, 2018.

Tabela 24 - Relação de aeração para pré-misturas de excipientes

\begin{tabular}{|c|c|c|c|c|c|c|c|c|c|}
\hline \multirow{2}{*}{$\begin{array}{c}\text { Excipiente } \\
(\%)\end{array}$} & \multirow{2}{*}{ Análise } & \multicolumn{8}{|c|}{ AR 3,5 } \\
\hline & & M1 & M3 & M4 & M6 & M7 & M9 & M10 & M12 \\
\hline \multirow{2}{*}{0} & Média & 4,32 & 5,17 & 3,37 & 3,61 & 5,13 & 4,70 & 2,26 & 2,62 \\
\hline & DP & 0,45 & 0,34 & 0,05 & 0,04 & 0,85 & 0,91 & 0,05 & 0,09 \\
\hline \multirow{2}{*}{$1 \mathrm{Mag}$} & Média & 3,48 & 3,58 & 3,38 & 4,35 & 31,43 & 16,80 & 53,12 & 39,03 \\
\hline & DP & 0,15 & 0,12 & 0,16 & 0,11 & 4,70 & 1,65 & 4,10 & 8,18 \\
\hline \multirow{2}{*}{$0,5 \mathrm{SiO} 2$} & Média & 15,43 & 23,59 & 18,81 & 32,31 & 73,34 & 84,87 & 21,65 & 25,87 \\
\hline & DP & 6,71 & 6,27 & 3,86 & 17,70 & 0,48 & 1,29 & 2,02 & 5,23 \\
\hline \multirow{2}{*}{$1 \mathrm{SiO} 2$} & Média & 30,50 & - & 25,82 & 35,40 & 69,93 & 101,06 & 15,80 & 20,88 \\
\hline & $\mathrm{DP}$ & 8,29 & - & 8,97 & 1,78 & 5,64 & 21,42 & 0,31 & 0,08 \\
\hline \multirow{2}{*}{$\begin{array}{c}1 \mathrm{Mag}+1 \\
\mathrm{SiO} 2\end{array}$} & Média & 10,29 & 20,94 & 17,28 & 22,58 & 44,20 & 31,47 & 18,19 & 17,01 \\
\hline & DP & 0,27 & 3,77 & 9,30 & 2,44 & 4,67 & 3,36 & 2,74 & 0,80 \\
\hline \multirow{2}{*}{$\begin{array}{c}2 \mathrm{Mag}+1 \\
\mathrm{SiO} 2\end{array}$} & Média & 17,10 & 28,96 & 12,97 & 37,91 & 91,21 & 61,10 & 29,80 & 35,52 \\
\hline & DP & 10,05 & 8,09 & 7,18 & 1,15 & 8,58 & 1,65 & 3,48 & 3,85 \\
\hline \multirow{2}{*}{$\begin{array}{c}2 \mathrm{Mag}+2 \\
\mathrm{SiO} 2\end{array}$} & Média & 12,29 & 9,11 & 14,97 & 19,62 & 51,33 & 31,10 & 28,32 & 32,92 \\
\hline & DP & 2,27 & 2,07 & 12,54 & 1,38 & 1,76 & 0,04 & 1,45 & 0,81 \\
\hline
\end{tabular}

Fonte: Autor, 2018.

Segundo o exposto por Freeman (2006), quanto maior a razão de aeração e menor a energia de aeração (AE), menos o pó é coesivo, com isso, a adição de 1\% em massa de dióxido de silício torna as pré-misturas M1, M4 e M9 menos coesivas conforme o observado nas Tabelas 23 e 24. A diminuição das forças interparticulares de M3, M6 e M7 é ocasionada pela 
adição de estearato de magnésio com dióxido de silício 2:1 em massa e a melhor fluidização das pré-misturas M10 e M12 é ocasionada pelo estearato de magnésio 1\% em massa.

Porém essa relação proposta por Freeman (2006) não pode ser aplicada à LSD e MCC 102, as quais devem ter seu perfil de aeração analisado juntamente com outras propriedades. As partículas da LSD e MCC 102, por serem maiores e apresentarem a maior massa específica consolidada, requerem maiores velocidade do ar para fluidizarem e atingirem o patamar de estabilidade nulo, pois esse patamar só é atingido quando o leito estiver totalmente fluidizado, o que requer maiores velocidades do ar para partículas mais densas conforme apresentado no Apêndice F.

Considerando apenas os valores numéricos obtidos no teste de aeração, esses excipientes seriam caracterizados como materiais coesivos, ao passo que uma investigação mais detalhada do perfil de aeração juntamente com os dados de massa específica e índices obtidos no teste de estabilidade e fluxo variável os caracterizam como materiais de fluxo fácil.

Em relação à relação de aeração das pré-misturas de excipientes, mais uma vez a adição de dióxido de silício $1 \%$ em massa é evidenciado, pois as pré-misturas possuem relação de aeração superior à 20 , o que lhes caracterizam como pré-misturas sensíveis ao arejamento e de baixa força de coesão. As pré-misturas formuladas a partir de M7, M10 e M12 apresentam comportamento mais interessante na velocidade de $3,5 \mathrm{~mm} / \mathrm{s}$, na qual todas as misturas, inclusive $\mathrm{Mx}+1 \% \mathrm{Mag}$, possuem relação de aeração superiores à 20. Como as pré-misturas $\mathrm{Mx}+1 \% \mathrm{Mag}+1 \% \mathrm{SIO}_{2}$ são facilmente fluidizadas na velocidade de 3,5 mm/s, essa vazão e composição são aconselhadas em operações como secagem e fluidização.

O gráfico apresentado na Figura 34 ilustra a facilidade de fluidização ocasionada pela a adição de excipientes a uma mistura coesiva caracterizada pela fluidização produzida à elevadas energias de aeração, M10. 
Figura 34 - Perfil de aeração das amostras puras e das pré-misturas originadas a partir de M10

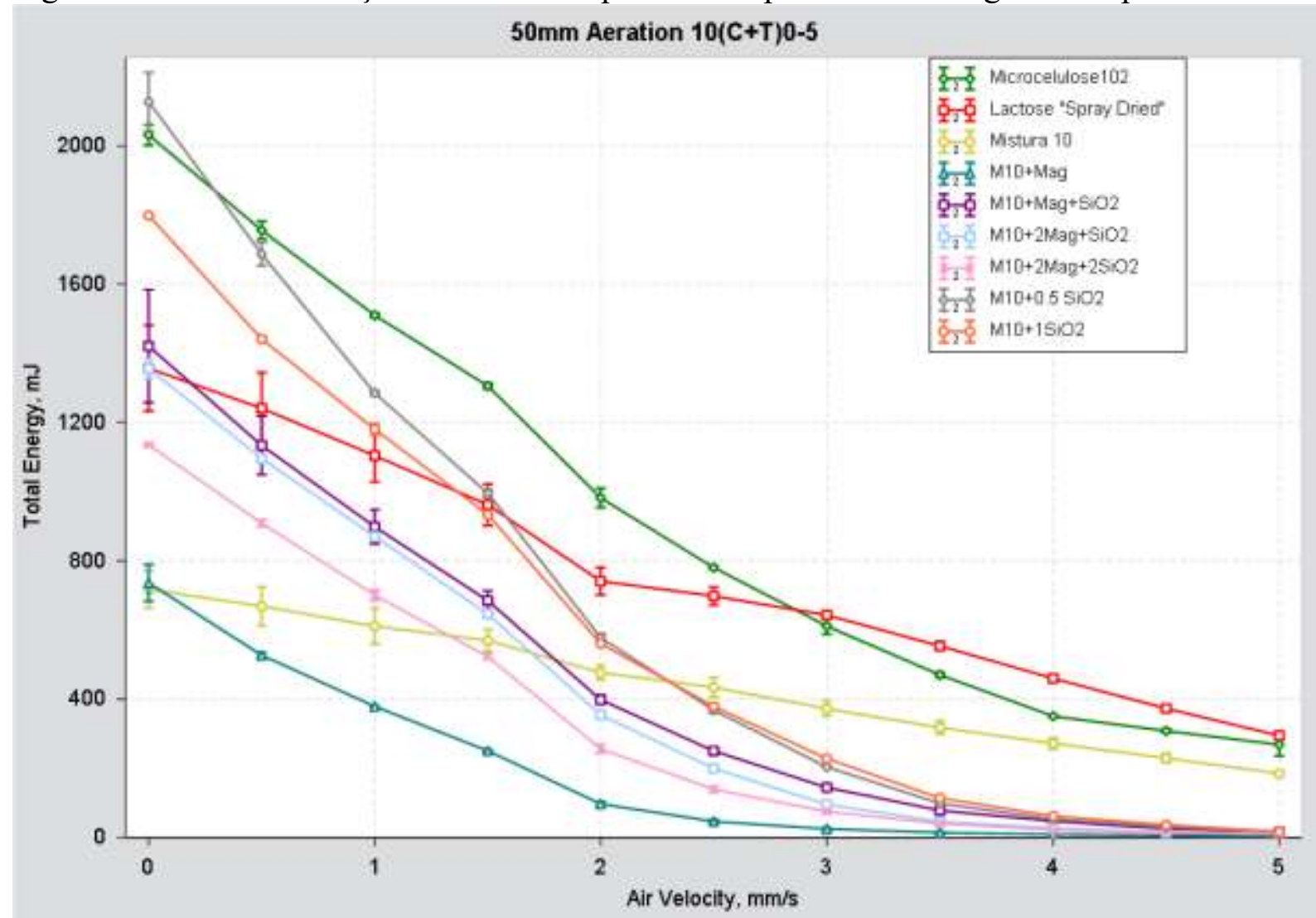

Fonte: Autor, 2018.

Observa-se que em presença de estearato de magnésio e dióxido de silício o leito das misturas, no caso M10, são totalmente fluidizados uma vez que atingem um patamar de estabilidade em 0 mJ. Esse fenômeno também ocorre para M6, M7 e M12.

\subsubsection{Cisalhamento}

Os resultados do teste de cisalhamento das amostras de excipientes puros são apresentados nas Figuras 35 e 36. 
Figura 35- Coesão à 3, 6, 9 e $15 \mathrm{kPa}$ para as amostras puras precursoras das pré-misturas de excipientes

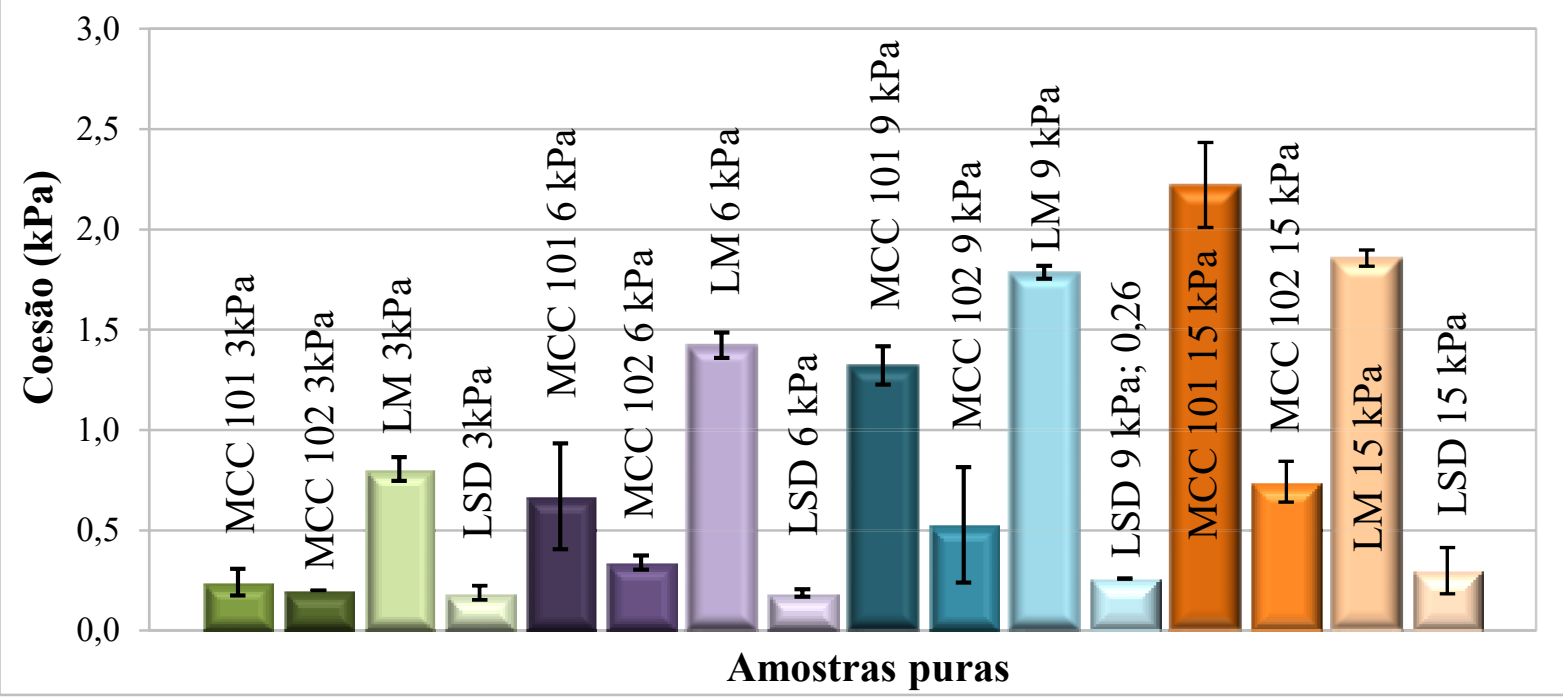

Fonte: Autor, 2018.

Observa-se na Figura 35 que o aumento da coesão das amostras puras é proporcional à tensão de consolidação aplicada com destaque para LM e LSD, por apresentarem respectivamente as maiores e menores coesões dentre as amostras. Considerando apenas as microceluloses, a MCC 102 é menos coesiva do que a MCC 101.

Com base nesses resultados solidifica-se a particularidade de cada um dos excipientes puros analisados. A LSD é um material não coesivo, de superfície lisa e uniforme que constitui um leito menos poroso de baixa compressibilidade. O peso das partículas dessa lactose confere uma maior resistência dependendo do modo com que os agentes externos atuam, por isso possui BFE elevado e baixa permeabilidade e relação de aeração.

Devido a coesividade da LM grandes forças são requeridas para que haja a quebra de todas as forças interparticulares desse material. Contudo essa propriedade faz com que uma partícula se una a outra partícula antes de completar seu percurso delineado pela ação da gravidade, ocorrendo assim, a formação de aglomerados internamente vazios. A presença de ar nos espaços vazios confere uma menor resistência do meio, o que justifica os baixos índices de BFE e RA e alta compressibilidade e permeabilidade.

A MCC 101 é o segundo excipiente de maior coesividade e têm suas características esclarecidas de acordo com o especificado para a LM. A MCC 102 é a amostra cuja a coesão é a segunda menor e têm suas propriedades de fluxo definidas conforme o definido para a LSD, porém a diferença do tamanho e da morfologia das partículas desses dois excipientes justifica alguns índices serem controversos. 
Com isso as partículas de MCC 102, por terem formato de lâmina, sofrem travamento mecânico; o que explica o BFE da MCC 102 ser maior do que o da LSD e seu leito, ser o menos permeável. Logo a etapa de secagem da LSD e da MCC 102 assim como a saída desses excipientes de equipamentos como o misturador são mais fáceis do que as mesmas etapas quando envolvem LM e MCC 101.

Figura 36 - Função de Fluxo das amostras puras precursoras das pré-misturas de excipientes

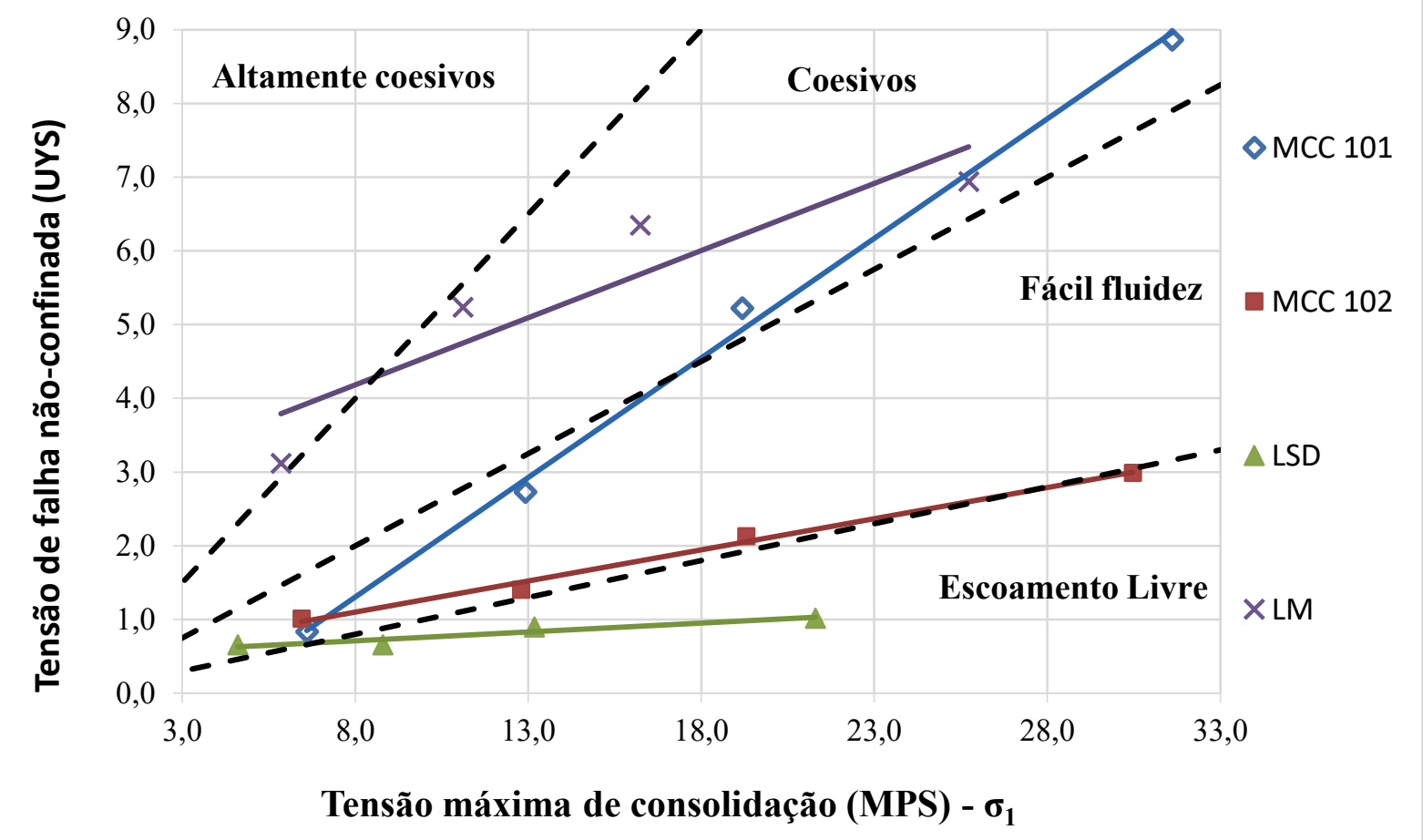

Fonte: Autor, 2018.

Com o auxílio da Figura 36 verifica-se que para maiores tensões de consolidação o fluxo da LSD, LM e da MCC 102 são facilitados enquanto que a MCC 101 tem sua coesão intensificada.

Os resultados do teste de cisalhamento das pré-misturas de excipientes são exemplificados pela mistura base M3 nas Figuras 37 e 38. Os demais resultados são apresentados no Apêndice G. 
Figura 37 - Coesão das pré-misturas que têm como base M3

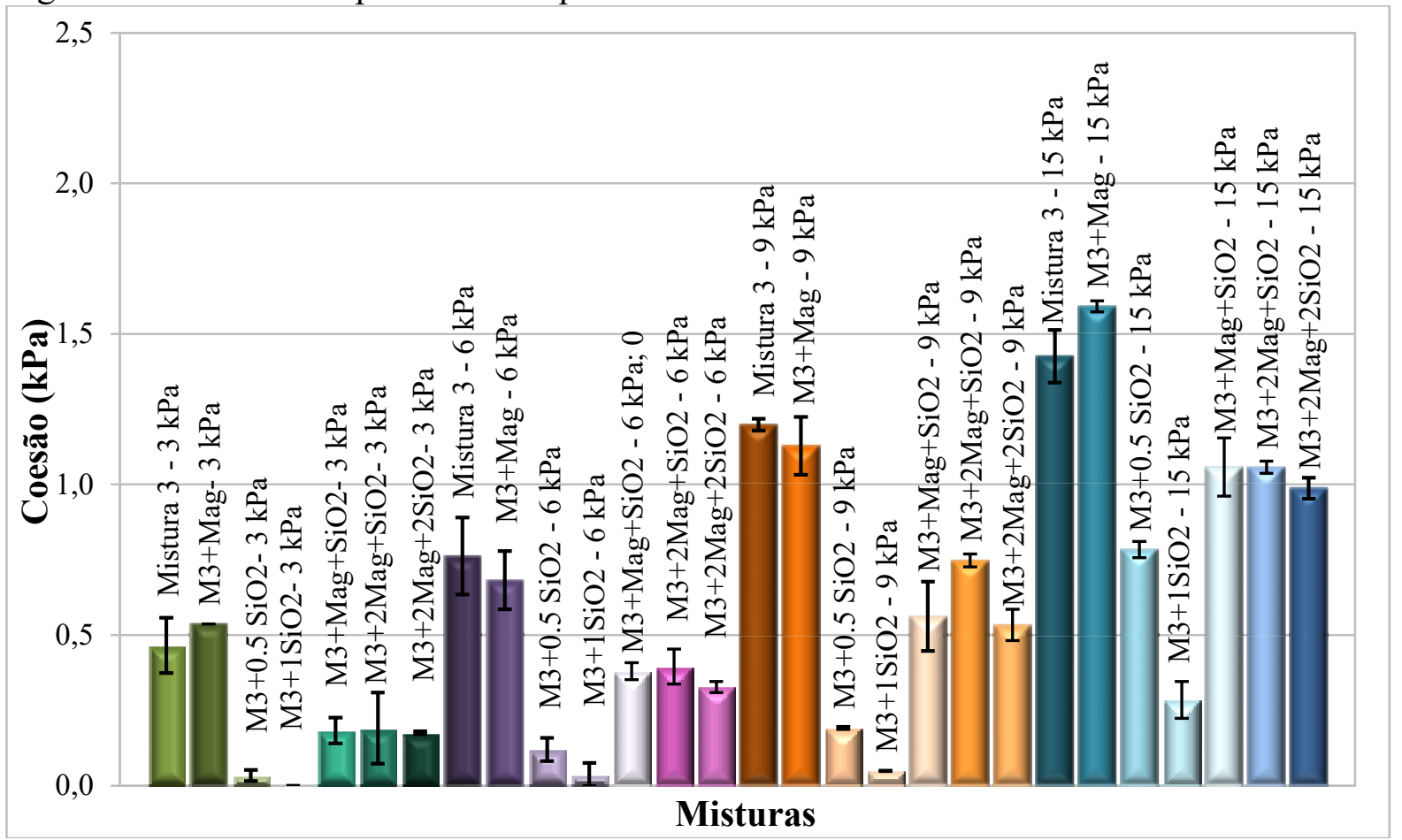

Fonte: Autor, 2018.

O aumento da fração mássica de dióxido de silício causa uma redução mais acentuada da coesão das pré-misturas M3, M1, M4, M6 e M7 independente da tensão de consolidação e para a maioria das tensões de consolidação aplicadas nas pré-misturas M9, M10 e M12. Enquanto que a adição de estearato de magnésio diminuiu levemente a coesão das pré-misturas M9, M10 e M12 independente da tensão de consolidação e para a maioria das tensões de consolidação aplicadas nas pré-misturas M3, M1, M4, M6 e M7.

A adição conjunta de estearato de magnésio e dióxido de silício não apresentam relação com a coesão das pré-misturas frente à consolidação aplicada, como exemplo, as pré-misturas $\mathrm{M} 3+\mathrm{yMag}+\mathrm{zSiO} 2$ possuem mesma coesão à 3 e $15 \mathrm{KPa}$ e nas demais tensões, a maior coesão é da amostra $\mathrm{M} 3+2 \% \mathrm{Mag}+1 \% \mathrm{SiO} 2$ e a menor, a da amostra $\mathrm{M} 3+2 \% \mathrm{Mag}+2 \% \mathrm{SiO} 2 . \operatorname{Logo}$ uma determinada mistura base tem uma coesividade singular referente a uma determinada tensão e adição de excipiente. 
Figura 38 - Função de fluxo das pré-misturas que têm como base M3

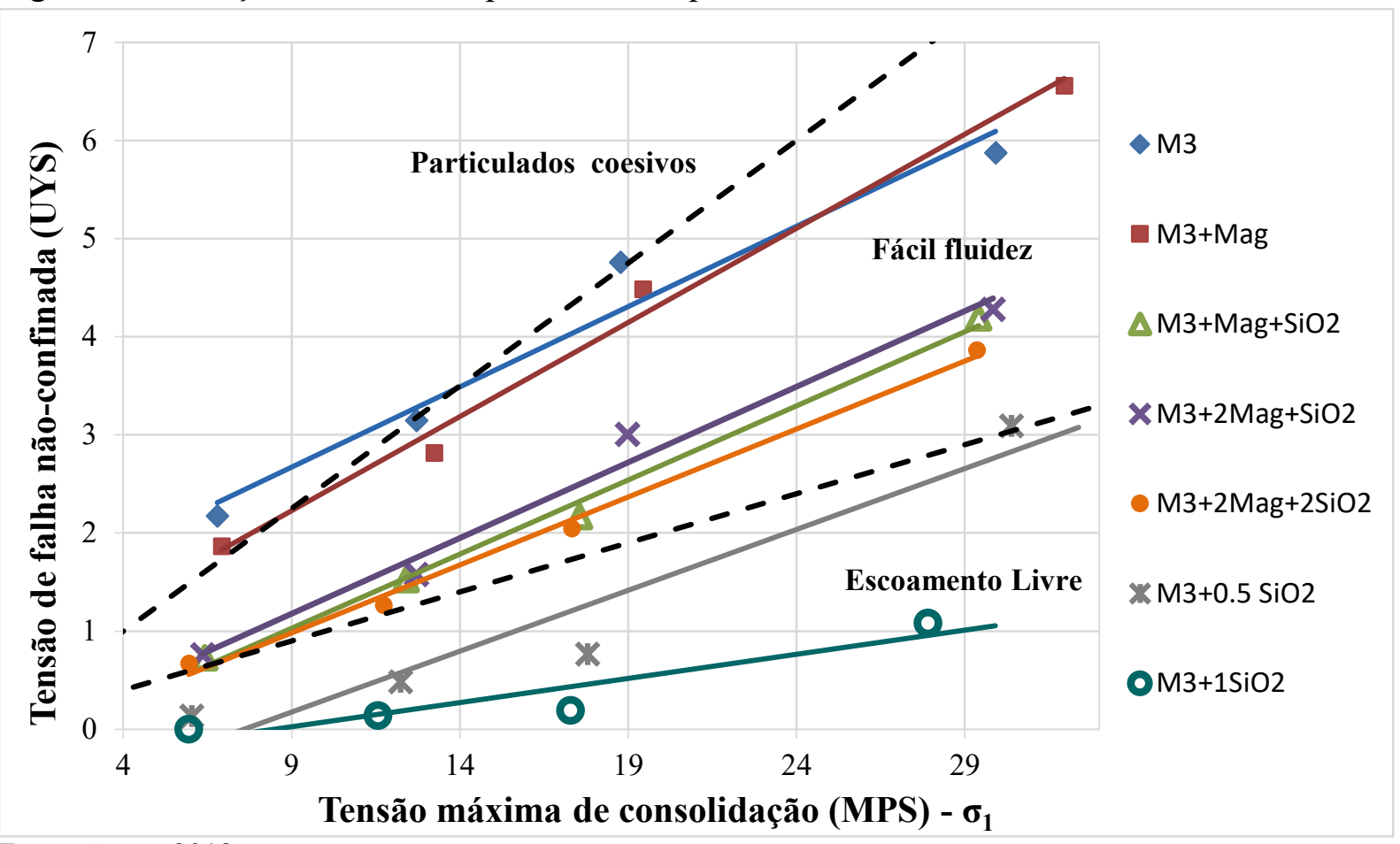

Fonte: Autor, 2018.

As pré-misturas $\mathrm{M} 3+0,5 \% \mathrm{SiO}_{2}, \mathrm{M} 3+1 \% \mathrm{Mag}+1 \mathrm{SiO} 2, \mathrm{M} 3+2 \% \mathrm{Mag}+1 \% \mathrm{SiO} 2 \mathrm{e}$ $\mathrm{M} 3+2 \% \mathrm{Mag}+2 \mathrm{SiO}_{2}$ têm fluxo piorado com o aumento da tensão de consolidação aplicada e enquanto que as demais pré-misturas desse grupo, têm fluxo facilitado. Com isso, o teste de cisalhamento quantifica as constatações anteriores nas quais o dióxido de silício à $1 \%$ em massa demonstra ser o melhor excipiente facilitador de fluxo, uma vez que facilita o fluxo das prémisturas base $\mathrm{M}$ dando origem às pré-misturas $\mathrm{Mx}+1 \% \mathrm{SiO} 2$ cujos escoamentos são classificados como livre.

Por fim, o teste de cisalhamento além de comprovar suposições dos testes anteriores a respeito das misturas de maior e menor coesividade, ele fornece o valor numérico da coesão que pode ser utilizada no dimensionamento do alimentador das máquinas de compressão e a fim de facilitar o processo de transporte das pré-misturas em calhas e em silos além de evitar fenômenos de entupimento nos funis das compressoras. 


\subsection{RESULTADOS PARA AMOSTRAS CONTENDO O PRINCÍPIO ATIVO EFAVIRENZ}

Nesse item serão apresentados os resultados das análises realizadas com as amostras que contêm o princípio ativo Efavirenz em suas formulações.

\subsubsection{Análise de Área superficial: Fissorção de $\mathbf{N}_{2}$}

$\mathrm{Na}$ Tabela 25 estão os valores médios da área superficial das pré-misturas contendo Efavirenz e suas respectivas relações de composição, os valores de cada análise individual constam no Apêndice H.

Tabela 25 - Área superficial e composição das amostras com Efavirenz.

\begin{tabular}{|c|c|c|c|c|c|c|}
\hline Amostra & Análise & $\begin{array}{c}\text { Área superficial } \\
\left(\mathrm{m}^{2} / \mathrm{g}\right)\end{array}$ & $\begin{array}{c}\text { Lactose } \\
(\mathrm{g})\end{array}$ & $\begin{array}{c}\mathrm{SiO}_{2} \\
(\mathrm{~g})\end{array}$ & $\begin{array}{c}\text { CMNa } \\
(\mathrm{g})\end{array}$ & $\begin{array}{c}\text { Manitol } \\
(\mathrm{g})\end{array}$ \\
\hline \multirow{2}{*}{$\begin{array}{c}\text { MCOLEFV } \\
0414 \\
\end{array}$} & Média & 1,77 & \multirow{2}{*}{$4 x$} & \multirow{2}{*}{$\mathrm{x} / 7$} & \multirow{2}{*}{ - } & \multirow{2}{*}{ - } \\
\hline & DP & 0,17 & & & & \\
\hline \multirow{2}{*}{$\begin{array}{c}\text { MCOLEFV } \\
0514\end{array}$} & Média & 2,66 & \multirow{2}{*}{$2 \mathrm{x}$} & \multirow{2}{*}{$\mathrm{x} / 14$} & \multirow{2}{*}{$\mathrm{x} / 12$} & \multirow{2}{*}{ - } \\
\hline & DP & 0,00 & & & & \\
\hline \multirow{2}{*}{$\begin{array}{c}\text { MCOLEFV } \\
0715\end{array}$} & Média & 2,63 & \multirow{2}{*}{$2 x$} & \multirow{2}{*}{$\mathrm{x} / 14$} & \multirow{2}{*}{$\mathrm{x} / 5$} & \multirow{2}{*}{-} \\
\hline & DP & 0,26 & & & & \\
\hline \multirow{2}{*}{$\begin{array}{c}\text { MCOLEFV } \\
0115\end{array}$} & Média & 2,81 & \multirow{2}{*}{$\mathrm{x}$} & \multirow{2}{*}{$\mathrm{x} / 14$} & \multirow{2}{*}{$\mathrm{x} / 5$} & \multirow{2}{*}{-} \\
\hline & DP & 0,05 & & & & \\
\hline \multirow{2}{*}{$\begin{array}{c}\text { MCOLEFV } \\
0614\end{array}$} & Média & 2,95 & \multirow{2}{*}{$\mathrm{x}$} & \multirow{2}{*}{$\mathrm{x} / 14$} & \multirow{2}{*}{$\mathrm{x} / 5$} & \multirow{2}{*}{$\mathrm{X}$} \\
\hline & DP & 0,23 & & & & \\
\hline
\end{tabular}

Fonte: Autor, 2018.

Avaliando-se a Tabela 25 e as composições das pré-misturas MCOLEFV 0514 e 0715 observa-se que a adição de croscamelose sódica não altera a área superficial. Comparando-se MCOLEFV 0614 com MCOLEFV 0715, observa-se há a substituição de uma porcentagem mássica de lactose da mistura MCOLEFV 0715 por manitol, originando MCOLEFV 0614. Em vista disso, o manitol eleva a área superficial. Entretanto, considerando os desvios padrões das medidas, as amostras apresentaram áreas superficiais próximas de $2,7 \mathrm{~m}^{2} / \mathrm{g}$, exceto a amostra MCOLEFV 0414.

Em linhas gerais, uma maior área superficial favorece uma maior adsorção de água (umidade) pela formulação, podendo prejudicar a fluidez do material. Esse fenômeno pode destacar a pré-mistura MCOLEFV 0414 dentre as demais, caso essa propriedade justifique seu comportamento nos testes seguintes. 


\subsubsection{Análise granulométrica}

Os diâmetros médios volumétricos são apresentados na Tabela 26 e a distribuição granulométrica das pré-misturas contendo Efavirenz são ilustradas na Figura 39.

Tabela 26 - Diâmetro médio volumétrico das amostras que contêm o princípio ativo e do Efavirenz

Fonte: Autor, 2018.

\begin{tabular}{c|c}
\hline Mistura & $\mathbf{d v}(\boldsymbol{\mu m})$ \\
\hline Efavirenz & 45,51 \\
\hline MCOLEFV 0414 & 110,40 \\
\hline MCOLEFV 0514 & 53,42 \\
\hline MCOLEFV 0715 & 67,38 \\
\hline MCOLEFV 0115 & 60,50 \\
\hline MCOLEFV 0614 & 64,16 \\
\hline
\end{tabular}

Figura 39 - Distribuição granulométrica das amostras que contêm o princípio ativo e do Efavirenz

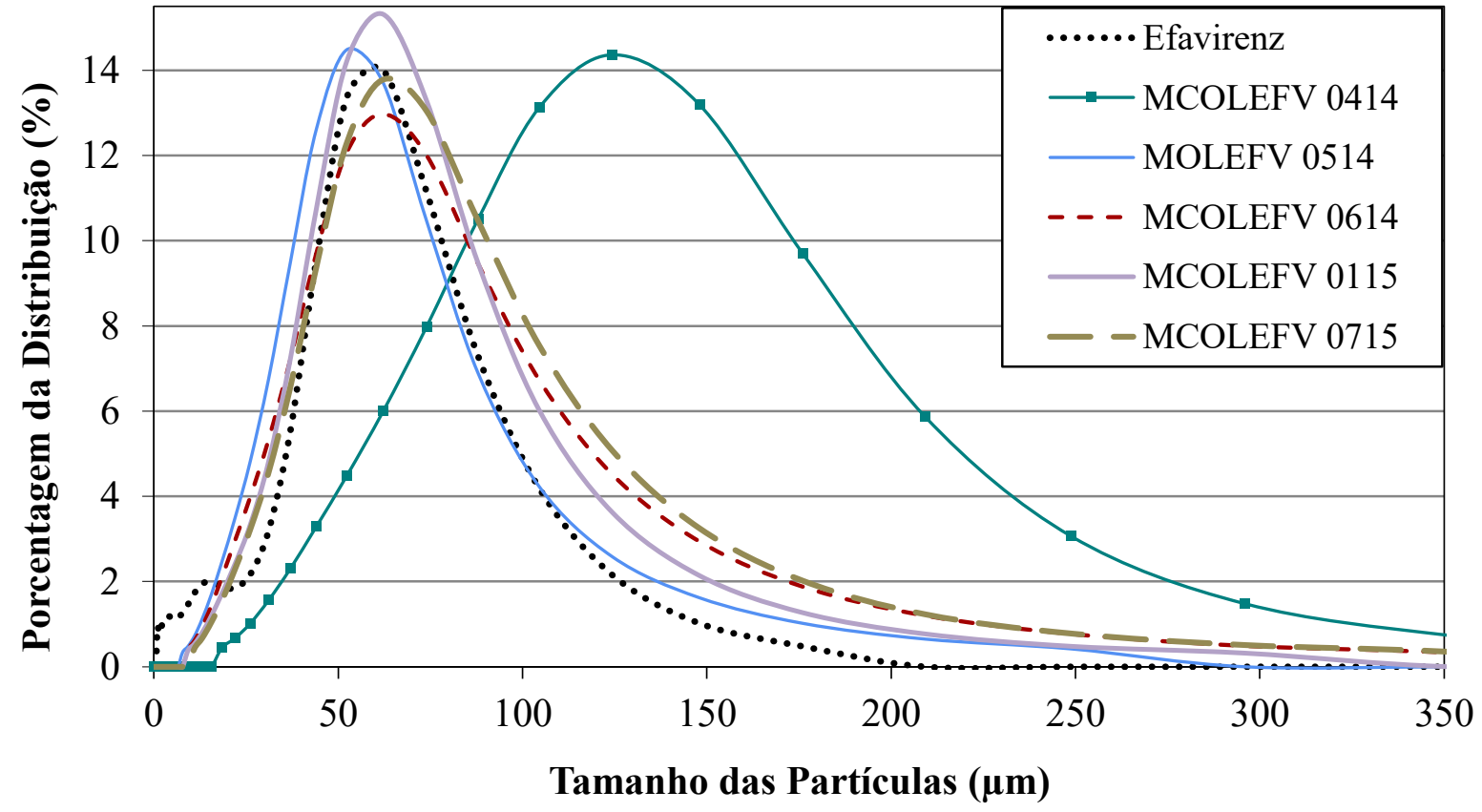

Fonte: Autor, 2018.

Considerando o gráfico da Figura 39, apenas o Efavirenz apresenta comportamento polidisperso, as demais amostras, monodisperso. O Efavirenz apresenta o menor diâmetro médio e a mistura MCOLEFV 0414, o maior. Este fato explica a menor área superficial observada para este material; desta forma a diferença na área superficial é consequência da granulometria e não outra propriedade estrutural (poros) ou superficial da amostra. 
Constata-se ainda que o aumento do teor de croscamelose sódica na composição da amostra acarretou em um aumento da granulometria do produto, conforme observado na comparação das pré-misturas MCOLEFV 0514 e 0715. Já a substituição de parte da Lactose por Manitol praticamente não afeta a granulometria nem a área superficial do produto.

Segundo as análises de área superficial e granulometria, as pré-misturas MCOLEFV 0715, 0115 e 0614 apresentam características semelhantes e reprodutíveis independente da composição, sendo portanto, as amostras preferenciais.

\subsubsection{Massa específica}

Os resultados da massa específica das pré-misturas que contêm Efavirenz são apresentados na Tabela 27. Os valores de cada análise individual constam no Apêndice H.

Tabela 27 - Massa específica das amostras que contêm o princípio ativo Efavirenz

\begin{tabular}{c|c|c|c|c|c}
\hline \multirow{2}{*}{ Amostra } & \multirow{2}{*}{ Análise } & \multicolumn{3}{|c|}{ CDB $(\mathbf{g} / \mathbf{m L})$} & \multirow{2}{*}{ Preal $(\mathbf{g} / \mathbf{m L})$} \\
\cline { 3 - 6 } & & $\mathbf{E F}$. & Comp. & Perm. & \\
\hline MCOLEFV & Média & 0,6284 & 0,6140 & 0,6205 & 1,5233 \\
0414 & DP & 0,0141 & 0,0042 & 0,0021 & 0,0015 \\
\hline MCOLEFV & Média & 0,4664 & 0,5000 & 0,4940 & 1,5173 \\
0514 & DP & 0,0017 & 0,0141 & 0,0255 & 0,0026 \\
\hline MCOLEFV & Média & 0,4708 & 0,4820 & 0,4715 & 1,4813 \\
0715 & DP & 0,0017 & 0,0085 & 0,0163 & 0,0017 \\
\hline MCOLEFV & Média & 0,4826 & 0,4855 & 0,4900 & - \\
0115 & DP & 0,0025 & 0,0064 & 0,0014 & - \\
\hline MCOLEFV & Média & 0,4482 & 0,4490 & 0,4495 & 1,4884 \\
\cline { 3 - 5 } 0614 & DP & 0,0059 & 0,0057 & 0,0502 & 0,0013 \\
\hline
\end{tabular}

Fonte: Autor, 2018.

Constata-se na Tabela 27 que a amostra de maiores massas específica aparente e real é a MCOLEFV 0414. Dentre as amostras, a MCOLEFV 0514 foi a mais suscetível as condições do processo, apresentado variações importantes no valor da massa espefícica aparente em cada teste: Energia de Fluxo (EF), Compressibilidade (Comp) e Permeabilidade (Perm.).

As três últimas amostras destacam-se novamente como as mais propensas para aplicação industrial, pois praticamente não variaram sua massa específica em função do teste realizado. Sendo que, dentre elas, a amostra contendo Manitol (MCOLEFV 0614) apresenta a menor massa específica aparente, indicando uma tendência coesiva em formar aglomerados internamente vazios que apesar de não serem desfeitos pelas condições dos testes realizados, 
justifica o maior volume ocupado pelas partículas constituintes e consequentemente, menor massa específica.

\subsubsection{Testes de Estabilidade e de Fluxo variável}

Os resultados do teste de estabilidade e fluxo variável são apresentados na Tabela 28 e na forma de gráfico na Figura 40. Os demais resultados são apresentados no Apêndice H.

Tabela 28 - Teste de Estabilidade e Fluxo Variável

\begin{tabular}{c|c|c|c|c}
\hline \multicolumn{1}{c|}{ Amostra } & Análise & $\begin{array}{c}\text { BFE } \\
(\mathbf{m J})\end{array}$ & SI & FRI \\
\hline \multirow{2}{*}{ MCOLEFV 0414 } & Média & 490,19 & 1,06 & 1,38 \\
\cline { 2 - 5 } & DP & 2,44 & 0,08 & 0,05 \\
\hline \multirow{2}{*}{ MCOLEFV 0514 } & Média & 485,10 & 0,54 & 1,22 \\
\cline { 2 - 5 } & DP & 17,89 & 0,07 & 0,01 \\
\hline \multirow{2}{*}{ MCOLEFV 0715 } & Média & 498,53 & 0,76 & 1,22 \\
\hline \multirow{2}{*}{ MCOLEFV 0115 } & DP & 4,41 & 0,01 & 0,06 \\
\hline \multirow{2}{*}{ MCOLEFV 0614 } & DP & 489,49 & 0,92 & 1,30 \\
& Média & 378,30 & 0,05 & 0,03 \\
\hline
\end{tabular}

Fonte: Autor, 2018.

Conforme o observado na Tabela 28, a substituição de lactose por manitol diminui o BFE da amostra MCOLEFV 0614 quando comparada com MCOLEFV 0715. Verifica-se que a pré-mistura de menor massa específica, MCOLEFV 0614, é também a pré-mistura de menor BFE. Com isso, mais uma vez observa-se a tendência dessa amostra em formar aglomerados internamente vazios. E assim como o verificado no teste das pré-misturas de excipientes farmacêuticos (primeira etapa do trabalho), o menor valor de BFE indica que o volume de pó deslocado pela lâmina apresenta menor massa e requer menor energia para se movimentar.

O aumento de croscamelose sódica manteve os demais índices e melhorou o SI da amostra MCOLEFV 0715. Um fato interessante em relação ao SI da amostra MCOLEFV 0414 é que a quantidade de lactose e dióxido de silício em sua composição têm efeito semelhante à quantidade de manitol presente na amostra MCOLEFV 0614. 
Figura 40 - Perfil de Estabilidade e Fluxo variável das amostras com Efavirenz

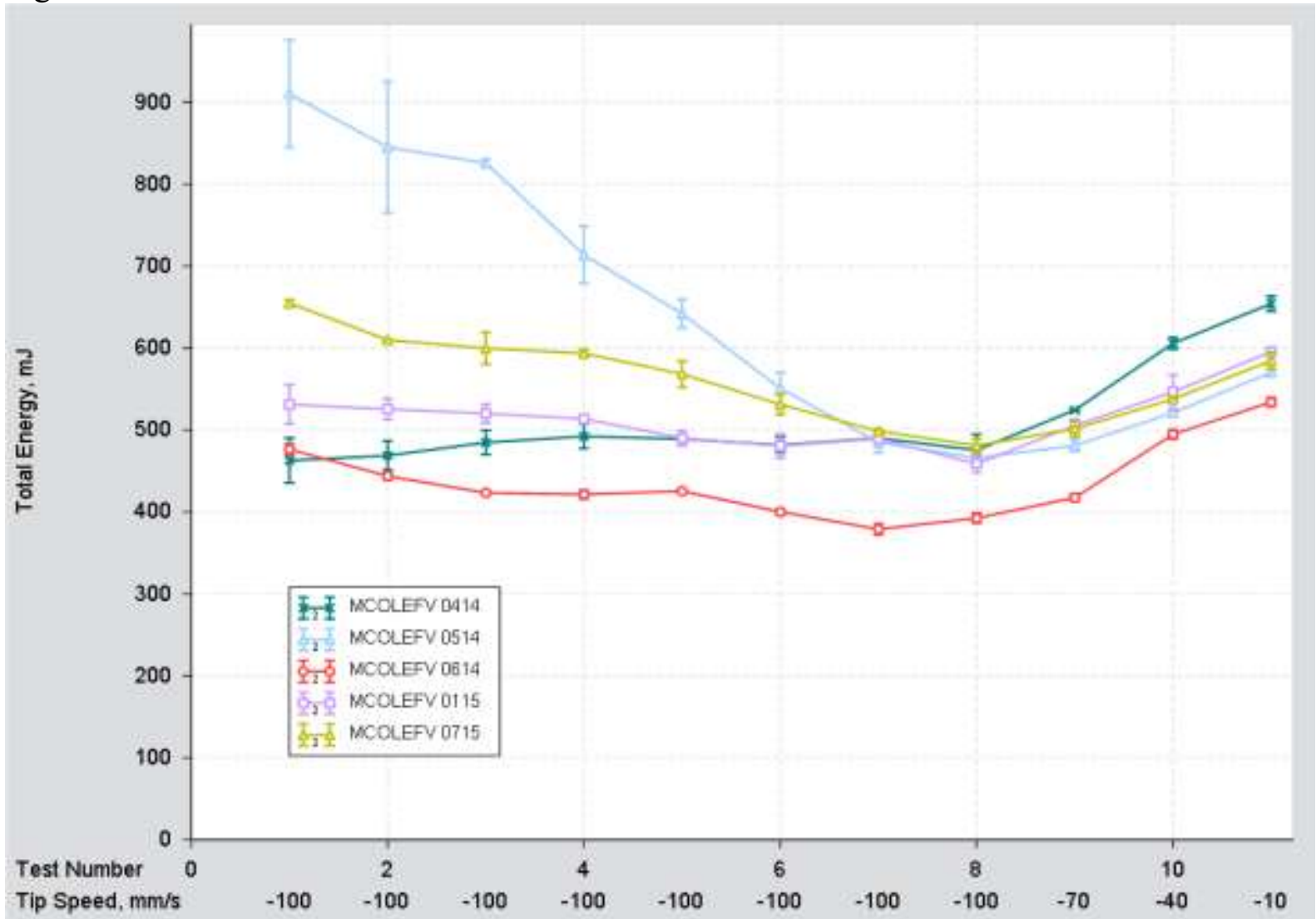

Fonte: Autor, 2018.

A partir do perfil de comportamento no teste de estabilidade da Figura 40, constata-se que, salvo as amostras MCOLEFV 0414 e 0614, as amostras são instáveis. O índice de estabilidade (SI) da amostra MCOLEFV 0414 comprova numericamente sua robustez por ser aproximadamente 1 (um), 1,06.

O teste de fluxo variável demonstra que as amostras são sensíveis à velocidade de escoamento, uma vez grandes incrementos de energia foram necessários para movimentar as amostras em velocidades reduzidas, acarretando em FRI superiores a 1 (um). Isto ocorre devido às interações interparticulares que se pronunciam mais intensamente em baixas velocidades nas quais o contato entre as partículas ocorre por mais tempo.

Por fim, considerando a menor resistência do leito da amostra MCOLEFV 0614, o manitol é o excipiente mais adequado na formulação de pré-misturas contendo Efavirenz visando o menor consumo energético em um processo de movimentação (rosca, agitadores, misturadores, dentre outros). 


\subsubsection{Compressibilidade}

Os resultados do teste de compressibilidade das pré-misturas que contêm Efavirenz são apresentados na Tabela 29 e na Figura 41.

Tabela 29 - Resultados do teste de compressibilidade para pré-misturas contendo Efavirenz

\begin{tabular}{c|c|c}
\hline \multirow{2}{*}{ Amostra } & Análise & $\begin{array}{c}\text { Índice de Compressibilidade } \\
(\mathbf{\%} \mathbf{1 5 , 0} \mathbf{~ k P a})\end{array}$ \\
\hline \multirow{2}{*}{ MCOLEFV 0414 } & Média & 4,42 \\
\cline { 2 - 3 } & DP & 0,23 \\
\hline \multirow{2}{*}{ MCOLEFV 0514 } & Média & 5,23 \\
\cline { 2 - 3 } & DP & 0,48 \\
\hline \multirow{2}{*}{ MCOLEFV 0715 } & Média & 5,11 \\
\cline { 2 - 3 } MCOLEFV 0115 & DP & 0,04 \\
\hline \multirow{2}{*}{ MCOLEFV 0614 } & Dédia & 5,70 \\
& Dédia & 0,22 \\
\hline
\end{tabular}

Fonte: Autor, 2018.

Figura 41 - Teste de compressibilidade para as pré-misturas contendo Efavirenz.

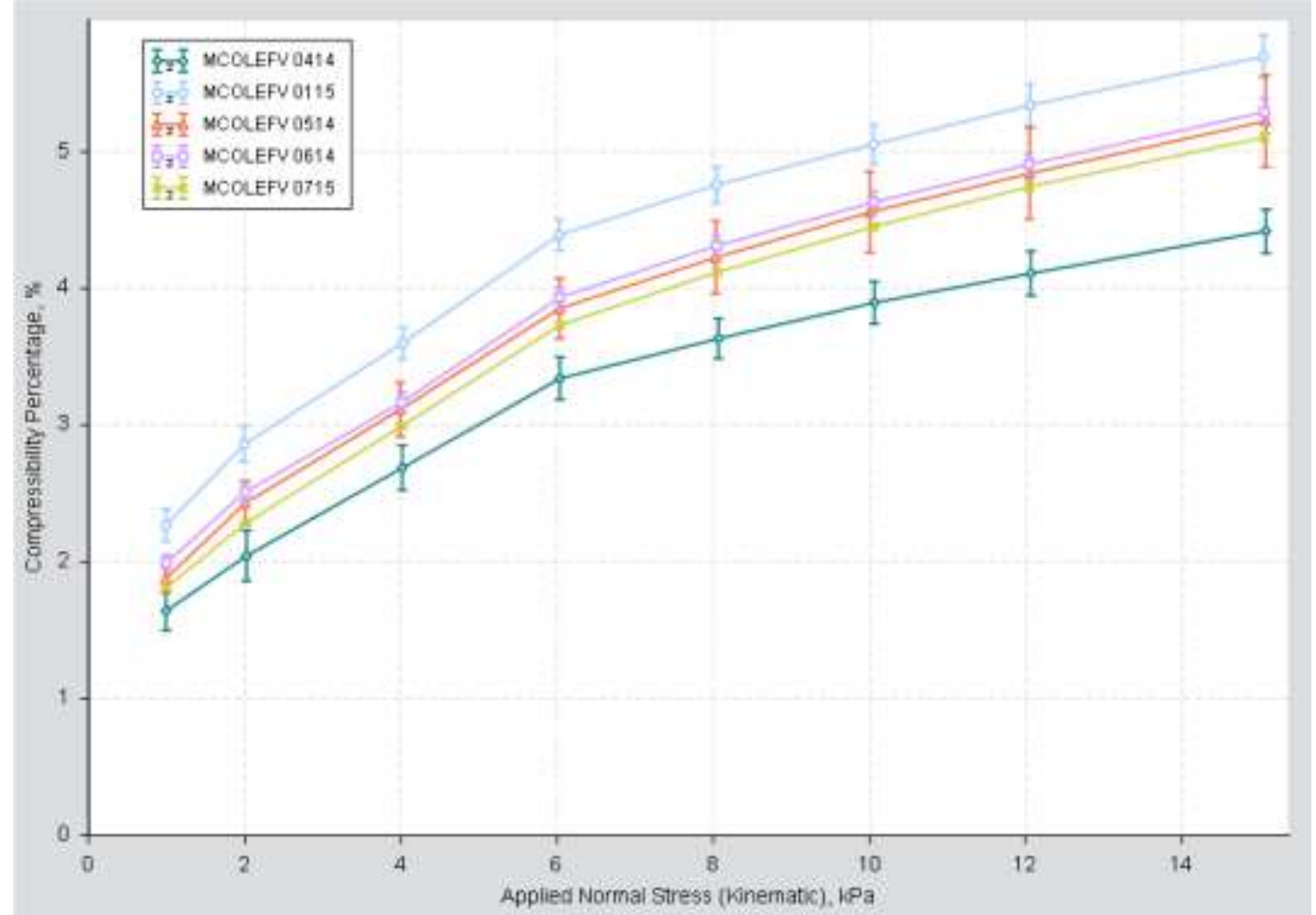

Fonte: Autor, 2018. 
Observa-se na Tabela 29 e na Figura 41 que as pré-misturas têm o mesmo perfil de compressão. A substituição de manitol por lactose não afetou a compressibilidade de MCOLEFV 0614 em comparação com MCOLEFV 0715. Esse fenômeno também é verificado para a adição de croscamelose comparando-se a compressibilidade das pré-misturas MCOLEFV 0514 e 0715.

A amostra MCOLEFV 0414, por sua vez, apresentou menor Índice de compressibilidade, consequentemente, maior massa específica aparente. Com isso menor será a variação das dimensões do comprimido quando submetido à compressão e menores forças de compressão serão necessárias para que haja a formação do comprimido a partir de formulações com MCOLEFV 0414.

\subsubsection{Permeabilidade}

Os resultados do teste de permeabilidade das pré-misturas que contêm Efavirenz são apresentados na Tabela 30 e na Figura 42.

Tabela 30 - Teste de Permeabilidade para as amostras contendo Efavirenz.

\begin{tabular}{c|c|c}
\hline Amostra & Análise & PD $(\mathbf{m B a r}$ à $\mathbf{1 5 , 0} \mathbf{k P a})$ \\
\hline MCOLEFV & Média & 1,02 \\
\cline { 2 - 3 } 0414 & DP & 0,08 \\
\hline MCOLEFV & Média & 0,51 \\
\cline { 2 - 3 } 0514 & DP & 0,17 \\
\hline MCOLEFV & Média & 0,36 \\
\cline { 2 - 3 } 0715 & DP & 0,15 \\
\hline MCOLEFV & Média & 0,96 \\
0115 & DP & 0,15 \\
\hline MCOLEFV & Média & 0,66 \\
0614 & DP & 0,05 \\
\hline
\end{tabular}

Fonte: Autor, 2018. 
Figura 42 - Teste de permeabilidade para pré-misturas contendo Efavirenz.

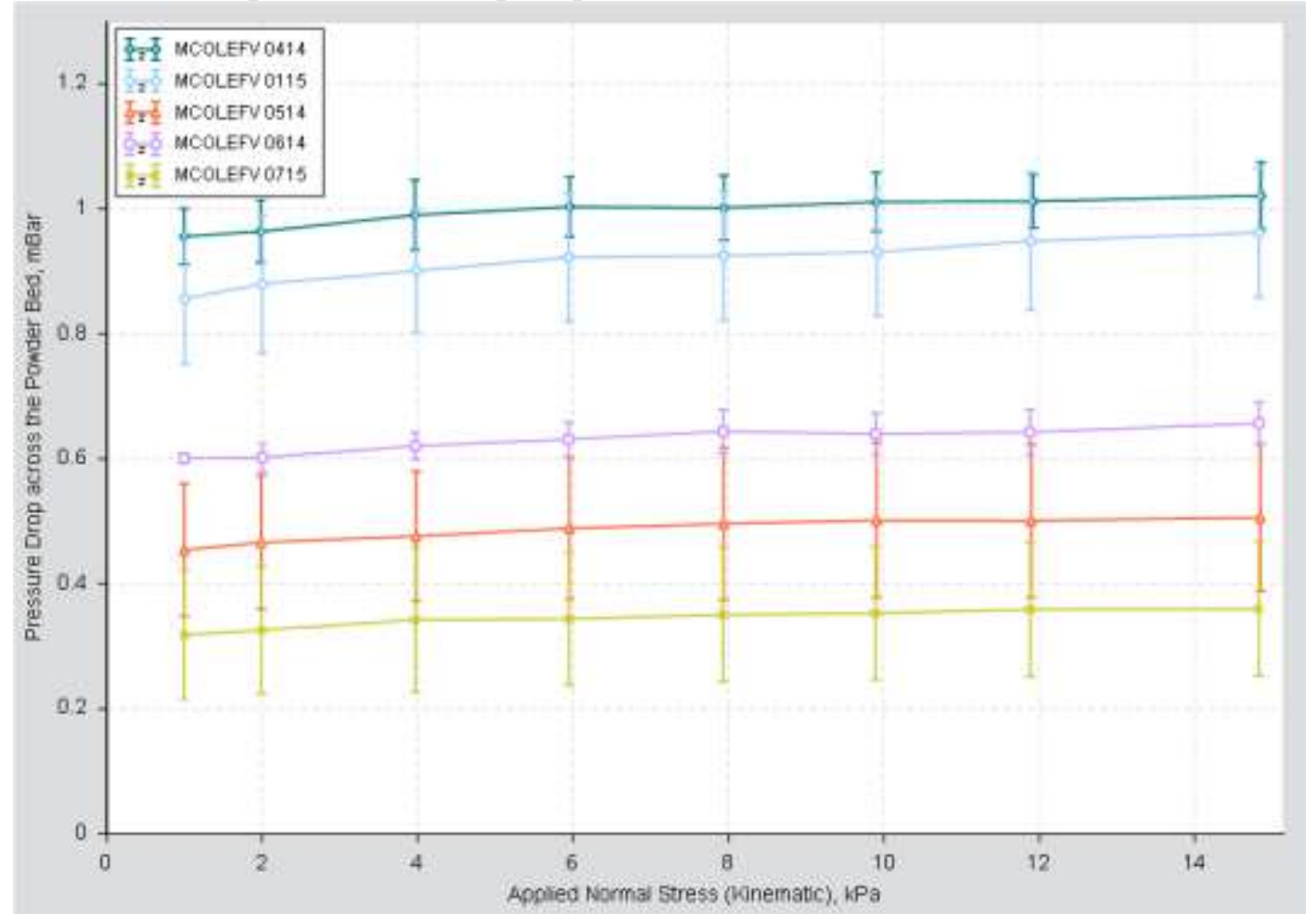

Fonte: Autor, 2018.

Dado os resultados da Tabela 30 e Figura 42 percebe-se a influência da adição de croscamelose em diminuir queda de pressão à $15 \mathrm{kPa}(\mathrm{PD} 15 \mathrm{kPa})$ no leito das amostras MCOLEFV 0715 em relação à MCOLEFV 0514. Sendo assim, esse excipiente previne o efeito capping.

A substituição de lactose por manitol aumenta a queda de pressão de MCOLEFV 0614 comparando-se com MCOLEFV 0715. E em se tratando da pré-mistura contendo manitol, apesar de MCOLEFV 0614 apresentar leito de maior porosidade (menor massa específica aparente e mesma compressibilidade), ela não apresenta a melhor Permeabilidade (menor perda de carga).

Logo, a melhor pré-mistura para desaeração durante o processo de compressão é a MCOLEFV 0715 enquanto que MCOLEFV 0414, por apresentar maior queda de pressão, é a pré-mistura cujo produto final possui a maior propabilidade de sofrer o efeito capping.

\subsubsection{Aeração}

Os resultados do teste de aeração das pré-misturas que contêm Efavirenz são apresentados na Tabela 31 e na Figura 43. 
Tabela 31 - Resultados do teste de aeração para pré-misturas contendo Efavirenz

Fonte: Autor, 2018.

\begin{tabular}{c|c|c|c}
\hline Mistura & Análise & $\mathbf{A E}_{\mathbf{7 ~ m J}}$ & $\mathbf{A R}_{7}$ \\
\hline \multirow{2}{*}{ MCOLEFV 0414 } & Média & 15,32 & 32,33 \\
\cline { 2 - 4 } & DP & 2,02 & 6,59 \\
\hline \multirow{2}{*}{ MCOLEFV 0514 } & Média & 40,10 & 13,78 \\
\cline { 2 - 4 } & DP & 10,03 & 2,40 \\
\hline \multirow{2}{*}{ MCOLEFV 0715 } & Média & 32,83 & 17,48 \\
\cline { 2 - 4 } & DP & 2,88 & 0,03 \\
\hline \multirow{2}{*}{ MCOLEFV 0115 } & Média & 16,76 & 27,68 \\
\cline { 2 - 4 } & DP & 7,61 & 8,17 \\
\hline \multirow{2}{*}{ MCOLEFV 0614 } & Média & 11,64 & 36,73 \\
\cline { 2 - 4 } & DP & 0,60 & 1,64 \\
\hline
\end{tabular}

Analisando-se a Tabela 31, constata-se que a presença de manitol na amostra MCOLEFV 0614 promove o aumento da razão de aeração ( $A_{R}{ }_{7}$ ) e diminuição da energia de aeração $\left(\mathrm{AE}_{7 \mathrm{~mJ}}\right)$ quando esta amostra é comparada com a amostra MCOLEFV 0715. O mesmo efeito ocorre com o acréscimo de croscamelose sódica (MCOLEFV 0715 e MCOLEFV 0514).

As amostras de menores parâmetros são a MCOLEFV 0514 (menor AR) e a MCOLEFV 0614 (menor $\mathrm{AE}_{7}$ ). Porém, visto o comportamento da MCOLEFV 0614 nos testes anteriores, pode-se atribuir a sua menor energia de aeração à formação de aglomerados internamente vazios que, por serem leves, requerem menor energia para que ocorra aeração do leito.

A pré-mistura MCOLEFV 0414, conforme o exposto no teste de aeração das pré-misturas de excipientes, é a amostra de menor tendência coesiva: menor energia de aeração e maior relação de aeração, maior massa específica aparente, menor permeabilidade e menor compressibilidade. A razão de aeração superior à 20 da amostra MCOLEFV 0414 destaca ainda a sua utilização frente as demais amostras em operações como secagem e fluidização cuja a vazão de ar seja de $7 \mathrm{~mm} / \mathrm{s}$. 
Figura 43 - Teste de aeração para amostras contendo Efavirenz



Fonte: Autor, 2018.

Mediante o perfil de aeração das amostras na Figura 43 certifica-se que apesar de não terem atingindo um patamar no qual a energia de aeração tenha sido estabilizada, o estágio de energia alcançado por elas foi próximo de zero sem que houvesse uma redução drástica de energia à baixa vazão de ar. Visto o exposto, são materiais de sensibilidade à aeração mediana e a variação de velocidade do ar adotado, apropriado para a análise.

Os melhores materiais classificados pelo este de aeração são MCOLEFV 0115, 0414 e 0614, já que atingem o patamar zero, características de uma boa fluidização, do tipo particulada, com mínimas interações (coesão) entre as partículas.

\subsubsection{Cisalhamento}

Os resultados do teste de cisalhamento das pré-misturas que contêm Efavirenz são apresentados na Tabela 32 e nas Figuras 44 e 45. 
Figura 44 - Teste de cisalhamento para amostras contendo Efavirenz

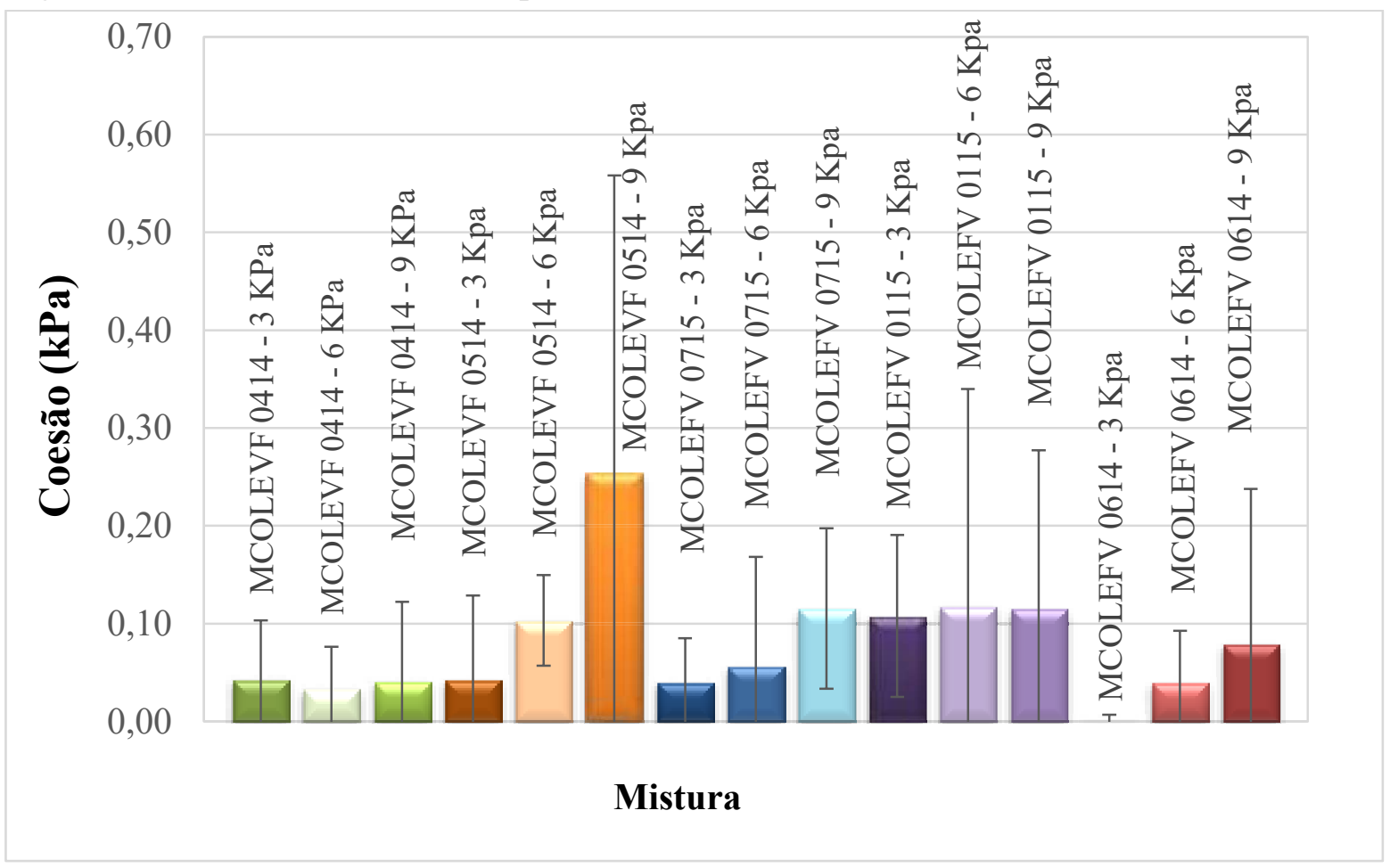

Fonte: Autor, 2018.

Observa-se na Figura 44 que a coesão da pré-mistura MCOLEFV 0414 é baixa e constante para qualquer tensão aplicada. A coesão da MCOLEFV 0514 é crescente e acentuada. As coesões das pré-misturas MCOLEFV 0715 e MCOLEFV 0614 são crescentes e moderadas, sendo a coesão da MCOLEFV 0614 de menor intensidade. Por fim, a coesão da MCOLEFV 0115 é moderada e constante.

Observa-se que o aumento da croscamelose sódica e a substituição de lactose por manitol diminuem a coesão comparando-se as pré-misturas MCOLEFV 0715 com MCOLEFV 0514 e MCOLEFV 0614 com MCOLEFV 0715, respectivamente.

Em vista do exposto, a menor coesão da pré-mistura MCOLEFV 0614 garante melhor fluidez à $3 \mathrm{kPa}$ e também justifica a sua massa específica ser a menor dentre as das demais pré-misturas ao passo que a coesão da pré-mistura MCOLEFV 0414 apesar de ser a segunda menor, é constante para as demais tensões. Esse fenômeno indica que o fluxo dessa pré-mistura é constante, sugerindo que a passagem dessa pré-mistura no funil do alimentador das compressoras e em silos é constante. 
Figura 45 - Função de Fluxo das amostras contendo Efavirenz

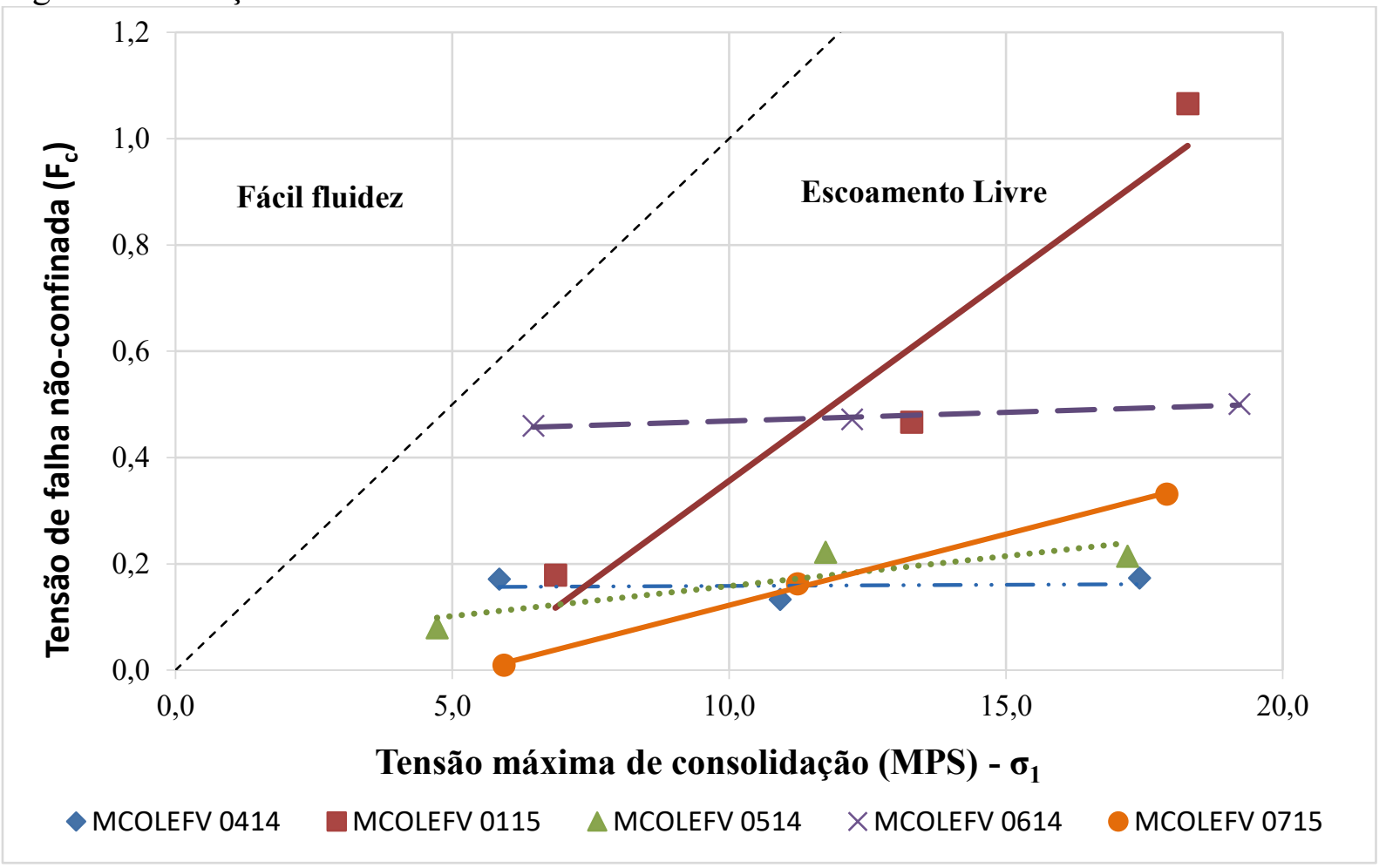

Fonte: Autor, 2018.

Observa-se na Figura 45 que o fluxo de todas as pré-misturas são do tipo escoamento livre quando submetidas à um estado consolidado, porém quando se aproximam de um estado não consolidado (tensão máxima de consolidação tendendo à zero) apenas as coesões das prémisturas MCOLEFV 0115 e 0715 tendem à zero. Além disso, verifica-se que para maiores tensões de consolidação somente o fluxo da MCOLEFV 0115 e MCOLEFV 0715 não é constante, as demais pré-misturas não apresentam alteração de fluxo.

Essa característica faz com que a MCOLEFV 0715 seja a amostra de melhor permeabilidade, maior razão de aeração e menor BFE ao passo que a MCOLEFV 0115 apresenta maior compressibilidade. Já a MCOLEFV 0614 é a amostra que apresenta o pior fluxo, o que justifica o menor BFE, e energia de aeração observados nos testes anteriores

Verifica-se que os parâmetros obtidos nos testes que avaliam as amostras sob um estado não consolidado (teste de estabilidade e fluxo variável e aeração) não estão necessariamente relacionados com a coesão uma vez que ela é uma propriedade medida sob um estado de consolidação. Assim sendo, a função de fluxo é a propriedade que descreve melhor o comportamento das amostras sob um estado não consolidado ao se estudar o comportamento próximo da origem do gráfico e esta portanto, deve ser a informação a ser relacionada com os demais testes. 


\section{CONCLUSÃO}

Atualmente a indústria farmacêutica apresenta várias dificuldades tais como a obtenção de comprimidos que sofrem os efeitos capping, picking e sticking e dificuldades nos processos de scale up e compressão. Como oportunidade para fortalecer o conhecimento sobre as fragilidades que possam evitar e/ou saber lidar com os problemas e avaliar se a substituição de insumos de funcionalidades semelhantes e características físicas diferentes afetaria o processo de fabricação de comprimidos, esse trabalho apresenta uma investigação do comportamento de pré-misturas formuladas com adjuvantes farmacêuticos baseada nos princípios de materiais particulados.

Na primeira etapa do trabalho foi constatado um comportamento mais coesivo para a LM e menos coesivo para a LSD. A LM apresenta um leito menos resistente perante à percolação e agentes externos como pás e roscas e requer menor consumo energético durante operações unitárias como misturadores e agitadores. Em contrapartida, sua baixa compressibilidade, aeração, permeabilidade e maior área superficial pode dificultar processos como secagem, compressão e controle de qualidade morfológico, resultando em comprimidos irregulares que sofram o efeito capping.

A LSD foi identificada com um material de comportamento oposto ao da LM cujas características se assemelham com as da MCC 102 uma vez que apresentaram resultados de BFE, compressibilidade, permeabilidade e aeração similares ou de valores próximos. $\mathrm{O}$ comportamento da MCC 101, por sua vez foi semelhante ao da LM.

$\mathrm{Na}$ análise das pré-misturas formuladas a partir dos diluentes MCC 101, MCC 102, LM e LSD, o estearato de magnésio e dióxido de silício demostraram ser eficientes melhorando suas propriedades de fluxo. O estearato diminuiu o BFE a compressibilidade e a coesão das pré-misturas. Contudo, o dióxido de silício, por diminuir a compressibilidade e a coesão e melhorar a permeabilidade, a aeração e o fluxo das misturas, aparentou ser um facilitador de fluxo mais eficiente em vista das possíveis melhorias que pode causar nos processos de obtenção do comprimido, fluidização e secagem podendo indicar uma redução na tendência ao efeito capping.

A adição conjunta de estearato de magnésio e dióxido de silício não apresentou relação com as propriedades estáticas e dinâmicas das pré-misturas, ou seja, o aumento dos teores de estearato de magnésio juntamente com dióxido de silício não influenciou as condições de aeração, fluidização e consolidação que as pré-misturas $\mathrm{Mx}+\mathrm{y} \% \mathrm{Mag}+\mathrm{z} \% \mathrm{SiO}_{2}$ foram submetidas. 
$\mathrm{Na}$ avaliação das pré-misturas contendo o princípio ativo Efavirez (segunda etapa do trabalho), conclui-se que para cada condição de análise há uma pré-mistura ideal. Sendo a MCOLEFV 0614 a pré-mistura ideal a ser movimentada por agentes externos como pás e roscas e a MCOLEFV 0414, a melhor pré-mistura a ser transportada por ar e a ser empregada na etapa de compressão uma vez que, por ser a pré-mistura de menor variação volumétrica, sugere que uma menor força de compressão será necessária para a obtenção de um comprimido. A MCOLEFV 0715 é a amostra de melhor permeabilidade, consequentemente a que pode originar um produto final de menor tendência ao efeito capping.

Por fim, apesar dos testes estáticos e na iminência do movimento não serem empregados no controle de qualidade da indústria farmacêutica, tão pouco serem constituintes da Farmacopeia, eles demonstram ser úteis na caracterização dos insumos farmacêuticos puros, pré-misturas e misturas, inclusive as que contêm princípios ativos. 


\section{REFERÊNCIAS}

ABDULLAH, E.C.; GELDART, D. The use of bulk density measurements and flowability indicators. Powder Technology, v.102, p. 151-165, 1999.

ALENCAR, J., R., B.; SOUZA, M., B. Monitoramento da produção de formas farmacêuticas sólidas usando técnica híbrida de modelagem neural e controle estatístico de processo. Revista Brasileira de Ciências Farmacêuticas. v.89, nº 4. São Paulo, 2008. Disponível em: < http://www.rbfarma.org.br/files/pag_279a289_monitoramento.pdfs $>$ Acesso em: out. 2017.

ALLEN, T. Particle size measurement: surface area and pore size determination. vol. 2. 5 ed. Chapman \& Hall, 1997.

B2 BRAZIL. Picnômetro a gás Hélio. Disponível em:

$<$ http://www.b2brazil.com.br/B2brazil/hotsite/ProdDetail.asp?var_cod_assoc=3971\&var_cod _prod_serv=9276> Acesso em: out. de 2017.

BAIÃO, D.B.; CONDOTTA, R., Estudo das Propriedades de Escoamento de Materiais Granulares da Construção Civil. Anais do Congresso Brasileiro de Sistemas Particulados ENEMP 2015. São Carlos. 2015.

BATISTA, C. Estudo teórico e experimental do fluxo de sólidos particulados em silos verticais. Tese de pós-graduação, CAMPINA GRANDE, 2009.

BERNARDES, L. A Granulação de Materiais. GranTec - Tecnologias Para Homogeneização e Granulação de Materiais. São Paulo, 2006.

BROWN, T.; LEMAY, H.; BURSTEN, B. Química: a ciência central. 9a edição. São Paulo: Pearson Prentice Hall, 2008.

CALIL JR, C.; CHEUNG, A. B. Silos: pressões, fluxo, recomendações para o projeto e exemplos de cálculo. São Carlos: USP/EESC/SET, 2007.

CALPA, L.R.S. Estudo preliminar da sinterização de membranas macroporosas de óxido de magnésio. Dissertação de Pós-Graduação, Rio de Janeiro, 2011. Disponível em: < https://www.maxwell.vrac.puc-rio.br/Busca_etds.php?strSecao=especifico\&nrSeq=19423@1 $>$ Acesso em: mai. de 2018.

CAMPOS, M. Análise da escoabilidade de pós. Dissertação de Pós-Graduação, São Carlos, 2012. 
CASTRO, I.,C., R. Desenvolvimento e avaliação de nanocristais de Efavirenz. Relatório de Iniciação Tecnológica (PIBITI), Instituto de Tecnologia em Fármacos

(FARMANGUINHOS) e Fundação Oswaldo Cruz (FIOCRUZ), Rio de Janeiro, 2017.

CERQUEIRA, C. Areia. Associação Nacional das Entidades de Produtores de Agregados para Construção Civil. São Paulo. Disponível em: < http://anepac.org.br/wp/agregados/areia/> Acesso em: out. 2017.

CREMASCO, M. A. Operações Unitárias em sistemas particulados e fluidos mecânicos. São Paulo: Blucher, 2014.

COELHO, M.C. Tecnologia de pós. Notas de aula do Curso de Especialização Pós-Graduada em Farmacotecnia Avançada, Faculdade de Farmácia da Universidade de Lisboa 2007. Disponível em: < http://repositorio.lneg.pt/bitstream/10400.9/810/1/Tecnologia $\% 20 \mathrm{de} \% 20 \mathrm{P} \% \mathrm{C} 3 \% \mathrm{~B} 3 \mathrm{~s} \% 20(2)$. pdf> Acesso em: jul. 2017.

CONDOTTA, R. Coulabilité des poudres cohésives : mesures aux faibles contraintes, granulaires humides et application à une poudre industrielle. Tese de Doutorado, França, 2005. Disponível em: < http://ethesis.inp-toulouse.fr/archive/00000181/> Acesso em: jul. 2018.

COSTA, M., A. et al. Efavirenz Dissolution Enhancement I: Co-Micronization.

Pharmaceutics, Rio de Janeiro, v. 5, p. 1-22, 20 dezembro 2012.

COSTENARO, R.; COLLINS, K.E.; COLLINS, H. Uma análise das determinações de área superficial de nirogênio sobre sílicas e modelagem de interações entre estes compostos. Projeto de Iniciação Científica da Unicamp, Campinas, 2010. Disponível em: < https://www.prp.unicamp.br/pibic/congressos/xviiicongresso/paineis/084589.pdf $>$ Acesso em: mai. 2018.

COSMO QUÍMICA. Estearato de Magnésio Farma. Ficha de informações de segurança de produto químico. FISPQ 100. Revisão 06. 2015. Disponível em: <

http://cosmoquimica2.tempsite.ws/waUpload/0022110201513526.pdf> Acesso em: nov. 2017.

COUTO, A. G.; GONZÁleZ, ORTEGA, G.; PETROVICK, P.R. Granulação. Caderno de Farmácia, v.16, n.1, p. 13, 2000. Disponível em: < https://www.lume.ufrgs.br/bitstream/handle/10183/19356/000294901.pdf> Acesso em: set. 2018.

DFE PHARMA. Croscarmelose sódica. Disponível em: < http://www.dfepharma.com.br/ptpt/excipients/superdisintegrants/primellose.aspx> Acesso em: nov. 2017. 
DIAS, V., H., R. Produção de granulados em leito fluidizado de acordo com uma concepção experimental. Trabalho de Mestrado, Faculdade de Lisboa, 2007. Disponível em: $<$ http://repositorio.ul.pt/bitstream/10451/251/1/3674_Tese_final.pdf> Acesso em: set. 2018.

DIAS, E.; SANTOS, M.; GOTO, M.; OLIVEIRA, M.; SATO, P.; TOMASELLI, B.; RAMOS, A. Mineração, geologia e meio ambiente: Impactos sociais e econômicos da regulamentação conama sobre intervenção em app sobre o setor de agregados e argilas. Relatório Técnico MULTIGEO - RT06011, Fiesp, 2006.

DULLIEN, F.A.L. Porous media fluid transport and pore structure. 2 ed. ACADEMIC PRESS, INC. San Diego, California, 1992.

EVONIK. Dióxido de silício coloidal AEROSIL ${ }^{\circledR}$ para formas farmacêuticas sólidas. Disponível em: $<$ http://www.aerosil.com/product/aerosil/pt/industries/pharmaceuticals/soliddrug-forms/pages/default.aspx $>$ Acessado em: nov. 2017.

FARMACOPEIA BRASILEIRA, $5^{\mathrm{a}}$ ed., parte 1, 2010. Disponível em: $<$ http://www.anvisa.gov.br/hotsite/cd_farmacopeia/pdf/volume1\%2020110216.pdf $>$ Acessado em: jan. 2018.

FARMANGUINHOS. Efavirenz. Resumo Técnico, Fundação Oswaldo Cruz. Disponível em: $<$ http://www2.far.fiocruz.br/farmanguinhos/images/stories/phocadownload/efavirenz\%20rt.pd f> Acessado em: jan. 2018.

FERREIRA, A. O. Excipientes e adjuvantes farmacotécnicos. Revista Brasileira de Ciências Farmacêuticas. v.44, n³. São Paulo, 2008. Disponível em: < https://pt.scribd.com/document/132227867/Curso-Excipientes-Farmacotecnicos> Acessado em: set. 2017.

FERRAZ, G., H. Formas farmacêuticas sólidas: comprimidos e comprimidos revestidos. FCF/USP. São Paulo, 2017. Disponível em: < https://edisciplinas.usp.br/pluginfile.php/3500709/mod_resource/content/0/Comprimidos $\% 20$ e\%20comprimidos\%20revestidos.pdf> Acesso em: out. 2017.

FELICETTI, M. Investigação da influência do tamanho das partículas de materiais pulverulentos sobre a força de adesão em diferentes substratos aplicando a Técnica Centríuga. UFSCAR, SP, 2008.

FITZPATRICK, J.J. et al. Effect of composition and storage conditions on the flowability of dairy powders. International Dairy Journal, v.17, p.383-392, 2007.

FREEMAN, R., COOKE, J. Understanding powder behavior by measuring bulk, flow and shear properties. Pharmaceutical Technology Europe. v. 18, n. 9, 2006. 
FUJIKI A.; AOKI T.; MARUMOTO K.; YOSHIDA M.; TANAKA H. Mixed powder metallurgy process. NISSAN MOTOR. US Pat. 2001037842. Nov. 8, 2001.

HIPOLABOR FARMACÊUTICA. Diferença entre remédios e medicamentos. Disponível em: < http://www.hipolabor.com.br/blog/2014/12/19/hipolabor-explica-qual-diferenca-entreremedios-e-medicamentos/> Acesso em: set. 2017.

INSTITUTION OF CHEMICAL ENGINEERS. Standard shear testing technique for particulate solids using the Jenike shear cell. Rugby,UK: Institution of Chemical Engineers 1989.

JULIANO, P.; BARBOSA-CÁNOVAS, G. V. Food Powders Flowability

Characterization: Theory, Methods, and Applications. Annual Reviews - Food Science and Technology, v. 1, p. 211-239, 2010.

JILIANG, M. XIAOPING, C. DAOYIN, L. Minimum fluidization velocity of particles with wide size distribution at high temperatures. Elsevier, p. 271-278. China, 2012. KOCHEVAR, S. Guia básico para a tecnologia de partículas. 2006. Disponível em: < http://www.pmeasuring.com/wrap/filesApp/basicguide_br/file_1/ver_1271045571/Guiab\%E1 sico_br.pdf $>$ Acesso em: out. 2017.

KONTNY, M.; GRANDOLFI, P.; ZOGRAFI, G. Water vapor sorption of water soluble substances: Studies of crystalline solids below their critical relative humidities.

Pharmaceutical Research. Vol. 4, No. 2, 1987.

LABASTIE, M. Considerações sobre pré-misturas de pós farmacêuticos. Revista Brasileira De Farmácia, 76(3): 82-88, INCQS, Fundação Oswaldo Cruz, 1995.

LEITE, L. Processo de Fabricação de Comprimidos. Relatório de Visita Técnica, Bragança Paulista, 2014.

LUMAY, G. et al. Measuring the flowing properties of powders and grains. Powder Technology, [s.1.], v. 224, p.19-27, jul. 2012. Elsevier BV. Disponível em:

$<$ ttp://dx.doi.org/10.1016/j.powtec.2012.02.015/> Acesso em: out. 2017.

MACHADO, C.S.;. Avaliação do efeito da distribuição granulométrica nas propriedades de escoamento de materiais granulares. Trabalho de Iniciação Científica da FEI, São Paulo, 2014.

MALVERN INSTRUMENTS LTD. Difração à Laser, 2015. Disponível em:

$<$ http://www.malvern.com/br/products/technology/laser-diffraction/> Acesso em: ago. 2017.

MASCARENHAS, F.P.; MESQUITA. A.L.A.; FILHO, S.S.C.; MESQUITA, A.L.A. Identificação de propriedades de fluxo do caulim e dimensionamento de tremonha de 
silo para fluxo mássico. Revista Matéria, v.22, n.4. Pará, 2017. Disponível em: < http://www.scielo.br/pdf/rmat/v22n4/1517-7076-rmat-S1517-7076201700040226.pdf> Acesso em: ago. 2018.

MARQUES, S. Projeto sistema de capitação de pó. Minas Gerais, 2012. Disponível em: < http://pt.slideshare.net/engesv/gerenciamneto-de-projetos-captao-de-p> Acesso em: out. 2017.

MERK. FISPQ da Lactose. 2014. Disponível em: < https://www.google.com.br/url? sa=t\&rct=j\&q=\&esrc=s\&source=web\&cd=4\&cad=rja\&uact= $8 \& v e d=0$ ahUKEwjS77al xarXAhUKEJAKHWn7BI4QFgg3MAM\&url=http $\% 3 \mathrm{~A} \% 2 \mathrm{~F} \% 2 \mathrm{Fw}$ ww.merckmillipore.com\%2FINTERSHOP\%2Fweb\%2FWFS\%2FMerck-ID-

Site\%2Fid ID\%2F-\%2FSGD\%2FShowDocument-File\%3FProductSKU\%3DMDA CHEM108195\%26DocumentId\%3D108195_SDS_BR_Z9.PDF\%26DocumentType\%3DMSD\%26L anguage $\% 3 \mathrm{DZ} \% 26 \mathrm{Country} \% 3 \mathrm{DBR} \% 26 \mathrm{Origin} \% 3 \mathrm{DPDP} \& u s g=\mathrm{AOvVaw} 3 \mathrm{mbj}-$ rSgIInG6J3_zZiVpm> Acesso em: nov. 2017.

MICROMERITICS INSTRUMENT CORPORATION. AccuPyc II 1340 Pycnometer. Disponível em: < http://www.micromeritics.com/Product-Showcase/AccuPyc-II-1340.aspx> Acesso em: mar.2018.

PAPINI, C. Estudo comparativo de métodos de determinação do tamanho de partícula. Tese de Mestrado, São Paulo, 2003. Disponível em: < http://pelicano.ipen.br/PosG30/TextoCompleto/Claudemir\%20Jose\%20Papini_M.pdf> Acesso em: ago. 2017.

PAULA, I., C.; RIBEIRO,J., L., D. Problemas de scaling up no desenvolvimento de produtos farmacêuticos em empresas brasileiras. Produto \& Produção. Vol.5, n. 3, p. 17-32. 2001.

PELEG, M. Flowability of food powders and methods for its evaluation. Journal of Food Process and Engineering, v.1, p.303-328, 1978.

PHARMANOSTRA. Manitol. Informativo técnico. Disponível em: $<$

http://www.gallica.com.br/arquivos/site/materia-prima/manitol.pdf $>$ Acesso em: nov. 2017.

PODCZECK, F.; NEWTON, J.M.; JAMES, M.B. Assessment of adhesion and autoadhesion forces between particles and surfaces. Part II. The investigation of adhesion phenomena of salmeterol xinafoate and lactose monohydrate particles in particle-onparticle and particle-onsurface contact. Jounal of Adhesin. Science. Technology. 9, 475-486. 1995.

RAMOS, G.; MORAES, D. C. M.NG, H. P. Revisão de literatura sobre excipientes Em farmácia de manipulação. Foco. Mogi Guaçu, ano 4, n. 5, 2013

RANG, H. P.; DALE, M. M.; RITTER, J. M. et al. Farmacologia. $7^{\text {a }}$ ed., p.1; Elsevier Editora Ltd. Rio de Janeiro 2012. 
RIBEIRO, I. Análise granulométrica de solos tropicais com granulômetro a laser. Trabalho de Conclusão de Curso de Engenharia Civil, UEG, 2014. Disponível em: < http://www.unucet.ueg.br/biblioteca/arquivos/monografias/ISABELLA_RIBEIRO__TCC_2_FINAL.pdf> Acesso em: ago. 2017.

ROCHA, M., U. Estudo das propriedades reológicas de pré-misturas de excipientes farmacêuticos. Resumo final de Iniciação Científica. Centro Universitário FEI, São Bernardo do Campo, 2017.

RHODES, M. Introduction to particle technology. $2^{\text {a }}$ ed.; John Wiley \& Sons Ltd. 2008.

ROCO, M.C. Particulate Two-Phase Flow. Butterworth-Heinemann, 1002 pp, 1993.

RODRIGUES, E. et al. Terapêutica antiretroviral uma conquista. Departamento de Ações de Saúde - Coordenação Municipal de DST/AIDS CETM. Belém. 2008.

Disponível em: < http://bvsms.saude.gov.br/bvs/publicacoes/terapeutica.pdf > Acesso em: nov. 2017.

SACHET, M., U. Desenvolvimento e caracterização de comprimidos de captopril 25 mg. Trabalho de Conclusão de Curso de Farmácia, UNESQ, Criciúma, 2009. Disponível em: < http://www.bib.unesc.net/biblioteca/sumario/00003E/00003E2D.pdf > Acesso em: nov. 2017.

SAMPAIO, J.; SALVADOR, A. Rochas e minerais industriais. 2ª ed. CETM, 2008.

Disponível em: < http:/www.cetem.gov.br/agrominerais/livros/16-agrominerais-calcariodolomito.pdf $>$ Acesso em: nov. 2017.

SCHULZE, D. Flow Properties of powders and bulk solids (fundamentals). Germany, 2011. Disponível em: < http://www.dietmar-schulze.de/grdle1.pdf> Acesso em: ago. 2017.

SCHWEDES, D. Powders and bulk solids. Behavior, characterization, storage and flow. Springer. Germany, 2007.

SEVILLE, Jonathan; TUZUN, Ugur; CLIFT, Roland. Processing of particulate solids. London: Chapman \& Hall, 1997. 369 p.

SILVA, D. C. Ensaios físicos dos excipientes e avaliação das farmacopeias. Monografia de Pós-Graduação. Instituto de Tecnologia de Fármacos - Farmanguinhos/FIOCRUZ. Rio de Janeiro. 2013.

SMITH, D., J. The Many States of Powder Flow. DJS, Process Consulting Limited, 2016. Disponível em $<$ http://www.djsprocessconsulting.co.uk/The-Many-States-of-Powder-Flow/> Acessado em: ago. 2017. 
SOUZA, M., V., A. Drogas Anti-VHI: Passado, Presente e perspectivas futuras. Quim. Nova. Rio de Janeiro, v.26, n.3, p.366-372.

TANNOUS, K.; ROCHA, S. Dinâmica de Sistemas Sólido-Fluido. APOSTILA DE OPERAÇÕES UNINÁTIAS I Disponível em $<$ http://www.ocw.unicamp.br/fileadmin/user_upload/cursos/EQ651/Capitulo_II.pdf> Acesso em: nov. 2017.

U.S. Pharmacopeia. Disponível em:

<www.pharmacopeia.cn/v29240/usp29nf24s0_c1174.html> Acesso em: jul. 2017.

TOVANI BENZAQUEN INGREDIENETS. Celulose microcristalina e suas aplicações Disponível em $<$

https:/www.google.com.br/url?sa=t\&rct=j\&q=\&esrc=s\&source=web\&cd=7\&cad=rja\&uact $=$ $8 \& v e d=0$ ahUKEwin $1 \mathrm{pK}-$

uLLXAhXKHpAKHTFRBvEQFghKMAY\&url=http $\% 3 \mathrm{~A} \% 2 \mathrm{~F} \% 2 \mathrm{Ffuncionaisnutraceuticos.c}$ om.br\%2Fupload_arquivos\%2F201608\%2F2016080543249001471023501.docx\&usg=AOvV aw036A3WtpLKuqGiSVjFJ8rc> Acesso em: nov. 2017.

TWAIN, MARK. The Big Short. Direção de Adam Mckay. Roteiro: Adam Mckay; Charles Randolph. [s.i]: R, P, P, Diuhde I-company, 2015. P\&B.

U.S. Pharmacopeia. Disponível em:

<www.pharmacopeia.cn/v29240/usp29nf24s0_c1174.html> Acesso em: jul. 2017.

VAN CAMPEN, L.; AMIDON, G.L; ZOGRAFI, G. Moisture sorption kinetics for watersoluble substances. 1. Theoretical considerations of heat transport control. J. Pharm. Sci. 72, 1381-1388, 1983.

VASCONCELOS, P. Transporte pneumático fluidizado estudos de casos aplicados à indústria do alumínio primário. Tese de Doutorado, Universidade Federal do Pará, Belém, 2011. Disponível em: < http://www.proderna.ufpa.br/teses/Paulo\%20Douglas.pdf $>$ Acesso em: nov. 2017.

VIEIRA, V., M., M.; OHAYON, P. Inovação em fármacos e medicamentos: estado-daarte no Brasil e políticas de P\&D. Tese de Doutorado, Fiocruz, 2006. Disponível em: < http://www.far.fiocruz.br/wp-content/uploads/2016/09/Inovacao.pdf> Acesso em: out. 2017.

WOODCOCK, C.R.; MASON, J.S. Bulk Solids Handling: An Introducion to the Practice and Technology. Glasgow: Leonard Hill, 1987. 
APÊNDICE A - Resultados do BET das amostras de excipientes farmacêuticos 


\begin{tabular}{c|c|c}
\hline Amostra & Análise & $\begin{array}{c}\text { Área superficial } \\
\left(\mathbf{m}^{2} / \mathbf{g}\right)\end{array}$ \\
\hline \multirow{4}{*}{ LM } & 1 & 0,28 \\
& 2 & 0,25 \\
& Média & 0,26 \\
& DP & 0,02 \\
\hline \multirow{5}{*}{ LSD } & 1 & 0,11 \\
& 2 & -- \\
& Média & 0,11 \\
\hline \multirow{5}{*}{ MCC 101 } & DP & 0,00 \\
& 1 & 0,71 \\
& 2 & 0,72 \\
& Média & 0,72 \\
& DP & 0,01 \\
\hline \multirow{5}{*}{ MCC 102 } & 1 & 0,64 \\
& 2 & 0,60 \\
& Média & 0,62 \\
\cline { 2 - 3 } & DP & 0,03 \\
\hline
\end{tabular}


APÊNDICE B - Resultados da massa específica aparente condicionada das pré-misturas de excipientes farmacêuticos 


\begin{tabular}{|c|c|c|c|c|c|c|c|c|}
\hline \multirow{3}{*}{ Mistura } & \multirow{3}{*}{ Análise } & \multicolumn{7}{|c|}{ CDB (g/mL) } \\
\hline & & \multirow{2}{*}{$\begin{array}{c}\text { Estabilidad } \\
\text { e e Fluxo } \\
\text { Variável }\end{array}$} & \multirow{2}{*}{$\begin{array}{c}\text { Compres } \\
- \\
\text { sibilidade }\end{array}$} & \multirow{2}{*}{$\begin{array}{c}\text { Perme - } \\
\text { abilidad } \\
\text { e }\end{array}$} & \multicolumn{4}{|c|}{ Cisalhamento } \\
\hline & & & & & $3 \mathrm{kPa}$ & $6 \mathrm{kPa}$ & $9 \mathrm{kPa}$ & $15 \mathrm{kPa}$ \\
\hline \multirow{5}{*}{$\begin{array}{c}\mathrm{MCC} \\
102\end{array}$} & 1 & 0,3612 & 0,3505 & 0,3551 & 0,3828 & 0,3974 & 0,3982 & 0,4471 \\
\hline & 2 & 0,3610 & 0,3516 & 0,3576 & 0,3818 & 0,3939 & 0,3947 & 0,4885 \\
\hline & 3 & 0,3577 & - & - & - & - & - & - \\
\hline & Média & 0,3610 & 0,3511 & 0,3564 & 0,3823 & 0,3956 & 0,3965 & 0,4678 \\
\hline & DP & 0,0020 & 0,0008 & 0,0018 & 0,0007 & 0,0025 & 0,0025 & 0,0293 \\
\hline \multirow{4}{*}{$\begin{array}{c}\text { MCC } \\
101\end{array}$} & 1 & 0,3665 & 0,3702 & 0,3711 & 0,4016 & 0,4152 & 0,4179 & 0,4280 \\
\hline & 2 & 0,3633 & 0,3654 & 0,3644 & 0,4009 & 0,4118 & 0,4185 & 0,4294 \\
\hline & Média & 0,3649 & 0,3678 & 0,3677 & 0,4013 & 0,4135 & 0,4182 & 0,4287 \\
\hline & $\mathrm{DP}$ & 0,0023 & 0,0034 & 0,0047 & 0,0005 & 0,0024 & 0,0004 & 0,0010 \\
\hline \multirow{5}{*}{ LSD } & 1 & 0,6488 & 0,6573 & 0,6586 & 0,6892 & - & - & 0,7304 \\
\hline & 2 & 0,6589 & 0,6542 & 0,6524 & 0,6892 & 0,6931 & 0,7276 & 0,7336 \\
\hline & 3 & 0,6653 & - & - & - & - & - & - \\
\hline & Média & 0,6589 & 0,6558 & 0,6555 & 0,6892 & 0,6931 & 0,7276 & 0,7320 \\
\hline & DP & 0,0083 & 0,0022 & 0,0044 & 0,0000 & 0,0000 & 0,0000 & 0,0023 \\
\hline \multirow{4}{*}{ LM } & 1 & 0,5149 & 0,5471 & 0,5418 & 0,6435 & 0,6909 & 0,7029 & 0,7484 \\
\hline & 2 & 0,5223 & 0,5389 & 0,5431 & 0,6348 & 0,6899 & 0,6960 & 0,7561 \\
\hline & Média & 0,5186 & 0,5430 & 0,5424 & 0,6392 & 0,6904 & 0,6995 & 0,7522 \\
\hline & $\mathrm{DP}$ & 0,0052 & 0,0057 & 0,0009 & 0,0062 & 0,0007 & 0,0049 & 0,0055 \\
\hline
\end{tabular}




\begin{tabular}{|c|c|c|c|c|c|c|c|c|c|}
\hline \multirow{3}{*}{$\begin{array}{c}\text { Excipiente } \\
(\%)\end{array}$} & \multirow{3}{*}{ Análise } & \multicolumn{8}{|c|}{ CDB $(g / m L)_{E F}$} \\
\hline & & \multicolumn{8}{|c|}{ Mistura } \\
\hline & & M1 & M3 & M4 & M6 & M7 & M9 & M10 & M12 \\
\hline \multirow{4}{*}{0} & 1 & 0,4586 & 0,4331 & 0,4734 & 0,4333 & 0,4928 & 0,4451 & 0,4725 & 0,4324 \\
\hline & 2 & 0,4641 & 0,4358 & 0,4750 & 0,4336 & 0,4893 & 0,4435 & 0,4729 & 0,4283 \\
\hline & Média & 0,4613 & 0,4344 & 0,4742 & 0,4334 & 0,4911 & 0,4443 & 0,4727 & 0,4304 \\
\hline & DP & 0,0039 & 0,0019 & 0,0011 & 0,0003 & 0,0025 & 0,0011 & 0,0003 & 0,0029 \\
\hline \multirow{4}{*}{$1 \mathrm{Mag}$} & 1 & 0,4776 & 0,4418 & 0,4826 & 0,4526 & 0,5316 & 0,4730 & 0,5802 & 0,4891 \\
\hline & 2 & 0,5069 & 0,4609 & 0,5116 & 0,4771 & 0,5619 & 0,4944 & 0,5969 & 0,5219 \\
\hline & Média & 0,4923 & 0,4513 & 0,4971 & 0,4648 & 0,5468 & 0,4837 & 0,5885 & 0,5055 \\
\hline & DP & 0,0207 & 0,0135 & 0,0206 & 0,0173 & 0,0214 & 0,0151 & 0,0118 & 0,0232 \\
\hline \multirow{4}{*}{$0,5 \mathrm{SiO} 2$} & 1 & 0,5401 & - & 0,5778 & 0,5199 & 0,5494 & 0,4864 & 0,5471 & 0,5036 \\
\hline & 2 & 0,5576 & - & 0,5859 & 0,5249 & 0,5450 & 0,4881 & 0,5471 & 0,4998 \\
\hline & Média & 0,5488 & - & 0,5819 & 0,5224 & 0,5472 & 0,4873 & 0,5471 & 0,5017 \\
\hline & DP & 0,0123 & - & 0,0057 & 0,0035 & 0,0031 & 0,0012 & 0,0000 & 0,0027 \\
\hline \multirow{4}{*}{$1 \mathrm{SiO} 2$} & 1 & 0,5714 & 0,4973 & - & 0,5322 & - & - & 0,5382 & 0,4937 \\
\hline & 2 & 0,5601 & 0,5050 & - & 0,5264 & - & - & 0,5391 & 0,4968 \\
\hline & Média & 0,5657 & 0,5012 & - & 0,5293 & - & - & 0,5386 & 0,4952 \\
\hline & DP & 0,0080 & 0,0054 & - & 0,0041 & - & - & 0,0006 & 0,0022 \\
\hline \multirow{5}{*}{$\begin{array}{c}1 \mathrm{Mag} \\
+1 \mathrm{SiO} 2\end{array}$} & 1 & 0,5785 & 0,5104 & 0,5820 & 0,5074 & 0,5378 & 0,4942 & 0,5302 & 0,4795 \\
\hline & 2 & 0,5686 & 0,5089 & 0,5711 & 0,5055 & 0,5415 & 0,4941 & 0,5208 & 0,4774 \\
\hline & 3 & - & - & - & - & - & - & 0,6037 & - \\
\hline & Média & 0,5735 & 0,5097 & 0,5766 & 0,5065 & 0,5397 & 0,4941 & 0,5302 & 0,4785 \\
\hline & DP & 0,0070 & 0,0010 & 0,0077 & 0,0014 & 0,0026 & 0,0001 & 0,0454 & 0,0015 \\
\hline \multirow{4}{*}{$\begin{array}{c}2 \mathrm{Mag} \\
+1 \mathrm{SiO} 2\end{array}$} & 1 & 0,5910 & 0,5292 & 0,5988 & 0,5430 & 0,5946 & 0,5453 & 0,5943 & 0,5409 \\
\hline & 2 & 0,5853 & 0,5220 & 0,5779 & 0,5410 & 0,5852 & 0,5304 & 0,5741 & 0,5258 \\
\hline & Média & 0,5881 & 0,5256 & 0,5883 & 0,5390 & 0,5899 & 0,5379 & 0,5842 & 0,5333 \\
\hline & DP & 0,0041 & 0,0051 & 0,0148 & 0,5390 & 0,0067 & 0,0105 & 0,0143 & 0,0107 \\
\hline \multirow{5}{*}{$\begin{array}{c}2 \mathrm{Mag} \\
+2 \% \mathrm{SiO} 2\end{array}$} & 1 & 0,5675 & 0,5073 & 0,5779 & 0,0000 & 0,5652 & 0,5166 & 0,5612 & 0,5044 \\
\hline & 2 & 0,5601 & 0,5051 & 0,5678 & 0,5273 & 0,5571 & 0,5089 & 0,5464 & 0,4947 \\
\hline & 3 & - & - & 0,5621 & 0,5217 & - & - & - & - \\
\hline & Média & $|0,5638|$ & 0,5062 & 0,5678 & 0,5245 & 0,5611 & 0,5127 & 0,5538 & 0,4996 \\
\hline & DP & $0,0052 \mid$ & 0,0016 & 0,0080 & 0,0040 & 0,0057 & 0,0054 & 0,0105 & 0,0069 \\
\hline
\end{tabular}


APÊNDICE C - Resultados do teste de Estabilidade e Fluxo Variável realizado com as pré-misturas de excipientes farmacêuticos 

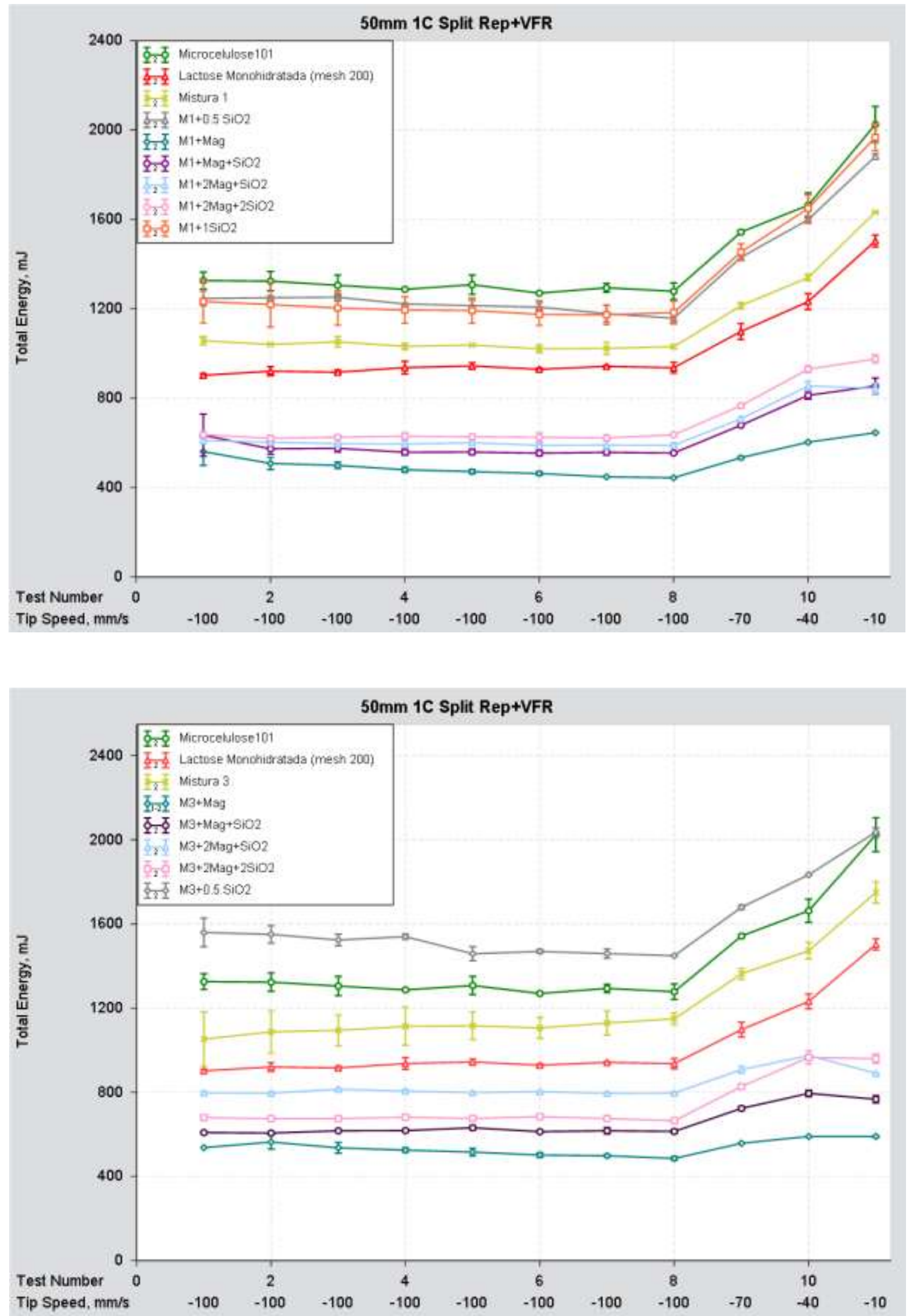

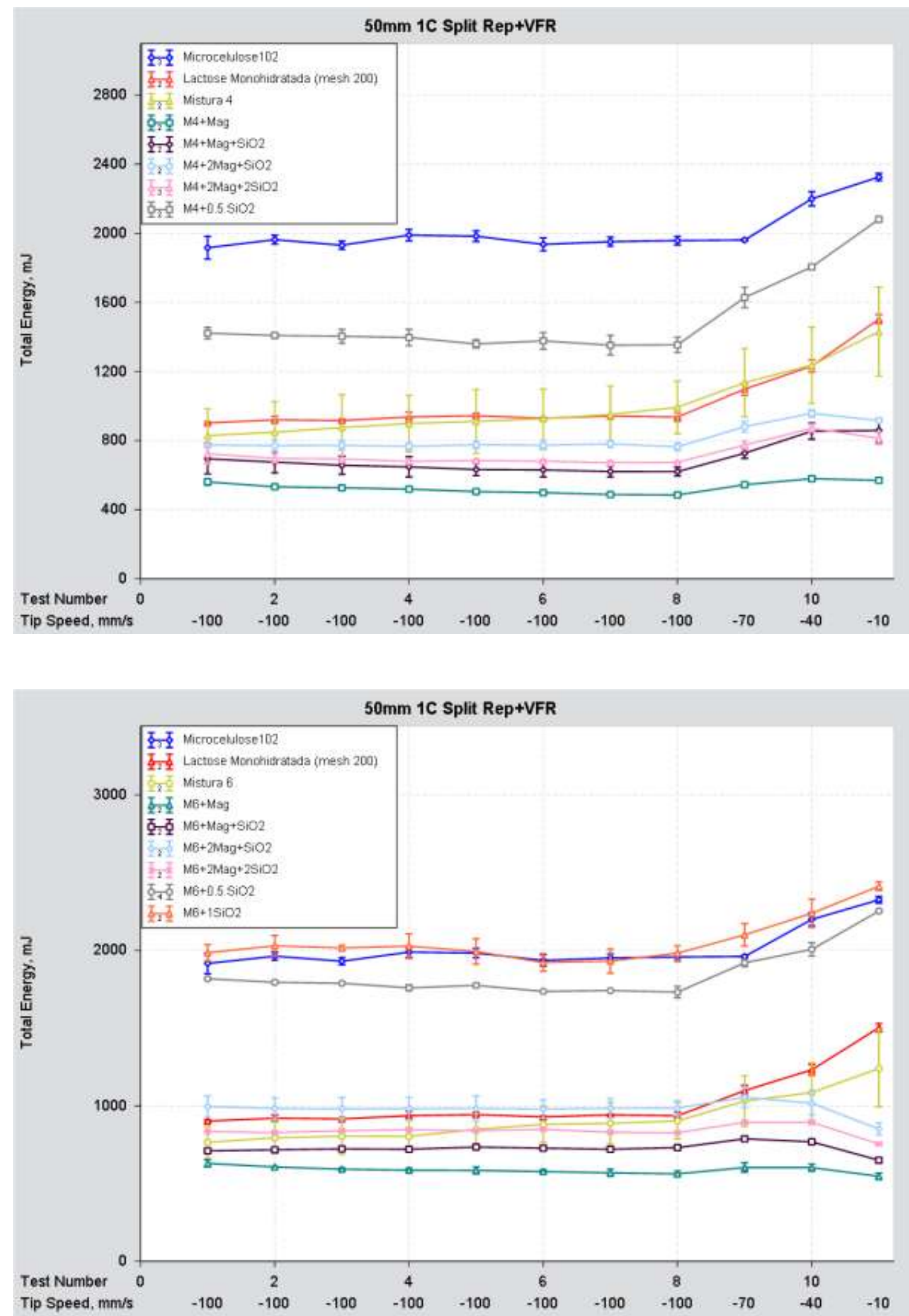

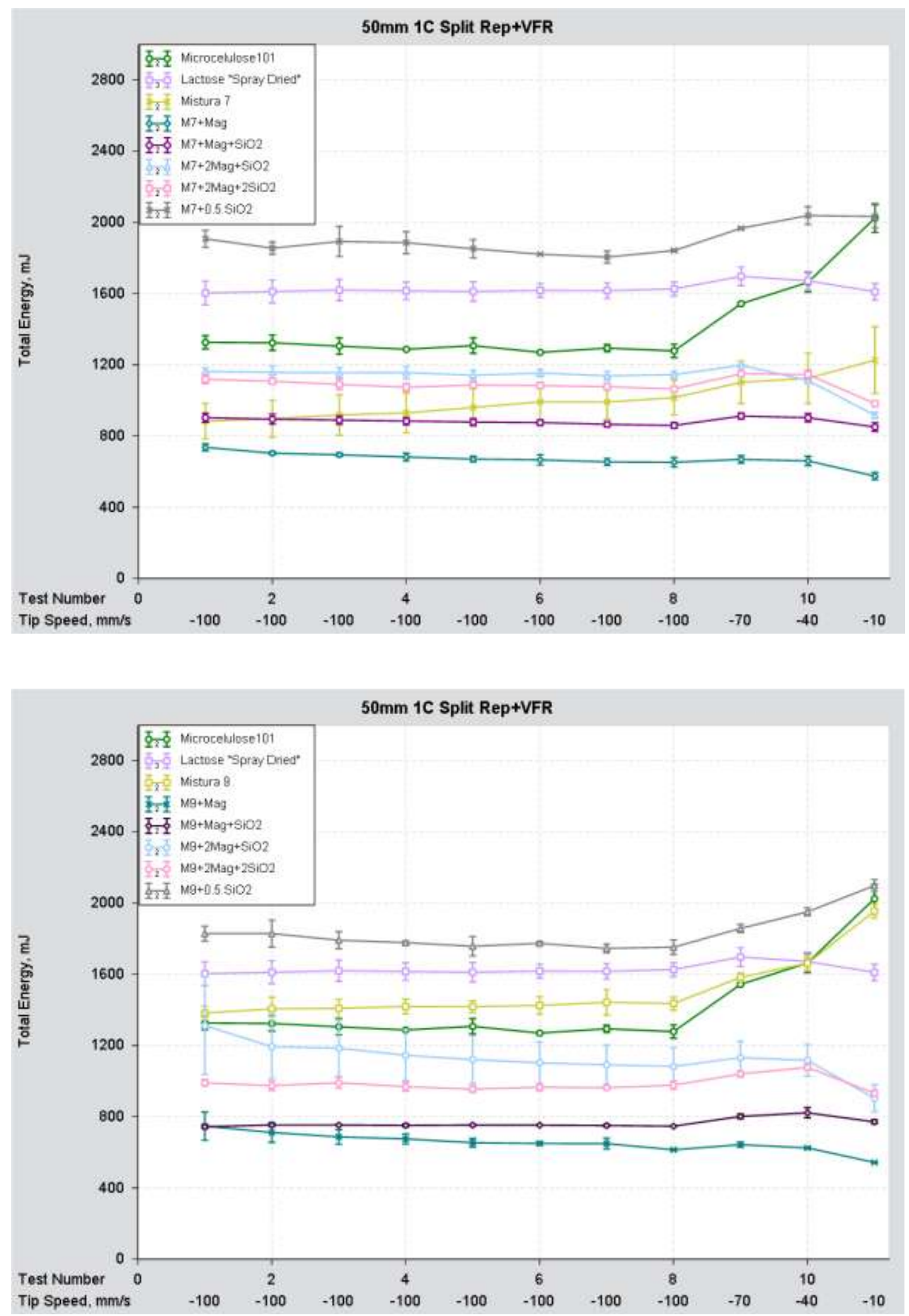

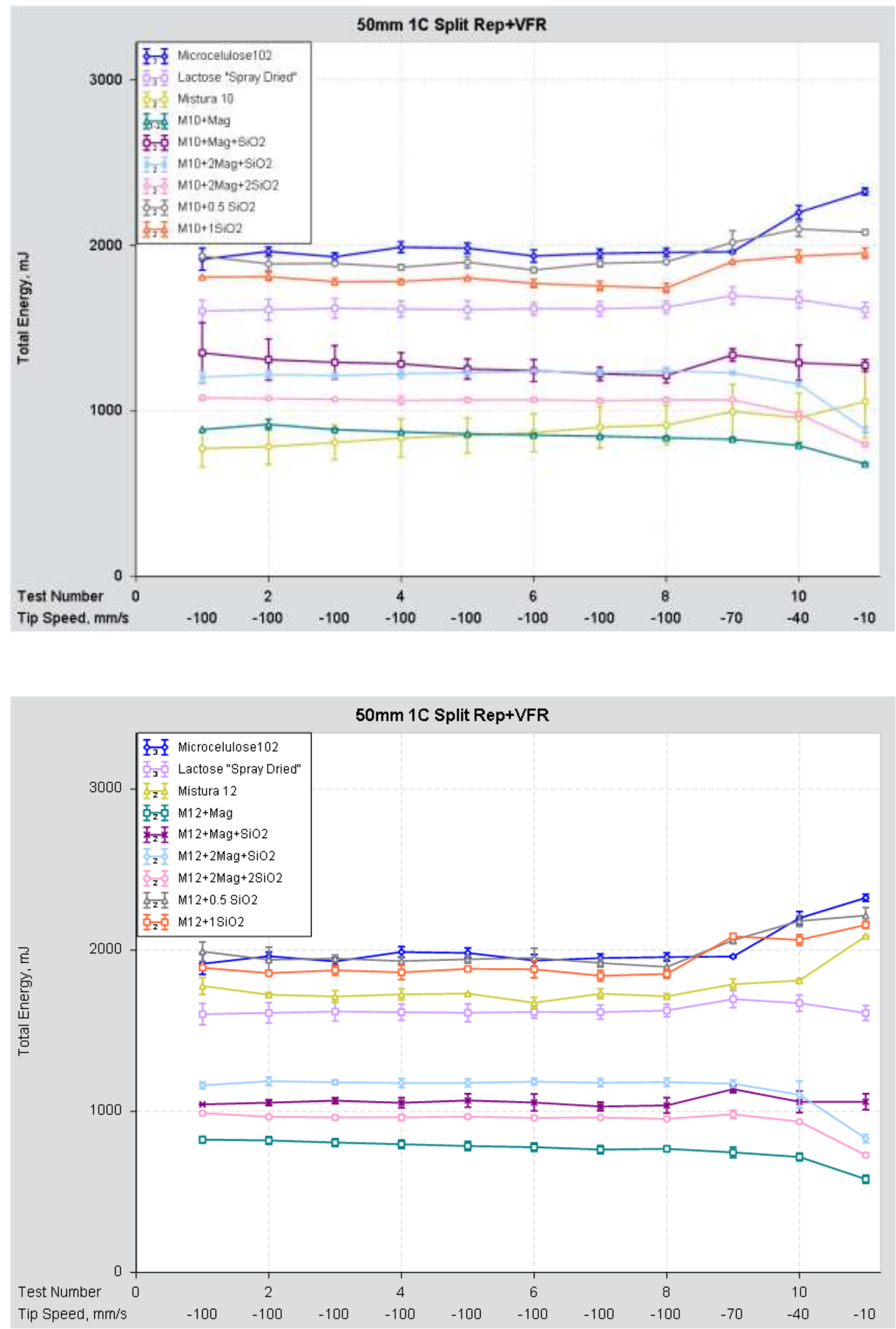
APÊNDICE D - Resultado do teste de Compressibilidade realizado com as pré-misturas de excipientes farmacêuticos 

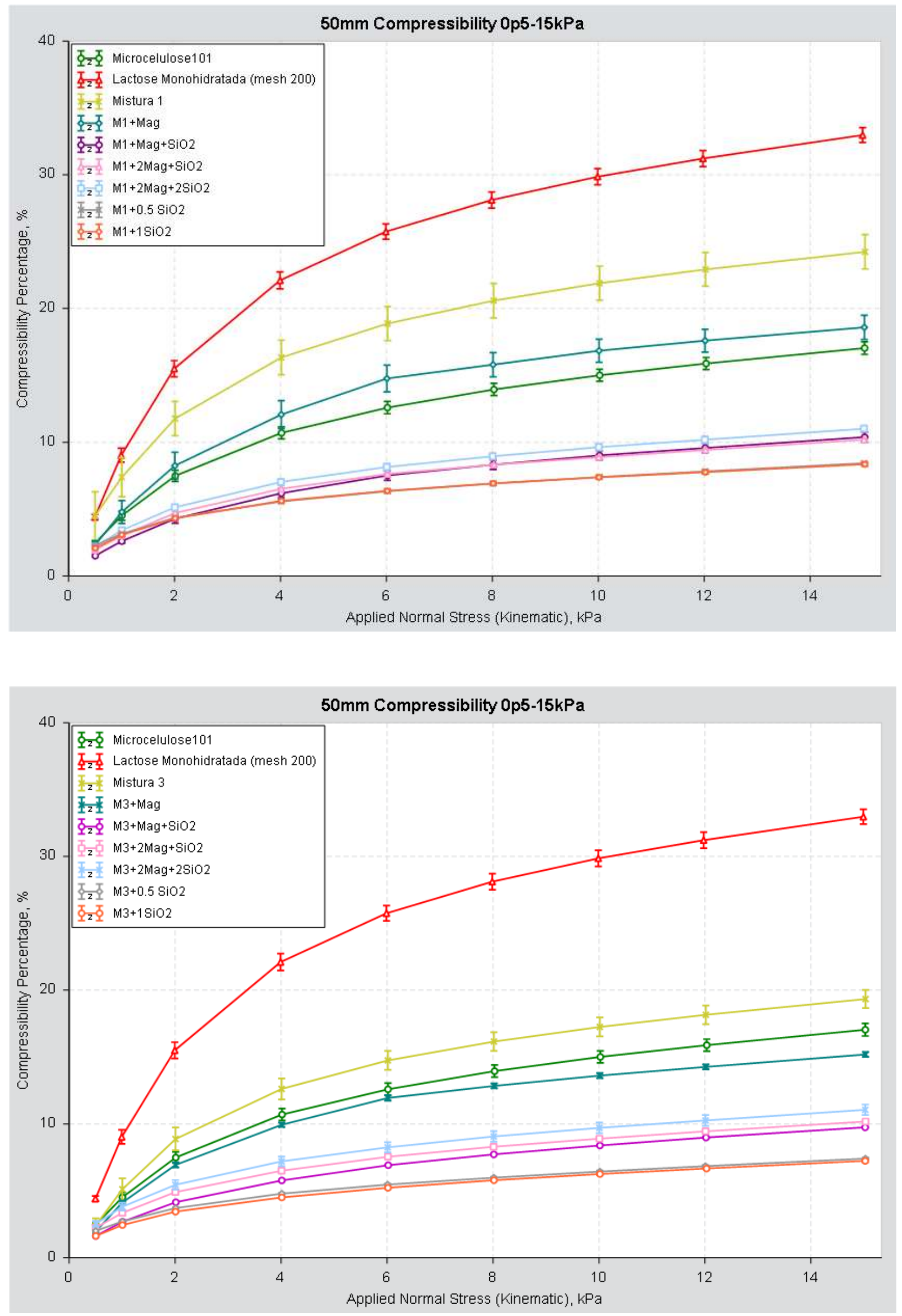

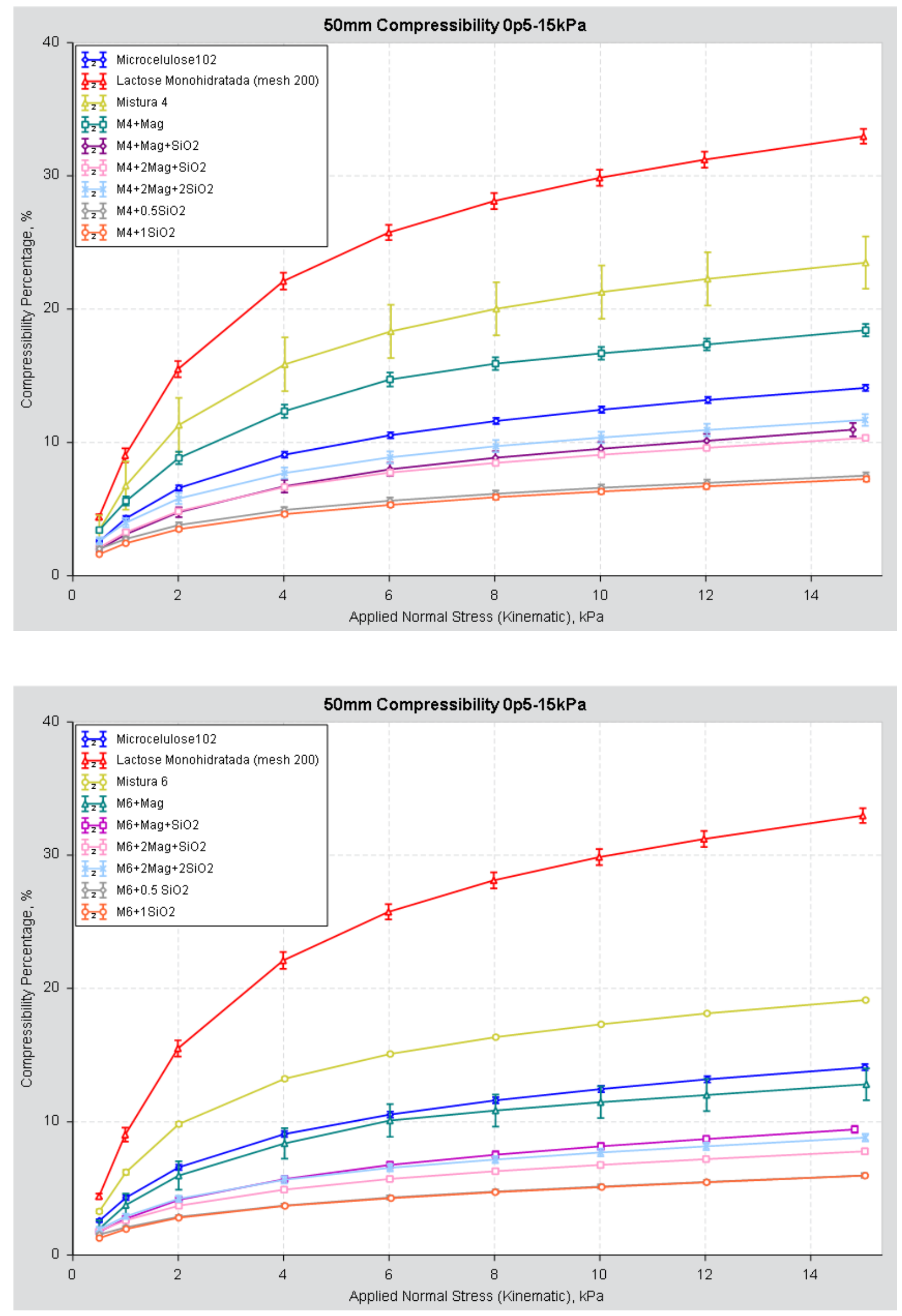

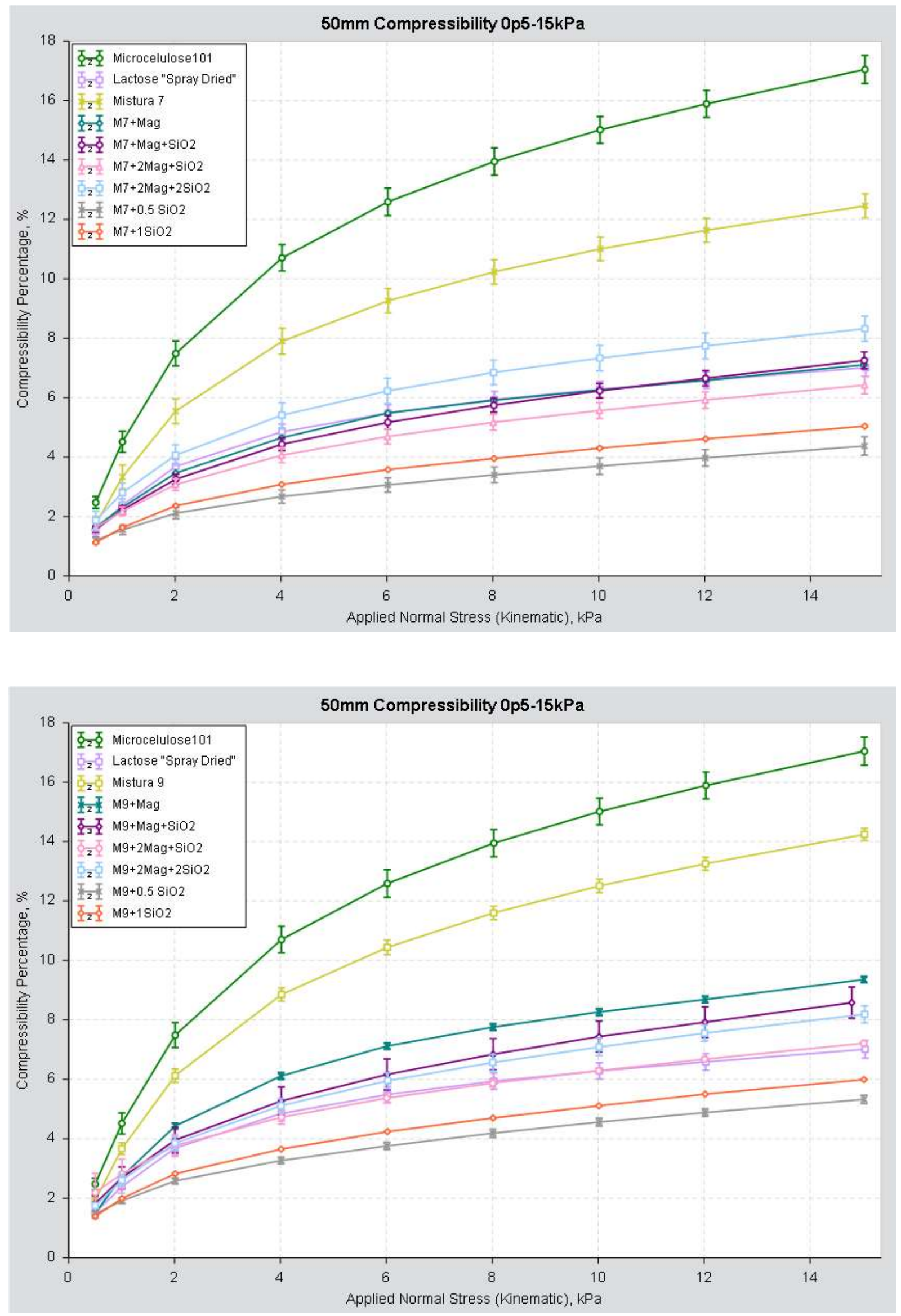
$50 \mathrm{~mm}$ Compressibility $0 \mathrm{p} 5-15 \mathrm{kPa}$

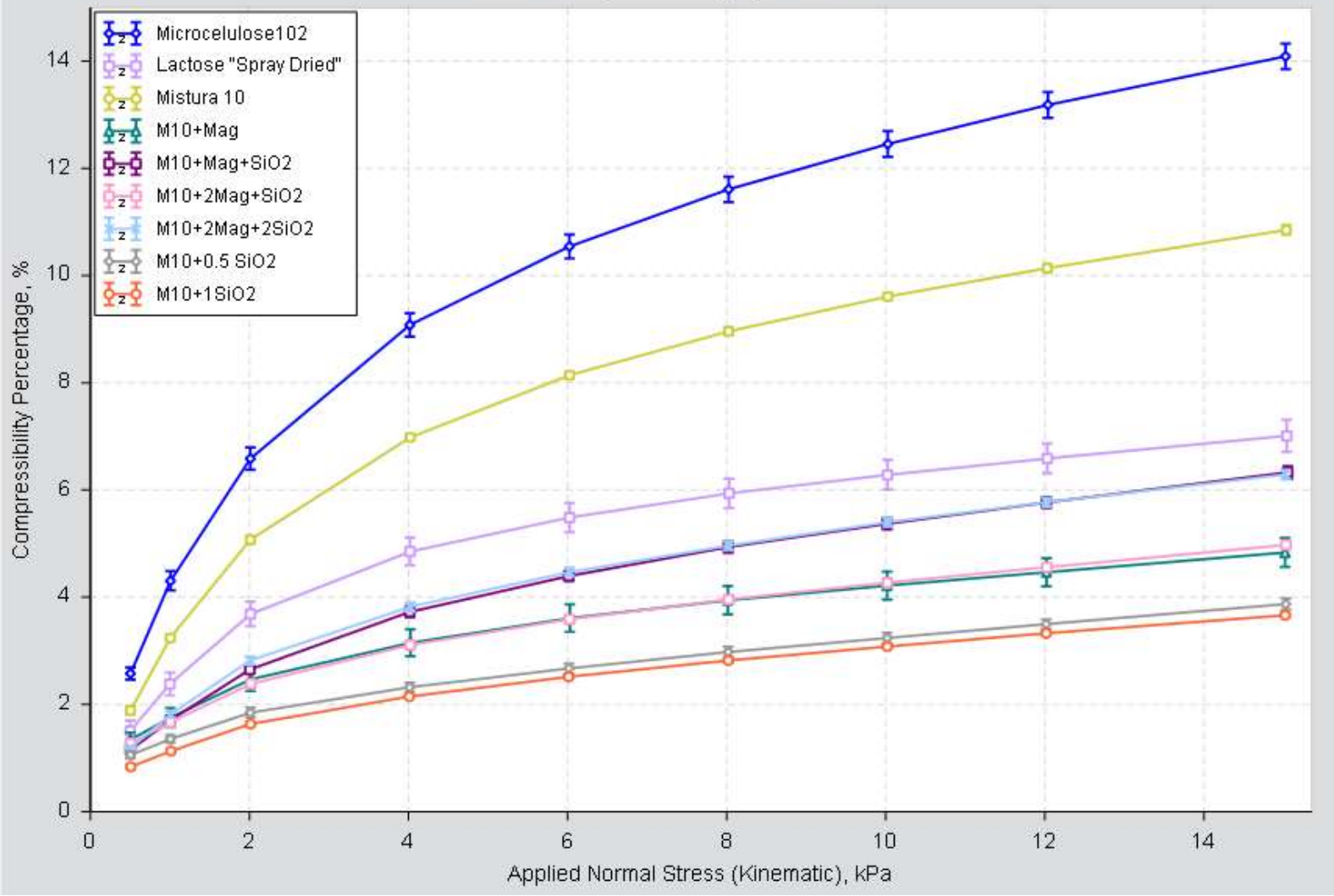

$50 \mathrm{~mm}$ Compressibility $0 \mathrm{p} 5-15 \mathrm{kPa}$

14

하조 Microcelulose102

z Lactose "Spray Dried"

2 Mistura 12

도퐁 M12+Mag

12 - $\mathrm{M}_{12}+\mathrm{Mag}+\mathrm{SiO} 2$

$\mathrm{M} 12+2 \mathrm{Mag}+\mathrm{SiO} 2$

5. $\mathrm{M} 12+2 \mathrm{Mag}+2 \mathrm{SiO} 2$

$\therefore 10-$

告重 $\mathrm{M} 12+0.5 \mathrm{SiO} 2$

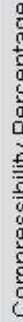

I. $\mathrm{M} 12+1 \mathrm{SiO} 2$
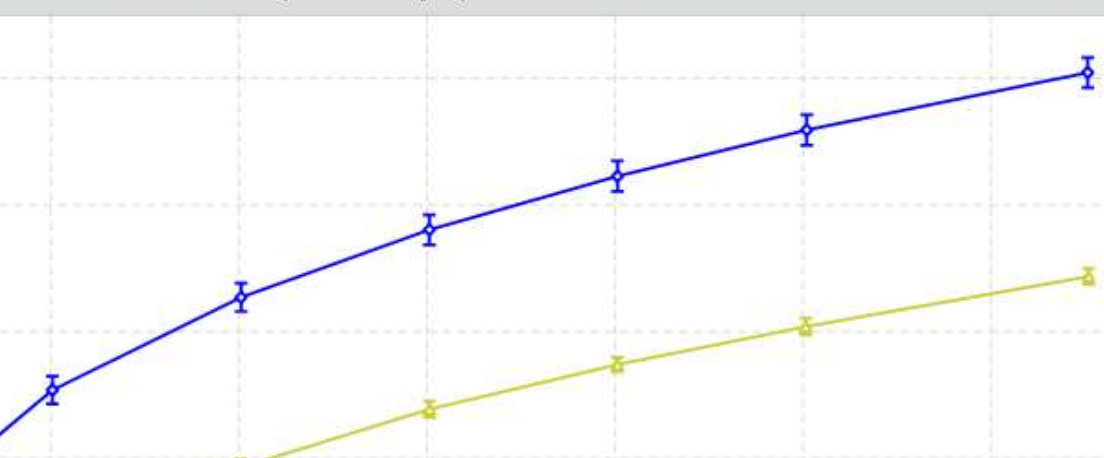
APÊNDICE E - Resultados do teste de Permeabilidade realizado com as pré-misturas de excipientes farmacêuticos 

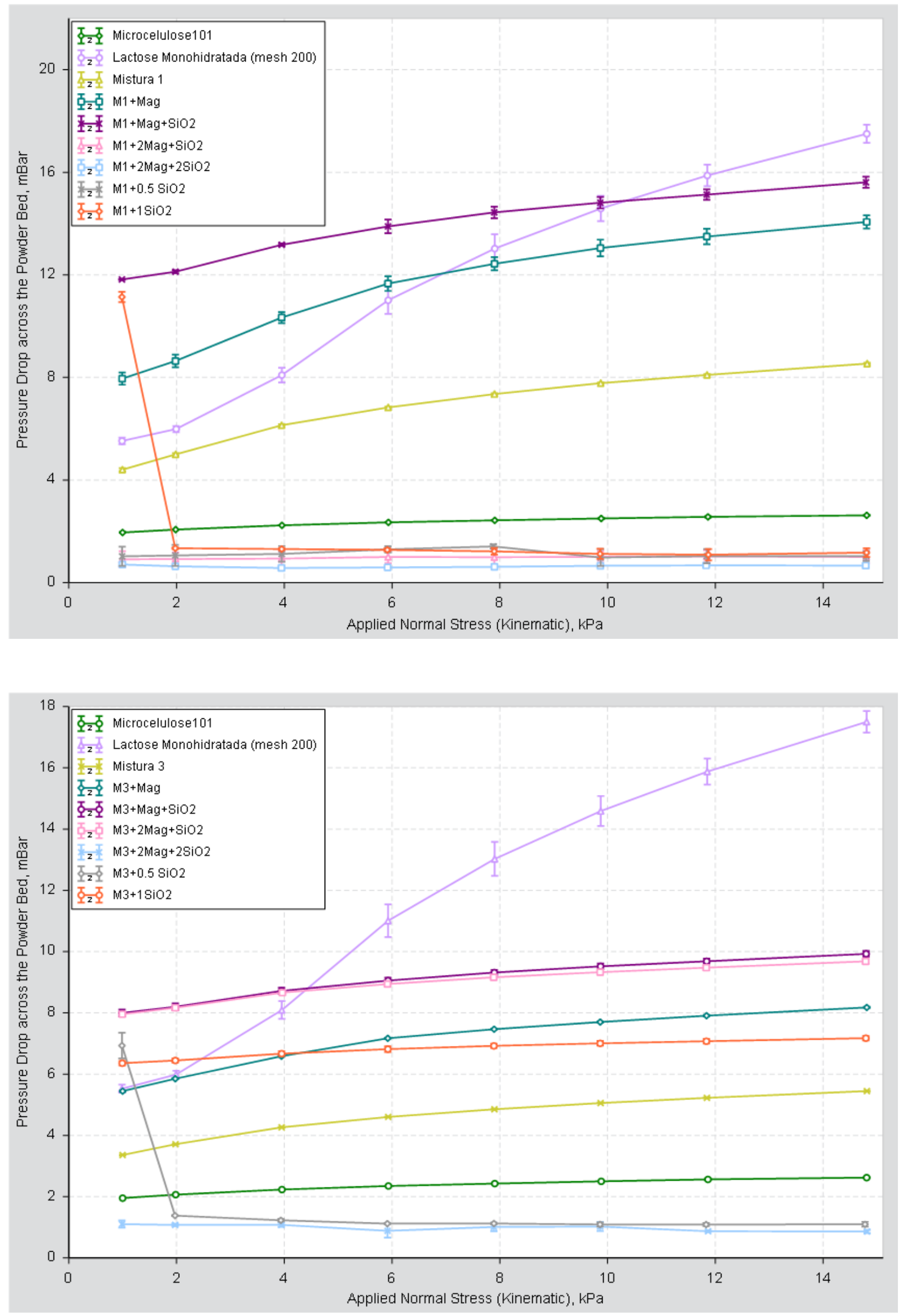

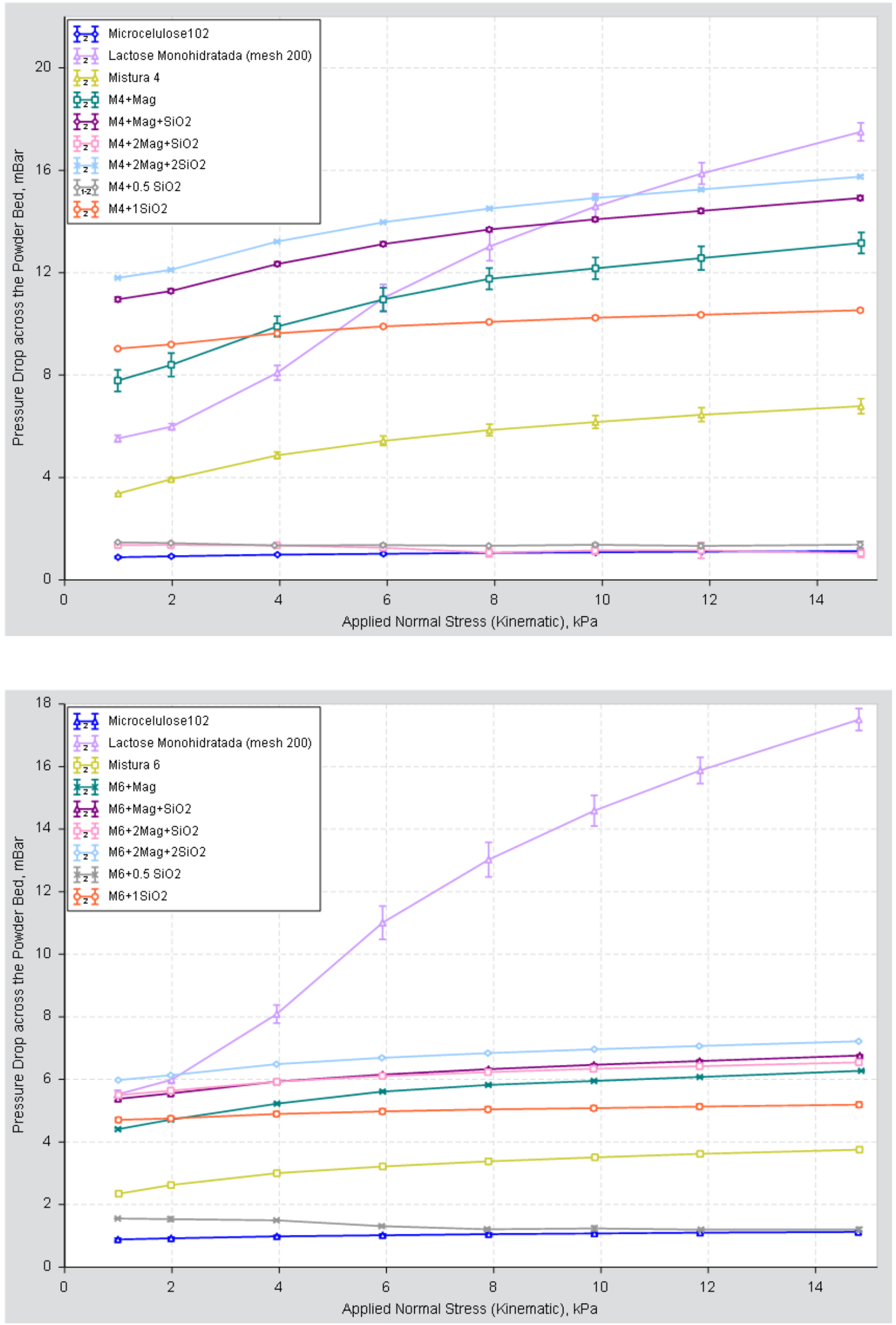

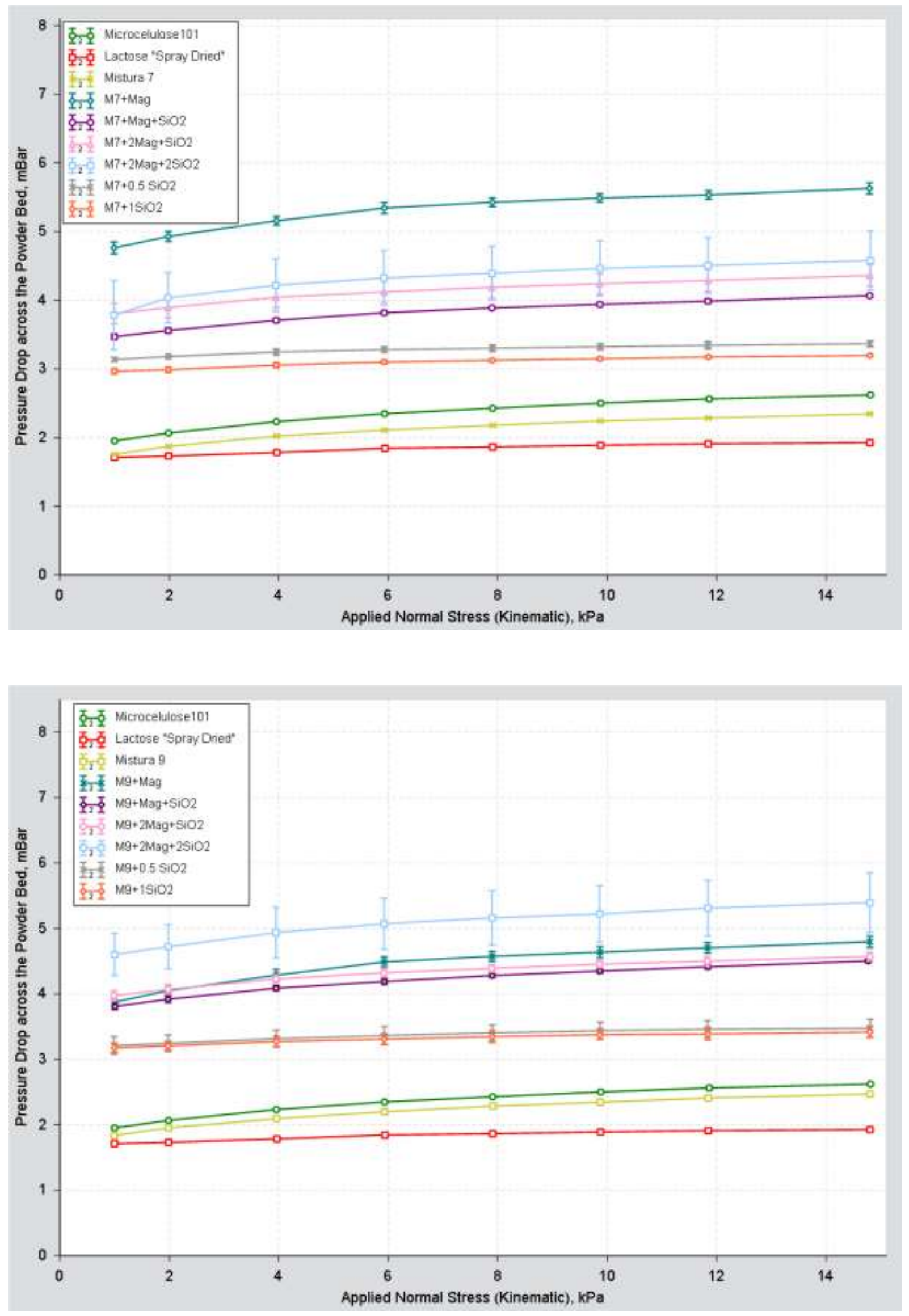

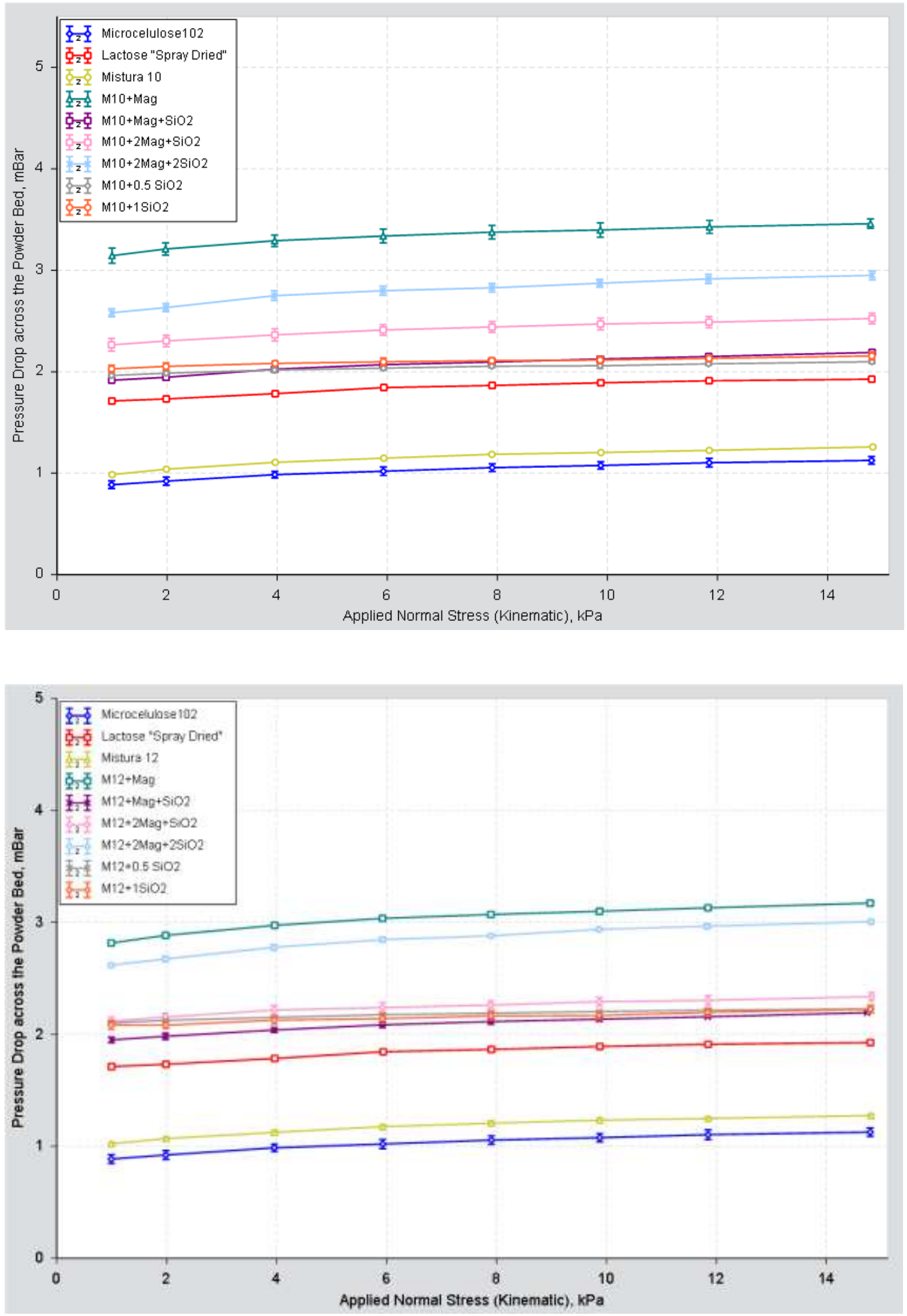
APÊNDICE F - Resultados do teste de Aeração realizado com as pré-misturas de excipientes farmacêuticos 

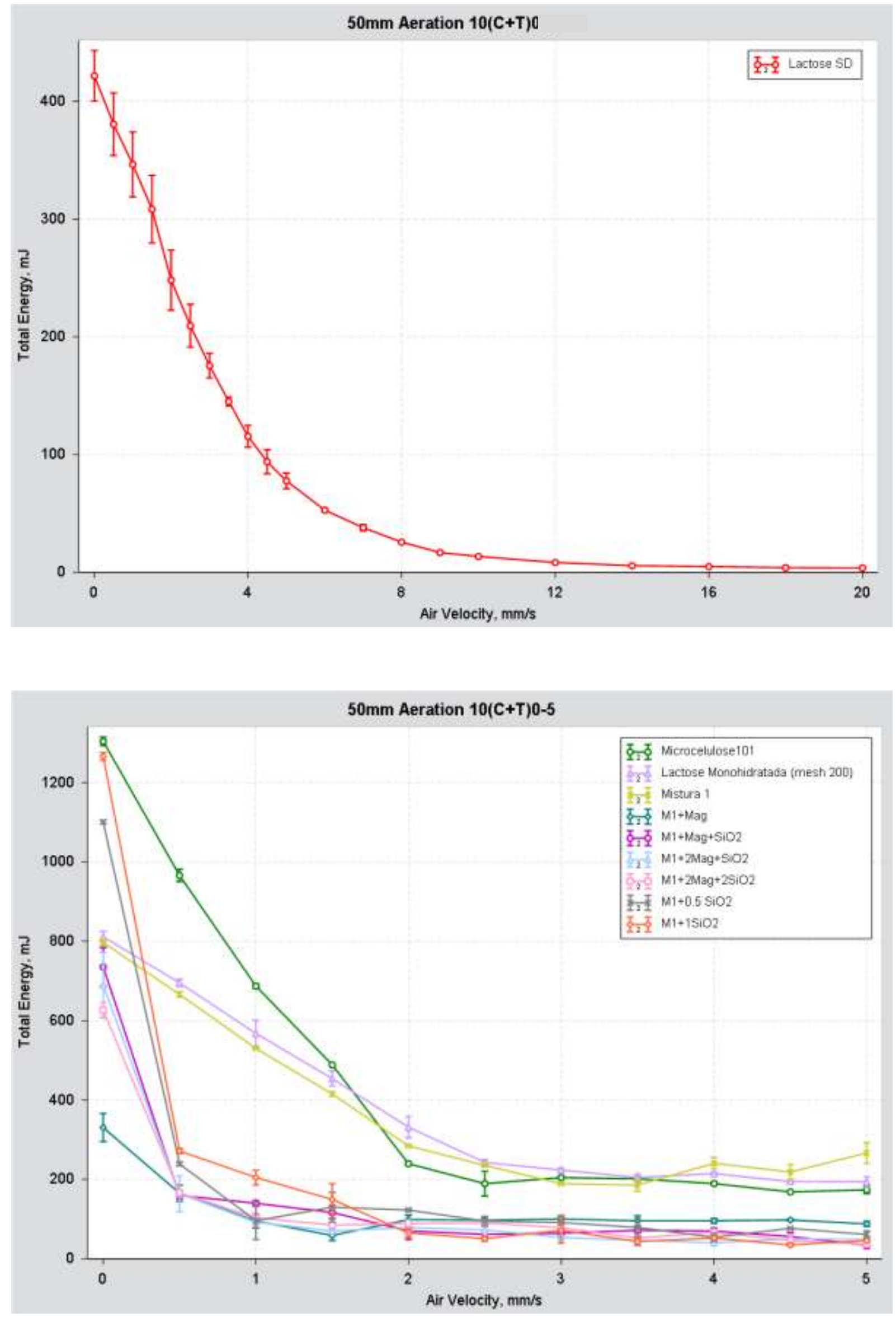

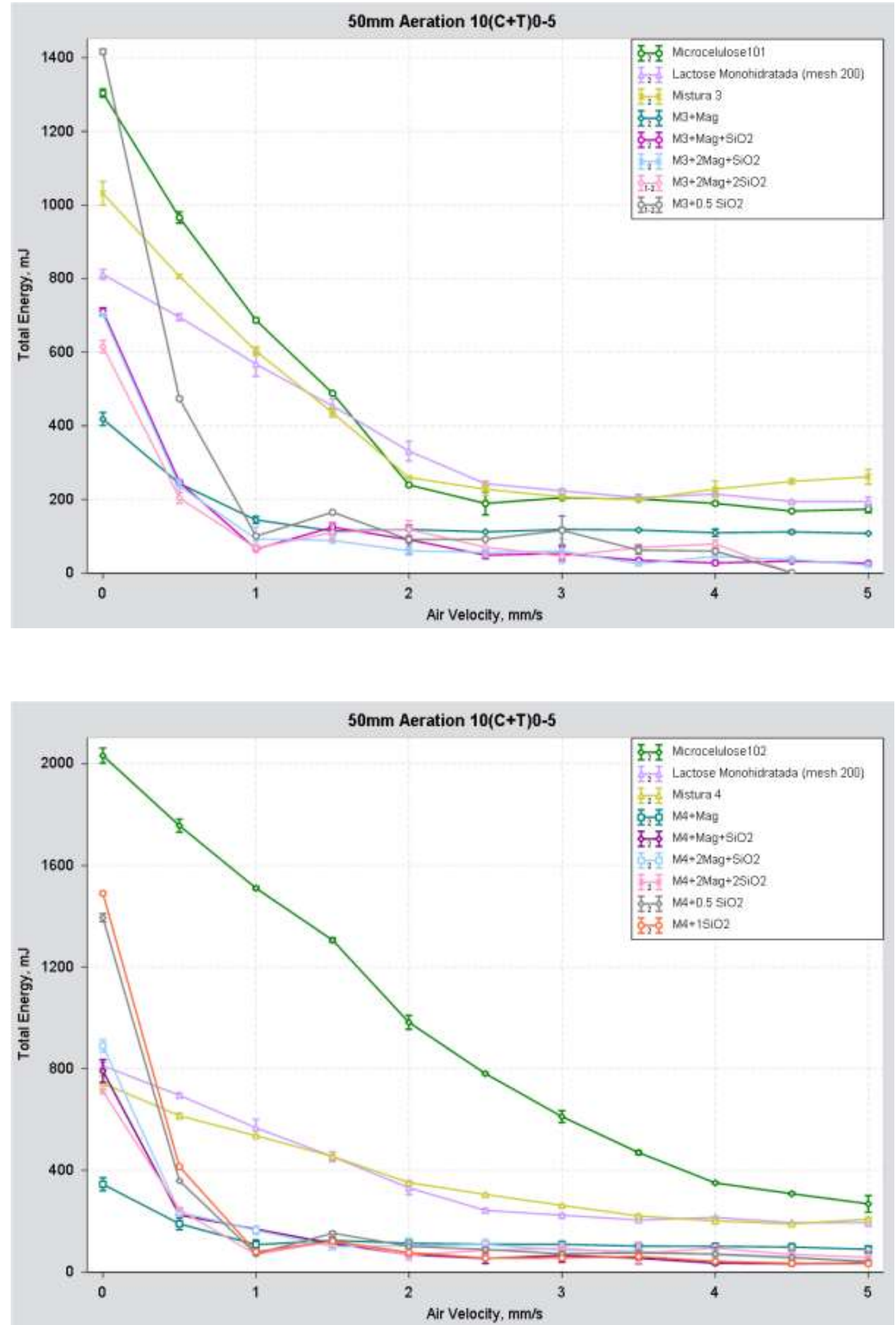

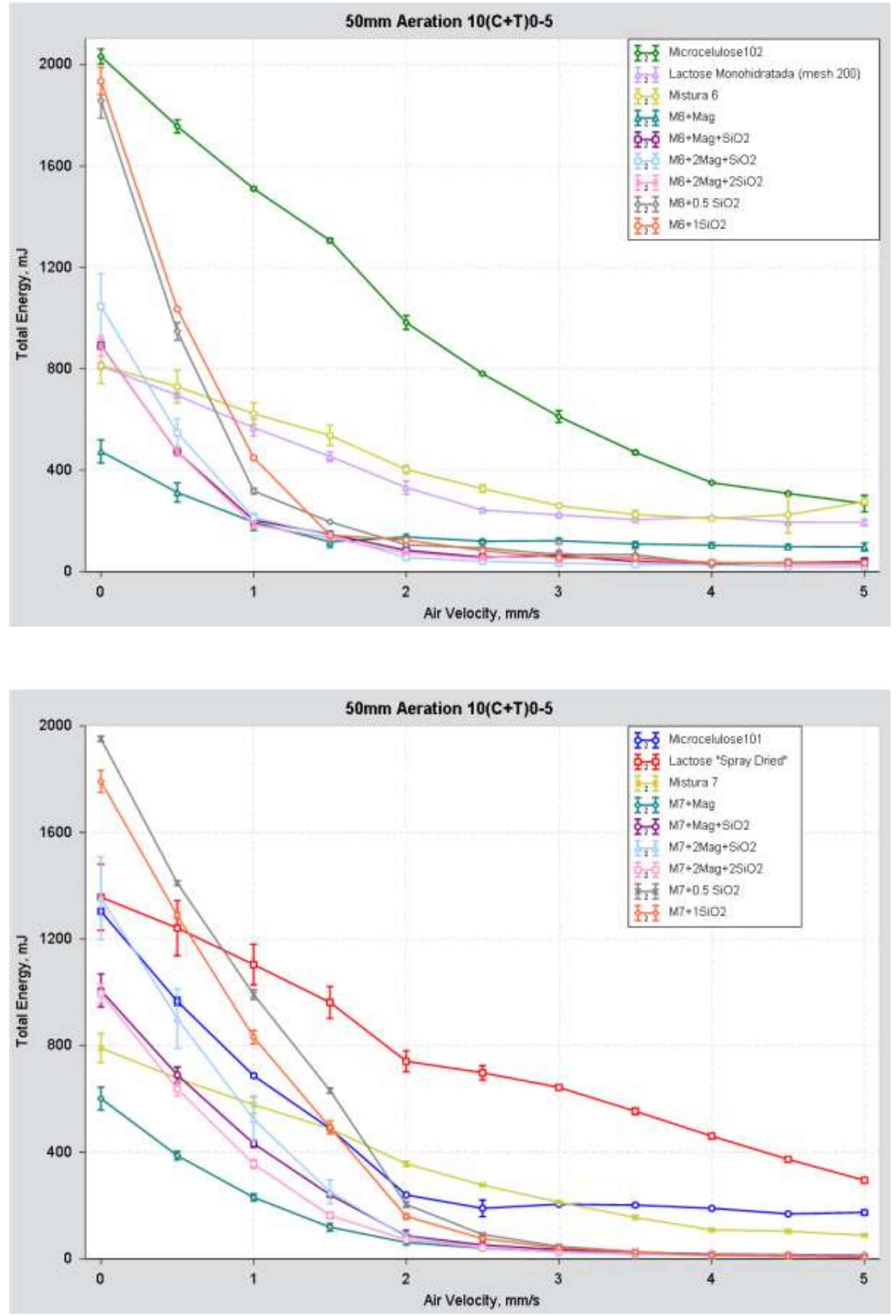

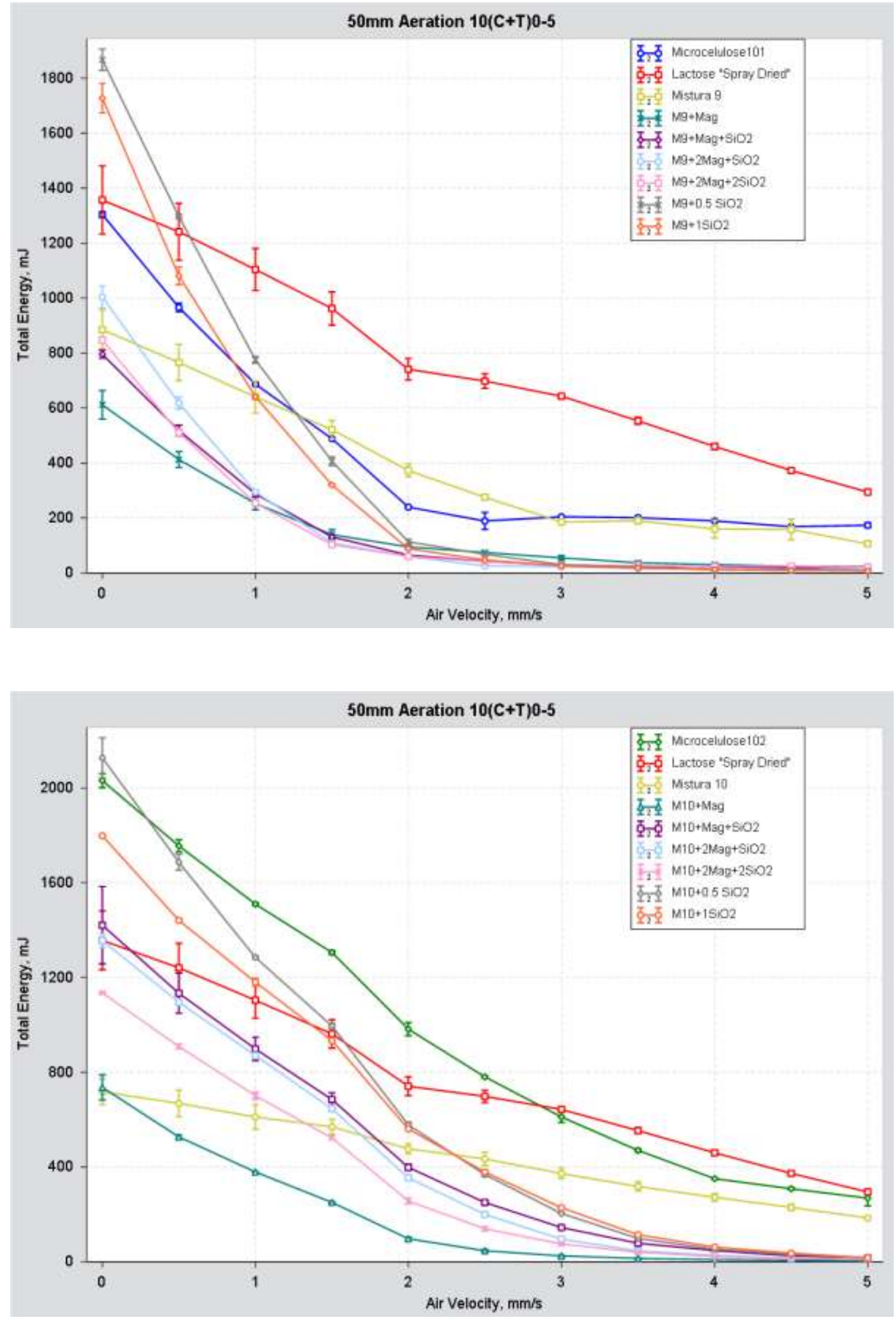


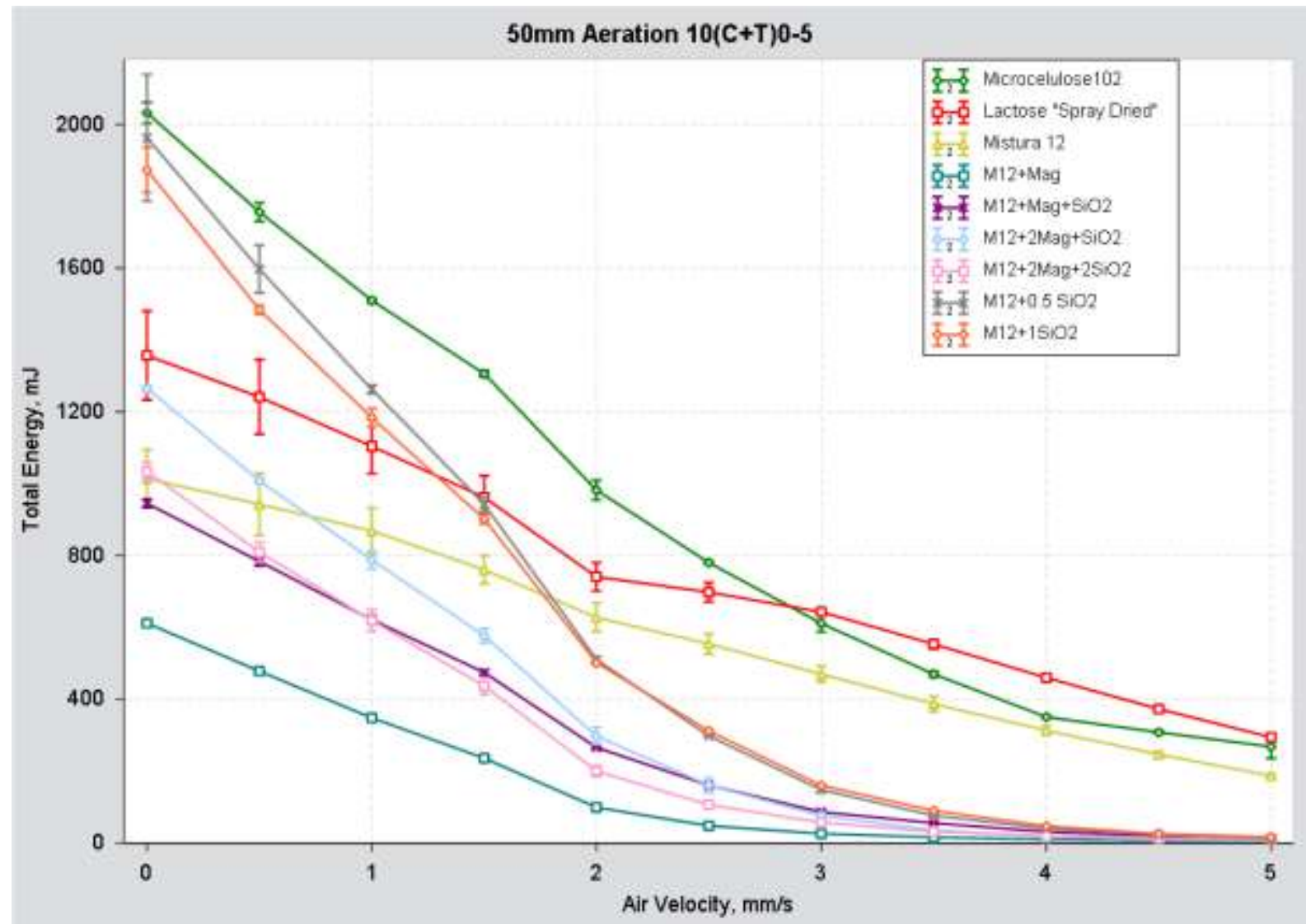


APÊNDICE G - Resultado do teste de Cisalhamento realizado com as pré-misturas de excipientes farmacêuticos, à 3,6 e $9 \mathrm{kPa}$ respectivamente 

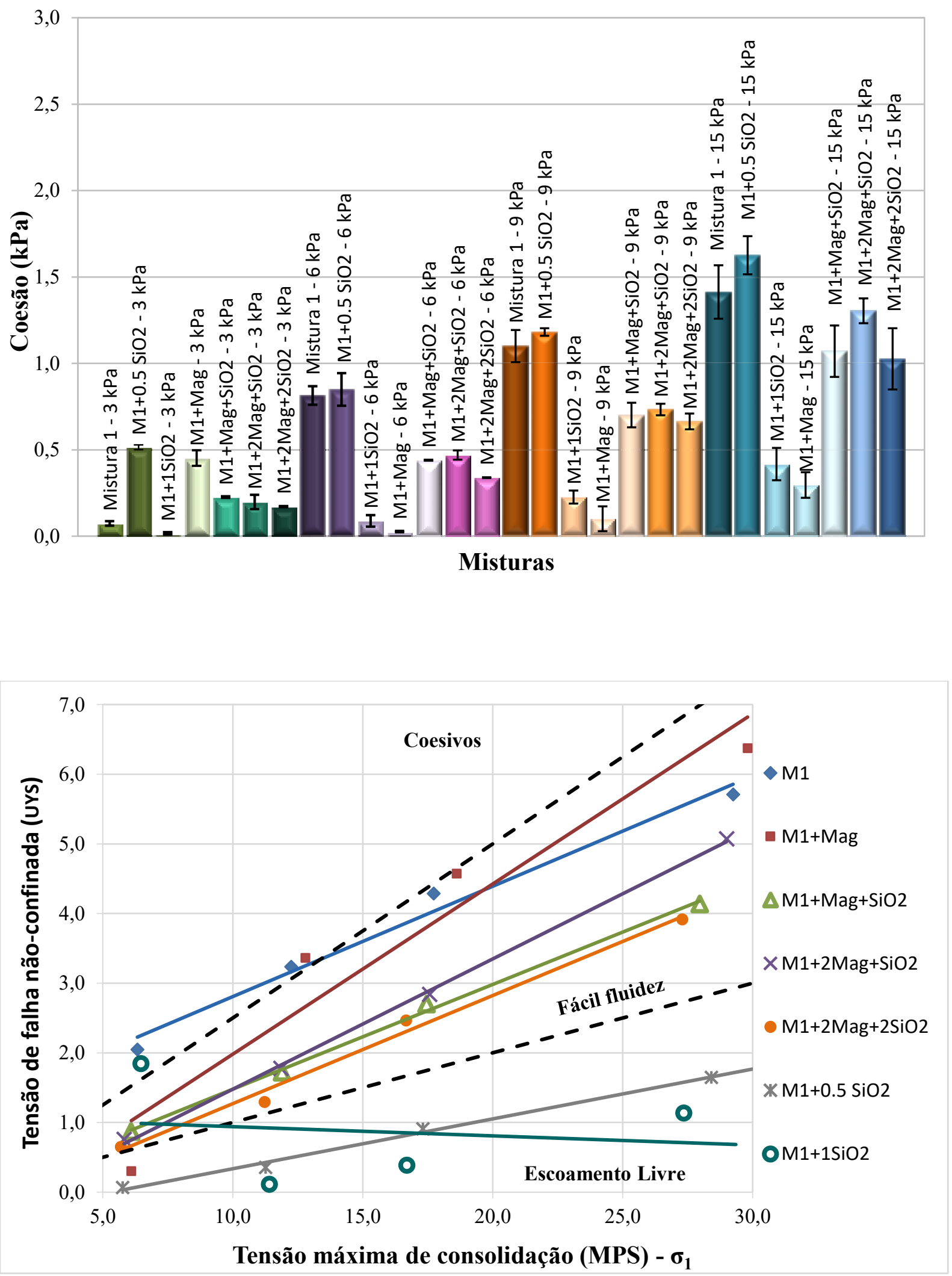

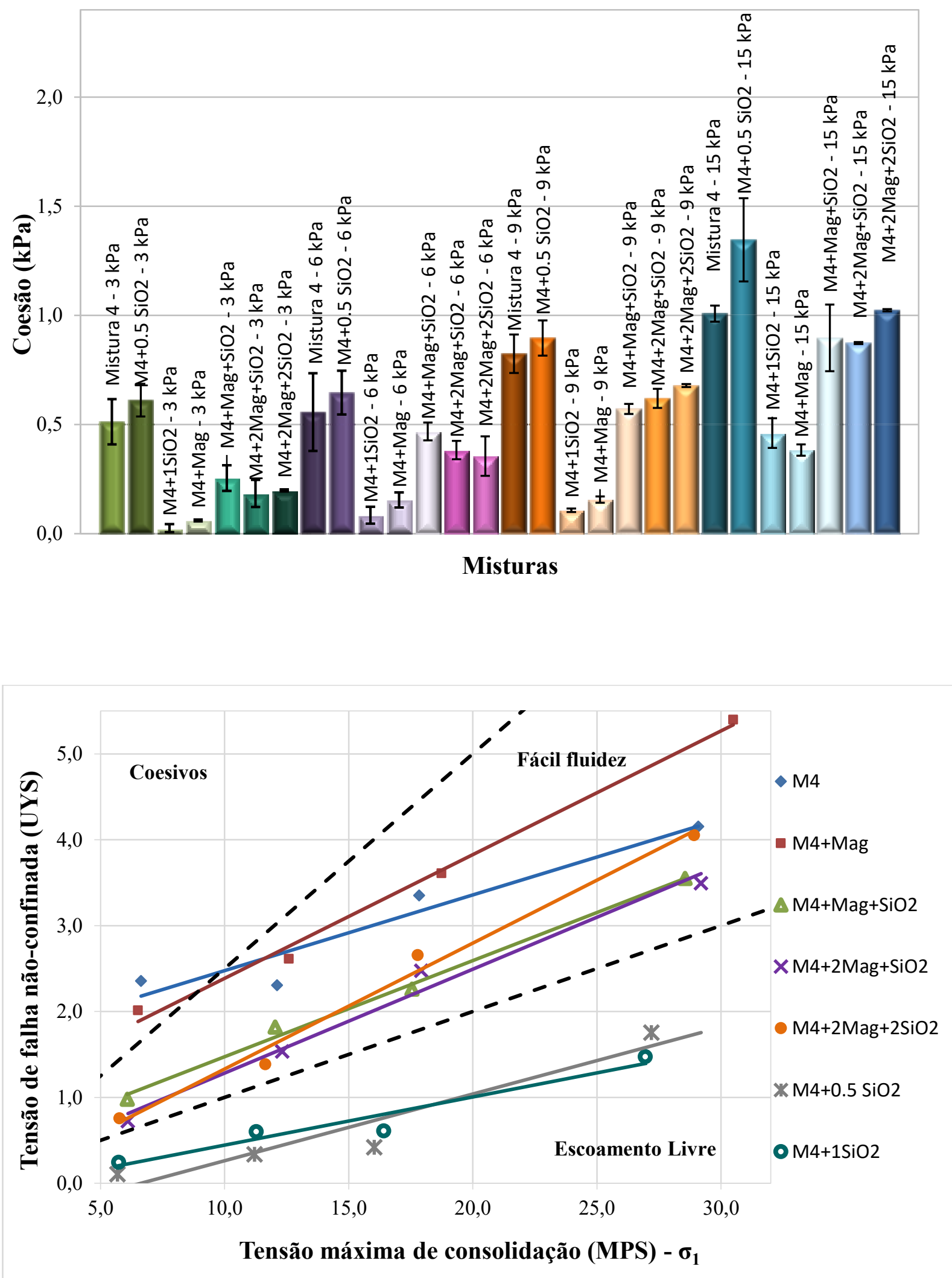

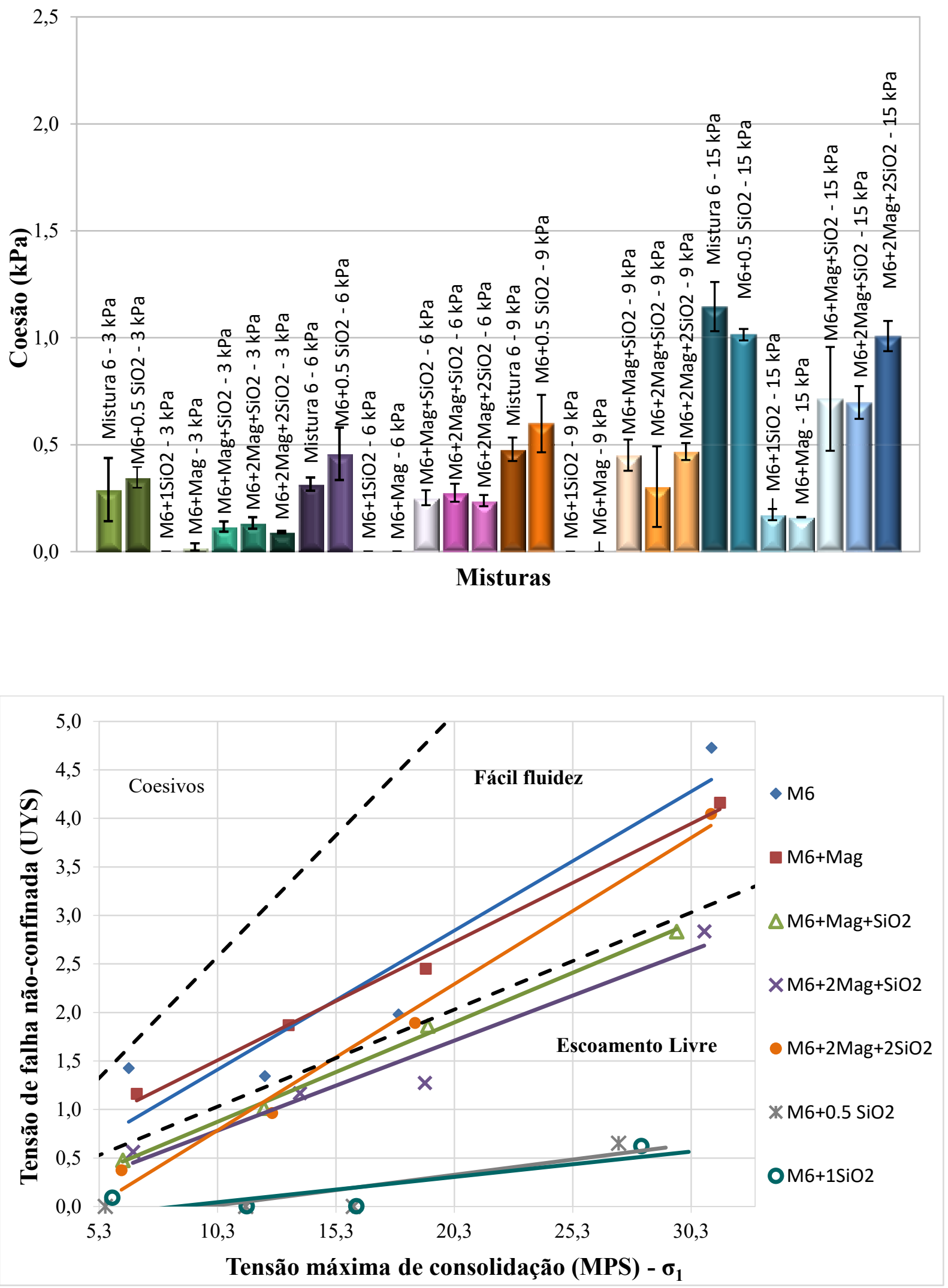

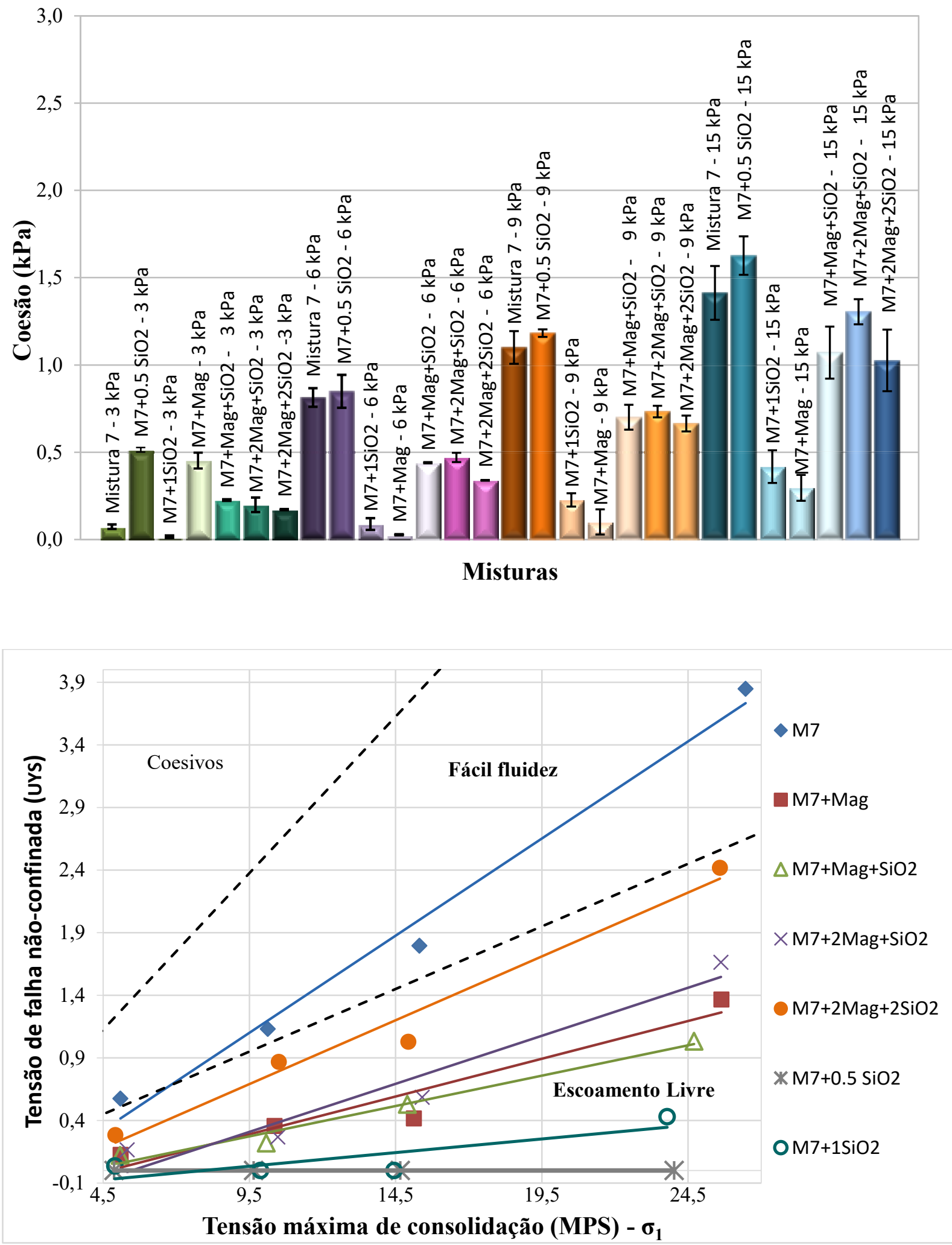

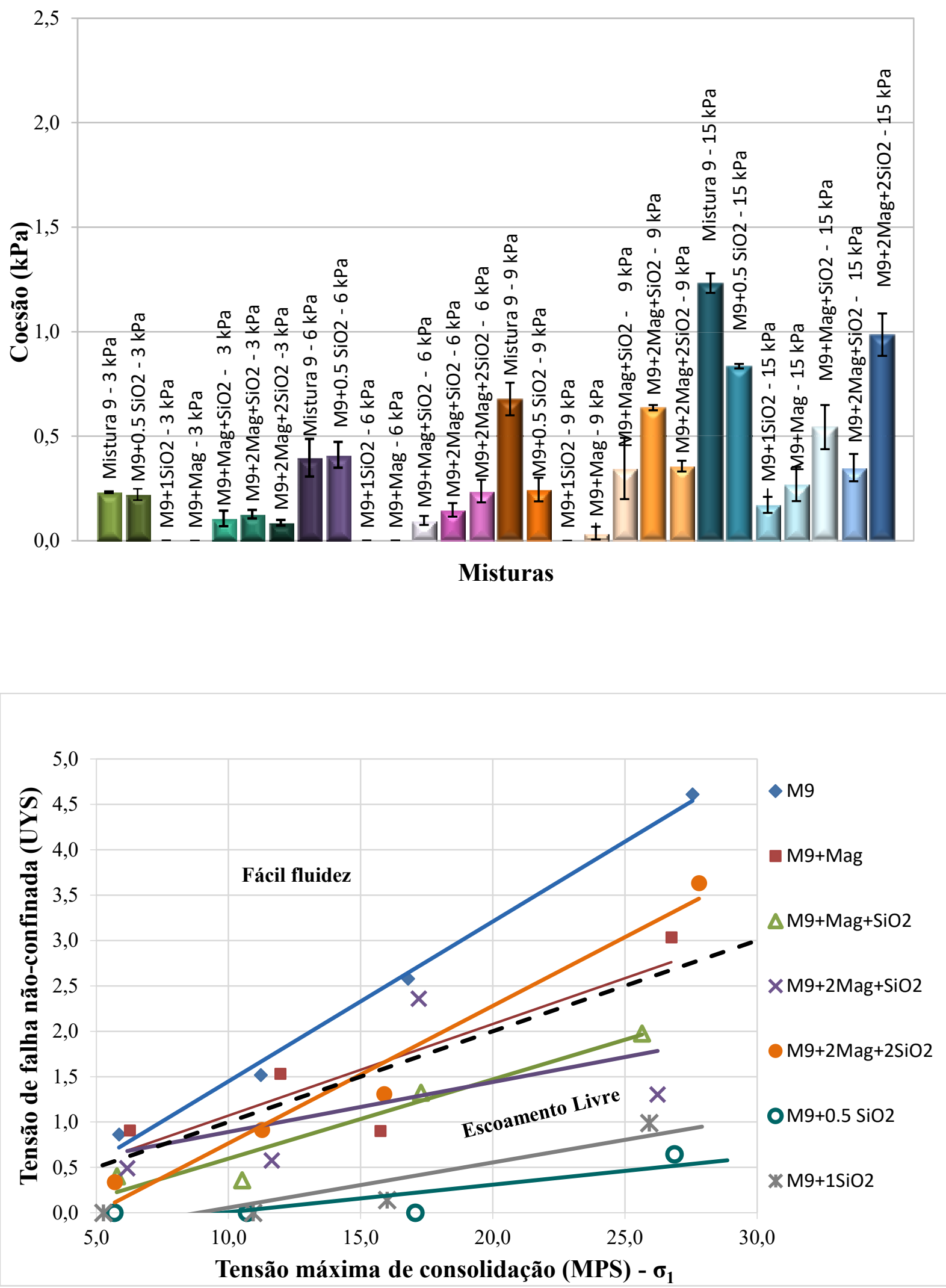



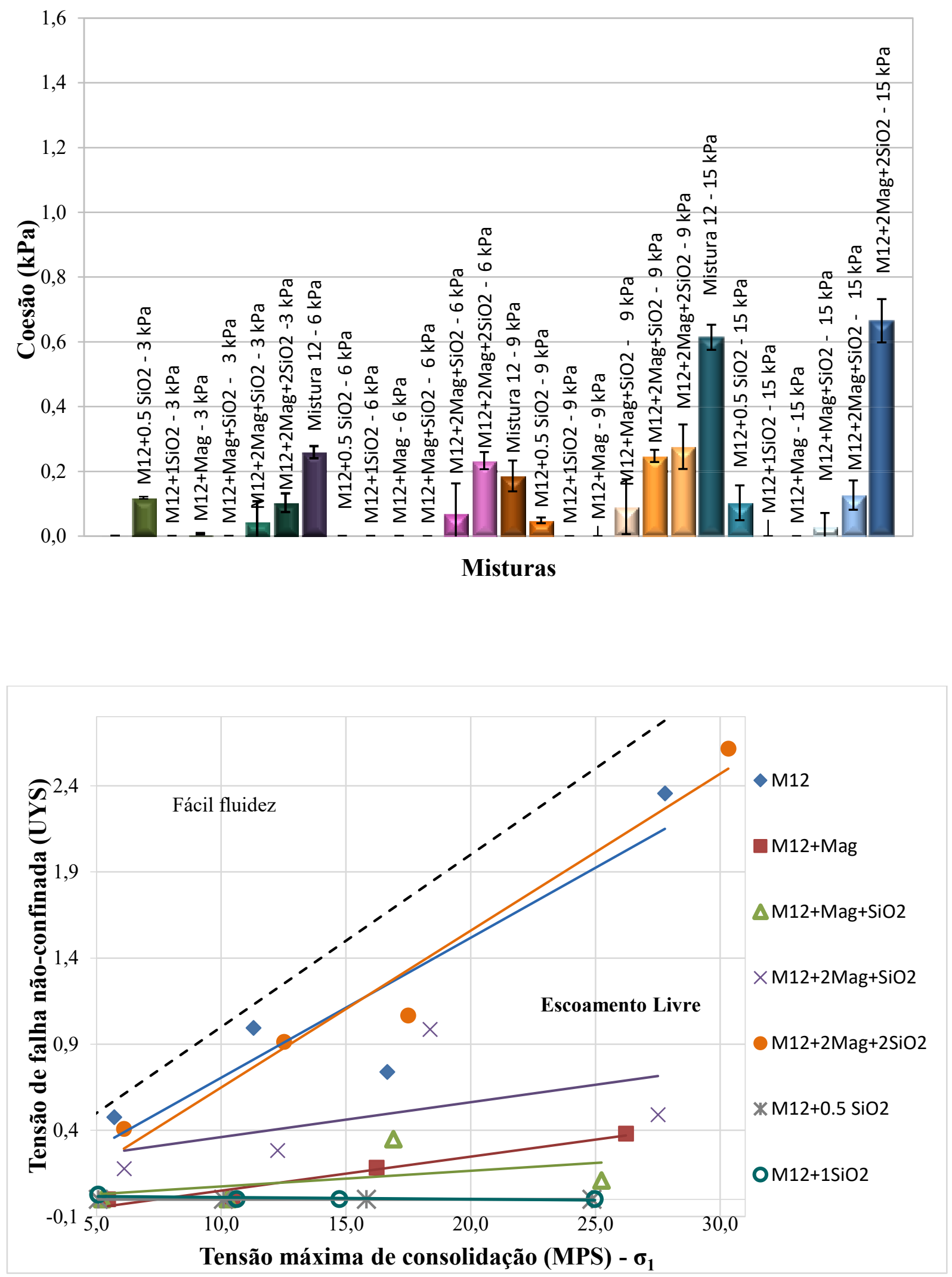
APÊNDICE H - Resultado da Área Superficial, do BFE e da Massa Específica das amostras que contêm o princípio ativo Efavirenz 


\begin{tabular}{|c|c|c|c|c|c|c|}
\hline \multirow{2}{*}{ Amostra } & \multirow{2}{*}{ Análise } & \multirow{2}{*}{$\begin{array}{c}\text { Área } \\
\text { superficial } \\
\left(\mathrm{m}^{2} / \mathrm{g}\right)\end{array}$} & \multicolumn{3}{|c|}{ CDB $(\mathrm{g} / \mathrm{mL})$} & \multirow{2}{*}{$\begin{array}{c}\text { Preal } \\
(\mathrm{g} / \mathrm{mL})\end{array}$} \\
\hline & & & EF & Comp. & Perm. & \\
\hline \multirow{4}{*}{$\begin{array}{c}\text { MCOLEFV } \\
0414\end{array}$} & 1 & 1,65 & 0,6184 & 0,6110 & 0,6190 & 0,5754 \\
\hline & 2 & 1,89 & 0,6384 & 0,6170 & 0,6220 & 0,5732 \\
\hline & Média & 1,77 & 0,6284 & 0,6140 & 0,6205 & 0,5743 \\
\hline & $\mathrm{DP}$ & 0,17 & 0,0141 & 0,0042 & 0,0021 & 0,0016 \\
\hline \multirow{4}{*}{$\begin{array}{c}\text { MCOLEFV } \\
0514\end{array}$} & 1 & 2,88 & 0,4808 & 0,4810 & 0,4910 & 0,7465 \\
\hline & 2 & 2,43 & 0,4844 & 0,4900 & 0,4890 & 0,7545 \\
\hline & Média & 2,66 & 0,4826 & 0,4855 & 0,4900 & 0,7505 \\
\hline & DP & 0,00 & 0,0025 & 0,0064 & 0,0014 & 0,0057 \\
\hline \multirow{4}{*}{$\begin{array}{c}\text { MCOLEFV } \\
0715\end{array}$} & 1 & 2,45 & 0,4652 & 0,4900 & 0,5120 & 0,5435 \\
\hline & 2 & 2,82 & 0,4676 & 0,5100 & 0,4760 & 0,5462 \\
\hline & Média & 2,63 & 0,4664 & 0,5000 & 0,4940 & 0,5449 \\
\hline & $\mathrm{DP}$ & 0,26 & 0,0017 & 0,0141 & 0,0255 & 0,0019 \\
\hline \multirow{4}{*}{$\begin{array}{c}\text { MCOLEFV } \\
0115\end{array}$} & 1 & 2,84 & 0,4440 & 0,4450 & 0,4140 & 0,4729 \\
\hline & 2 & 2,77 & 0,4524 & 0,4530 & 0,4850 & 0,5467 \\
\hline & Média & 2,81 & 0,4482 & 0,4490 & 0,4495 & 0,5098 \\
\hline & DP & 0,05 & 0,0059 & 0,0057 & 0,0502 & 0,0522 \\
\hline \multirow{4}{*}{$\begin{array}{c}\text { MCOLEFV } \\
0614\end{array}$} & 1 & 2,79 & 0,4696 & 0,4760 & 0,4830 & 0,6288 \\
\hline & 2 & 3,11 & 0,4720 & 0,4880 & 0,4600 & 0,5995 \\
\hline & Média & 2,95 & 0,4708 & 0,4820 & 0,4715 & 0,6142 \\
\hline & DP & 0,23 & 0,0017 & 0,0085 & 0,0163 & 0,0207 \\
\hline
\end{tabular}

